\title{
RESOURCE CONSERVATION AND RECOVERY ACT (RCRA) PART B PERMIT APPLICATION FOR PRODUCTION ASSOCIATED UNITS AT THE OAK RIDGE Y-12 PLANT
}

Building 9206 Container Storage Unit Building 9212 Container Storage Unit Building 9720-12 Container Storage Unit Cyanide Treatment Unit

Environmental Management Department

Health, Safety, Environment, and Accountability Organization

September 1994

Prepared by

Oak Ridge Y-12 Planı

Oak Ridge, Tennessee 37831

Managed by MARTIN MARIETTA ENERGY SYSTEMS, INC. for the U.S. DEPARTMENT OF ENERGY under contract DE-AC05-84QR21400 


\section{OISCLAIMER}

This report was prepared as an account of work sponsored by an agency of the United Stotes Government. Neither the United States Government nor any agency thereof, nor any of their employees, makes any marranty, expurass or implied, or assumes any legal liability or responsibility for the accuracy, completeness, or usefulness of any information, apparatus, product, or process disclosed, or represents that its use would not infringe privately owned rights. Reference hersin to any specific commercial product, process, or service by trade name, trademark, manufacture, or othervise, does not necessarily constitute or imply its endorsement. recommendation, or favoring by the United States Government or any agency thereof. The views and opinions of authors axpressed herein do not necessarily state or reflect those of the United States Government or any agency thereof. 


\title{
RESOURCE CONSERVATION AND RECOVERY ACT (RCRA) PART B PERMIT APPLICATION FOR PRODUCTION ASSOCIATED UNITS AT THE OAK RIDGE Y-12 PLANT
}

\author{
Building 9206 Container Storage Unit \\ Building 9212 Container Storage Unit \\ Building 9720-12 Container Storage Unit \\ Cyanide Treatment Unit
}

Environmental Management Department

Health, Safety, Environment, and Accountability Organization

\author{
Prepared by \\ Oak Ridge Y-12 Plant \\ Oak Ridge. Tennessee 37831 \\ Managed by \\ MARTIN MARIETTA ENERGY SYSTEMS, INC. \\ for the \\ U.S. DEPARTMENT OF ENERGY \\ under contract DE-AC05-84OR 21400




\section{DISCLAIMER}

This report was prepared as an account of work sponsored by an agency of the United States Government. Neither the United States Government nor any agency thereof, nor any of their employees, make any warranty, express or implied, or assumes any legal liability or responsibility for the accuracy, completeness, or usefulness of any information, apparatus, product, or process disclosed, or represents that its use would not infringe privately owned rights. Reference herein to any specific commercial product, process, or service by trade name, trademark, manufacturer, or otherwise does not necessarily constitute or imply its endorsement, recommendation, or favoring by the United States Government or any agency thereof. The views and opinions of authors expressed herein do not necessarily state or reflect those of the United States Government or any agency thereof. 
September 22, 1994

Mr. R. J. Spence

Department of Energy, Oak Ridge Operations

Post Office Box 2001

Oak Ridge, Tennessee 37831

Dear Mr. Spence:

Notice of Deficiency (NOD) Response-Resource Conservation and Recovery Act (RCRA) Part B Permit Application for the Production Associated Units at the Oak Ridge Y-12 Plant

In reference to the letters dated July 14, 1994, "Notice of Deficiency, RCRA Part B Permit Application," and August 30, 1994, "Notice of Deficiency--Response Extension, RCRA Part B Permit Application," from the Tennessee Department of Environment and Conservation (TDEC) personnel, Enclosure 1 is a summary of the responses of the $\mathrm{X}-12$ Plant personnel to each of the TDEC comments listed in the subject NOD. Enclosure 2 is a revised and complete permit application entitled "Resource Conservation and Recovery Act Part B Permit Application for the Production Associated Units at the Oak Ridge Y-12 Plant," Document Y/TS-838/R3. Please note that changes made to the application are indicated in the right margin, except for the appendices which have been modified extensively.

Enclosure 3 is a computer disk containing the permit application as requested by TDEC personnel. As required in the NOD, please transmit four copies of Enclosures 1 and 2 (along with Enclosure 3) to the TDEC staff on or before October 1, 1994.

I certify that this document and all enclosures were prepared under my direction or supervision in accordance with a system designed to ensure that qualified personnel properly gathered and evaluated the information submitted. Based on my inquiry of the person or persons directly responsible for gathering the information, the information submitted is, to the best of my knowledge and belief, true, accurate, and complete.

Note that the required permit certification has been signed and is included in Section $\mathrm{N}$ of the enclosed application. 
Mr. R. J. Spence, DOE-ORO

Page 2

September 22, 1994

Please direct any questions or comments to B. E. Skaggs at (615) 241-2582.

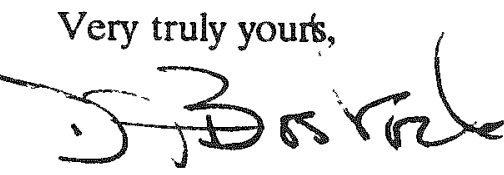

D. J. Bostock

Vice President and

Y-12 Plant Manager

Enclosures: As Stated

DJB:krl

cc/encs 1 \& 2: B. C. DeMonia, DOE-ORO

C. H. Fritts

J. A. Kreykes

A. K. Lee, DOE-OSTI (2)

L. G. Loden

A. G. Mitchell

T. P. A. Perry

B. E. Skaggs

Y-12 Central Files

File-EMD-RC

cc: D. J. Bostock

T. R. Butz/R. M. Keyser/J. E. Powell

G. N. Cobham

C. D. Goins Jr.

J. S. Guilford

C. C. Hill

N. C. Jessen

C. M. LaBorde

M. E. Mitchell

M. K. Morrow 
Enclosure 1

Letter, Bostock to Spence

Dated: September 22, 1994

\section{LETIER TTLLE}

Notice of Deficiency (NOD) Response--Resource Conservation and Recovery Act (RCRA) Part B Permit Application for the Production Associated Units at the Oak Ridge Y-12 Plant 


\author{
Notice of Deficiency \\ U.S. DOE Y-12 Plant \\ EPA ID: TN3 89-009-0001 \\ Part B Permit Application \\ Dated, May 1992
}

1. "40 CFR 270.14(b)(2) as incorporated by reference at Tennessee Rule 1200-1-11-.07(5)(a) requires a basis for the hazard designation the wastes in these facilities will receive. $A$ laboratory report on analysis results is also required. The application states, These data are considered classified for reasons of national security and can be made available for review by "Q" cleared regulatory personnel.' An employee with this clearance will review the hazard designation and the classified laboratory reports at a later date. Although ' $Q$ ' cleared personnel will review the classified information, all unclassified laboratory report results should be submitted along with your Part B application."

Response: Analytical data will be available to Q-cleared regulatory personnel. Typical unclassified analytical data is included in Appendix C-1.

2. "40 CFR 264.175(b) as incorporated by reference at Tennessee Rule 1200-1-11-.06(9)(a) requires the following information pertaining to basic design parameters, dimensions, and materials of construction:

1. Buildings 9206,9212 , and $9720-12$

a. Statement that the bases are free of cracks and gaps.

b. Engineering evaluation of structural integrity of base.

c. Discussion of compatibility of base with the wastes.

d. Demonstration of imperviousness of base to wastes and precipitation.

2. Cyanide Treatment Unit and Uranium Treatment Unit

a. Discussion of compatibility of base with wastes.

b. Engineering evaluation of structural integrity of base.

c. Demonstration of imperviousness of base to wastes and precipitation."

Response: A statement that the bases are free of cracks and gaps has been added to Section C, along with a discussion regarding the ability of the bases to support the wastes. Also added is a discussion regarding the impervious bases at each unit and a discussion of compatibility of bases with the wastes. The Uranium Treatment Unit has been deleted from the revised permit application; therefore, comments regarding this unit are no longer applicable. A closure plan is being prepared for the Uranium Treatment Unit.

3. "40 CFR 270.175(b)(3) as incorporated by reference at Tennessee Rule 1200-1-11-.06(9)(a) requires completed blueprints of all buildings and treatment units present in the Part $B$ application. These are needed to calculate the capacity of, and better evaluate the containment and treatment units." Note: The above citation appears to be incorrect. It is assumed that the correct citation is 40 CFR 264.175(b)(3). 
Response: The quoted citation does not require completed blueprints. Such drawings are not available. However, as requested in a telephone conversation with Ms. Jamie Burroughs of the Tennessee Department of Environment and Conservation, additional detail has been added to the plan drawings presented in Appendix $D$ to assist in the evaluation of the units.

4. "40 CFR 264.193(a)-(f) as incorporated by reference Tennessee Rule 1200-1-11-.06(10)(a) includes certain requirements for the plans and description of design, construction, and operation of the secondary containment system. These include:

1. Proof that the materials are compatible with the wastes in the tank system.

2. Show system has sufficient strength and thickness to prevent failure caused by any of the following:

a. pressure gradients (including static head and external hydrological forces).

b. physical contact with the wastes.

c. climatic conditions.

d. stress of daily operation (including stresses from nearby vehicular traffic).

3. Calculations to prove that it is placed on a foundation or base that is capable of providing support, resisting pressure gradients above and below the system, and preventing failure due to settlement, compression or uplift."

Response: This comment regarding tank systems is no longer applicable since the Uranium Treatment Unit has been removed from the revised permit application. A closure plan is being prepared for the Uranium Treatment Unit.

5. "40 CFR 264.193(d)-(e) as incorporated by reference Tennessee Rule 1200-1-11.06(10)(a) requires a statement indicating that the external liner system is free of cracks or gaps."

Response: This comment regarding tank systems is no longer applicable since the Uranium Treatment Unit has been removed from the revised permit application. A closure plan is being prepared for the Uranium Treatment Unit.

6. "40 CFR 264.193(f) as incorporated by reference Tennessee Rule 1200-1-11.06(10)(a) indicates secondary containment and leak detection requirements for ancillary equipment, including the following:

1. Materials of construction used to construct or line the system. Show that these materials are compatible with the wastes in the tank system. 
2. Calculations proving that the secondary containment system is placed on a foundation or base that is capable of providing support, resisting pressure gradients above and below the system, and preventing failure due to settlement, compression, or uplift.

3. Show that the system has sufficient strength and thickness to prevent failure caused by any of the following:

a. pressure gradients (including static head and external hydrological forces).

b. physical contact with the wastes.

c. climatic conditions.

d. stress of daily operation (including stresses from nearby vehicular traffic)."

Response: These comments regarding tank systems are no longer applicable since the Uranium Treatment Unit has been removed from the revised permit application. A closure plan is being prepared for this unit.

7. "40 CFR 264.195(c) as incorporated by reference Tennessee Rule 1200-1-11.06(10)(a) requires a schedule and procedure for inspecting a cathodic protection system if one is present at the facility. If one is not present at the facility please discuss why the cathodic protection system is not needed."

Response: These comments regarding tank systems are no longer applicable since the Uranium Treatment Unit has been removed from the revised permit application. A closure plan is being prepared for this unit.

8. "40 CFR 264.15(a)-(b) as incorporated by reference Tennessee Rule 1200-1-11.06(2)(a) specifies that certain equipment, if present at the facility, must be inspected on a regular basis, and must be included on an inspection schedule. These include:

1. Monitoring Equipment
a. hazardous gas detectors
b. temperature gauges
c. pH monitors

2. Safety and Emergency Equipment

a. decontamination equipment - including shovels, mops, empty drums, etc.

3. Operating and Structural Equipment

a. ventilation equipment."

Response: The inspection schedule and inspection logs have been updated to include the applicable items listed above. This updated information is located in Appendices F-1 and F-2 of the revised permit application. 
9. "40 CFR 264.15 as incorporated by reference Tennessee Rule 1200-1-11.06(2)(a) specifies requirements for tank system inspection. These include:

1. Must have a procedure for emptying a tank to allow entry and inspection when necessary to detect corrosion or erosion of tank sides and bottom.

2. Must confirm proper orientation of cathodic protection system (if present) within six months after installation and a least annually thereafter."

Response: These comments regarding tank systems are no longer applicable since the Uranium Treatment Unit has been removed from the revised permit application. A closure plan is being prepared for this unit.

10. "40 CFR 264.15(d) as incorporated by reference Tennessee Rule 1200-1-11.06(2)(a) specifies requirements for the inspection log. These include:

1. Container inspection $\log$

a. The area that is to be inspected must be clearly labeled on the log sheet.

b. The title 'Interim Status Facility' must be deleted.

c. The inspection log needs to have an 'observation' section and a 'date and nature of repairs and remedial action' section. For an example look at the inspection log for your tanks.

d. Please define all-weather surface in the standard that states, 'containers of waste shall be placed on an all-weather surface' (S-02).

e. Problems, besides those listed, relating to container structural integrity need to be addressed.

f. The standard which states, 'facility is being operated in accordance with current permit application' is too broad, please specify any additional types of problems to look for.

g. All items listed on the inspection schedule must also be present on the log. The items which need to be added to the inspection log include: Pallets, building integrity, sumps, and ramps. Also list problems regarding these items that should be looked for during the inspection.

2. Tank inspection log

a. All items listed on the inspection schedule must also be present on the log. The items which need to be added to the inspection log include sumps, tank level markings, debris and refuse, and ladders. Also list problems that should be looked for during the inspection.

b. Did the three blank spaces seen on the log hold any important information? If they did please send a copy of the inspection log minus the holes.

3. Other logs

a. Need inspection log for monitoring equipment.

b. Inspection log needed for security equipment.

c. Inspection log needed for safety and emergency equipment." 
Response: The inspection schedule and inspection logs have been revised to include the applicable items listed above. This updated information is located in Appendices F-1 and F-2 of the revised permit application.

11. "40 CFR 264.50 through 40 CFR 264.56 as incorporated by reference Tennessee Rule 1200-1-11.06(4)(a) requires that Section $G$, the contingency plan section, be self contained in one portion of the application. Appendixes G-1 through G-4 need to be merged into Section G."

Response: The contingency plan has been revised to be a self-contained document. This revised plan is included as part of the revised permit application.

BESkaggs:krl

September 19, 1994 
Enclosure 2

Letter, Bostock to Spence

Dated: September 22, 1994

\section{LETTER TITLE}

Notice of Deficiency (NOD) Response--Resource Conservation and Recovery Act (RCRA)

Part B Permit Application for the Production Associated Units at the Oak Ridge Y-12 Plant 


\section{TABLE OF CONTENTS}

Page No.

SECTION B - FACILITY DESCRIPTION . . . . . . . . . . . . . . . B-1

B-1 General Description ............................

B-2 Topographic Map ...........................

B-3 Location Information $\ldots \ldots \ldots \ldots \ldots \ldots \ldots \ldots \ldots \ldots \ldots$ B-5

B-4 Traffic Information $\ldots \ldots \ldots \ldots \ldots \ldots \ldots \ldots \ldots \ldots \ldots \ldots$

SECTION C - WASTE CHARACTERISTICS ................. C-1

C-1 Chemical and Physical Analysis ....................

C-2 Waste Analysis Plan ........................ C-6

C-3 Land Disposal Restrictions .................... C-13

SECTION D - PROCESS INFORMATION .................. D-1

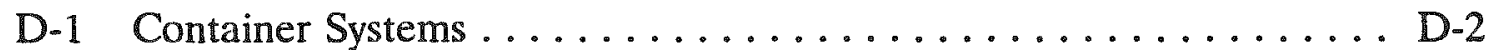

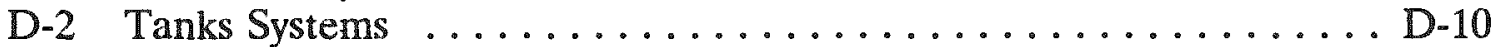

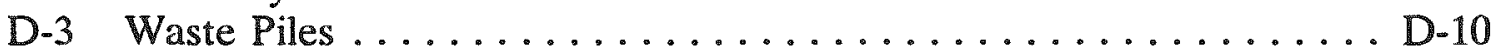

SECTION E - GROUNDWATER MONITORING ............... E-1

SECTION F - PROCEDURES TO PREVENT HAZARDS . . . . . . . . . . . F-1

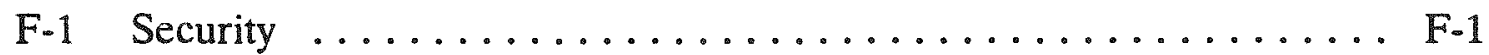

F-2 Inspection Schedule $\ldots \ldots \ldots \ldots \ldots \ldots \ldots \ldots \ldots \ldots \ldots$

F-3 Waiver of Preparedness and Prevention Requirements ......... F-6

F-4 Preventative Procedures, Structures and Equipment . . . . . . . . . F-7

F-5 Prevention of Reaction of Ignitable, Reactive, and Incompatible Wastes ......................F F-8

SECTION G - CONTINGENCY PLAN .................. 1

General Facility Description $\ldots \ldots \ldots \ldots \ldots \ldots \ldots \ldots \ldots$

General Information $\ldots \ldots \ldots \ldots \ldots \ldots \ldots \ldots \ldots$

Emergency Coordinators ....................... 2

Implementation .......................... 5

Control Procedures-Incident Commander ................. 5

Emergency Response Procedures--Emergency Coordinator ........ 6

Emergency Equipment ....................... 12

Coordination Agreements . . . . . . . . . . . . . . . . . 12

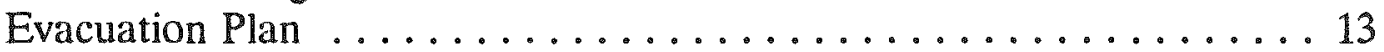

Required Reports .......................... 13 


\section{TABLE OF CONTENTS}

(Continued)

Page No.

SECTION H - PERSONNEL TRAINING .................

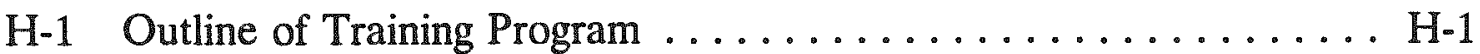

H-2 Implementation and Documentation of Training Program $\ldots \ldots \ldots$ H-6

SECTION I - CLOSURE PLAN, POST CLOSURE PLAN, AND FINANCIAL REQUIREMENTS . ............... I-1

I-1 Closure Plans . . . . . . . . . . . . . . . . . . . I 1

I-2 Post-Closure Plan ........................ I-6

I-3 Certifications and Notices Required For Closure . . . . . . . . I-7

I-4 Closure Cost Estimate ........................ I-8

I-5 Financial Assurance Mechanism For Closure ........... I-8

I-6 Post-Closure Cost Estimate . . . . . . . . . . . . . . . I-8

I-7 Financial Assurance Mechanism For Post-Closure . . . . . . . . I-8

I-8 Liability Requirements . . . . . . . . . . . . . . . I I-8

I-9 State Financial Mechanisms . . . . . . . . . . . . . . I

SECTION J - RECORDKEEPING $\ldots \ldots \ldots \ldots \ldots \ldots \ldots \ldots \ldots . \ldots \ldots$ J-1

J-1 Manifest Requirements . . . . . . . . . . . . . . .

$\mathrm{J}-2$ Operating Records $\ldots \ldots \ldots \ldots \ldots \ldots \ldots \ldots \ldots . . . \ldots \ldots$

SECTION K - OTHER FEDERAL LAWS $\ldots \ldots \ldots \ldots \ldots \ldots \ldots \ldots \ldots$

SECTION L - ORGANIC AIR EMISSIONS .............

SECTION M - SOLID WASTE MANAGEMENT UNITS $\ldots \ldots \ldots \ldots \ldots \ldots$ M-1

SECTION N - CERTIFICATION $\ldots \ldots \ldots \ldots \ldots \ldots \ldots \ldots \ldots \ldots \ldots \ldots \ldots \ldots$ 


\section{LIST OF FIGURES}

Figure No.

Page No.

B-1 Wind Rose from the West Meteorological Tower at 60 meters at the Y-12 Plant

B-2 Wind Rose from the East Meteorological Tower

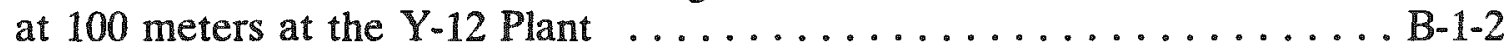

D-1 Building 9206, First Floor .......................

D-2 Building 9206, Second Floor . . . . . . . . . . . . . . D - $1-2$

D-3 Building 9206, Butler Building ..................

D-4 Building 9212, C-1 Wing, First Floor $\ldots \ldots \ldots \ldots \ldots \ldots \ldots \ldots \ldots$ D-1-4

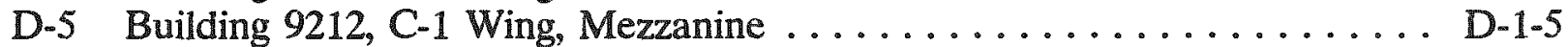

D-6 Building 9212 , Headhouse . . . . . . . . . . . . . . . D-1-6

D-7 Building 9212, Staging Area $\ldots \ldots \ldots \ldots \ldots \ldots \ldots \ldots \ldots \ldots \ldots \ldots \ldots \ldots .1-7$

D-8 Building 9720-12 Classified Container Storage Area . . . . . . . . . D-1-8

D-9 Building 9201-5N, Cyanide Treatment Unit . . . . . . . . . . D-1-9 


\section{LIST OF TABLES}

Table No.

Page No.

C-1 Typical Types of RCRA Wastes Stored and/or Treated ........... C-3

C-2 Typical Analytical Parameters for Treated Cyanide Solutions . . . . . . . . C-8

C-3 Test Methods for Production Associated Wastes . . . . . . . . . . . . C-9

C-4 Sampling Equipment for Particular Waste Types ............. C-10

F-1 General Inspection Schedule . ...................... .

F-2 Container Storage Area Inspection Schedule ............. F-1-2

F-3 Daily Inspection Log Sheet for Container Storage Areas . . . . . . . . . . F-2-1

F-4 Weekly Inspection Log Sheet for Container Storage Areas . . . . . . . F-2-2

I-1 Closure Schedule for the Production Associated Units . . . . . . . . . . I-4 


\title{
LIST OF APPENDICES
}

\author{
B-1 Maps \\ B-2 Wind Roses \\ C-1 Typical Waste Analysis Data \\ C-2 Waste Identification Forms \\ C-3 Examples of Potentially Incompatible Waste \\ D-1 Container Storage Design Details \\ F-1 General Inspection Schedule \\ F-2 Inspection Logs \\ H-1 Job Descriptions and Training Requirements
}




\section{LIST OF ACRONYMS}

CFR

COD

CWSA

DARA

DOE

DOT

EOC

EPA

HP

HSWA

IH

IRWTA

LDR

MMES

NaK

OJT

ORNL

ORR

OSHA

PED

PCB

PSS

RCRA

SARA

SID

TCLP

TDEC

TOC

UCN
Code of Federal Regulations

chemical oxygen demand

Containerized Waste Storage Area

Disposal Area Remedial Action

U.S. Department of Energy

U.S. Department of Transportation

Emergency Operations Center

U.S. Environmental Protection Agency

Health Physics

Hazardous and Solid Waste Amendments

Industrial Hygiene

Interim Reactive Waste Treatment Area

Land Disposal Restrictions

Martin Marietta Energy Systems, Inc.

sodium potassium

On-The-Job Training

Oak Ridge National Laboratory

Oak Ridge Reservation

Occupational Safety and Health Act

Plant Emergency Director

polychiorinated biphenyl

Plant Shift Superintendent

Resource Conservation and Recovery Act

Superfund Amendments Reauthorization Act

Stream Identification

Toxicity Characteristic Leaching Procedure

Tennessee Department of Environment and Conservation

total organic carbon

Uniform Control Number 


\section{SECTION B}

\section{FACILITY DESCRIPTION}

This section of the application provides a general description of the hazardous waste management facility as required by 40 CFR Part 270.14(b)(1) and Rules Governing Hazardous Waste Management in Tennessee, Rule 1200-1-11-.07(5)(a). This description is intended to provide guidance and facility orientation to the permit application reviewer and the permit writer for the Oak Ridge Y-12 Plant.

\section{B-1 GENERAL DESCRIPTION}

The Oak Ridge Y-12 Plant was built by the U.S. Army Corps of Engineers in 1943 as part of the Manhattan Project and was given the original mission to separate the fissionable isotope of uranium by the electromagnetic process. After World War II, the electromagnetic separation process was discontinued in favor of the more economical gaseous diffusion process. In recent years the Y-12 Plant staff has developed this facility into a highly sophisticated manufacturing and developmental engineering organization.

The U.S. Department of Energy (DOE) owns and operates the Y-12 Plant. Personnel from Martin Marietta Energy Systems, Inc., (Energy Systems) co-operate and manage the Y-12 Plant. Since 1984, the facility has been managed by Energy Systems personnel under a prime contract with DOE. The contract is administered by personnel at the DOE, Oak Ridge Operations Office.

The Y-12 Plant occupies approximately 800 acres in Anderson County, Tennessee, and is located southwest of the City of Oak Ridge. The site employs approximately 4,000 people including employees of the Oak Ridge National Laboratory assigned to the Y-12 Plant. Two surface streams, East Fork Poplar Creek and Bear Creek, border the facility on the south, east, and southwest sides of the Plant. There is access to the Y-12 Plant, that is controlled on Bear Creek Road on the north side of the facility; indirect access from Scarboro Road on the east side of the facility; and indirect access to the facility on the south side via Bethel Valley Road. A controlled access road from Bethel Valley Road by way of Mt. Vernon Road is located on the southwest side of the site.

It is the mission of the Y-12 Plant to serve as a key manufacturing technology center for the development and demonstration of unique materials, components, and services of importance to DOE and the nation. This is accomplished through the reclamation and 
storage of nuclear materials, manufacture of nuclear materials, manufacture of components for the defense capabilities of the nation, support to national security programs, and services provided to other customers as approved by DOE.

This application covers a treatment unit with a container storage area and three other container storage areas. These units can be located on Map 2 in Appendix B-1. The four units included in this application are as follows:

1. Building 9206 Container Storage Area

2. Building 9212 Container Storage Area

3. Building 9720-12 Classified Container Storage Area

4. Cyanide Treatment Unit

All four of these units are associated with the recovery of enriched uranium and other metals from wastes generated during the processing of nuclear materials.

\section{Building 9206 Container Storage Area}

Building 9206 is one of two buildings at the Y-12 Plant that process enriched uraniumbearing materials, including organic solutions, for recovery of the uranium. Residues were generated during past recovery processes in which solid wastes, such as gloves, shoe scuffs, lab coats, etc., that were contaminated with enriched uranium, were burned. The resulting residue or ash is now stored for future recovery of the uranium contained in the ash. The ash is classified as a mixed (hazardous and radioactive) waste due to the presence of F-listed solvents in the original solid waste.

Also stored in Building 9206 are organic solutions and lab salvage, such as phosphoric acid, Freon, etc., all containing enriched uranium. These wastes are characterized as mixed waste due to the presence of F-listed solvents and the characteristics of toxicity and corrosivity. The areas have a total storage capacity of 3,975 gallons.

\section{Building 9212 Container Storage Area}

Building 9212, located on the north side of the protected area, south of Bear Creek Road is the other building at the Y-12 Plant that processes enriched uranium bearing-materials including organic solutions. Process operations within the building also generate solid waste contaminated with uranium. Similar to Building 9206, the solid waste was burned and the resulting ash stored in cans for future recovery of the enriched uranium. 
Also stored in Building 9212 are organic solutions and lab salvage, such as phosphoric acid, Freon, etc., containing enriched uranium. These wastes are characterized was mixed waste due to the presence of F-listed solvents and the characteristics of toxicity and corrosivity. The areas have a total storage capacity of 3,814 gallons.

\section{Building 9720-12 Classified Container Storage Area}

Building $9720-12$ is a storage area for hazardous, low-level radioactive, and mixed waste. Waste is stored at this building until appropriate recycle techniques can be scheduled. Wastes stored at this facility are contaminated with enriched uranium. Total storage capacity of Building $9720-12$ container storage area is 32,500 gallons.

\section{Cyanide Treatment Unit}

The Cyanide Treatment Unit is located in Building 9201-5N in the northwest corner of the building's basement. The cyanide treatment--or destruction-operation consists of a cyanide treatment exhaust hood and a drum storage area which can store up to 2,200 gallons.

At present, the treatment process takes place in DOT-approved, plastic-lined drums. Drums of waste are placed under the cyanide treatment hood where the treatment takes place. The treatment capacity of the Cyanide Treatment Unit is 195 gallons per day.

\section{B-2 TOPOGRAPHIC MAP}

\section{B-2a General Information}

This section discusses the maps which comply to the requirements of 40 CFR Part 270.14(b)(19) and Tennessee Rule 1200-1-11-.07(5)(a)17. Appendix B-1 contains the maps that show the locations of these units as well as the general site plan, facility property boundaries, locations of buildings, and the contour of the site to show surface water flow. Due to the large number of units at the Y-12 Plant, several maps have been utilized to give the permit reviewer and writer a clearer understanding of the location of the four units in this package. The following maps are included in Appendix B-1 and have been provided to facilitate review:

Map 1: The Oak Ridge Y-12 Emergency Facilities Directory shows the general site plan. This map shows the locations of major plant buildings and other structures, the facility property boundaries, the legal boundaries of the site, the locations of portal controlled access roads, exclusion and protected areas of the plant, guard towers and 
vehicular check points. The plant access roads as well as internal roads are also shown on this map. (Scale: 1 inch $=400$ feet).

Map 2: The Oak Ridge Y-12 Plant Waste Unit Identification Key illustrates the storage, treatment, and disposal facilities located at the Y-12 Plant. Due to the large number of these facilities, a separate map has been used to give the permit writer and reviewer a clearer understanding of the locations of these facilities. (Scale: $1 \mathrm{inch}=$ 800 feet).

Map 3: The Y-12 Plant Loading and Shipping Docks Map illustrates the loading and unloading docks and shipping docks around the plant. (Scale: 1 inch $=400$ feet).

Map 4: The Y-12 Plant Floodplain Map shows the East Fork Poplar Creek 100-year floodplain and the surrounding surface waters. The 500-year floodplain and maximum probable flood is also shown for the Y-12 Plant. The four units in this package are not located within the 100-year floodplain of either Bear Creek or East Fork Poplar Creek. Flood control and drainage barriers are, therefore, not necessary. (Scale: 1 inch $=400$ feet).

Maps 5 \& 6: Y-12 Plant Sanitary Sewer System Master Plan and Y-12 Plant Storm Sewer Master Plan Maps. These maps illustrate the sanitary sewer system and the detailed storm water drainage system for the Y-12 Plant. (Scale: Sanitary Sewers 1 inch $=530$ feet, Storm Sewers -1 inch $=200$ feet $)$.

A variance under Tennessee Rule 1200-1-11-.07(5) is necessary for the required map scale of one inch equals 200 feet for these maps. The size of the $Y-12$ Plant makes the use of the required scale difficult to utilize for review. A variance has been approved for alternate map scales to be used in the application. A copy of the approval letter is included in Appendix B-1.

Information required to be submitted in this section also includes the following areas:

- Solid Waste Management Units are addressed in Section M. 
- Wind rose - Appendix B-2 includes information provided by wind roses taken from the data gathered from the two meteorological towers located at the east and west end of the plant.

- Injection and withdrawal wells. Not applicable. There are no injection wells or withdrawal wells at the facility. Therefore, there are none shown on the permit maps.

- Land Use. The surrounding land use around the Y-12 Plant is primarily wooded forest with some commercial development east of the plant.

- Loading and unloading areas. The loading and unloading areas for the container storage and treatment areas in this application are illustrated on Map 3 and also in the facility drawings referenced in Section D.

B-2b Additional Topographic Requirements for Land Storage. Treatment and Disposal Facilities and Post Closure Permits for Closed Land Units.

Not Applicable. None of these four units are hazardous waste land storage, treatment, or disposal units. Additional topographic information is not required of these hazardous waste management units in order to comply with the permit application regulations.

\section{B-3 LOCATION INFORMATION}

The locations of the four units in this permit application at the Y-12 Plant are illustrated in Map 2 of Appendix B-1. The specific identifying key numbers are summarized in Section B-1.

\section{B-3a Seismic Considerations}

Not Applicable. Since the Y-12 Plant is an existing facility and is not located in a political jurisdiction as specified in 40 CFR Part 264, Appendix VI, seismic considerations need not be addressed.

\section{B-3b Floodplain Standard}

Not Applicable. The units in this application are not located within the 100-year floodplain, therefore, this section is not required. 


\section{B-4 TRAFFIC INFORMATION}

The Y-12 Plant is a major industrial type facility operated under contract to the U.S. Department of Energy. The road system and its construction are typical of an industrial complex or military facility with numerous production, storage, administrative, maintenance, and utility buildings. These roads can easily bear the weight of the waste hauling vehicles used for each hazardous waste management unit. Roads are mostly two-way and built of asphalt to accommodate heavy and light traffic including automobiles, light trucks, armored security vehicles, heavy trucks, and tractor trailers (including those used to move nuclear material). There are also some constructed gravel roads capable of carrying the intended traffic. Entry and exit are controlled by guarded, locked gates. Internal traffic is controlled by marked lanes and stop signs at intersections typical of municipal or industrial complex surface streets. Hazardous wastes transported within the Plant or off-site generally consist of dump truck loads of soils and drums on pallets, and may periodically include tanker loads of liquids such as oils.

The minimum requirement for construction of existing paved roads at $\mathrm{Y}-12$ is 1.5 to 14.0 inches of asphaltic concrete pavement overlaid on 6.0 to 18.0 inches of compacted aggregate base. All new paved roads are constructed with a minimum of 1.5 inches of asphaltic concrete pavement overlaid on 8.0 inches of stabilized aggregate base course. All paved roads to be used for access to and exit from hazardous waste management unit areas are capable of bearing loads up to allowable state highway limitations.

Other roads used for access to and exit from hazardous waste management unit areas are constructed of crushed stone surfaces and are designed to provide all-weather utilization throughout the Y-12 Plant. These gravel access roads are constructed with a minimum of 6.0 inches of crushed stone on a prepared subgrade and are useable on a year-round basis. These gravel roads are designed to support the anticipated traffic to and from the hazardous waste management unit areas.

The access roads to the units are useable on a year-round basis to authorized personnel only. The types of vehicles typically used during operations are flatbed and pickup trucks. The fully loaded flatbed and pickup trucks will weigh about 16,000 and 8,500 pounds, respectively. The load bearing capacities of all access roads meet or exceed DOT, Bureau of Highways standards which are $33,000 \mathrm{lb}$ per axle or $24,000 \mathrm{lb}$ per axle for tandems or a maximum limit of $90,000 \mathrm{lb}$. 


\section{Building 9206 Container Storage Area}

Access to Building 9206 is from First Street at the north entrance of the facility. The building is located at the intersection of E Road and First Street. These streets are typical paved streets and meet the minimum requirements as specified for a Y-12 Plant paved road. These roads are capable of handling traffic associated with the servicing of this facility.

\section{Building 9212 Container Storage Area}

Access to Building 9212 is from G Street on the west side of the facility. The facility is just south of Bear Creek Road in the protected area. G Street is designed to meet the minimum construction requirements as specified for paved roads at the Y-12 Plant. The street is capable of handling the anticipated traffic associated with the servicing of this unit.

\section{Building 9720-12 Classified Container Storage Area}

Building 9720-12 is located on Second Street at the intersection with K Road. All these roads are paved roads and are designed and constructed to meet the minimum requirements for the Y-12 Plant paved roads. These roads are capable of handling the associated traffic necessary to service this unit.

\section{Cyanide Treatment Unit}

The Cyanide Treatment Unit is housed in Building $9201-5 \mathrm{~N}$ is located on the north side of First Street, at the intersection with J Road. All roads servicing this facility are paved roads and meet the minimum requirements for $\mathrm{Y}-12$ Plant paved roads. These roads are capable of handling the associated traffic necessary to service this unit. 


\section{SECTION C WASTE CHARACTERISTICS}

This section of the application describes the chemical and physical nature of the hazardous wastes handled and stored in each of the following storage and treatment units:

1. Building 9206 Container Storage Area

2. Building 9212 Container Storage Area

3. Building $9720-12$ Classified Container Storage Area

4. Cyanide Treatment Unit

This section also includes the waste analysis plan for sampling, testing, and evaluating the waste to assure that sufficient information is available for proper waste management. This information is submitted in response to the RCRA Part B Permit application requirements, as specified in 40 CFR Part 270.14(b)(2); and in Rules Governing Hazardous Waste Management in Tennessee, Rule 1200-1-11-.07(5)(a)2.

\section{C-1 CHEMICAL AND PHYSICAL ANALYSIS}

\section{General Description}

\section{Buildings 9206 and 9212}

Buildings 9206 and 9212 Container Storage Areas provide storage for mixed waste residues or ash. This ash resulted from the burning of solvent- and uranium-contaminated solid wastes. This ash does not contain free liquids. Uranium-bearing solutions generated during the uranium recovery process and laboratory analysis, are also stored in these areas. These solutions, as well as the residues, are considered mixed (hazardous and radioactive) wastes and are being stored prior to further uranium recovery.

\section{Building 9720-12}

Building 9720-12 provides storage for mixed (hazardous and radioactive) waste residues or ash. This ash resulted from the burning of solvent- and uranium-contaminated wastes. Unburned, solvent- and uranium-contaminated solid wastes are also stored in Building 9720-12. The wastes at Building 9720-12 contain no free liquids and are generated during the uranium recovery process. 


\section{Cyanide Treatment Unit}

The Cyanide Treatment Unit provides storage and treatment of liquid waste solutions of metallic cyanide compounds from spent plating baths and other cyanide solutions. The $\mathrm{pH}$ of the cyanide wastes ranges from 5 to 11 . The total cyanide concentration of untreated cyanide wastes ranges from 10 to $60,000 \mathrm{ppm}$. Typically, wastes generated on-site are received and treated in 55-gallon plastic lined drums. These wastes are characterized as mixed (hazardous and radioactive) wastes. Occasionally, cyanide-bearing wastes, generated off-site, may be treated at the Cyanide Treatment Unit.

\section{Hazardous Characteristics}

The storage and treatment units receive and treat only the following listed and characteristic wastes as defined in 40 CFR Part 261:

Building 9206 Container Storage Area
Building 9212 Container Storage Area
Building $9720-12$ Classified Container Storage Area
Cyanide Treatment Unit
F001, F002, F005, D004 - D043

F001, F002, F005, D004 - D043

F001, F002, F005, D004 - D043

D002 - D011, F001, F007 - F012,

P029, P030, P033, P098, P104,

P106

F005-wastes are listed only for the toxicity characteristic for those storage units that do not store ignitable waste. A summary of the types of waste stored and/or treated at these units is shown in Table C-1.

\section{Basis for Hazardous Designation}

The hazard designation is based on process knowledge of the on-site generated liquid and solid waste streams and analytical data for cyanide solutions generated off-site. Data for wastes generated on-site are considered classified for reasons of national security and are available for review by " $Q$ " cleared regulatory personnel. The information indicates the presence of F-listed solvents and TCLP metals in wastes at all the units. Specific P-listed wastes may also be present at the Cyanide Treatment Unit along with the characteristics of corrosivity and reactivity. See Appendix C-1 for typical unclassified analytical data. 
TABLE C-1. TYPICAL TYPES OF WASTE STORED AND/OR TREATED

\begin{tabular}{||l|l|l|l||}
\hline \multicolumn{1}{|c|}{ Location } & \multicolumn{1}{|c|}{ Example $^{(1)}$} & \multicolumn{1}{|c|}{ Parameter } & \multicolumn{1}{|c|}{ EPA Waste Code } \\
\hline \hline 9206 and 9212 & Ash, solutions & $\begin{array}{l}\text { Halogenated and non- } \\
\text { halogenated solvents, } \\
\text { TCLP metals }\end{array}$ & $\begin{array}{l}\text { F001, F002, F005 } \\
\text { D004 - D043 }\end{array}$ \\
\hline $9720-12$ & $\begin{array}{l}\text { Ash and solid } \\
\text { combustible } \\
\text { material }\end{array}$ & $\begin{array}{l}\text { Halogenated and non- } \\
\text { halogenated solvents, } \\
\text { TCLP metals }\end{array}$ & $\begin{array}{l}\text { F001, F002, F005 } \\
\text { D004 - D043 }\end{array}$ \\
\hline $\begin{array}{l}\text { Cyanide } \\
\text { Treatment Unit }\end{array}$ & $\begin{array}{l}\text { Spent plating } \\
\text { solutions, } \\
\text { cyanide solutions }\end{array}$ & $\begin{array}{l}\text { Cyanide and TCLP } \\
\text { metals }\end{array}$ & $\begin{array}{l}\text { D002 - D011, F001, } \\
\text { F007 - F012, P029, } \\
\text { P030, P033, P098, } \\
\text { P104, P106 }\end{array}$ \\
\hline
\end{tabular}

(1) All of these wastes could potentially be contaminated with enriched or depleted uranium.

(2) No other waste codes are processed at these units. 


\section{C-1a Containers}

\section{Buildings 9206 and 9212 Container Storage Areas}

Buildings 9206 and 9212 Container Storage Areas provide storage for mixed waste residues or ash. This ash resulted from the burning of solvent- and uranium-contaminated solid wastes. This ash does not contain free liquids and is considered a mixed waste. The containers holding the ash are made of galvanized tin and are typically 7 inches in diameter and 14 inches in height. Each can will hold approximately 2 gallons of residue. Each of the cans has a lid that slides down over the sides of the can. The seam between the lid and the side is then taped to prevent opening and the can is labeled with a recycle batch card, for uranium accountability, and a hazardous waste tag (UCN-2114A)(see Appendix C-2). The can is then placed, single-stacked, on a steel shelf with adequate spacing to prevent criticality. The shelves are normally 3 to 7 racks high with 6 to 11 cans on each shelf. Movement of all cans to and from the storage racks is done by hand. The cans are compatible with the residues being stored.

Uranium-bearing solutions generated during the uranium recovery process and during laboratory analysis are also stored in these areas. These solutions are considered mixed waste and are being stored prior to further uranium recovery. The solutions are stored in polyethylene bottles which are typically 5 inches in diameter and 52 inches in height; these bottles hold approximately 3 gallons. The bottles are labeled with a recycle batch card, for uranium accountability, and a hazardous waste tag (UCN-2114A)(see Appendix C-2). The bottle is then placed in a steel rack with adequate spacing to prevent criticality. Movement of all bottles to and from the storage racks is done by hand. The bottles are compatible with the solutions being stored. All containers of hazardous waste are labeled with the words "Hazardous Waste."

\section{Building 9720-12 Classified Container Storage Area}

Some storage is provided for ash containers from the Building 9206 and 9212 Container Storage Areas; these containers are described above. However, wastes typically arrive and are stored at Building 9720-12 in 55-gallon drums. Drums are moved by fork truck and hand carts. The drums and cans are stored in the designated area at the west end of the building. The waste is characterized as a solid material contaminated with enriched uranium, TCLP metals and F-listed solvents. The containers contain no free liquids and are compatible with the waste stored in them. The containers are labeled with recycle batch cards and hazardous 
waste tags. All containers of hazardous waste are labeled with the words "Hazardous Waste."

\section{Cyanide Treatment Unit}

Cyanide wastes from on-site generators typically arrive, are stored, and can be treated in DOT-specification 55-gallon, plastic-lined drums. These containers are compatible with the wastes stored in them. The drums can be stored in the adjacent storage area. All drums of hazardous waste are labeled with the words "Hazardous Waste" (typically UCN-2114A). After treatment, if the cyanide levels are less than $10 \mathrm{ppm}$, the drums are shipped to the West End Treatment Facility.

Occasionally, cyanide waste may be received from off-site generators. Containers received from off-site must be in the appropriate DOT-specification container which are compatible with the waste stored in them.

The specific parameters to be used for the proper management of the stored and treated wastes is the concentration of enriched uranium. The Cyanide Treatment Unit is an exception, since the concentration of cyanide is the major concern. Other considerations at these units include the presence of F-listed solvents and TCLP metals based on process knowledge. Specific P-listed and characteristic wastes defined in Section C-1 are also of concern at the Cyanide Treatment Unit. The safe handling of waste is of primary importance. Handling of a waste will occur only when material is being transferred to or removed from a storage or treatment area. All equipment used to transfer waste is compatible with the waste.

Waste acceptance criteria precludes the storage of reactive, incompatible, or ignitable waste at Buildings 9206, 9212, and 9720-12. Reactive waste (D003) is treated at the Cyanide Treatment Unit. Ignitable waste is not processed at the Cyanide Treatment Unit.

\section{C-1b Tanks}

Not applicable. The units covered in this permit application are not tanks; therefore, the requirements of this section do not apply.

\section{C-1c Waste Piles}

Not applicable. The units covered in this permit application are not waste piles; therefore, the requirements of this section do not apply. 


\section{C-1d Surface Impoundments}

Not applicable. The units covered in this permit application are not surface impoundments; therefore, the requirements of this section do not apply.

\section{C-1e Incinerators}

Not applicable. The units covered in this permit application are not incinerators; therefore, the requirements of this section do not apply.

\section{C-1f Landfills}

Not applicable. The units covered in this permit application are not landfills; therefore, the requirements of this section do not apply.

\section{C-1g Land Treatment}

Not applicable. The units covered in this permit application are not land treatment facilities; therefore, the requirements of this section do not apply.

\section{C-1h Additional Requirements for Land Storage, Treatment, and Storage Facilities}

Not applicable. The units covered in this permit application are not land storage, treatment, or disposal facilities; therefore, the requirements of this section do not apply.

\section{C-2 WASTE ANALYSIS PLAN}

The waste analysis plan is included to describe the procedures for obtaining the chemical and physical characteristics of a waste. Characterization is necessary to ensure proper management of the waste and compliance with the EPA land disposal restrictions.

Due to the nature of Y-12 operations, all chemicals used in the various operations are identified either from original, manufacturer-labeled containers or by laboratory analysis requested by the individual generator. Mixtures of substances originate in the same fashion, and therefore are identifiable by means of the identifying tag system shown in Appendix C-2.

\section{C-2a Parameters and Rationales}

\section{Buildings 9206, 9212, and 9720-12 Container Storage Areas}

Waste sent to each of these locations is analyzed for enriched uranium. Process knowledge is used to determine the presence of other RCRA constituents. 


\section{Cyanide Treatment Unit}

The cyanide waste solutions are generated in plating shops and other Y-12 Plant operations. On occasion, cyanide waste solutions may be received from off-site. These solutions are transported in compatible, DOT-specification containers to the Cyanide Treatment Unit where the cyanide is decomposed prior to further treatment. All drums of untreatable cyanide solutions are tested using the Prussian Blue Test.

After cyanide decomposition, each drum is sampled and analyzed for free cyanide, total cyanide, and cyanate concentrations to verify the effectiveness of treatment. Treated wastes found to have a cyanide concentration of $10 \mathrm{ppm}$ or below are sent to the West End Treatment Facility. Treated waste with a cyanide concentration greater than $10 \mathrm{ppm}$ is processed in the treatment unit again. Treated cyanide solutions are typically analyzed for the parameters shown in Table C-2 as part of the waste analysis plan for any wastes to be treated at West End Treatment Facility.

The cyanide solutions treated at this facility are not ignitable liquids.

\section{C-2b Test Methods}

The analytical methods are summarized in Table C-3.

If additional analysis is deemed necessary, wastes will be analyzed using methods described in EPA SW-846, EPA 600/4-79-020, or "Environmental and Effluent Analysis Manual, Nuclear Division Environmental Control."

\section{C-2c Sampling Methods}

\section{Sampling:}

The contents of each container of waste will be characterized by either process knowledge or analysis prior to transfer to the container. The characterization will remain valid until the process changes.

Container sampling of liquids will be performed by use of an all glass Coliwasa drum sampler as described in SW-846. The use of the Coliwasa sampler will provide a representative vertical cross section of the contents of the drum or container and thereby address any anomalies that could develop due to vertical stratification.

Solid wastes are sampled using the methods shown in Table C-4. 
TABLE C-2. TYPICAL ANALYTICAL PARAMETERS FOR TREATED CYANIDE SOLUTIONS

pH

Nitrates

TOC

$\mathrm{U}$

$\mathrm{Cl}$

Total residual $\mathrm{Cl}$

$\mathrm{F}$

As

$\mathrm{Ba}$

$\mathrm{Cd}$

$\mathrm{Cr}$

$\mathrm{Pb}$

$\mathrm{Hg}$

$\mathrm{Se}$

$\mathrm{Ag}$

Cl hydrocarbons

PCB

Phosphates

Sulfates

Cyanide

COD

Suspended solids

Dissolved solids

Alkalinity (as $\mathrm{CaCO}_{3}$ )

Acidity

Density

$\begin{array}{ll}\mathrm{Al} & \text { Alpha activity } \\ \mathrm{B} & \text { Beta activity } \\ \mathrm{Be} & \text { Gamma activity } \\ \mathrm{Ca} & \\ \mathrm{Ce} & \text { Methylene chloride } \\ \mathrm{Co} & \text { Methyl chloroform } \\ \mathrm{Cu} & \text { Trichloroethylene } \\ \mathrm{Fe} & \text { Perchloroethylene } \\ \mathrm{Ga} & \text { Freon 113 } \\ \mathrm{K} & \text { Chlorobenzene } \\ \mathrm{La} & 1,1-\text { Dichloroethane } \\ \mathrm{Li} & 1,1-\text { Dichloroethylene } \\ \mathrm{Mg} & \text { Chloroform } \\ \mathrm{Mn} & 1,2-\text { Dichloroethylene } \\ \mathrm{Mo} & 1,1,2-\text { Trichloroethane } \\ \mathrm{Na} & 1,2-\text { Dichloroethane } \\ \mathrm{Nb} & \text { Carbon tetrachloride } \\ \mathrm{Ni} & \\ \mathrm{P} & \text { Acetone } \\ \mathrm{Sc} & \text { Ethanol } \\ \mathrm{Si} & \text { Methyl ethyl ketone } \\ \mathrm{Sr} & \text { Phenol } \\ \mathrm{Th} & \text { Carbon disulfide } \\ \mathrm{Ti} & \text { Toluene } \\ \mathrm{V} & \\ \mathrm{Y} & \\ \mathrm{Zn} & \mathrm{Zr}\end{array}$


TABLE C-3. TEST METHODS FOR PRODUCTION ASSOCIATED WASTES*

\begin{tabular}{|l|c|}
\hline \multicolumn{1}{|c|}{ Analyte } & Analytical Method \\
\hline \hline Uranium & 2100 \\
\hline TCLP & 1311 \\
\hline Volatile organics & 5030,8740 \\
\hline Semi-volatile organics & 8250,8270 \\
\hline Aqueous phase $\mathrm{pH}$ & 9040 \\
\hline
\end{tabular}

* Methods referenced from "Test Methods for Evaluating Solid Waste" (SW-846) 
TABLE C-4. SAMPLING EQUIPMENT FOR PARTICULAR WASTE TYPES

\begin{tabular}{|c|c|c|c|c|c|c|c|c|}
\hline \multirow[t]{2}{*}{ Waste Type } & \multicolumn{8}{|c|}{ Waste location or container } \\
\hline & Drum & $\begin{array}{l}\text { Sacks } \\
\text { and bags }\end{array}$ & $\begin{array}{l}\text { Open-bed } \\
\text { truck }\end{array}$ & $\begin{array}{l}\text { Closed-bed } \\
\text { truck }\end{array}$ & $\begin{array}{l}\text { Storage } \\
\text { tanks } \\
\text { or bins }\end{array}$ & $\begin{array}{l}\text { Ponds, } \\
\text { lagoons } \\
\text { and pits }\end{array}$ & $\begin{array}{c}\text { Conveyor } \\
\text { belt }\end{array}$ & Pipe \\
\hline $\begin{array}{l}\text { Moist powders } \\
\text { or granules }\end{array}$ & Trier & Trier & Trier & Trier & Trier & Trier & Shovel & Dipper \\
\hline $\begin{array}{l}\text { Dry powders } \\
\text { or granules }\end{array}$ & Thief & Thief & Thief & Thief & Thief & Trier & Shovel & Dipper \\
\hline $\begin{array}{l}\text { Sand or packed } \\
\text { powders and } \\
\text { granules }\end{array}$ & Auger & Auger & Auger & Auger & $\mathrm{b}$ & b & Dipper & Dipper \\
\hline $\begin{array}{l}\text { Large-grained } \\
\text { solids }\end{array}$ & $\begin{array}{l}\text { Large } \\
\text { trier }\end{array}$ & $\begin{array}{l}\text { Large } \\
\text { trier }\end{array}$ & $\begin{array}{l}\text { Large } \\
\text { trier }\end{array}$ & $\begin{array}{l}\text { Large } \\
\text { trier }\end{array}$ & $\begin{array}{l}\text { Large } \\
\text { trier }\end{array}$ & $\begin{array}{l}\text { Large } \\
\text { trier }\end{array}$ & Trier & Dipper \\
\hline
\end{tabular}

${ }^{a}$ Source -- EPA-SW-846; sampling methods described therein will be utilized.

- This type of sampling situation can present significant logistical sampling problems; therefore, sampling equipment must be specifically selected or designed based on site and waste conditions. No general statement about appropriate sampling equipment can be made. 


\section{Sample Handling:}

Once the sample is transferred to the sample container, the lid is closed tightly and taped closed. The exterior of the sample container is washed, dried, and a sample identification tag attached. At a minimum, the tag identifies the sample, the sample location, time of sample, sampler, preservatives, and a unique sample identification number. The sample containers are placed in a plastic bag, tied closed, and placed in a sample ice chest with ice or equivalent. An analytical request form and chain-of-custody form will accompany the sample to the laboratory. The analytical request form identifies the sample number with the tag that is affixed to the sample container(s).

\section{Reporting:}

All analytical results, generator information, and sample chain-of-custody documentation will be maintained in the operating record.

\section{C-2d Frequency of Analysis}

\section{Buildings 9206, 9212, and 9720-12 Container Storage Areas}

Sampling and analysis are not conducted for waste in containers which already have proper labels identifying the source of their contents and associated hazard classification. Generators are responsible for analyzing wastes when process changes occur to ensure accurate and up-to-date information for the storage unit operators. The contents of each unique batch of waste is characterized by either analysis or by process knowledge, before shipment to the storage areas.

If analytical results are not available, process knowledge will be used to determine the appropriate storage area to be used for the waste shipment. Characterization necessary to ensure safe handling, regulatory compliance, and compatibility will be required before a waste is transferred off-site. Characterization required for land disposal must be complete before the waste is removed. A waste characterization will remain valid until the generating process changes.

\section{Cyanide Treatment Unit}

Each drum or batch of waste is sampled and analyzed before and after treatment. Characterization necessary to ensure safe handling, regulatory compliance, and compatibility will be required before the treated waste is transferred off-site for final disposal. 


\section{C-2e Additional Requirements for Waste Generated Off-Site \\ Cyanide Treatment Unit}

The generator will be responsible for supplying all information required for each parameter identified by this waste analysis plan. No waste will be accepted into these units until all the required information has been adequately provided.

In order to minimize the exposure of personnel to radiation and hazardous wastes, the containers of waste will not be routinely resampled for the purpose of complying with the waste analysis requirements. Chain-of-custody seals will be used to ensure that the wastes have not been tampered with after sampling by the generator. The chain-of-custody procedures for shipping and receiving off-site generated wastes include the following:

- The generator will sample and analyze the wastes for verification parameters specified in Table C-2 prior to shipping the waste to the Cyanide Treatment Unit.

- Immediately after sampling, the waste container will be sealed by the generator and a chain-of-custody seal will be affixed to the container, with the identification number of the chain-of-custody seal recorded on the waste analysis sheet.

- The manifest will be given to the transporter. The transporter and generator will check the identification number on the chain-of-custody seal with the number recorded on the waste analysis sheet to ensure that they are the same. Both the generator and transporter will check, sign, and date the manifest before the shipment and transporter depart the generator site.

- Upon arrival at the Y-12 Plant Cyanide Treatment Unit, the transporter will give the manifest and waste analysis sheet to the operations supervisor. The transporter and the operations supervisor will check the number on the waste analysis sheet and on the manifest to ensure that they are the same. An operations supervisor will inspect the load and will match the identification number of the chain-of-custody seal and the waste containers to those recorded on the waste analysis sheet. An operations supervisor and transporter will then sign and date the manifest. Significant discrepancies are defined as a difference in the number of containers reported and the number received or a difference in the type of waste identified and that received. Any significant discrepancies will be handled in accordance with Tennessee Rule 1200-1-11$.06(5)(c)$, and copies of all discrepancy reports and resolutions will be entered in the 
site operating records. The waste will not be off-loaded during resolutions of the discrepancies and if the discrepancy cannot be resolved within 10 days, the waste will be returned to the generator.

The hazardous waste generator will be responsible for characterizing their waste. Waste received from off-site generators will be accompanied by an LDR-notification that has been prepared in accordance with Tennessee Rule 1200-1-11-.10 and 40 CFR Part 268.7(a)1,3, or 5 and signed by the generator.

See Section $\mathrm{J}$ for additional information regarding the written operating record.

C-2f Additional Requirements for Facilities Handling Ignitable, Reactive, or Incompatible Waste

Waste characteristics have been reviewed for compatibility using a Y-12 Plant hazardous waste compatibility table similar to the list found in Tennessee Rule 1200-1-11-.06, Appendix .06/B, Examples of Potentially Incompatible Waste. See Appendix C-3 and Sections C-1, C-3, C-5 for additional information.

Mixing of incompatible wastes will also be prevented by requirements that the on-site generators provide information based on process knowledge or on testing describing the waste contents and characteristics. A compatibility review is an element of the waste acceptance criteria. Personnel will determine compatibility using waste handling history and other available data.

Based on waste handling history, and a review of the incompatible groupings, wastes stored at Buildings 9206, 9212, and 9720-12 normally will not be reactive, ignitable, or incompatible.

Wastes stored and treated at the Cyanide Treatment Unit are considered to be reactive due to the presence of cyanide. Once the treatment process has been completed, the waste material is no longer considered reactive. Section F-5a discusses the procedures used to prevent accidental reaction of wastes.

\section{C-3 LAND DISPOSAL RESTRICTIONS}

C-3a Waste Characteristics

Specific data must be submitted by the generator to the owner/operator of a treatment or disposal facility to document whether the waste is restricted under the 40 CFR Part 268 
requirements. This data will be obtained by analysis of container contents and by knowledge of process. Waste determined to be restricted will be stored separately from non-restricted waste.

\section{C-3a(1) Solvent Wastes and Dioxin-Containing Wastes}

The wastes generated at the Y-12 Plant do not contain dioxin or dioxin-containing constituents based on knowledge of the processes. The wastes could contain solvents in the F-listed solvent classification. Since the exact composition of the solvent constituents will vary, the wastes will be considered to be F001, F002, and/or F005 wastes. This characterization is based on analytical data and on knowledge of solvent use at the Y-12 Plant. The wastes stored or treated in each of the units meet the definition of nonwastewater as defined in 40 CFR Part 268.2.

\section{C-3a(2) California List Wastes}

The California List places restrictions on liquid hazardous wastes containing PCBs greater than or equal to $50 \mathrm{ppm}$, over $1,000 \mathrm{ppm}$ halogenated organic constituents, and liquids testing less than or equal to a $\mathrm{pH}$ of 2 . All of the wastes stored at these units could contain constituents exceeding the halogenated organic criteria. Based on knowledge of process, liquids testing less than or equal to $2 \mathrm{pH}$ could be stored in containers. Testing will be conducted to ensure that PCBs are not present above $0.1 \mathrm{ppm}$. Wastes received in containers will be limited to those waste codes listed in Section C-1.

\section{C-3a(3) First-Second-and-Third-Third Waste}

Based on knowledge of the waste characteristics, the Cyanide Treatment Unit may receive P-listed wastes, and TCLP wastes, which are subject to land disposal restrictions under 40 CFR Part 268 (Tennessee Rule 1200-1-11-10). Wastes received at this unit will be limited to those waste codes listed in Section C-1. The wastes meet the definition of nonwastewater as defined in 40 CFR Part 268.2 .

\section{C-3b Additional Requirements for Treatment Facilities}

\section{Cyanide Treatment Unit}

All cyanide wastes treated at the Cyanide Treatment Unit are tested after each batch to ensure that the cyanide concentration is less than $10 \mathrm{ppm}$. If it is not, the batch is recycled for further treatment. All analytical test results are considered part of the operating records. 


\section{C-3c Additional Requirements for Disposal Facilities}

Not applicable. The units covered in this permit application are not disposal facilities; therefore, the requirements for this section do not apply.

\section{C-3d Additional Requirements for Surface Impoundments Exempted from Land Disposal Restrictions}

Not applicable. The units covered in this permit application are not surface impoundments; therefore, the requirements for this section do not apply.

C-3e Requirements for Land Disposal Facilities With an Approved Exemption or Extension Not applicable. The units covered in this permit application are not land disposal facilities; therefore, the requirements for this section do not apply. 


\section{SECTION D \\ PROCESS INFORMATION}

This section discusses specific process information for the storage and treatment of hazardous wastes at four container storage areas and one treatment unit at the Y-12 Plant. These four units can be located on Map 2 in Appendix B-1. The four units addressed in this application include the following:

1. Building 9206 Container Storage Area

2. Building 9212 Container Storage Area

3. Building 9720-12 Classified Container Storage Area

4. Cyanide Treatment Unit

As required by 40 CFR Part 270.15 and Rules Governing Hazardous Waste Management in Tennessee, Rule 1200-1-11-.07(5)(b)1., this section describes the hazardous waste management processes used at the four areas.

\section{Building 9206 Container Storage Area}

Container storage at Building 9206 consists of storage and staging areas located on the first and second floors of the building. The container storage areas store residues and uraniumbearing solutions. Containers are stored in steel racks or on shelves. The total storage capacity of the container storage area at Building 9206 is 3,975 gallons.

\section{Building 9212 Container Storage Area}

Container storage at Building 9212 consists of storage and staging areas located on the first floor and mezzanine level. The container storage areas store residues and uranium-bearing solutions. Containers are stored in steel racks or on shelves. The total storage capacity of the container storage area at Building 9212 is 3,814 gallons.

\section{Building 9720-12 Classified Container Storage Area}

The Classified Container Storage Area is used for the storage of solid, mixed (radioactive and hazardous) wastes generated at the Y-12 Plant. The stored materials include combustible, solid wastes contaminated with enriched uranium and listed wastes. The total storage capacity of the container storage area at Building $9720-12$ is 32,500 gallons. 


\section{Cyanide Treatment Unit}

The Cyanide Treatment Unit is located in the northwest corner of the basement in Building $9201-5 \mathrm{~N}$. The cyanide treatment process converts cyanide in solution to carbon dioxide and nitrogen. The waste is currently treated in the drums in which it is stored. The treatment capacity of the unit is 195 gallons per day and the storage capacity is 2,200 gallons.

\section{D-1 CONTAINER SYSTEMS}

This section describes the storage and treatment capabilities of each unit.

D-1a Containers with Free Liquids

Some containers at Buildings 9206, 9212, and the Cyanide Treatment Unit have free liquids. The containers at Building 9720-12 do not have free liquids.

Wastes stored at Building 9206, 9212, and 9720-12 are characterized by the waste codes F001, F002, F005, D004 - D043. The waste stored at these units is in the form of residues and uranium-bearing solutions. Waste stored and treated at the Cyanide Treatment Unit are characterized as D002 - D011, F001, F007 - F012, P029, P030, P033, P098, P104, and $\mathrm{P} 106$, and are in the form of cyanide solutions.

\section{D-1a(1) Basic Design Parameters, Dimensions and Materials of Construction $\underline{9206}$}

Plan views of the container storage areas within Building 9206 are shown in Appendix D-1. The container storage areas contain the following number of storage racks:

\begin{tabular}{ccc} 
Areas in 9206 & Solutions Spaces & Residue Spaces \\
\hline First Floor & 138 & 166 \\
Second Floor & 0 & 185 \\
Butler Building & 72 & 1,068 \\
\hline
\end{tabular}

Building 9206 is a major industrial-type building at the Y-12 Plant. Its construction is typical of an industrial or military facility. The building is capable of bearing the load of numerous types of production, storage, utility, and maintenance equipment, as well as personnel. The floors of the rooms on the first floor are constructed of concrete and covered with sheets of stainless steel. Seams in the stainless steel floor are welded which provides an impervious floor that is free of cracks and gaps. The floor on the second floor is concrete, covered with 
asphalt tile and the floors in the Butler Building and the staging area are concrete. The concrete floors of the storage units are free of cracks and gaps and are sufficiently impervious to contain spills. All galvanized tin cans and polyethylene bottles are stored on steel shelves or racks. The shelves and racks are capable of supporting the weight of the waste containers. The racks, shelves, and floors are compatible with the wastes stored. The storage capacity of this area is 3,975 gallons.

$\underline{9212}$

Plan views of the container storage areas within Building 9212 are shown in Appendix D-1. The container storage areas contain the following number of storage racks:

Areas in $9212 \quad$ Solutions Spaces Residue Spaces

\begin{tabular}{ccc}
\hline C-1 Wing & 315 & 0 \\
C-1 Wing Mezzanine & 163 & 598 \\
C-1 Wing Corridor & 0 & 216 \\
Headhouse & 0 & 161 \\
Staging & 0 & 12 \\
\hline
\end{tabular}

Building 9212 is a major industrial-type building at the Y-12 Plant. Its construction is typical of an industrial or military facility. The building is capable of bearing the load of numerous types of production, storage, utility, and maintenance equipment, as well as personnel. The floor in the storage areas is stainless steel. Seams in the stainless steel floor are welded which provides an impervious floor that is free of cracks and gaps. The floor of the staging area is made of concrete and is tree of cracks and gaps and is sufficiently impervious to contain spills. The racks, shelves, and floors are compatible with the wastes stored and are capable of supporting the weight of the waste containers. All galvanized tin cans and polyethylene bottles are stored on steel shelves or racks. The storage capacity of this area is 3,814 gallons.

\section{0-12}

A plan view of the Classified Container Storage Area is shown in Appendix D-1. The container storage area measures 93 by 50 feet. The base of the storage area is the concrete floor of the building. All drums are stored on pallets, double-stacked, and contain no free liquids. Storage spaces for 384 galvanized tin cans are provided as well. The cans are stored 
on elevated racks and contain no free liquids. The shelves and racks are capable of supporting the weight of the waste containers. The floor of the storage unit is free of cracks and gaps and is sufficiently impervious to contain spills. The racks, shelves, and floors are compatible with the wastes stored. The base of the storage area is sufficient to support the weight of the waste containers in the unit. The storage capacity for this area is 32,500 gallons.

\section{Cyanide Treatment Unit}

The Cyanide Treatment Unit is shown in plan view in Appendix D-1. The storage area can store up to forty, 55-gallon drums of cyanide waste. The area has a 2 -inch curb on a concrete base floor that is free of gaps and cracks. Asphalt tiles have been applied to floor surface to prevent spills from migrating. All drums are stored single-stacked on pallets. The floor is capable of supporting the weight of the waste containers. The treatment capacity of the unit is 195 gallons/day; the storage capacity of the unit is 2,200 gallons.

Building $9201-5 \mathrm{~N}$ is a major industrial-type building at the Y-12 Plant. Its construction is typical of an industrial or military facility. The building is capable of bearing the load of numerous types of production, storage, utility, and maintenance equipment, as well as personnel. The floor of the Cyanide Treatment Unit is the first floor, eight-inch concrete slab of Building 9201-5N. A 2-inch high, coated concrete ramp separates the Cyanide Treatment Unit from the other portion of the shared room. A 4-inch high concrete curb installed along the base storage cabinets also separates the Cyanide Treatment Unit from the rest of the room.

\section{D-1a(2) Description of How Design Promotes Drainage or How Containers are Kept from Contact with Standing Liquids in Containment System}

As was noted in Section B, the four container storage or treatment areas are located in buildings that are covered by roofs.

\section{6 and 9212}

All Containers are stored on elevated racks or shelves to prevent contact with any liquids on the floor.

$\underline{9720-12}$

Drummed wastes are stored upright on pallets to prevent possible contact with standing liquids. All cans stored are on elevated racks, similar to those in Buildings 9206 and 9212, 
to prevent possible contact with any liquid on the floor. Waste containing free liquids is not stored in Building 9720-12.

\section{Cyanide Treatment Unit}

The unit is located in the basement of a Building 9201-5N. Drummed wastes are stored upright on pallets to prevent possible contact with standing liquids. A maximum of 2,200 gallons of drummed waste is stored at the Cyanide Treatment Unit and the drums are not stacked. Two-inch high, coated concrete curbs and ramps exist to prevent the flow of liquids to adjoining areas and to contain any spills or leaks within the area until they are properly removed.

\section{D-1a(3) Capacity of the Containment System Relative to the Number and Volume of the Containers to be Stored}

Conventional secondary containment is not provided for liquid waste storage areas at Buildings 9206 and 9212 due to criticality safety concerns. Because the wastes contain enriched uranium, construction of diking or other conventional secondary containment would result in unsafe storage geometries that could potentially result in a nuclear criticality accident. The safe storage of liquid wastes at Buildings 9206 and 9212 is of primary importance due to criticality safety. The volume of the largest liquid container is approximately 3 gallons. Buildings 9206 and 9212 are designed to prevent these materials from contacting humans or the environment. These buildings do not contain floor drains and door to the outside are sealed to prevent potential spills from migrating to the environment.

Free liquids are not stored at Building 9720-12. Secondary containment is not required since spills of liquid cannot occur.

\section{Cyanide Treatment Unit}

The maximum number of drums in this storage and treatment unit is 40 , with a total capacity of 2,200 gallons. Calculations for secondary containment capacity are presented below:

\section{Containment Volume}

$37 \mathrm{ft} \times 15.6 \mathrm{ft} \times 2 / 12 \mathrm{ft} \times 7.48 \mathrm{gal} / \mathrm{ft}^{3}=720 \mathrm{gal}$

$26.5 \mathrm{ft} \times 17.2 \mathrm{ft} \times 2 / 12 \mathrm{ft} \times 7.48 \mathrm{gal} / \mathrm{ft}^{3}=568 \mathrm{gal}$

$10 \mathrm{ft} \times 6.8 \mathrm{ft} \times 2 / 12 \mathrm{ft} \times 7.48 \mathrm{gal} / \mathrm{ft}^{3}=85 \mathrm{gal}$

$12 \mathrm{ft} \times 9.1 \mathrm{ft}=109 \mathrm{gal}$ 
Containment Volume $=720 \mathrm{gal}+568 \mathrm{gal}-85 \mathrm{gal}-109 \mathrm{gal}=1,094 \mathrm{gal}$

Drum Displacement

$40 \times(2 \mathrm{ft})^{2} \times \pi \times 0.25 \times 0.167 \mathrm{ft}=21 \mathrm{ft}^{3}$

$21 \mathrm{ft}^{3} \times 7.48 \mathrm{gal} / \mathrm{ft}^{3}=157 \mathrm{gal}$

Pallet Displacement

$10 \times 12 \mathrm{gal} / \mathrm{pallet}=120 \mathrm{gal}$

Total Displacement $=157 \mathrm{gal}+120 \mathrm{gal}=277 \mathrm{gal}$

Total Available Secondary Containment

1,094 gal -277 gal $=817$ gallons

Excess Containment Capacity

$10 \%$ required $=2,200$ gal $\times 0.1=220$ gal

$817 \mathrm{gal}-220 \mathrm{gal}=597$ gallons

Secondary containment volume is required to hold at least $10 \%$ of the volume of the containers. There is a 597-gallon excess of secondary containment capacity at the Cyanide Treatment Unit.

\section{D-1a(4) Provisions for Preventing or Managing Run-On}

The container storage areas at Buildings $9206,9212,9720-12$, and the Cyanide Treatment Unit are completely enclosed with walls and a roof to prevent accumulation of rainfall in the storage and treatment areas. In addition, the Cyanide Treatment Unit is diked to prevent run-on from adjacent areas.

\section{D-1a(5) How Accumulated Liquids can be Analyzed and Removed to Prevent Overflow Buildings 9206 and 9212}

Accumulated liquids would only be present at Buildings 9206 and 9212 as a result of a spill or leak from the containers. If the spill or leak can be traced to a particular container, the characterization of the waste may already be known. If the source of the liquid cannot be identified, the collected material will be sampled and analyzed. Spilled or leaked waste liquid would be stored at the unit.

Removal of spilled liquids will be accomplished by the use of criticality safety-approved methods. Accumulated liquids will be removed immediately upon their discovery. See Sections F-2c and G-5f for additional information in the event of a release. 


\section{Building 9720-12}

Accumulated liquid at $9720-12$ would be from wind-driven precipitation or utility leaks since no free liquids are stored in these containers.

\section{Cyanide Treatment Unit}

Accumulated liquids at the Cyanide Treatment Unit could be present as a result of a spill or leak from the container within the diked area. If the spill or leak can be traced to a particular drum, the analysis may already be known. If the source of the liquid cannot be identified, the collected material will be sampled and analyzed. Spilled or leaked waste liquid would be treated at the unit.

Removal of spilled liquids will be accomplished by the use of portable pumps or by the use of absorbent material depending on the quantity of material present. Accumulated liquids will be removed immediately after their discovery. See Section F-2c and G-5f for additional information in the event of a release.

\section{D-1b Containers Without Free Liquids}

All wastes stored at Building 9720-12 and some of the wastes at Building 9206 and 9212 will be without free liquids. These wastes will be clearly defined by tagging. The waste stored at $9720-12$ is characterized as solid, mixed waste.

\section{D-1c(1) Container Management}

Residues stored at Buildings 9206, 9212, and 9720-12 are stored in specially fabricated galvanized tin cans. The cans are typically 14 inches in height and 7 inches in diameter. They will hold approximately 2 gallons of residue. The cans have slip-type lids that slide down over the top of the vessel approximately 1 inch. The lid is then sealed with tape.

The cans are placed single-stacked on steel racks, typically with 3 to 7 shelves. Usually 6 to 11 cans can be stored on a shelf depending on the length of the rack. The cans are kept approximately 2 feet apart for criticality safety spacing requirements. Cans are transferred to and from the shelves by hand. Cans will be moved to the staging areas in Buildings 9206 and 9212 only when they are being removed from the area. These staging areas are a holding area during material transfer. Containers are inspected/audited monthly for uranium accountability. 
Liquid storage bottles are approximately 52 inches in height and 5 inches in diameter. These containers are specially designed for criticality safe storage of nuclear materials. These bottles have a threaded lid and will hold approximately 3 gallons of waste. Bottles are transferred to and from the racks by hand. The bottles are stored approximately 2 feet apart for criticality safety.

Additional wastes at Building 9720-12 and the Cyanide Treatment Unit are typically stored in 55-gallon drums. The waste stored at Building $9720-12$ is solid, mixed waste. A total of 144 pallets with 4 drums each can also be stored in the unit. Aisle spacing is typically 36 inches.

Wastes stored at the Cyanide Treatment Unit are stored in DOT-specification drums, typically 55-gallons, compatible with the cyanide solutions. Aisle spacing is adequate to allow inspections and movement of equipment. Containers are single-stacked.

Several steps have been taken to prevent hazards during loading/unloading operations. Drum handling operations typically take place when drums are placed into storage during treatment operations. To minimize the potential for accidents involving other vehicles and pedestrians, traffic flow is limited around the loading area during operations. All drum handling equipment used (carts, lifts, etc.) are specifically designed to transport or lift drums safely and without damage. Ramps or roll-over dikes have been constructed to allow wheeled vehicles (carts, forklifts, etc.) easy access to containers while still providing containment for spilled liquids.

All waste containers in the storage areas are sealed at all times except during filling operations (for solvents and other liquids), packing for shipment, or for sampling purposes. Containers are handled (i.e., moved, loaded onto trucks, filled, etc.) only under the direction of the production supervision. Funnels appropriately designed and fabricated are used with drums for pouring liquids. Wastes at the Cyanide Treatment Unit are treated in open containers. Procedures exist that detail the safe operation of the cyanide treatment process. See Section D-1c(2) for more information.

Drums used for hazardous waste storage are either new, reconditioned, or cleaned (by rinsing or other appropriate measure) or contain new material that is know to be compatible with the waste to be added. Polyethylene drum liners $(4 \mathrm{ml})$ are used for wastes not compatible with steel drums. Drums containing incompatible wastes are generally 
segregated by DOT hazard class and whenever possible, drums containing wastes known to be incompatible are stored in the different areas or kept separate via portable dikes.

All containers are observed during packing and loading operations. Also, all containers are inspected at least weekly on an individual basis for deterioration, corrosion, leakage, etc.; a listing, illustrative of the inspection technique for this facility, is given in Section F-2. Any container that does not pass inspection is replaced within 24 hours with one that meets the proper requirements.

The storage areas have aisles for the passage and maneuver of a drum dolly accessing the segregated waste storage area. This aisle is kept clear of drums or equipment; drums are sorted in the designated, segregated areas.

Aisle spacing is typically 3 feet by 5 feet wide with a minimum of 36 inches. Actual operating layouts of each of the areas is shown in D-1 through D-8.

Drums may be stacked only at Building $9720-12$ and are stored on pallets. The maximum number of drums that could be stored in each unit is 576 at Building $9720-12$, and 40 at the Cyanide Treatment Unit.

\section{D-1c(2) Requirements for Ignitable or Reactive Wastes and Incompatible Wastes} The wastes stored at Buildings 9206, 9212, and 9720-12 are not ignitable, reactive, or incompatible (see Section C-1).

The cyanide wastes stored and treated at the Cyanide Treatment Unit are not ignitable or incompatible, but are considered to be reactive (D003). The treatment process eliminates the reactivity once it is complete.

The Cyanide Treatment Unit and the precious metals recovery operation share the same room; therefore, the possibility exists that the acids used in the precious metal recovery process and the cyanide wastes could, through accident, mix and generate hydrogen cyanide ( $\mathrm{HCN}$ ) gas. At present, curbing exists in the shared area to separate stored acids, stored cyanide wastes, acid exhaust hoods, and the cyanide treatment exhaust hoods. The exhaust hoods for these two processes are separate units with separate venting, and the drums of these incompatibles are physically separate in the room. Additionally, drums of acid and 
cyanide are clearly marked "ACID" or "CYANIDE". Only material with an appropriate label is processed or stored in a process-specified hood.

The unit personnel are fully trained in precautions to prevent mixing acids and cyanides, and this topic is discussed frequently in regular safety meetings. Personnel are also trained by means of a sniff test developed by DuPont to recognize the odor of hydrogen cyanide gas.

No ignitable wastes are stored or processed at the Cyanide Treatment Unit.

Building $9201-5 \mathrm{~N}$ is located more than 15 meters ( 50 feet) from the plant boundary.

\section{D-2 TANK SYSTEMS}

Not applicable. The units covered in this permit application are not tank systems; therefore, the requirements of this section do not apply.

\section{D-3 WASTE PILES}

Not applicable. The units covered in this permit application are not waste piles; therefore, the requirements of this section do not apply. 


\section{SECTION E GROUNDWATER MONTTORING}

Groundwater monitoring is not required for Building 9206, 9212, and 9720-12 Container Storage Areas and the Cyanide Treatment Unit as per the requirements of 40 CFR Part 264, Subpart F and Tennessee Rule 1200-1-11-.07(5)(c) which exclude container storage areas from the groundwater monitoring requirement. 


\section{SECTION F \\ PROCEDURES TO PREVENT HAZARDS}

This section of the application provides information concerning procedures to prevent hazards required by 40 CFR Part 270.14 and Rules Governing Hazardous Waste Management in Tennessee, Rule 1200-1-11-.07(5)(a). The following subject areas are addressed in this section: general security provisions, inspection schedules and requirements, preparedness and prevention requirements, and prevention of accidental ignition or reaction of ignitable, reactive, or incompatible wastes at Buildings 9206, 9212, and 9720-12 Container Storage Areas, and the Cyanide Treatment Unit.

\section{F-1 SECURITY}

\section{F-1a Security Procedures and Equipment}

The Y-12 Plant maintains security procedures and equipment that prevent the unknowing entry of persons or livestock onto the active portion of the facility which minimizes the possibility for unauthorized entry. The 24 hours per day, 7 days per week surveillance system is utilized at the Y-12 Plant, and one or more barriers are present to control entry.

\section{F-1a(1) 24-Hour Surveillance System}

The Y-12 Plant is a DOE facility which produces and handles nuclear materials. It is a fully secure facility completely surrounded by a barbed wire-topped, chain-linked fence eight feet in height. A security force and centralized security operations oversee the entire Y-12 Plant. The facility is continuously manned 24 hours per day, 7 days per week by armed guards from the Y-12 Plant Security Department. The perimeter of the facility is patrolled at intervals day and night via a system of patrol roads.

Most gates for pedestrian and vehicular access are manned by armed guards and only authorized personnel are admitted. All individuals entering the Y-12 Plant must be authorized by the Y-12 Plant Security Department.

The units in this permit application are all located within the fully secured (protected) area (see Map 1 in Appendix B-1). Access into the protected area is through continuously manned (24 hours per day) portals where ID badges are needed. Unauthorized personnel are not be permitted into the protected area. 


\section{F-1a(2) Barriers and Means to Control Entry}

Controlled access through guarded portals limits the entry to the units in this permit application. Additional controls such as locked doors prevent the unauthorized entry to the units. See Section F-1a(1) for additional information.

F-1a(2)(a) Barrier

An eight foot high chain-linked fence topped with barbed wire completely surrounds all the units in this permit application. In addition, all the units are within the fully secured (protected) area. See Section F-1a(1) for additional information.

\section{F-1a(2)(b) Means to Control Entry}

Access to the units inside the protected area of the Y-12 Plant is controlled through guarded portals. Doors and gates to the units are locked during off-shift hours or when the authorized facility operator is not present. The gates or doors may be opened on off-shifts and weekends to allow overtime work. See Section F-1a(1) for additional information.

\section{F-1a(3) Warning Signs}

Individual RCRA units at the Y-12 Plant are posted with signs stating:

\section{"Danger--Authorized Personnel Only"}

or a similar message which indicates that only authorized personnel are allowed to enter and that entry onto the active portion can be dangerous. No languages other than English are necessary for the signs at this plant. All signs are located at each entrance and are legible from a distance of at least 25 feet and are visible from all angles of approach.

Signs are located on the sides of each unit that may be approached. They are either mounted on the unit or on boundary control devices at the edge of each unit.

\section{F-1b Waiver}

Not applicable. The Y-12 Plant does not request a waiver of the regulations stated in 40 CFR Part 264.14(a) and Tennessee Rule 1200-1-11.06(2)(e) concerning security of these units.

\section{$\mathrm{F}-1 \mathrm{~b}(1)$ Injury to Intruder}

Not applicable. A waiver is not required; therefore, this section is not applicable. 
F-1b(2) Violation Caused by Intruder

Not applicable. A waiver is not required; therefore, this section is not applicable.

\section{F-2 INSPECTION SCHEDULE}

\section{F-2a General Inspection Requirements}

Because of the diverse activities and the specialized nature of activities at the Y-12 Plant, authority and responsibility for inspections, record-keeping, and remedial actions are delegated among various groups and operating organizations. Inspection activities include coverage of the areas of fire control, emergency and spill response, health and safety, radiological safety, and specialized equipment unique to operations within the Y-12 Plant.

For the purposes of this application, the general inspection schedule for areas and/or equipment related to hazardous waste regulations is given in Appendix F-1. The schedule identifies the types and frequencies of inspections required by RCRA regulations, including monitoring equipment, safety and emergency equipment, security devices, and operating and structural equipment. Operating procedures exist for the units in this package which specify the types of inspection logs, frequency, and record-keeping requirements.

\section{F-2a(1) Types of Problems}

Types of problems to be looked for when inspecting monitoring equipment, safety and emergency equipment, security devices, operating and structural equipment, and areas subject to spills are listed in Appendix F-1.

\section{F-2a(2) Frequency of Inspection}

Inspection frequencies for plant-wide equipment and supplies are included in tables in Appendix F-1.

\section{F-2b Specific Process Inspection Requirements}

Inspection of each unit is conducted according to the inspection schedules in Appendix F-1 and/or the operating procedures. Results of each inspection are recorded on inspection log sheets. Information requested on the log sheets includes the inspector's name, date and time of inspection, items of inspection, types of problems encountered, status of the items, observations, and the date and nature of repairs and remedial actions. Typical problems encountered with each item on the inspection schedule are listed on the log sheet and serve as a reminder to the inspector to ensure a complete inspection. The inspector is required to check the status of each item and to indicate whether its condition is acceptable or 
unacceptable. If the status of a particular item is unacceptable, appropriate and complete information is recorded, including date and nature of repairs and remedial action. Evaluation and/or correction of unacceptable items will be initiated within 24 hours of the inspection. Typical inspection log sheets are provided in Appendix F-2.

\section{F-2b(1) Container Inspection}

Inspections of the container storage areas are conducted according to the general description in Section F-2b and the inspection schedule in Appendix F-1. The container storage areas are inspected on a weekly basis, at a minimum, and recorded on the inspection logs. Typical logs are presented in Appendix F-2.

\section{$\mathrm{F}-2 \mathrm{~b}(2)$ Tank System Inspection}

Not applicable. The units covered in this permit application are not tank systems; therefore, the requirements of this section do not apply.

\section{F-2b(3) Waste Pile Inspection}

Not applicable. The units covered in this permit application are not waste piles; therefore, the requirements for this section do not apply.

\section{F-2b(4) Surface Impoundment Inspection}

Not applicable. The units covered in this permit application are not surface impoundments; therefore, the requirements for this section do not apply.

\section{F-2b(5) Incinerator Inspection}

Not applicable. The units covered in this permit application are not incinerators; therefore, the requirements for this section do not apply.

\section{$\mathrm{F}-2 \mathrm{~b}(6)$ Landfill Inspection}

Not applicable. The units covered in this permit application are not landfills; therefore, the requirements for this section do not apply.

\section{F-2b(7) Land Treatment Inspection}

Not applicable. The units covered in this permit application are not land treatment units; therefore, the requirements for this section do not apply. 


\section{F-2b(8) Miscellaneous Unit Inspections}

Not applicable. The units covered in this permit application are not miscellaneous units; therefore, the requirements for this section do not apply.

F-2b(9) Subpart AA - Inspection Requirements (Organic Emissions from Process Vents) Not applicable. The units in this permit application (containers, tanks) are not required to be monitored for organic emissions from process vents.

F-2b(10) Subpart BB - Inspection Requirements (Organic Emissions from Equipment Leaks at RCRA Units)

Not applicable. The units in this permit application are not required to be monitored or inspected for organic emissions from equipment leaks.

\section{F-2c Remedial Action}

Operational supervisors and responsible technicians are responsible for initiating requests for required maintenance activities when unacceptable conditions or problems are discovered during inspections of these facilities. If inspections reveal that non-emergency maintenance is needed, it will be completed as soon as possible in accordance with a schedule noted in the $\log$, to preclude further damage and reduce the need for emergency repairs. The inspector instructs the responsible maintenance organization on the remedial actions to be taken to correct these deficiencies.

If a problem is imminent or has already occurred during the course of an inspection or any time between inspections, remedial actions will be initiated within 24 hours. In the event of an emergency involving the release of hazardous constituents to the environment, efforts will be directed toward activating the contingency plan, containing the hazard, removing it, and subsequently decontaminating the affected area. Refer to Section G, Contingency Plan, for further details.

\section{F-2d Inspection Log}

Container storage areas are inspected and information is recorded on the typical log sheets shown in Appendix F-2. The logs include spaces for the date of the inspection, identity of the inspector, and the specific items to be inspected and provides for records of remedial action. 
After an inspection, each log sheet is filed at the responsible Department Head's office, and these records are kept in accordance with Recordkeeping, Section J.

\section{F-3 WAIVER OF PREPAREDNESS AND PREVENTION REQUIREMENTS}

The Y-12 Plant does not request a waiver of the preparedness and prevention requirements. Requirements of this subpart are primarily addressed in Sections D, F, and G of this application.

\section{F-3a Equipment Requirements}

Additional internal and external communication systems, emergency equipment, and fire control equipment are discussed in Section G, Contingency Plan.

\section{F-3a(1) Internal Communications}

The Y-12 Plant does not request a waiver of the preparedness and prevention requirements. Requirements of this subpart are primarily addressed in Sections $D, F$, and $G$ of this application.

\section{F-3a(2) External Communications}

The Y-12 Plant does not request a waiver of the preparedness and prevention requirements. Requirements of this subpart are primarily addressed in Sections D, F, and G of this application.

\section{F-3a(3) Emergency Equipment}

The Y-12 Plant does not request a waiver of the preparedness and prevention requirements. Requirements of this subpart are primarily addressed in Sections D, F, and G of this application.

\section{F-3a(4) Water for Fire Control}

The Y-12 Plant does not request a waiver of the preparedness and prevention requirements. Requirements of this subpart are primarily addressed in Sections D, F, and G of this application.

\section{F-3b Aisle Space Requirement}

The Y-12 Plant does not request a waiver of the preparedness and prevention requirements. Requirements of this subpart are primarily addressed in Sections D, F, and G of this application. 


\section{F-4 PREVENTATIVE PROCEDURES, STRUCTURES, AND EQUIPMENT}

\section{F-4a Unloading Operations}

Wastes received at the Cyanide Treatment Unit and Building 9720-12 Container Storage Area are typically delivered in drums, whereas wastes at Buildings 9206 and 9212 Container Storage Areas are generated at that particular location and are contained in tin cans or polyethylene bottles. Drums will normally be on pallets and are unloaded with a forklift or hand jack. In addition, adequate aisle space is maintained at all times. These unloading operations are conducted by trained facility personnel. Further information concerning spill or rupture or other emergency situations is found in Section G, Contingency Plan.

\section{F.4b Run-Off}

Run-off from the units is unlikely since each of the units are enclosed in buildings. In addition, precipitation is prevented from entering all buildings by the presence of roofs.

\section{F-4c Water Supplies}

By preventing run-off as described in F-4b, water supply contamination is prevented. Groundwater contamination is prevented by eliminating the discharge of hazardous materials onto the unprotected ground. Additionally, any spills or leaks would be contained by the design described in F-4b.

\section{F-4d Equipment and Power Failure}

Operations at the units should not be affected if a facility power outage occurs. If the lights, or other equipment should fail, personnel would cease loading, unloading, or transferring waste. The activities can be resumed when power is restored. No problems are anticipated from such a power interruption.

In the event of equipment failure such as truck or forklift breakdown, operations will be halted until a replacement is secured or repairs are completed. The majority of the operation is passive storage and containment. All plant-wide emergency alarms have backup power generators to insure continual power availability.

\section{F-4e Personal Protection Equipment}

The equipment appropriate for employees at specific facilities and areas of the plant is specified by the Plant Industrial Hygiene (IH) and Health Physics (HP) personnel. The plant IH and RP personnel utilize hazardous chemical data, material safety data sheets, and radiological information necessary to determine the appropriate type of personnel protection 
needed. They also consider the characteristics of the waste types to be handled, including toxicity, ignitability, reactivity, corrosivity, routes of exposure, and other information. IH and HP personnel report to the Plant Shift Superintendent whenever the Contingency Plan is implemented, and they assist him in specifying the protective equipment for affected personnel such as fire fighters, rescue teams, spill cleanup personnel, and equipment decontaminators. Available equipment is listed in Section G. See Section H, Personnel Training, for a description of employee training in this subject area.

Personnel exposure to hazardous waste is minimized through the use of protective equipment as well as by safe handling practices. At a minimum, personnel in the storage areas wear safety glasses and safety shoes. If actual handling of hazardous waste is necessary, personnel will wear the above items plus gloves of the appropriate type such as cotton, nitrile rubber, or latex rubber, as specified by the Industrial Hygiene Department for the specific chemical or chemical class being handled as well as work boots with steel inserts and, when needed, respirators. Whenever required, other protective equipment is available, including but not limited to, hard hats with face shields, impermeable coveralls, selfcontained breathing apparatuses, and acid suits. However, the actual requirement for specific safety equipment for the protection of personnel in the event of a spill or leak is determined on a case-by-case basis.

Good handling practices to prevent worker exposure include transferring hazardous wastes carefully, using proper equipment such as drum lifts, funnels, pumps, and pump adapters as well as sealing all containers before moving them. All operations are performed by fully trained laborers under the direction of the operating supervisor or the technician, who are familiar with the personnel protection procedures to be followed for the material being handled.

\section{F-5 PREVENTION OF REACTION OF IGNITABLE, REACTIVE, AND INCOMPATIBLE WASTES}

F-5a Precautions to Prevent Ignition or Reaction of Ignitable or Reactive Wastes

The wastes stored at Buildings 9206, 9212, and 9720-12 are neither reactive nor ignitable.

The wastes stored at the Cyanide Treatment Unit are reactive but not ignitable. Although reactive wastes may not be present at all times, a standard operating procedure for appropriate management of reactive wastes exists and is available for review. Accurate 
identification of waste at the source of generation ensures that wastes are managed so as to prevent reactions, fires, or releases of waste constituents.

Only wastes compatible with the containers are stored. Therefore, no reactions will occur and the only source of ignition will be external to the containers. Nonsparking tools and equipment are used at the Cyanide Treatment Unit and personnel use nonsparking clothing and personnel protective equipment. Sources of ignition or reaction, including open flames, smoking, cutting and welding, hot surfaces, frictional heat, sparks, and spontaneous ignition are prohibited in the area. "No Smoking" signs are conspicuously placed inside the buildings and at all entries. Cutting, welding, or other operations in which a potential hazard exists will only be permitted in this area if a special work permit has been issued. The special work permit will list all precautions necessary to prevent ignition of the waste.

\section{F-5b General Precautions for Handling Ignitable or Reactive Waste and Mixing of Incompatible Waste}

There are no ignitable, reactive, or incompatible wastes accepted at Buildings 9206, 9212, and 9720-12. A compatibility review will be conducted before incompatible wastes are moved into a unit.

There are reactive wastes accepted at the Cyanide Treatment Unit. Sections F-5a, F-5c and F-5d discuss the precautions taken to prevent reactions which:

1. Generate extreme heat or pressure, fire or explosions, or violent reactions;

2. Produce uncontrolled toxic mists, fumes, dusts, or gases in sufficient quantities to threaten human health or the environment;

3. Produce uncontrolled flammable fumes, dusts, or gases in sufficient quantities to pose a risk or fire or explosions;

4. Damage the structural integrity of the device or facility; or

5. Through other like means, threaten human health or the environment.

Segregation of wastes on the basis of generator information minimizes placement of incompatible wastes in the same storage or staging area, and will prevent heat or pressure 
or cause violent reactions or other uncontrolled releases to the environment. All containers remain closed so that fumes, dusts, or gases are not released. Wastes are characterized in accordance with the Waste Analysis Plan in Section C.

\section{F-5c Management of Ignitable or Reactive Wastes in Containers}

The wastes stored at Buildings 9206, 9212, and 9720-12 Container Storage Areas are neither reactive nor ignitable.

The wastes stored at the Cyanide Treatment Unit may be reactive. Section F-5a discusses how reactive waste containers at this facility are protected from materials or conditions which could cause them to react. Wastes are characterized in accordance with the Waste Analysis Plan in Section C. Also, see Section D-1(c)(2).

Map 2 in Appendix B-1, Topographic Map, demonstrates that the Cyanide Treatment Unit is located at least 15 meters ( 50 feet) from the site property boundary.

\section{F-5d Management of Incompatible Waste in Containers}

The wastes stored at Buildings 9206, 9212, 9720-12 and the Cyanide Treatment Unit are not incompatible.

It is the responsibility of the generator to insure that incompatible wastes are not placed in the same container. Adequate aisle space is maintained to allow access for inspection. Containers are opened only when additional waste is added or samples are taken, and they are closed immediately afterward. The unit operators are trained in the proper handling of hazardous waste, including the importance of not adding an incompatible waste to a partially filled container. Wastes are mixed only if it is known from experience that they are compatible and after the contents of each drum are characterized. Hazardous wastes will not be placed into any unwashed container that previously held an incompatible waste or material. The use of properly washed containers, appropriate information, identification of the waste, and knowledge of waste compatibilities will prevent an operator from placing waste into a container that previously held an incompatible waste. Wastes are characterized in accordance with the Waste Analysis Plan in Section C, Waste Characteristics.

\section{F-5e Management of Ignitable or Reactive Wastes in Tanks}

Not applicable. The units in this permit application are not tank systems; therefore, the requirements of this section do not apply. 


\section{F-5f Incompatible Wastes in Tanks}

Not applicable. The units in this permit application are not tank systems; therefore, the requirements of this section do not apply.

\section{F-5g Ignitable or Reactive Wastes in Waste Piles}

Not applicable. The units covered in this permit application are not waste piles; therefore, the requirements for this section do not apply.

\section{F-5h Incompatible Wastes in Waste Piles}

Not applicable. The units covered in this permit application are not waste piles; therefore, the requirements for this section do not apply.

\section{F-5i Ignitable or Reactive Wastes in Surface Impoundments}

Not applicable. The units covered in this permit application are not surface impoundments; therefore, the requirements for this section do not apply.

\section{F-5j Incompatible Wastes in Surface Impoundments}

Not applicable. The units covered in this permit application are not surface impoundments; therefore, the requirements for this section do not apply.

\section{F-5k Ignitable or Reactive Wastes in Landfills}

Not applicable. The units covered in this permit application are not hazardous waste landfills; therefore, the requirements for this section do not apply.

\section{F-51 Incompatible Wastes in Landfills}

Not applicable. The units covered in this permit application are not hazardous waste landfills; therefore, the requirements for this section do not apply.

\section{F-5m Ignitable or Reactive Wastes in Land Treatment}

Not applicable. The units covered in this permit application are not land treatment units; therefore, the requirements for this section do not apply.

\section{F-5n Incompatible Wastes in Land Treatment}

Not applicable. The units covered in this permit application are not land treatment units; therefore, the requirements for this section do not apply. 
Y/TS-1015/R2

Resource Conservation and Recovery Act (RCRA) General Contingency Plan for Hazardous Waste Treatment, Storage, and Disposal Units at the Oak Ridge Y-12 Plant

Environmental Management Department

Health, Safety, Environment, and Accountability Organization

August 1994
Prepared by the

Oak Ridge Y-12 Plant

Oak Ridge, Tennessee 37831

Managed by

MARTIN MARIETTA ENERGY SYSTEMS, INC. for the

U.S. DEPARTMENT OF ENERGY under contract DE-AC05-84OR21400 


\section{DISCLAMMER}

This report was prepared as an account of work sponsored by an agency of the United States Government. Neither the United States Government nor any agency thereof, nor any of their employees, makes any warranty, express or implied, or assumes any legal liability or responsibility for the accuracy, completeness, or usefulnass of any information, apparatus, product, or process disclosed, or represents that its use would not infringe privately owned rights. Reference herein to any specific commercial product, process, or service by trade name, trademark, manufacturer, or otherwise, does not necessarily constitute or imply its endorsement, recommendation, or favoring by the United States Government or any agency thereof. The views and opinions of authors expressed herein do not necessarily state or reflact those of the United States Government or any agency thereof. 


\title{
Resource Conservation and Recovery Act (RCRA) Contingency Plan for \\ Hazardous Waste Treatment, Storage, and Disposal Units at the Oak Ridge Y-12 Plant
}

\section{Environmental Management Department}

Health, Safety, Environment, and Accountability Organization

\author{
Prepared by the \\ Oak Ridge Y-12 Plant \\ Oak Ridge, Tennessee 37831 \\ Managed by \\ MARTIN MARIETTA ENERGY SYSTEMS, INC. \\ for the \\ U.S. DEPARTMENT OF ENERGY \\ under contract DE-AC05-84OR21400
}





\section{RESOURCE CONSERVATION AND RECOVERY ACT (RCRA) \\ GENERAL CONTINGENCY PLAN FOR \\ HAZARDOUS WASTE TREATMENT, STORAGE, AND DISPOSAL UNTTS \\ AT THE OAK RIDGE Y-12 PLANT}

\section{GENERAL FACILITY DESCRIPTION}

The Oak Ridge Y-12 Plant was built by the U.S. Army Corps of Engineers in 1943 as part of the Manhattan Project and given the original mission of separating the fissionable isotope of uranium by the electromagnetic process. After World War II, the electromagnetic process was . discontinued in favor of the more economical gaseous diffusion process. In recent years, the Y-12 Plant staff has developed this facility into a highly sophisticated manufacturing and developmental engineering organization.

The U.S. Department of Energy (DOE) owns and operates the Y-12 Plant. Martin Marietta Energy Systems, Inc., co-operates and manages the Y-12 Plant. Since 1984, the facility has been managed by Martin Marietta Energy Systems, Inc. personnel, under a prime contract with the U.S. DOE. The contract is administered by personnel at the DOE, Oak Ridge Operations.

The Y-12 Plant occupies approximately 800 acres in Anderson County, Tennessee, and is located southwest of the city of Oak Ridge. The site employs approximately 4,000 people, including employees of the Oak Ridge National Laboratory assigned to the Y-12 Plant. Two surface streams, East Fork Poplar Creek and Bear Creek, border the facility on the south, east, and southwest sides of the plant. There is access to the Y-12 Plant, controlled on Bear Creek Road, on the north side of the facility, indirect access from Scarboro Road on the east side of the facility, and indirect access to the facility on the south side via Bethel Valley Road. A controlled access road from Bethel Valley Road by way of Mt. Vernon Road is located on the southwest side of the site.

It is the mission of the Y-12 Plant to serve as a key manufacturing technology center for the development and demonstration of unique materials, components, and services of importance to the DOE and the nation. This is accomplished through the reclamation and storage of nuclear materials, manufacture of nuclear materials, manufacture of components for the defense capabilities of the nation, support to national security, programs, and services provided to other customers as approved by DOE.

\section{GENERAL INFORMATION}

The Y-12 RCRA Contingency Plan will be continually reviewed and revised if any of the following occur: the facility permit is revised, the plan is inadequate in an emergency, the procedures herein can be improved, the operations of the facility change in a way that alters the 
plan, the emergency coordinator changes, or the emergency equipment list changes. Copies of the Y-12 Emergency Management Plan are available at the Plant Shift Superintendent's Office and the Emergency Management Office. This document serves to supplement the Y-12 Emergency Management Plan to be appropriate for all RCRA hazardous waste treatment, storage, or disposal units. The 90-day accumulation areas at the $\mathrm{Y}-12$ Plant have a separate contingency supplement as required by RCRA and are separate from this supplement.

The facility name, address, identification number, and owner/operator name are provided below:

\author{
U.S. Department of Energy Oak Ridge Y-12 Plant \\ Bear Creek Road \\ Post Office Box 2001 \\ Oak Ridge, Tennessee 37831-8555 \\ EPA ID TN3 89-009-0001
}

Owned and operated by U.S. Department of Energy

Managed and co-operated by Martin Marietta Energy Systems, Inc.

The overall layout of the Y-12 Plant and the location of RCRA units are shown in Figure 1, "Y-12 Plant RCRA Waste Unit Locations." Figure 2, "Y-12 Plant Emergency Facilities

Directory," shows the locations of assembly stations, boundaries, and access controls to the plant. Figure 3, "Y-12 Plant Bear Creek Burial Ground Waste Unit Map," shows the units located at the west end of the plant, Gamewell alarm box locations, boundaries, and access controls to these areas. Figure 4, "Y-12 Plant Evacuation Routes", shows a typical evacuation route that could be used to evacuate the Y-12 Plant in the event of an emergency. The Plant Emergency Director (PED) will ultimately determine and direct all personnel to the appropriate evacuation routes.

\title{
EMERGENCY COORDINATORS
}

The emergency coordinator at the Y-12 Plant is the PED. The Y-12 Plant has several Plant Shift Superintendents (PSS) who share the responsibilities of the PED. At least one PSS is on duty 24 hours per day, every day of the year, and can be reached at (615) 574-7172 at the Emergency Operations Center (EOC) in Building 9706-2. The alternate EOC is located in Building 9709 and the phones are transferred if the operations are being conducted at this building. The PSS on duty is responsible for providing continuous plantwide emergency direction as the PED. If the PED is incapacitated during an emergency, the Site Security Commander on duty is his alternate until another PSS can report to the scene. The PSS, or alternate, has access to names, telephone numbers, and addresses of all emergency personnel and will determine who must be contacted to provide emergency activity support. 
The duties of the PED as the Emergency Coordinator include:

- Receiving notice that an incident has occurred;

- Evaluating the threat;

- Activating internal alarm systems to notify or evacuate personnel, if appropriate;

- Proceeding immediately to obtain information concerning released materials and initiating appropriate activities for characterizing and abating the release;

- Ensuring that necessary on-site notifications are made;

- Performing an assessment of the potential for off-site effects upon the public health and environment and notifying DOE-Oak Ridge EOC of the same;

- Initiating and directing a plan of action;

- Mobilizing sufficient forces, including technical assistance, to respond to the emergency at hand;

- Directing the overall effort to respond to plant emergencies in such a way as to ensure that all emergency groups, both local and plantwide function as a team.

- Delegating authority in any capacity necessary if the need arises during an emergency;

- Authorizing all rescue efforts requiring any employee experiencing illness or injury;

- Seeing that off-site medical facilities are notified immediately when a seriously ill or injured patient is en route, and provide the nature of the injury or illness;

- Ensuring that a medical department staff member, a supervisor, or someone knowledgeable as to the circumstances or acquainted with the details of any serious accident or illness accompanies the patient to the emergency room;

- Determining the accessibility of plant areas after an accident and authorizing reentry of evacuated areas; 
- Under special conditions, requesting the designation of a technical group to assist in evaluating the advisability of reentry;

- Terminating emergency status when the threat is entirely gone;

- Authorizing, when applicable, the sounding of the "all clear" signal at the termination of an emergency; and

- Restoring the plant to normal operations.

The names and work numbers of the PSS are provided below:

$\begin{array}{lcc}\text { Name } & \text { Building Location } & \text { Work Phone } \\ \text { W. M. Bradley } & 9706-2 & \text { (615) } 574-7172 \\ \text { L. K. Brooks } & 9706-2 & (615) 574-7172 \\ \text { J. D. Chapman } & 9706-2 & (615) 574-7172 \\ \text { E. Manis } & 9706-2 & (615) 574-7172 \\ \text { P. C. Norris } & 9706-2 & (615) 574-7172 \\ \text { C. L. Beeler } & 9706-2 & (615) 574-7172 \\ \text { G. L. Calvert } & 9706-2 & (615) 574-7172\end{array}$

Emergency resource books containing lists of emergency response telephone numbers (Emergency Response Organization personnel, facilities, off-site agencies, outside support organizations, etc.) are readily available to the PED in the EOC and alternate EOC. Telephone listings are revised as changes occur. In addition, a quarterly review is conducted by the Emergency Preparedness Operations Department Manager. The PED has the authority to commit the necessary resources to implement the contingency plan. 


\section{IMPLEMENTATION}

The decision to implement this contingency plan, as part of the Emergency Management Plan, depends upon whether an imminent or actual incident could threaten human health or the environment.

The contingency plan will be implemented by the PED in the following situations:

- A fire and/or explosion occurs, such that:

- The potential for human injury exists;

- Toxic fumes that could endanger human health or the environment are released;

- The fire could spread on site or off site and possibly ignite other flammable materials or cause heat-induced explosions;

- The use of water and/or chemical fire suppressants could result in contaminated runoff that could endanger human health or the environment; and/or

- An imminent danger exists that an explosion could ignite other hazardous wastes at the facility and possibly result in the release of toxic materials.

- A spill or release of a hazardous material occurs such that:

- The spill could result in release of flammable liquids or vapors, thus causing a fire or gas explosion hazard;

- The spill could cause the release of toxic liquids or fumes that could endanger human health or the environment; and/or

- The spill cannot be contained on site, resulting in off-site soil contamination and/or ground or surface water pollution that could endanger human health or the environment.

Many ways of discovering a spill or release of chemicals are possible. These include: routine and scheduled inspections of process equipment and material storage areas; unusual or strong chemical odors which may indicate a leak; and instrumentation such as level alarms, automatic sump pumps, and $\mathrm{pH}$ meters which may also reveal chemical spills or system malfunctions.

\section{CONTROL PROCEDURES - INCIDENT COMMANDER}

The incident commander is defined as the person assuming command and control of emergency response at the scene of the incident. The incident commander will be the operations supervisor on duty for a specific unit or, in the absence of a supervisor, the first arriving emergency response officer designated by the PED. The incident commander will be responsible for the following:

- Initial assessment of the incident scene to the PED;

- Establishing control and setting up the command post for emergency response; 
- Initial evaluation of the magnitude of the problem;

- Evacuation of personnel from immediate danger;

- Arranging for assembly, organization, and briefing of emergency response personnel who have been summoned;

- Providing updated information on conditions, progress of response, and additional manpower or equipment needs to the PED;

- Directing operational changes needed (e.g., shutting off process flows);

- Implementing applicable prearranged plans and procedures; and

- Continuing to provide incident control until relieved by an alternate incident commander.

The following actions will be taken in areas affected by a fire or explosion:

1. Work in the affected areas will be shut down immediately.

2. Feedlines and additional equipment will be shut down, as necessary and practical.

3. The PED will be contacted.

4. The area will be cleared of all personnel not actively involved in fighting the fire. These persons are to report to the designated assembly points for accountability.

5. All injured persons will be removed, and medical treatment will be administered by Medical Department personnel with outside assistance, as required.

\section{EMERGENCY RESPONSE PROCEDURES - EMERGENCY COORDINATOR}

The PED is responsible for the overall direction of emergency response efforts as follows:

- Directs emergency service units and local emergency squads.

- Ensures that the incident commander at the scene of the emergency, evaluates:

- Radiation and general safety situations as they affect the immediate and adjacent areas,

- Need for interrupting utility services such as process water, ventilation, oxygen, natural gas, and electricity, and 
- Need for operational changes.

- Considers the need for and arranges for any large-scale alert, evacuation, general alert, invocation of mutual assistance agreements, and procurement of additional emergency personnel or emergency equipment.

- Keeps Y-12 Plant management and appropriate staff groups informed.

- Determines when the emergency is over, and orders the "all clear" signal.

The Emergency Management Department staff is responsible for:

- Y-12 Plant-wide emergency planning.

- Updating the Emergency Management Plan.

- Planning for practice exercises.

- Coordinating the organization and training of emergency service units and local emergency organizations.

- Ensuring that plans are in place for receiving and evaluating emergencies.

- Ensuring that plans are in place for activating internal alarm systems to alert/evacuate personnel.

- Planning coordination for the emergency response team; determine if outside assistance is required.

- Ensuring that plans are in place to report incidents to personnel at the DOE, Oak Ridge Operations in accordance with DOE Order 5000.3A "Occurrence and Processing of Operations Information."

\section{Notification}

The employee discovering a potential emergency incident will notify his immediate supervisor and/or the PED. The PED will immediately activate the internal alarm system to notify or evacuate personnel, if appropriate. The PED will also notify the Plant Manager, the Production Manager, the Environmental Coordinator, and Organization Managers of the operations involved. 
In the event that outside assistance is required, the PED will notify appropriate state and/or emergency response agencies.

\section{Identification of Hazardous Materials}

The incident commander will immediately attempt to identify the character, exact source, amount, and aerial extent of the material involved in the fire or release. The initial identification method will be by visual analysis of the material and location of the release. Plant records, including inventories and process and waste log sheets, are available at the operating department offices of the RCRA units to aid in estimating the composition and quantity of released material. In the event of a spill, a sample of the spilled material is taken if the material enters a storm drain, there is some question as to the identity of the material, or the material is suspected to contain polychlorinated biphenyls (PCBs). The Health, Safety, Environment, and Accountability Organization staff will sample to verify hazardous material identification, determine boundaries of contaminated areas and contaminant concentrations, and verify proper cleanup after cleanup activities are completed.

Information such as storm sewer locations and topographic information is available to support the PED in the process of identifying potential flow/contamination paths and determine appropriate control actions.

\section{Hazard Assessment}

Assessment of possible hazards to human health or the environment will be made using the following methods:

1. Process knowledge (i.e., knowledge of the nature of waste materials released);

2. Review of Material Safety Data Sheets, if available;

3. Chemical analysis/monitoring data;

4. Results of modeling for releases to air, surface water, or groundwater; and

5. Specific health-based and environmental criteria or limits which may be exceeded.

Based on the hazard assessment, evacuation of the immediate unit area, entire facility, or local areas outside the facility may be necessary.

\section{Off-Site Notification/Evacuation}

The Y-12 Emergency Management Plan describes the methods used for notification of Y-12 emergency response personnel and appropriate federal, state, and local emergency response centers. Individuals or groups that may be notified include, but are not limited to, the following: 
- DOE Oak Ridge Operations EOC,

- DOE Headquarters EOC (through the Oak Ridge Operations EOC voice bridge),

- Tennessee Emergency Management Agency,

- National Response Center,

- Local Emergency Planning Councils,

- Affected county notification points,

- City of Oak Ridge (Anderson County),

- Regional U.S. Environmental Protection Agency, and

- Other agencies as required by regulatory guidance.

Evacuation of nonessential personnel is ordered by the PED if it is determined that a threat to the safety of plant personnel exists. Evacuation routes will be determined by the PED; however typical evacuation routes are shown in Figure 4.

\section{Prevention of Recurrence or Spread}

After incident mitigation, a recovery manager will be appointed to return the incident scene to preincident conditions and analyze the root cause of the incident.

\section{Storage and Treatment of Released Material}

Any hazardous materials that results from a release, fire, or explosion at the Y-12 Plant will be contained, removed, and placed in 55-gallon drums (or smaller containers if appropriate).

Leaking or damaged containers will be placed in 85 -gallon overpack drums so they can be stored until treatment or disposal arrangements are finalized.

Contaminated absorbent materials, protective clothing, and other disposable material used in remediation of the emergency and subsequent decontamination activities will be placed in 55-gallon drums and stored at a RCRA storage unit pending treatment or disposal. These items will be handled with the same degree of caution as the wastes themselves so that public health and the environment are not further threatened.

Immediately after an emergency, the emergency coordinator will make arrangements for treatment, storage, or disposal of recovered waste, contaminated soil, surface water, or any other contaminated material. Emergency and spill response equipment available for cleanup, storage, and treatment are identified in the Y-12 Emergency Management Plan.

\section{Incompatible Waste}

In order to prevent reactions caused by proximity of incompatible substances, wastes which have been spilled or released must be segregated from other wastes or materials which are incompatible. It is a duty of the Spill Response Coordinator to ensure that wastes which may be 
incompatible with the released material are not treated, stored, or disposed of in the vicinity of the spill or fire until cleanup procedures are completed.

Incompatible wastes are unlikely to be treated, stored, or located in the affected areas until cleanup is completed because of the waste segregation practices used at the facility. If possible, no additional wastes will be stored in the affected area until the cleanup is completed. If waste storage there is necessary, wastes will be placed only in those areas where no incompatible wastes are present.

\section{Postemergency Equipment Maintenance}

All emergency response elements will ensure that team equipment is properly decontaminated, supplies are restocked, and the team is returned to preemergency readiness.

\section{Container Spills and Leakage}

In the event of a hazardous material spill or release, the following general procedures will be used for rapid and safe response and control of the situation. Spills or releases and impending spills or releases discovered during routine inspections will be handled in the same manner as described below for spill and release emergencies. These are general guidelines, and circumstances may dictate some alterations to these procedures.

If an employee discovers a chemical spill or process upset resulting in a hazardous material release, he or she will immediately report it to the area supervisor. The area supervisor or the employee will contact the PED. When contacted, the PED will obtain information pertaining to the following:

1. The material spilled or released,

2. Location and source of the release or spillage of hazardous material,

3. An estimate of the quantity released and the rate at which it is being released,

4. The direction in which the spill, vapor, or smoke release is heading,

5. Any injuries involved, and

6. Fire and/or explosion or possibility of these events.

This information will help the PED to assess the magnitude and potential seriousness of the spill or release. The PED will contact and deploy the necessary in-plant personnel. If additional assistance is required, the PED will also contact the other Oak Ridge plants that have agreed to provide assistance and the agencies discussed in the Coordination Agreements section of this plan.

The initial response to any emergency will be to protect human health and safety, and then the 
environment. Identification, containment, treatment, and disposal assessment will be the secondary responses.

Medical assistance for injured persons will be obtained from the Y-12 Health Services staff.

Cleanup personnel summoned by the PED will don protective clothing and equipment, as specified by the Health, Safety, Environment, and Accountability Organization staff. If a flammable waste is involved, all ignition sources will be removed, and spark and explosion-proof equipment and clothing will be used for containment and cleanup activities. If possible, cleanup personnel will try to stop the leak. Special materials, such as tank patch kits, will be kept on hand for temporary repairs. All surrounding materials that could be reactive with the waste materials will be removed. The major components of the waste will be determined.

Absorbent pads, booms, earth, sandbags, sand, and other inert materials will be used to contain, divert, and clean up a spill if it has not been contained by a dike or sump. Sewer plugs are available, if required, to isolate a spill. Spills contained within a dike or sump may be pumped back into the appropriate storage tank or drum, if it is structurally sound. All containment and cleanup materials will be placed in drums for proper disposal. Some itens, such as absorbent rags or booms, may have to be cut up. All recovered liquid wastes and contaminated soil that cannot be returned to their original storage tanks or containers will be placed in drums for removal to an approved storage or disposal site.

Most tank and container spills and leaks are contained within the dikes and sumps provided in the tank and container areas. Small spills occurring in a diked area are directed to the sump provided in that area. Immediately after the spill is detected, the Waste Management Organization staff will be summoned to remove any standing liquids (as described above) and arrange to have the spilled material taken to a unit approved to handle that particular waste. If necessary, a portable sump pump will be used to pump the diluted waste material into 55-gallon drums. The transfer of the spilled material will be performed within 24 hours or at the earliest practical time if it is demonstrated that the material cannot be transferred within 24 hours.

If, for some reason, a chemical spill is not contained within a dike or sump area, an appropriately sized area of isolation will be established around the spill. The size of the area will generally depend on the size of the spill and the materials involved. An area at least 50 feet in all directions will be isolated. For large spills, an area at least 100 feet in all directions will be isolated. When any spill occurs, only those persons involved in overseeing or performing emergency operations will be allowed within the designated hazard area. If possible, the area will be roped or otherwise blocked off. All persons not actively involved in managing the spill will be kept upwind. 
If the PED determines that Y-12 and the other DOE plants are unable to handle the emergency, then local, state, and federal authorities will be notified of the situation. When necessary, evacuation of all potentially affected plant areas will begin as soon as possible.

All emergency equipment used for spill management must be cleaned by the responsible personnel so that it is fit for use prior to resumption of plant operations in the affected areas.

Tank Spills and Leakage

In the event of a hazardous material spill or release, the procedures described for container spills and leakage apply for tank releases.

\section{EMERGENCY EQUIPMENT}

A listing of typical emergency and spill response equipment for the Y-12 Plant is listed in Appendix B. The specific emergency and spill response equipment is provided in the $\mathrm{Y}-12$ Emergency Management Plan. In addition, emergency equipment is maintained at the units in this plan for minor releases which include, but is not limited to, absorbent material, fire extinguishers, shovels, shoe scuffs, gloves, eye protection, and protective clothing. The inspection lists and frequency for inspection of the spill response equipment at the units are presented in the Y-12 Emergency Management Plan.

\section{COORDINATION AGREEMENTS}

The Y-12 Emergency Management Plan details all coordination agreements currently held with local agencies. These agreements provide for emergency assistance to other participants in the event of major fires, explosions, natural disasters accidents involving hazardous/radiological materials, and situations that could endanger life, public safety, or the environment or that have an extensive area impact. This agreement includes the K-25 Site, the Y-12 Plant, and ORNL. Examples of these agreements are provided in Appendix C. A copy of this plan has been provided to all mutual aid organizations. Designated emergency coordinators will commit the necessary resources to implement the contingency plan. The PED will request assistance, when necessary, from other DOE sites. Each plant will have authority to provide emergency equipment and personnel upon request. The Emergency Directors' telephone numbers are:

$\begin{array}{ll}\text { Y-12 Plant } & 615-574-7172 \\ \text { K-25 Site } & 615-574-3282 \\ \text { ORNL } & 615-574-6606 \\ \text { DOE Security } & 615-576-1004\end{array}$




\section{EVACUATION PLAN}

All emergencies at the Y-12 Plant warrant prompt and deliberate action. Criteria for evacuation have been established. The PED is responsible for determining whether evacuation is necessary. The Y-12 Emergency Management Plan contains details of this criteria. If evacuation of the Y-12 Plant is necessary evacuation routes that would typically be used are illustrated in Figure 4.

\section{REQUIRED REPORTS}

The PED will note in the operating record the time, date, and details of any incident which required implementation of the Contingency Plan. Internal reports will be filed as required by DOE and Martin Marietta Energy Systems, Inc., personnel.

Within 15 days after the incident, personnel from the Y-12 Plant will submit a written report on the incident which required implementation of the Contingency Plan to the DOE staff for review and transmittal to the Commissioner of the Tennessee Department of Environment and Conservation, as required by Tennessee Rule 1200-1-11-.06(5)(c). The report will include:

- Name, address, and telephone number of the owner or operator;

- Name, address, and telephone number of the facility;

- Date, time, and type of incident (e.g., fire, explosion);

- Name and quantity of material(s) involved;

- The extent of injuries, if any;

- An assessment of actual or potential hazards to public health or the environment, where this is applicable; and

- Estimated quantity and disposition of recovered material that resulted from the incident. 



\section{APPENDIX A}

\section{UNIT-SPECIFIC EMERGENCY and WASTE DESCRIPTIONS}

This section summarizes unit-specific contingency and waste description information for the treatment, storage, and disposal units below.

\section{Cyanide Treatment Unit}

The Cyanide Treatment Unit is located in Building 9201-5N. The nearest Gamewell box is located on the south wall outside of Building 9201-5N. This Gamewell box is connected to the existing plant Gamewell Fire Alarm System and Plant Monitoring System. A telephone is available in the room where the unit is located. An eyewash and safety shower station is also available in this room. Two-way radios are available to communicate with the PED office, if emergency assistance is necessary.

The Cyanide Treatment Unit treats cyanide wastes that have been generated in various plant operations.

\section{Kerr Hollow Quarry Treatment Unit}

The Kerr Hollow Quarry Treatment Unit is located 0.4 miles west of the intersection of Scarboro Road and Bethel Valley Road on the north side of Bethel Valley Road. A public address system is installed at this unit, along with closed circuit television. Two-way radios are used, and a telephone is available in the guard shack for communication with the PED office, if emergency assistance is required.

This unit no longer receives hazardous waste. Closure of this unit is complete and approval is pending.

\section{Garage Underground Tanks}

The Garage Underground Tanks are located near Building 9737. A Gamewell box is located nearby at the service station and connected to the existing plant Gamewell Fire Alarm System and Plant Monitoring System. Two-way radios are used by personnel at this site to provide communication with the PED office, if emergency assistance is needed. A phone is available in Building 9712 East End Garage, as well as an eyewash/safety shower station.

This unit no longer receives hazardous waste. It is currently undergoing closure.

\section{Walk-In Pits}

The Walk-In Pits are located north of Disposal Area Remedial Action (DARA) Solids Storage 
Unit, in the Bear Creek Burial Grounds. The nearest available phone, Gamewell box, eyewash and safety shower are located at the DARA Liquid Storage and Treatment Unit. The Gamewell box is connected to the existing plant Gamewell Fire Alarm System and Plant Monitoring System. Two-way radios are used for communication with the PED office, if emergency assistance is needed.

Closure of this unit is complete and approval is pending.

\section{Interim Drum Yard}

Interim Drum Yard is located near Building 9720-32. The nearest available Gamewell box is located on the east end of Building 9720-32. This Gamewell box is connected to the existing plant Gamewell Fire Alarm System and the Plant Monitoring System. A portable eyewash and safety shower are used by personnel at this unit. Two-way radios are used for communication with the PED if emergency assistance is needed, and a phone is also available nearby in Building 9401-5.

This unit no longer receives hazardous waste and the closure plan has been submitted for this unit. Approval and closure activities are pending.

\section{Building 9720-9. Storage Unit}

Building 9720-9 is located on Third Street. Two Gamewell boxes are located at the east and west sides of the building and connected to the existing plant Gamewell Fire Alarm System and the Plant Monitoring System. Telephones and two-way radios are also used by personnel to provide communication with the PED office, if emergency assistance is needed. Two eyewash/safety showers are provided and located at the west and south sides of the building.

This unit provides storage for hazardous, nonhazardous, and mixed waste. Waste is stored at this unit until waste analysis and appropriate treatment or disposal can be arranged. All classes of RCRA wastes, except for $\mathrm{K}$-listed wastes, and hazardous wastes from specific sources (40 CFR Part 261.32 and Tennessee Rule 1200-1-11.02(4)) are stored in this unit.

\section{RCRA and Mixed Waste Storage and Staging Unit, Building 9720-31}

Building 9720-31 is located on West Third Street. Two Gamewell boxes are located on the east and west side of the building and connected to the existing plant Gamewell Fire Alarm System and the Plant Monitoring System. Telephones and two-way radios are also used by personnel to provide communication with the PED offices, if emergency assistance is needed.

This unit is used to store solids, liquids, and sludge wastes, which typically are hazardous, nonhazardous, or mixed waste. It is a one-story structure constructed of light-weight, concrete 
block, masonry walls and partitions. The building is partitioned into fifteen rooms: one supply room, seven staging rooms, and seven storage rooms. Normally, the largest containers in any of the staging or storage rooms are 55-gallon drums, however, 85-gallon overpack containers may be used to store waste. Waste stored in the staging and storage rooms may be in Department of Transportation-specification containers or the original product containers.

\section{Building 9811-1 RCRA Tank Storage Unit (OD-7)}

Building 9811-1 RCRA Tank Storage Unit is located at the intersection of West Second Street and $\mathrm{K}$ Road. It is served by an auxiliary fire alarm pull box which is inside the south side of Building 9811-1. Additional alarm boxes are located at Building 9720-16, and at the intersection of Second Street and K Road which is southwest of OD-7. These boxes are connected to the existing plant Gamewell Fire Alarm System and the Plant Monitoring System. Two fire hydrants are located near this unit. One is approximately 20 feet north of the RCRA Storage Unit, and the second hydrant is located approximately 75 feet southwest. Telephones and two-way radios are used by personnel to provide communication with the PED office, if emergency assistance is needed. A telephone is also located in the OD-7 operator trailer for communication with emergency personnel. A safety shower/eyewash assembly is planned for installation at a future date at the drum loading/unloading area and the transfer station as part of an OD-7 upgrade project.

This unit is designated as the primary storage unit for nonignitable and nonreactive, mixed waste oils and solvents. Contaminated oils, nonchlorinated solvents, some toxicity characteristic wastes, and used oil may also be accepted at the unit. The storage tank area of the unit consists of a 51x 58-foot, concrete, diked area. Positioned within the diked area are four, 30,000-gallon tanks and one, 10,000-gallon tank. Two additional 10,000-gallon tanks will be installed at a future date.

\section{Building 9811-1 - RCRA Container Storage Unit (OD-8)}

Building 9811-1 is located at the intersection of West Second Street and K Road. A Gamewell box is located on the south side of the building (inside) and connected to the existing plant Gamewell Fire Alarm System and the Plant Monitoring System. A safety shower/eyewash is located at the north side of the building.

This unit is used primarily as a storage area for containerized liquid waste until the waste has been characterized to allow transfer to other treatment, storage, or disposal units. Contaminated liquids with a concentration of greater than $50 \mathrm{ppm}$ PCBs will not be stored at this unit.

\section{Waste Oil/Solvent Storage Unit (OD-9)}

The Waste Oil/Solvent Storage Unit is located on Old Bear Creek Road, and served by an auxiliary fire alarm pull box. The Gamewell box is connected to the existing plant Gamewell Fire 
Alarm System and the Plant Monitoring System. Two fire hydrants are available for use and are freeze-proof. One hydrant is located along the site access road approximately 60 feet east of the truck entrance to the building. The second hydrant is on the north side of Old Bear Creek Road, near the site egress road, approximately 100 feet southwest of the facility truck exit area.

Telephones and two-way radios are used by personnel to provide communication with the PED office, if emergency assistance is needed. Two safety shower/eyewash assemblies, both of which are freeze-proof, are located at the northeast corner of the tank area (in the truck loading pad adjacent to the drum storage area) and on the floor of the containment structure. Potable water is supplied to both units and is identified by green lights installed above each unit. The eye/face units are push bar operated with stay-open valves.

This unit typically receives and stores nonignitable and nonreactive mixed waste oil/solvents that may contain water, be contaminated with PCBs greater than $50 \mathrm{ppm}$, and contain chlorinated organic solvents. This unit may also store used oil. The liquid wastes are stored here in tanks and drums until sufficient volume is accumulated for transportation to an outside facility for recovery or disposal.

\section{Liquid Organic Solvent Storage Unit (OD-10)}

The Liquid Organic Solvent Storage Unit is located in the Bear Creek Burial Grounds, and served by an auxiliary fire alarm pull box which is located approximately 40 feet south of the unit. An additional Gamewell box is accessible at the intersection of Bear Creek Road and the access road to OD-10. This Gamewell box is connected to the existing plant Gamewell Fire Alarm System and Plant Monitoring System. A freeze-proof fire hydrant is located approximately 200 feet south of the unit. Two-way radios provide communication between the unit and the PED office, if emergency assistance is necessary. Three safety shower/eyewash assemblies are provided at $O D-10$, which includes two located in the staging area (north and south side) and the third located in the tank area. Potable water is supplied to these assemblies, which are push bar operated with stay-open valves. Each unit is identified by a green light installed above each assembly.

This unit receives and stores liquid organic wastes generated in the Y-12 Plant. These wastes typically include waste oil and combustible and flammable waste liquids that may be defined as mixed waste or used oil. The liquids received at this unit are pumped into the tanks for storage until sufficient quantity is accumulated for final disposal or recovery.

\section{Building 9409-5 Storage Unit}

The Building 9409-5 Storage Unit is located on Third Street. The nearest Gamewell box is located in Building 9409-2. This Gamewell box is connected to the existing plant Gamewell Fire Alarm System and Plant Monitoring System. No phone is available, and this unit is no longer in 
service. Two-way radios are used to communicate with the PED office, if emergency assistance is needed.

This unit no longer receives hazardous waste. It is currently undergoing closure.

\section{East Chestnut Ridge Waste Pile}

The East Chestnut Ridge Waste Pile is located on South Patrol Road. Two-way radios are used to communicate with the PED office, if emergency assistance is required. The nearest Gamewell box is located southwest of the unit across the street from the Containerized Waste Storage Area. This Gamewell box is connected to the existing plant Gamewell Fire Alarm System and Plant Monitoring System.

This waste pile is used for the storage of soils and spoils contaminated with hazardous and lowlevel radioactive materials, asbestos, and roofing materials from the closure of RCRA sites at the Y-12 Plant. Additional contaminated soils may be moved to the East Chestnut Ridge Waste Pile if excavation activities continue at the $\mathrm{Y}-12$ Plant.

\section{Containerized Waste Storage Area (CWSA)}

The CWSA is located on South Patrol Road. A Gamewell box is located south, directly across the street from the CWSA, and is connected to the existing plant Gamewell Fire Alarm System and the Plant Monitoring System. Two-way radios are also used to provide communication with the PED office, if emergency assistance is needed. A portable safety shower/eyewash is provided during operations.

The CWSA consists of three concrete pads measuring 170 feet long and 50 feet wide. The central and eastern concrete pads are covered by open-sided dome tents and store hazardous, nonhazardous, or mixed wastes. The western concrete pad is not covered, and no wastes are stored there. Each pad has a one-foot impermeable dike surrounding it to contain spills. The pads and dikes are sloped toward a 60-gallon sump located on the southeast corner of the pads to catch spilled material and manage rainwater.

\section{Classified Container Storage Unit. Building 9720-25}

Building $9720-25$ is located on M Street. Two Gamewell boxes are located inside the building and connected to the existing plant Gamewell Fire Alarm System and the Plant Monitoring System. Telephones and two-way radios are also used by personnel to provide communication with the PED office, if emergency assistance is needed.

Building $9720-25$ is a storage unit designed for storage of classified wastes generated at the Y-12 Plant. The wastes include materials, fabricated parts, and containers which have been 
security classified to prevent dissemination of potentially vital information. Storage in one part of this unit of classified waste, contaminated with hazardous constituents, is necessary due to present uncertainties as to final modes of treatment and/or disposal of classified and/or hazardous waste materials. The stored materials include hazardous and mixed wastes.

\section{Oil Land Farm Soils Containment Pad}

The Oil Land Farm Soils Containment Pad is located west of the main plant area on Bear Creek Road. A telephone is available nearby in the sampling trailer, or two-way radios are used to communicate with the PED office, if emergency assistance is needed. The nearest eyewash/safety shower station is located at the Liquid Organic Solvent Storage Unit, which lies west of this location on Bear Creek Road.

This unit provides storage for contaminated soils and excavation wastes that were generated during RCRA closure of the Oil Land Farm and Oil Retention Ponds at the Y-12 Plant. These soils were contaminated with hazardous, mixed, or radioactive wastes. Contaminants include organics, heavy metals, pesticides, $\mathrm{PCBs}$, and radionuclides. The unit provides interim storage for excavation wastes pending scheduling of the soils for final treatment or disposal.

\section{DARA Solids Storage Unit}

The DARA Solids Storage Unit is located west of the main plant area on Bear Creek Road. A Gamewell box is located near the unloading pad adjacent to the DARA Solids Storage Unit at the DARA Liquid Storage and Treatment Unit. This Gamewell box is connected to the existing plant Gamewell Fire Alarm System and Plant Monitoring System. A telephone is available in the operator's trailer south of the DARA Liquid Storage and Treatment Unit, and two-way radios are also used to communicate with the PED office, if emergency assistance is needed. Eyewash/safety shower stations are available on the unloading pad at DARA Liquid Storage and Treatment Unit.

The DARA Solids Storage Unit provides storage for contaminated sediments and excavation wastes generated during closure of the Oil Retention Ponds. These sediments are contaminated with PCBs and volatile organic compounds. They will be stored in the unit until they can be scheduled for final treatment or disposal.

\section{Interim Reactive Waste Treatment Area (IRWTA) .}

The IRWTA is located west of the main plant area on Bear Creek Road, and served by an auxiliary fire alarm pull box near the trailers at the closed Sanitary Landfill I. Two-way radios are used to provide communication with the PED office, if emergency assistance is needed. Portable eyewash systems are used during operation. In addition, the $\mathrm{Y}-12$ Fire Department staff is at the unit during the treatment process to assist, if needed. 
This interim unit was designed for the treatment of sodium potassium ( $\mathrm{NaK}$ ) generated during maintenance activities at the Y-12 Plant. The unit currently operates in accordance with an open burning permit. The IRWTA is used approximately once per year dependent upon the generation of $\mathrm{NaK}$ wastes. The Fire Department staff are present through the duration of the burn to ensure safe treatment of the $\mathrm{NaK}$, which is water reactive. The Contingency Plan will also be implemented if an emergency arises. The NaK has a mineral oil layer which takes approximately seven hours to burn. The $\mathrm{NaK}$ itself will burn away in approximately 45 minutes. All wastes and equipment are removed from the treatment area when the burn is completed.

\section{Building 9201-4, Container Storage Area}

Building 9201-4 is located on First Street. Gamewell boxes are located within Building 9201-4 and connected to the existing plant Gamewell Fire Alarm System and the Plant Monitoring System. Two-way radios are used, and a telephone is available on the first floor in the southwest corner of the building for communication with the PED office, if emergency assistance is needed.

This unit is located within the exclusion area of the Y-12 Plant and is used to store mercurycontaminated solids such as soil or insulation in containers. Building 9201-4 provides container storage for 55-gallon drums of hazardous and mixed waste resulting from decontamination and decommissioning activities.

\section{Building 9212 Container Storage Area}

The Building 9212 Container Storage Area is located in Building 9212. Telephones are available in nearby supervisors' offices. Eyewash/safety showers are available at each location. Two-way radios are also used to communicate with the PED office, if emergency assistance is needed. Gamewell boxes are located throughout Building 9212. These Gamewell boxes are connected to the existing plant Gamewell Fire Alarm System and Plant Monitoring System.

This area is used to store organic solutions and residues awaiting recovery of enriched uranium. The solutions and residues are mixed wastes.

\section{Building 9206 Container Storage Area}

The Building 9206 Container Storage Area is located in Buildings 9206 and 9720-17. For areas located in Building 9206, Gamewell boxes are located near Rooms 24 and 30. Eyewash and safety shower stations are also located in these rooms. For the area located in Building 9720-17, a Gamewell box and a telephone are located in the corridor outside the area. A telephone is available in Room 18 of Building 9206. Two-way radios are also available in these buildings for communication with the PED office, if emergency assistance is needed. Gamewell boxes are connected to the existing plant Gamewell Fire Alarm System and Plant Monitoring System. 
Building 9206 is the other building at the Y-12 Plant used to store organic solutions and residues awaiting recovery of enriched uranium. The solutions and residues are mixed wastes.

\section{Uranium Treatment Unit}

The Uranium Treatment Unit is located near Building 9767-2. Eyewash/safety shower stations are available at this unit, and the nearest Gamewell box is located 75 feet north of the area on the East Dock between Doors 4 and 5. This Gamewell box is connected to the existing plant Gamewell Fire Alarm System and Plant Monitoring System. Two-way radios are used and a phone is available nearby in Building 9767-2 to communicate with the PED office, if emergency assistance is needed.

The Uranium Treatment Unit is located on the east side of Building 9206, outside and adjacent to the loading dock. The unit consists of two, 300-gallon polytanks located within a diked drum storage area that stores up to eighteen, 55-gallon drums. This unit treats organic solutions which are mixed wastes.

\section{RCRA and PCB Container Storage Area, Building $9720-58$}

Building $9720-58$ is located on Old Bear Creek Road. Two Gamewell boxes are provided at the east and west sides of Building 9720-58 and connected to the existing plant Gamewell Fire Alarm System and the Plant Monitoring System. Telephones and two-way radios are also used by personnel to provide communication with the PED office, if emergency assistance is needed. A portable eyewash system is provided in the operation trailer adjacent to the unit. A safety shower/eyewash system is also provided at Unit OD-9 that is located directly west of Building 9720-58.

Building 9720-58 is utilized as a storage and staging area for PCB-contaminated equipment (e.g., transformer, capacitors, and electrical switch gear). The area is also used to store RCRA hazardous waste and used as a staging area for other waste materials awaiting off-site shipment. Waste is consolidated at this area until waste analysis and appropriate disposal arrangements can be initiated. 


\section{Building 9720-12 Classified Container Storage Area}

The Building 9720-12 Classified Container Storage Area is located on West Second Street. The nearest Gamewell box is located in the northwest corner of Building 9720-12. This Gamewell box is connected to the existing plant Gamewell Fire Alarm System and Plant Monitoring System. Portable eyewash and safety shower stations are used. Two-way radios are used to communicate with the PED office if emergency assistance is needed.

Building 9720-12 is a storage unit for hazardous, nonhazardous, and mixed waste. Waste is stored at this building until waste analysis and appropriate recycling techniques can be arranged. 



\section{APPENDIX B}

\section{EMERGENCY and SPILL RESPONSE EQUIPMENT}

\section{Spill Response Trailer Equipment and Supplies}

The Y-12 Plant Spill Response Trailer, maintained by the Fire Department, is located in the plant and contains supplies and equipment for the response team. The following is an indication of the typical contents of that trailer:

Respirators

Rubber Boots

Rain Suits

Paper Suits

Rubber Gloves

Acid-type Gloves

Acid Suits

Respirator Cartridges (Combination)

Flagging

Stakes

Face Shields (complete)

Chemical Splash Goggles

Flashlights

Extra Batteries

Caution Lights (flashing)

Shovels, Round Point

Shovels, Square Point

Sledgehammer

Broom (street type)

Tape

Hose Clamps

Plastic Bags (small)

Full Face Respirator

Absorbent Diapers

Sample Bottles

Rope

Twine

Rubber Aprons

Ax
Ladder (10 ft.)

Reflector Vest (orange)

Water (for pump)

Demineralized Water

Pipe Wrench

Pliers

Pliers, Needle Nose

Adjustable Wrench

Vise Grips

Screwdriver (flat tip)

Screwdriver (Phillips head)

Channel Lock Pliers

Teflon Tape

3" to 2" Pipe Coupling, Stainless

Plastic Bags (large)

3" Threaded Coupling

Fire Extinguisher 
Building 9720-41

Additional supplies and equipment is located in Building 9720-41. Typical supplies and equipment are listed below:

Pigs

Gas and Air Driven Pumps

Oil Skimmer Booms

Sandbags

Empty Drums (including overpack drums)

Absorbent Diapers

Hoses

Gloves

Ear Plugs

Safety Glasses

Generators

Lighting Systems

\section{Building 9753}

Additional supplies and equipment is located in Building 9753. Typical supplies and equipment are listed below:

Leather Gloves

Rubber Gloves

Flashlights

Flashlight Batteries

Chemical Splash Goggles

Shovels

Picks

Boots

Sand Bags

Plastic, 20' x 100' Rolls

Plastic Bags

Barrels

Road Cones

Flagging Strips

Rope

Absorbent Diapers

Paper Suits

Rain Suits 
Fire-Fighting and Medical Response Vehicles:

The Y-12 Plant Fire Department typically operates the following fire-fighting and medical response vehicles:

Fire Pumper No. 1

Fire Pumper No. 2

Fire Pumper Backup

Cardox Fire Fighting Truck

Emergency Response Truck

Fire Chief's Truck

Service Van

Routine Transportation Van

Fire Fighting Equipment Truck

Routine Transportation Truck

Fire Captains' Truck

Medical and Routine Transportation Truck

Ambulance No. 1

Ambulance Backup

Ambulance Backup

Emergency Spill Response Truck 
APPENDIX C

EXAMPLES OF EMERGENCY MUTUAL AID COORDINATION AGREEMENTS

Page C-1 


\section{Department of Energy}

Field Office, Oak Ridge

P.O. Box 2001

Oak Ridge, Tennessee 3783i-

January 11, 1994

Mr. Frank K. Martin, Director

Energy Systems Protective Services

Martin Marietta Energy Systems, Inc.

P. O. Box 2009

Oak Ridge, TN 37831-8107

Dear Frank,

MUTUAL AID AGREEMENT FOR EMERGENCY AMBULANCE SERVICE, EAST TENNESSEE REGION

Enclosed is a copy of the subject agreement which has been executed by the Oak Ridge Operations Office (ORO) and the Tennessee Department of Health. This is a progressive agreement which enhances the emergency medical response system throughout the sixteen county East Tennessee region.

The ORO Emergency Operations Center (EOC) will serve as the point of contact for the Regional Response Communications Center (RRCC) for requests to ORO for support from Martin Marietta Energy Systems under the agreement. Based upon conversations with your staff, the Y-12 Plant Shift Superintendent (PSS) will serve as the point of contact for the ORO EOC for requests for the Energy Systems Oak Ridge facilities to provide support under the agreement. Likewise, the Y-12 PSS will coordinate any requests from Energy Systems for support for the Oalk Ridge facilities and forward such requests to the RRCC through the ORO EOC.

This letter constitutes advance authorization for offsite response of Energy Systems emergency medical resources under the provisions of this Mutual Aid Agreement when such requests are received by the Y-12 PSS from the ORO EOC.

Also enclosed is a copy of the East Tennessee Medical Regional Understanding for the Activation of Mutual Aid. This document should be used as guidance in your preparation of implementing procedures for this agreement. Please ensure that your procedures provide for periodic updates to the ORO EOC concerning any activities being conducted offsite and notification to the ORO EOC of termination of such activities. 
As with other mutual aid agreements, the decision to offer units for offsite response should be predicated upon consideration of facilities' conditions at the time and the maintenance of an appropriate reduced level of response capability for the Oak Ridge facilities.

Questions may be addressed to Bobby Davis of my staff at 6-9725. Your support is appreciated.

Sincerely,

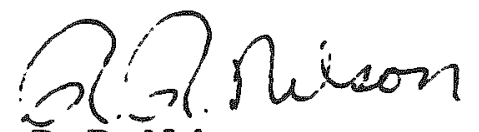

R. R. Nelson

Acting Assistant Manager

for Defense Programs

\section{Enclosures}

cc: w/encls.

Ron Hultgren, ER-10

John Rothrock, SE-33

Bill Phelps, DP-82

Karen Edwards, AD-440

Tom Tison, EW-96

Bob Spence, DP-81 


\section{MUTUAL ADO AGREEMENT FOR EMERGENCY AMBULANCE SERVICE \\ EAST TENNESSEE REGION}

THIS AGREEMENT entered into and executed this 1st day of October 1993 between the U.S. Department of Energy (DOE). Oak Ridge Operations Office and Licensed Ambulance Service (County or Private) to provide for the joint operations of Emergency Ambulance Service within the geographical boundaries of the 16 county East Tennessee Region.

WHEREAS, pursuant to the provisions of Tennessee Code Annotated (T.C.A.) 7.61. 102. county is authorized to provide ambulance services as a public service; and,

WHEREAS, T.C.A. 7-6I-104(b), authorizes cooperation between cities and counties for the provision of ambulance services and T.C.A. 12-9-101, et. seo. same being the "Interlocal Cooperation Act provides legal authority for the parties to cooperate on the basis of mutual advantage to provide Emergency Ambulance Services in facilities for the needs and development of local communities; and further the Atomic Energy Act, 42 United Siates Code (U.S.C.) 2011 et seg. the Department of Energy Organization Act, 42 U.S.C. 7101 et seg. and the Stafford Disaster Relief and Emergency Assistance Act, 42 U.S.C. 5121 et seg. provide further authority for the Dof to enter into this agreement:

WHEREAS, it is necessary and desirable that an agreenent be executed authorizing the interchange of such Emergency Ambulance Service between the parties. 
HOH. THEREFORE, IN CONSIDERATION OF THE MUTUAL PROMISES AND CONDITIONS CONTAINED HEREIN, THE PARTIES AGREE AS FOLLOUS:

\section{Duration of Agreement}

A. This agreement shall be effective as to each party when it has been approved by the governing bodies of the licensed ambulance services and shall continue to be effective for five (5) years from that date or until termination. The agreement may be terminated by any party by giving the other parties 30 days written notice.

B. Termination of this agreement may be effected by the governing body of each party adopted with the same formality as at the parties original approval of this agreement: provided that no such termination shall be effective until the expiration of 30 days after termination by either governing body. All the rights, remedies, and obigations of the parties will remain in effect until such 30 days expire.

C. The DOE will not be required to provide 30 days written notice if DOE determines that the department's mission or other national security matters make termination necessary.

\section{Services Provided}

Each party agrees that its emergency services and resources will be available to answer emergency calls within the jurisdiction of the other 
in order to provide adequate and traty Emergency Ambulance Service in accordance with the polfefes and procedures as provided in Paragraph 4: provided, however, that no party to this agreement shall be required to make resources available or render service to any other party when by providing such services an unreasonable danger to lives or property of that party's residence or employees would result. The responsible persons designated by the governing bodies of each ambulance service or the service director for either party shall determine what resources and services can be reasonably provided this agreement. Neither party will be required to obtain additional resources of any nature to carry out this agreement.

3. Emergencies

Upon request by any of the parties and upon notification of an emergency occurring within the jurisdiction serviced by either party, the county or service may enter into the geographical boundaries of the other party to offer and render such Emergency Ambulance Service as either party deems appropriate under the circumstances. The county or service may provide such equipment and personnel of their ambulance service as it deems appropriate under the particular circumstances. An emergency occurrence as defined by this agreement consists of a situation bevond the nomal and routine services being provided on a requiar basis by the responsible agency so that local resources are overwhelmed. This agreement in no situation releases either party from having a::ailabie resources in order to fulfill day-to-day obligations being incurred by that party routinely. 
When party responds to an emergency within the geographical boundarles of one of the other parties as contemplated by this agreenent, the responding party may, but is not obligated to, charge a fee for services it deems necessary. Such fee would not be charged to the party requesting assistance but to the individual(s) transported by the responding party.

\section{Policies and Procedures}

The governing bodies of each licensed ambulance service do by this agreement authorize the county executive, mayor, ambulance service director, or their designee to establish the necessary policies and procedures to be followed in requesting and responding to requests for assistance provided such are authorized by applicable state or federal law, the ambulance service agreement if applicable and the mutual aid agreement.

\section{Authority for Responding Personnel}

A. In all occasions where emergency ambulance personnel travel from their geographical boundaries to that of another the jurisdiction, authority, rights, privilęges, and immunities which they have in their jurisdiction shali extend to and be available to them in the geographical area they respond to.

8. The senior officer of the Emergency Ambuiance Service, or his or her designee within his jurisdiction on the scene of an energency shall be 
in comand of the emergency as to strategy, tactics, and overall direction of the operation. Additional resources from outside the Iast Tennessee Region: 1.e.. ambulance, air ambulances, hospital bed count, ete., will be coordinated by the Regional EMS Director.

All orders or directions regarding the operations of the party and the jurisdiction of the other party shall be relayed to the senior officer in command of the party acting outside its jurisdiction provided, however, that neither this agreement or any agreements executed contemporaneous herewith shall be construed as creating a duty on the part of any party to stay at the scene of the emergency except as may be decided by the senior officer of that party.

C. Either party may depart the scene of the emergency at any time the senior officer of that party deems it appropriate at which time the senior officer of the other party shall be in complete command.

D. The Regional Resource Coordination Center will be used to coordinate communications with responding parties.

6. Lability

At any time. a party requests the aid of another party, the requesting party shall not be liable for damages to the equipment or personnel of the responding party. Neither shall the requesting party, its officers, agents, or employees be liable for any damages caused by negligence of the 
personnel of the responding party while en route to or returning from the scenc of an energency.

7. Waiver of Claims

Each party hereby waives any and all claims against the other party for any costs, losses, damages, personal injuries, or wrongful death arising out of the operations of this agreement or for any loss or damage to their respective employees and property which may occur in the performance or nonperformance of this agreement. Each party will be responsible for furnishing its own equipment and personnel and shall be responsibie for all expenses necessary for their operation.

8. Limits of Liability

This agreement is construed by the parties to be function of the local governments to the extent that liability arises out of the performance of this agreement. Ambulance services under government control will avail themseives of the protection of the Tennessee Governmental Tort Liability Act as found in T.C.A. 19-20-101, et sed.

\section{Entire Agreement}

This agreement contains the entire agreement between the parties. Should a court of confident jurisdiction deciare any provision of this agreement to be null and void or unenforceable, such provision shall be stricken but 
such determination shall not affect the validity of the remaining portion: of this agreement.

U. S. DEPARTMENT OF ENERGY
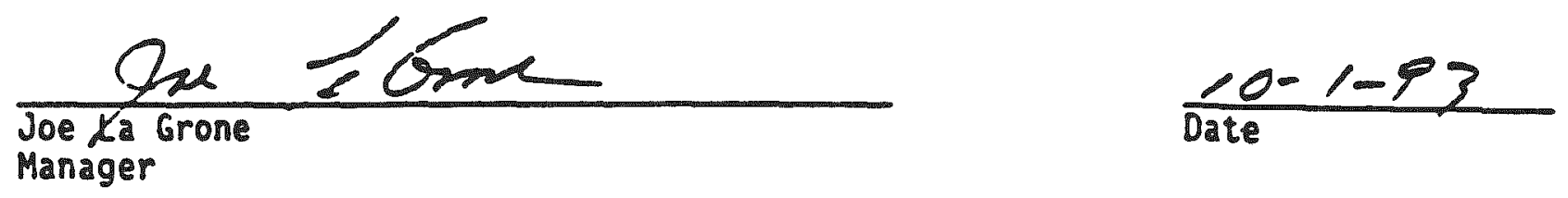

TENNESSEE DEPARTMENT OF HEALTH

EAST TENNESSEE REGION
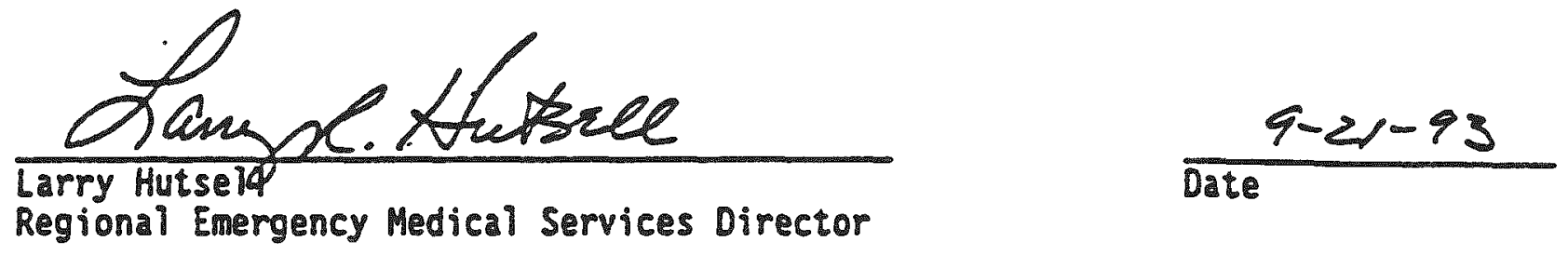

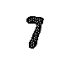

Page C-10 


\title{
LETIERS OR AGREEMENT MEHORNDUNS OF UNDERSTANDING
}

\author{
A local 1a enforcenent mutul agrement bas been ade brween the \\ ciry of Oan rldge and Doe. This liter can be accoscod chrough the \\ Ciry of Oak aldge.
}

ME

\author{
T0: ZaDorable Mar \\ Haber of CIT coumell

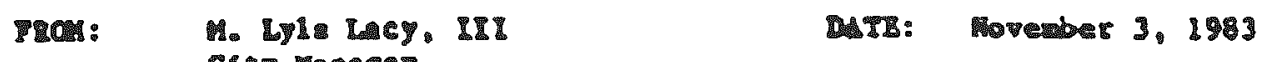

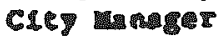

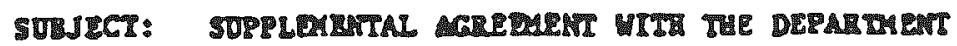

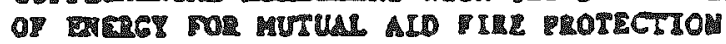

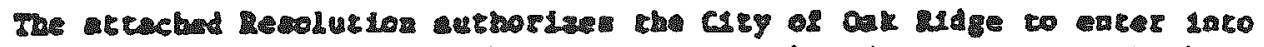

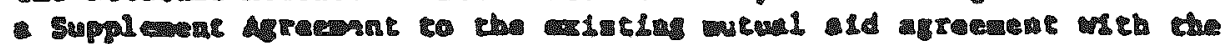

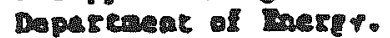

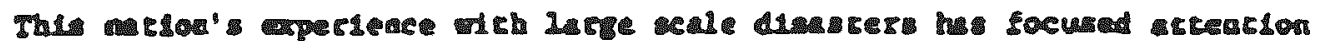

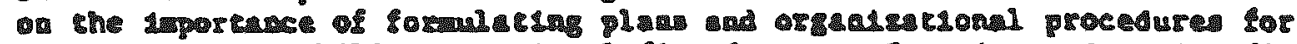

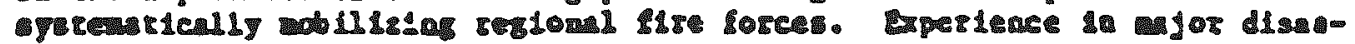

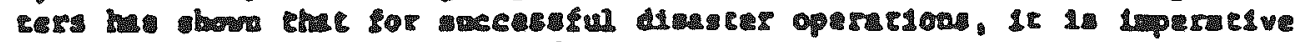

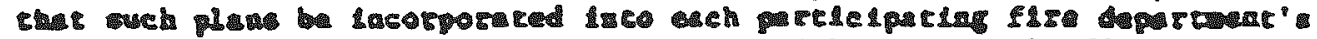

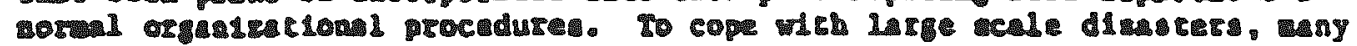

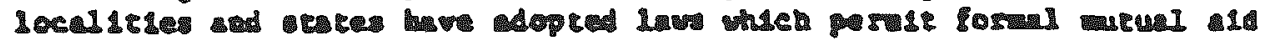

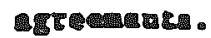

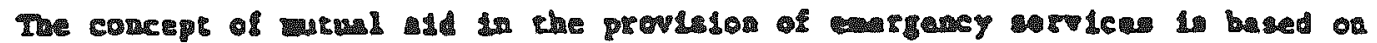

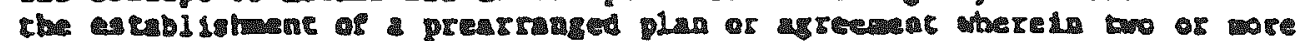

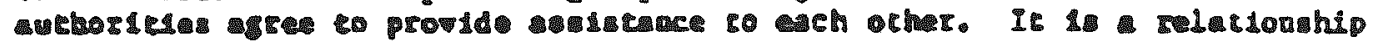

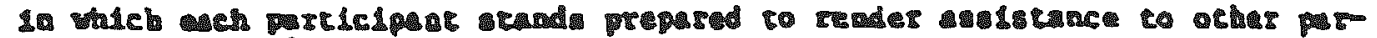

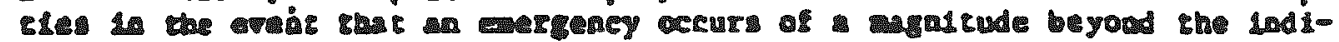
- Lun

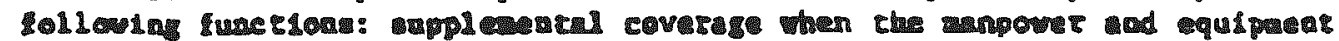

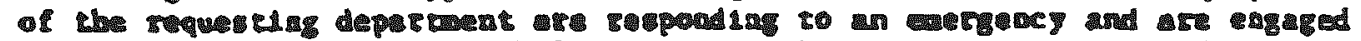

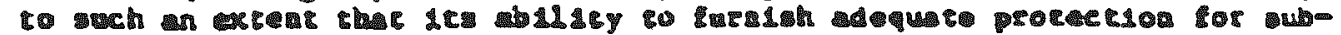

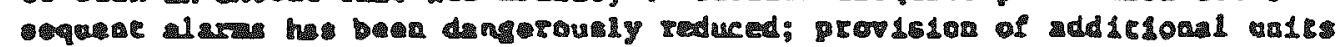

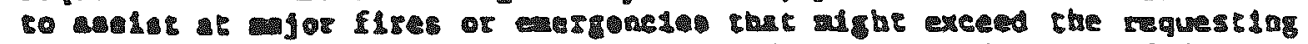

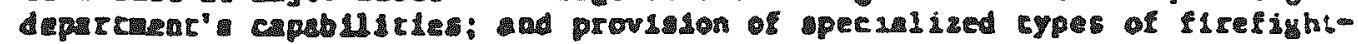

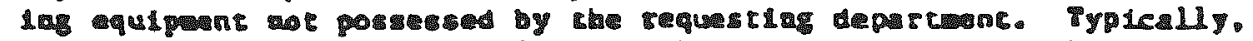

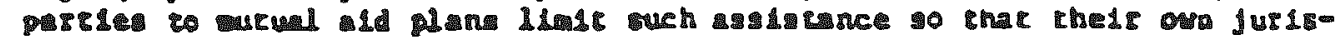

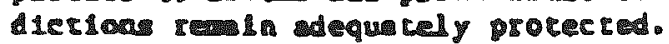

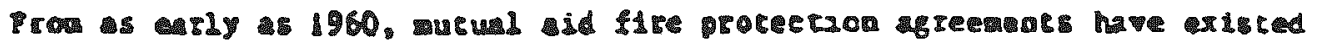

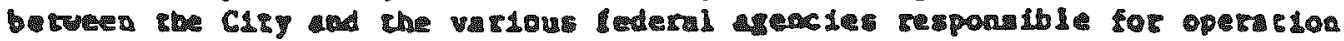

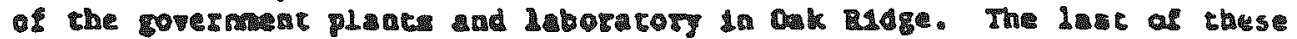

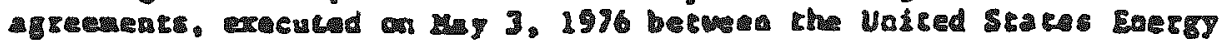

Deat Interi Plan. $3 / 87$

$$
\text { IV-P-1 }
$$




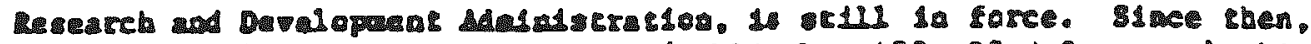

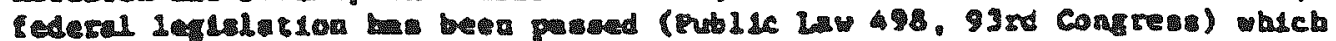

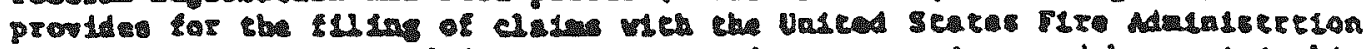

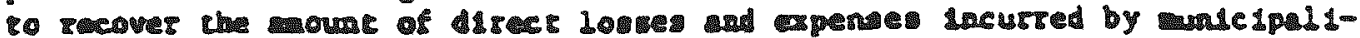

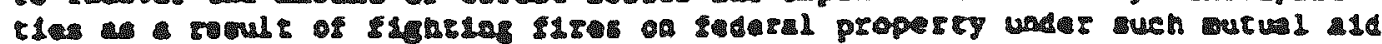

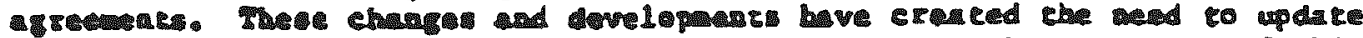

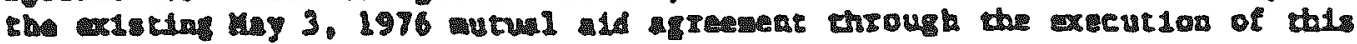
-

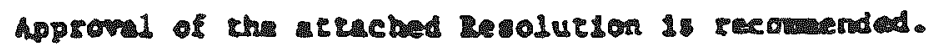

\section{LyI L6Y. III}

If

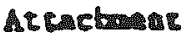




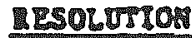

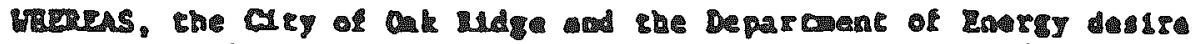

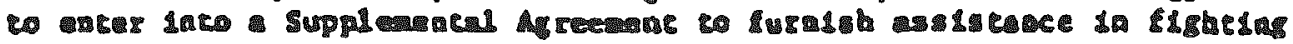
15. 15. Ind

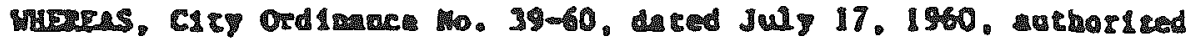

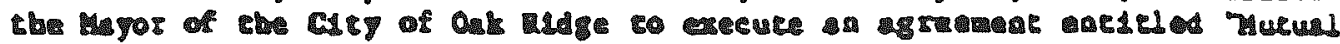

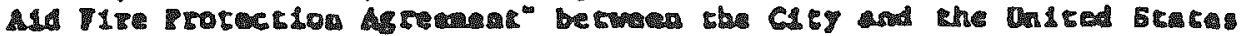

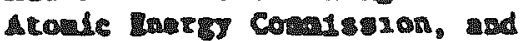

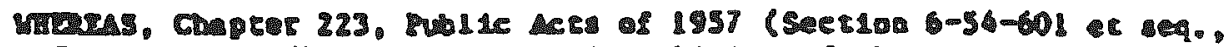

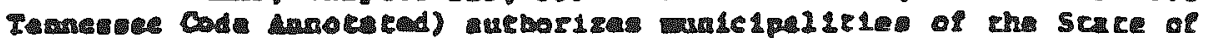
Bema

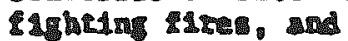

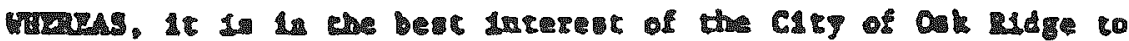
1. 16.

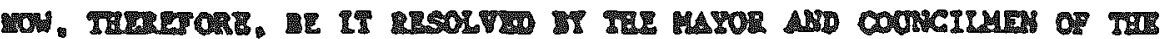

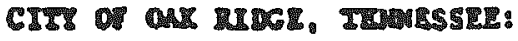

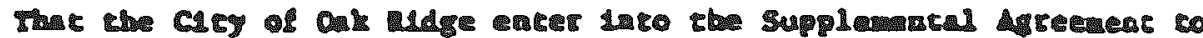

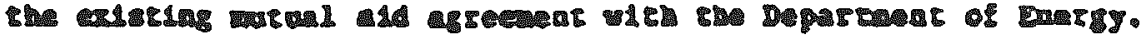

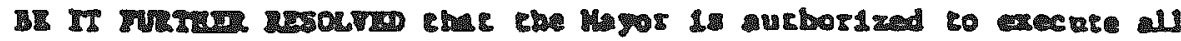

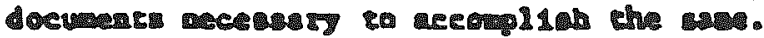

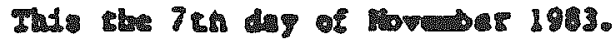

AMPOE AS To TOR

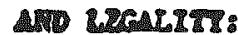

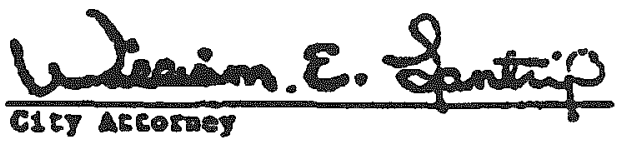

218

C18Y CIE

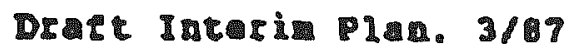

IV -3 


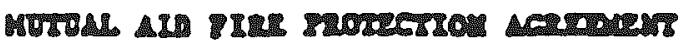

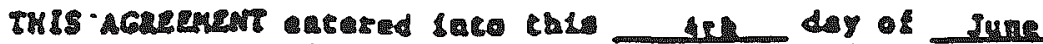

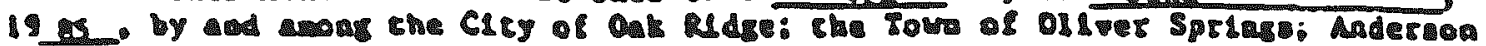

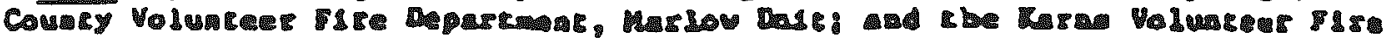

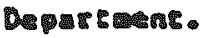

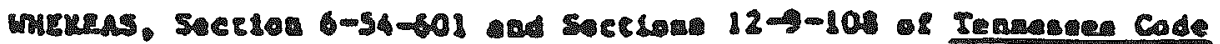

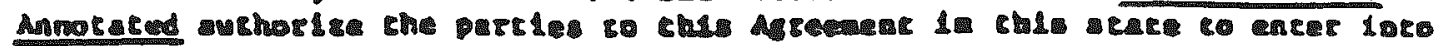

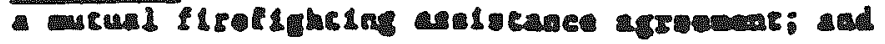

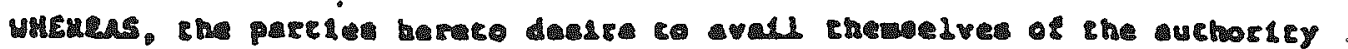

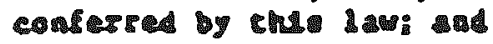

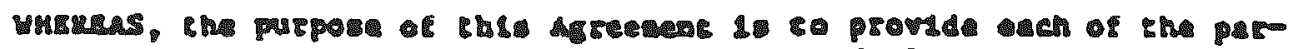

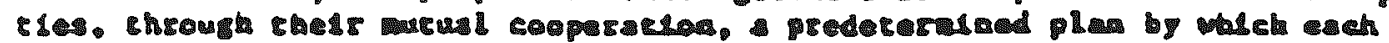

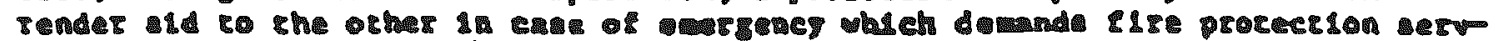

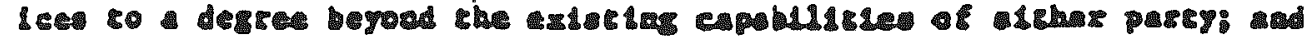

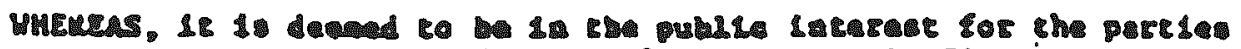

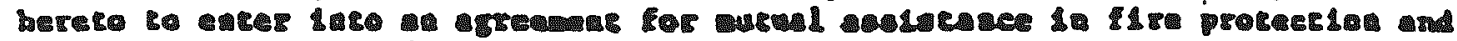

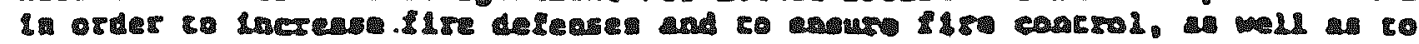

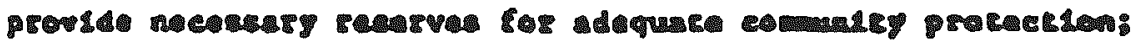

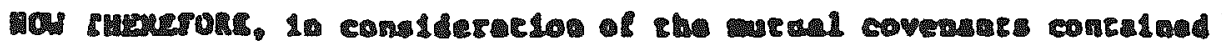

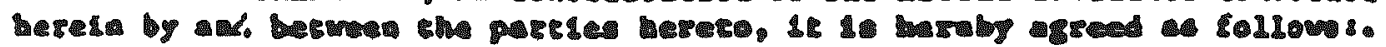

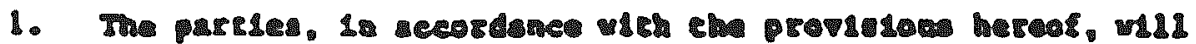
r

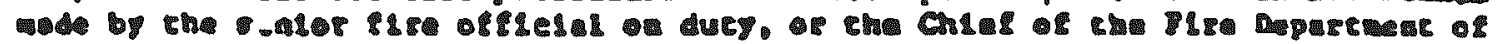

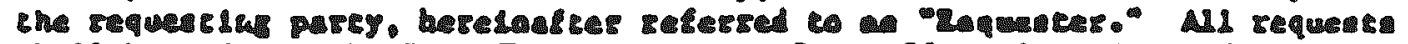

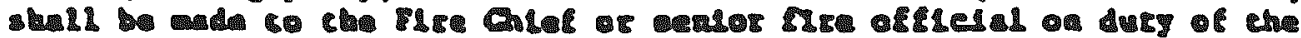

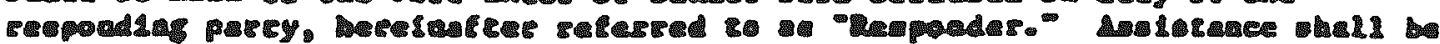

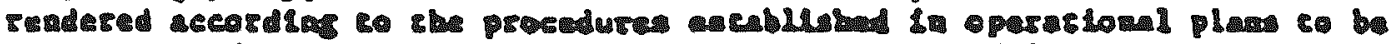

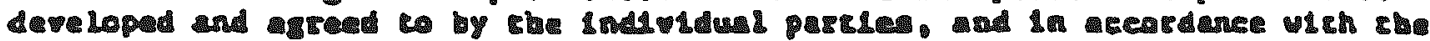
provis do rover.

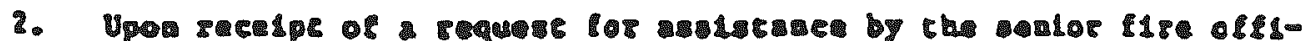

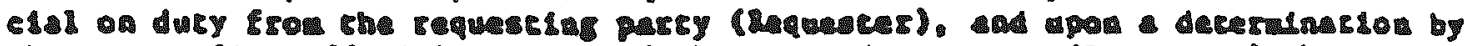

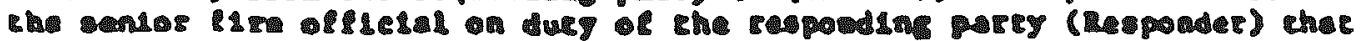

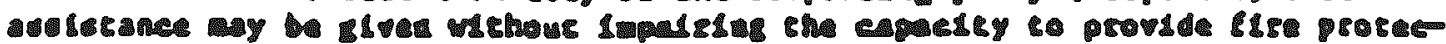

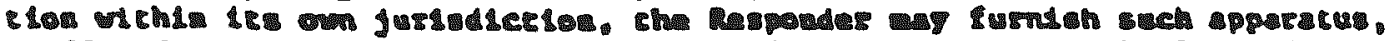

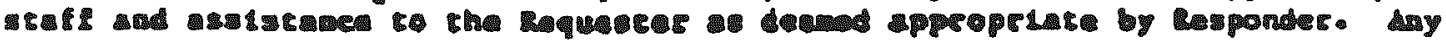

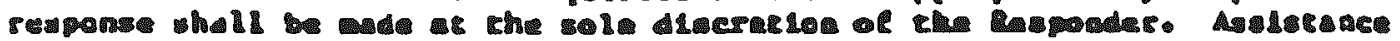

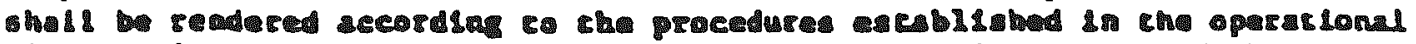

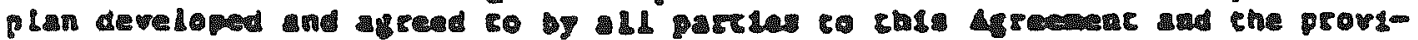
sons merer.

Dratr larerin : 18a. 3/R

TV-1 


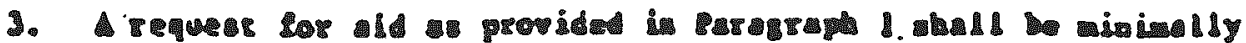

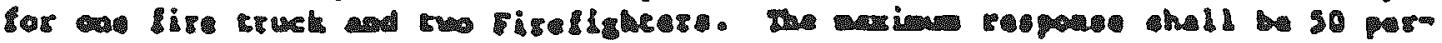

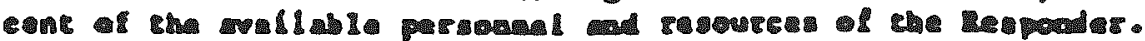

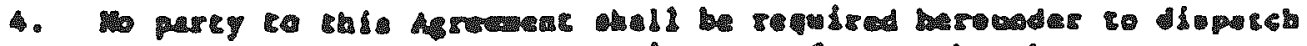

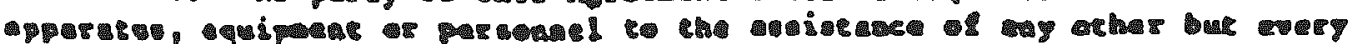

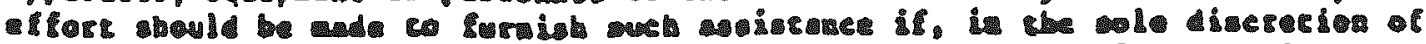

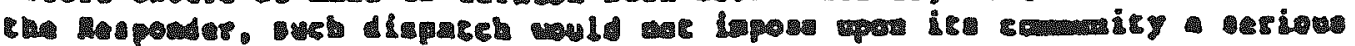

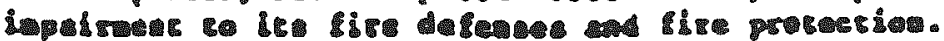

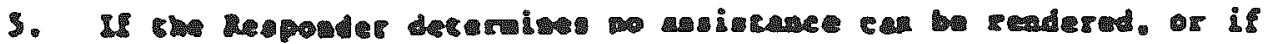

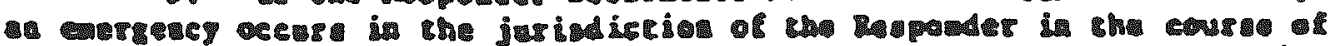
-

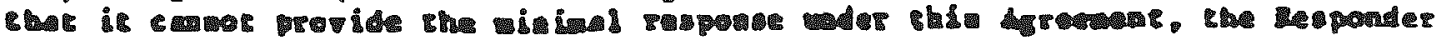

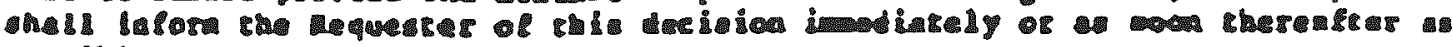
parise

In I ver

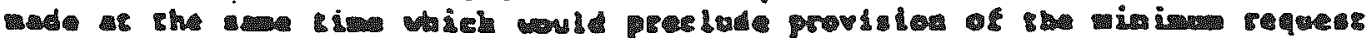

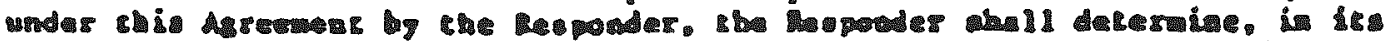

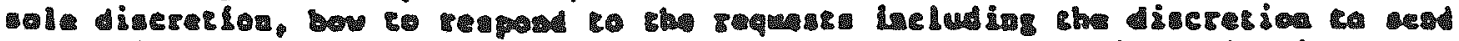

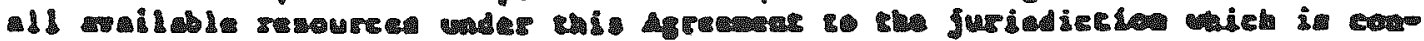

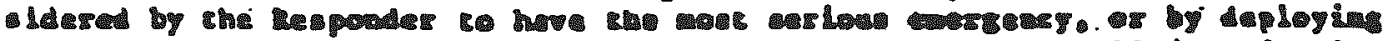

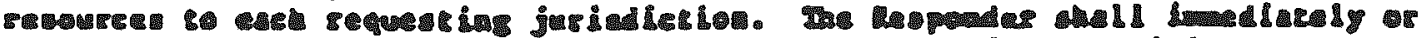

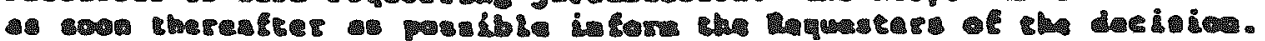

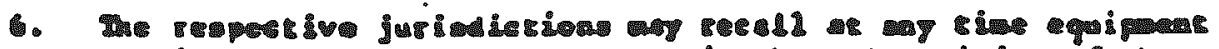

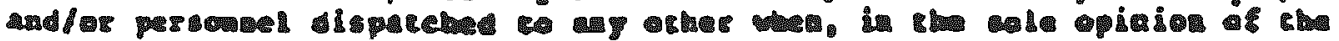

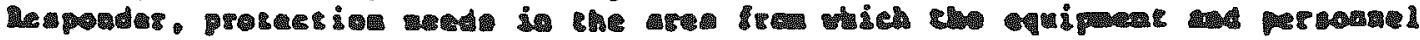

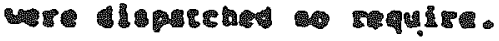

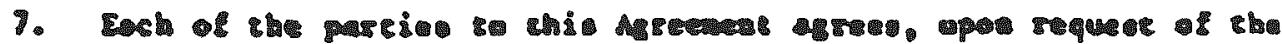

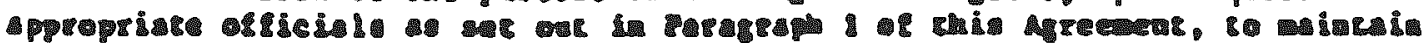

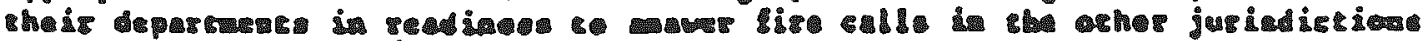

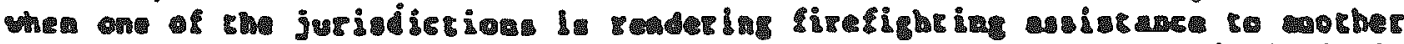

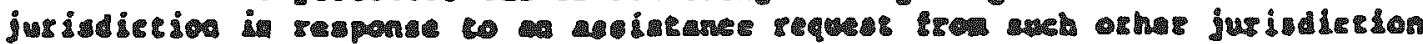

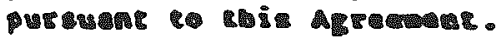

2. The Copoder

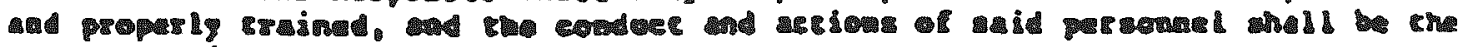
I. 28:

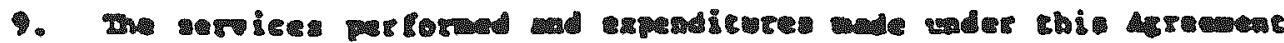

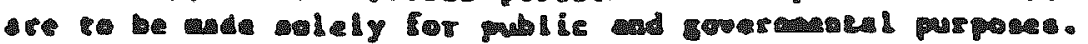

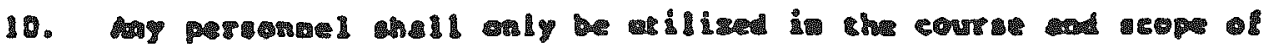

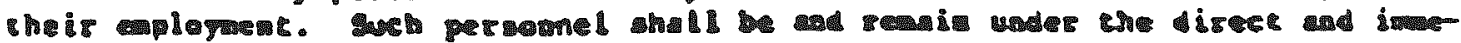

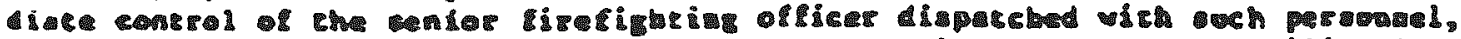

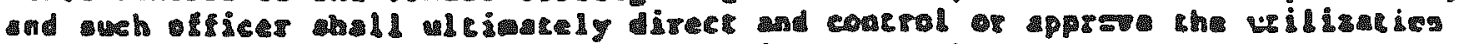

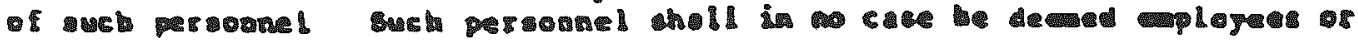

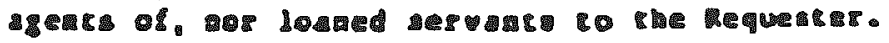

Drate Incesin PIan. $3 / 67$ 


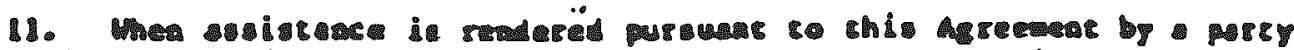

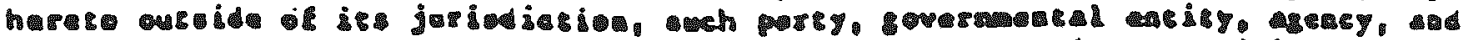

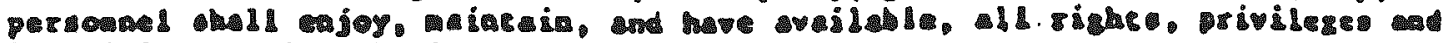

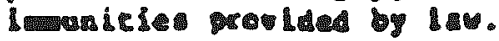

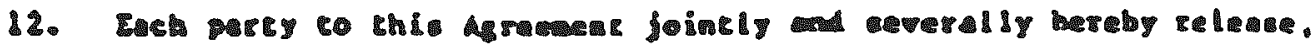

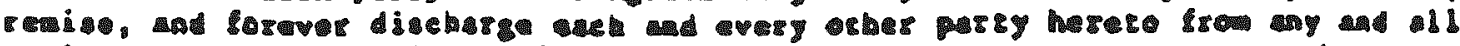

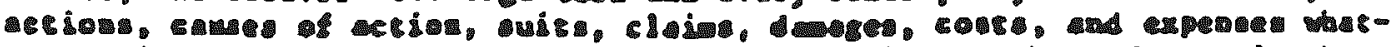

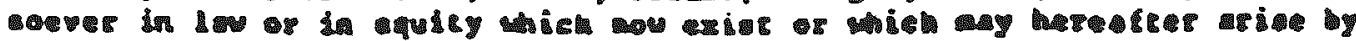

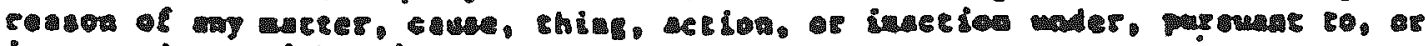

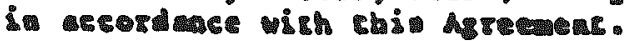

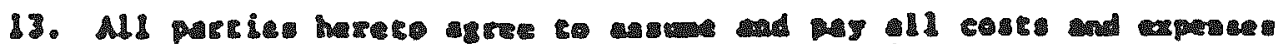

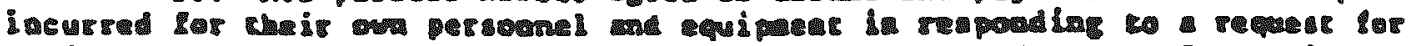

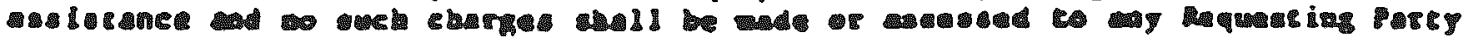

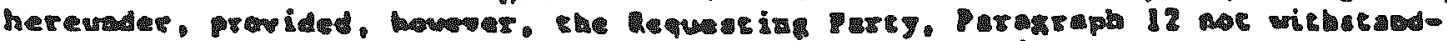

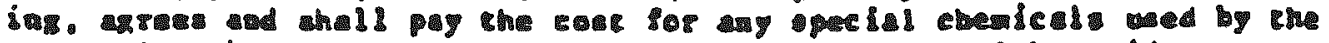

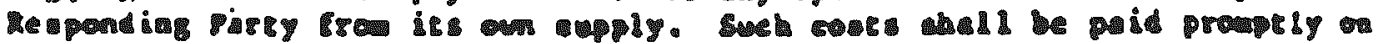

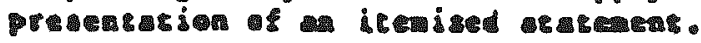

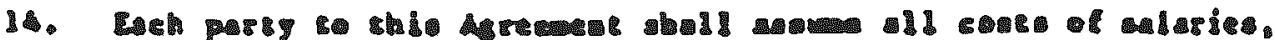

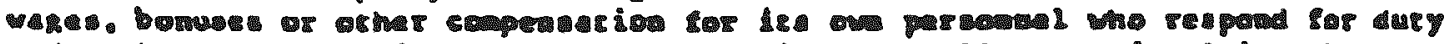

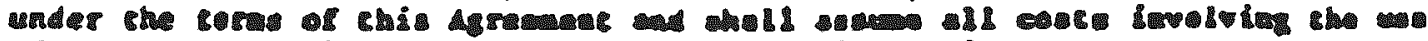

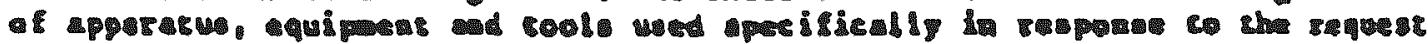

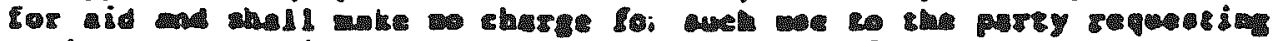

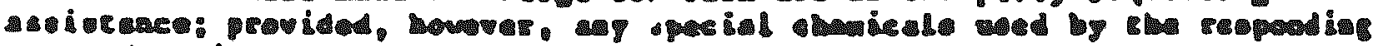

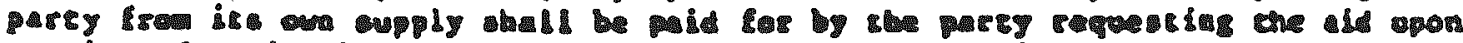

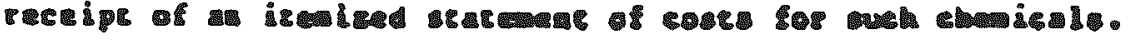

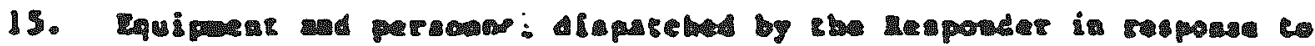

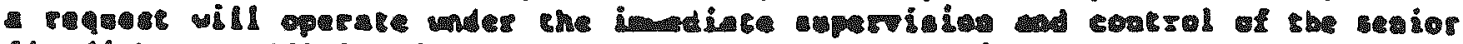

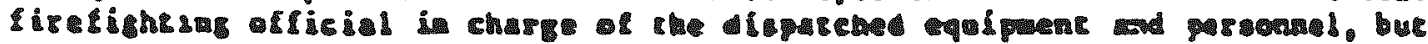

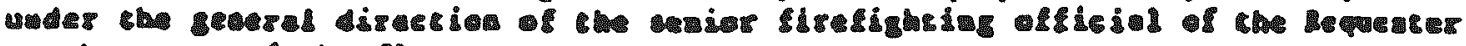

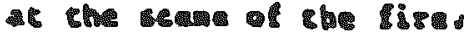

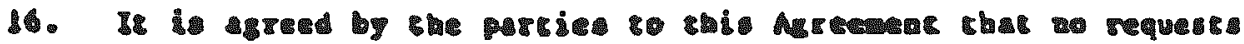

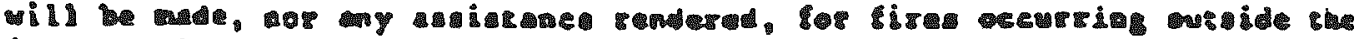

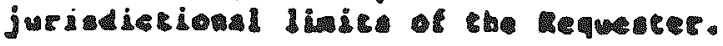

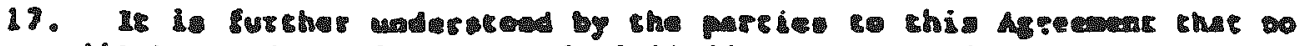

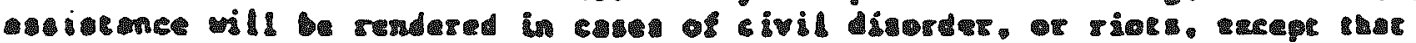

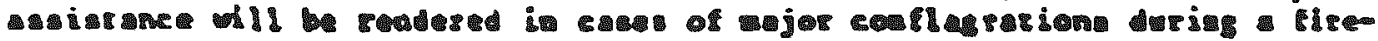

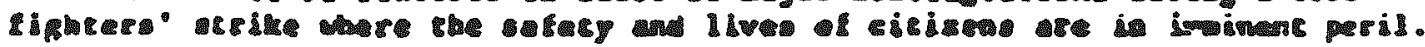

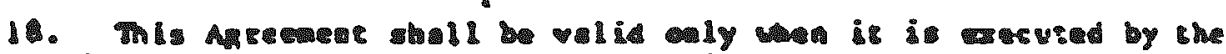

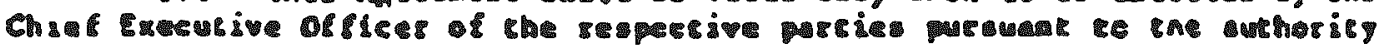

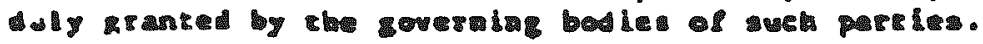




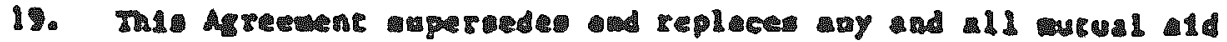

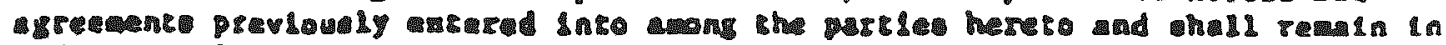

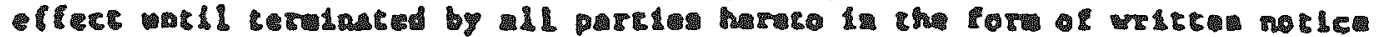

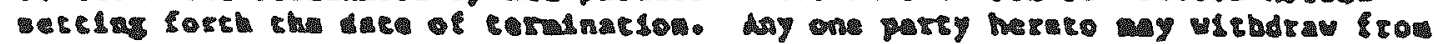

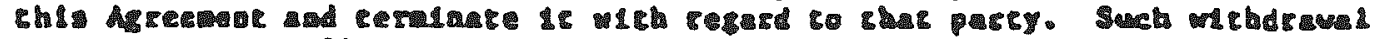

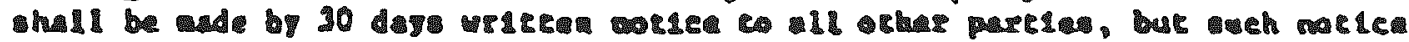

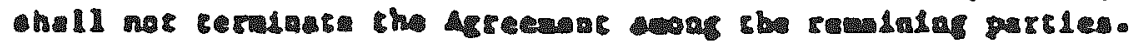

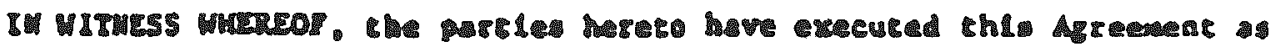

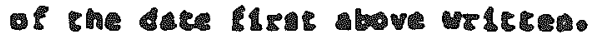

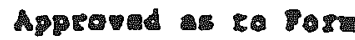

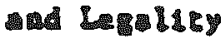

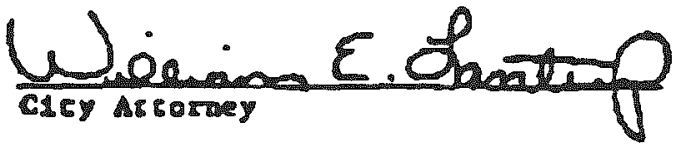

\section{CITY OP OAC RIOCR}

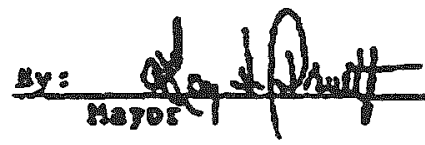
$\because \cdot$ Arrese: CHE CIE:

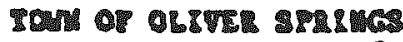

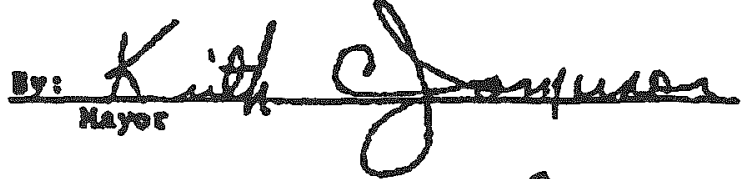

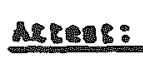

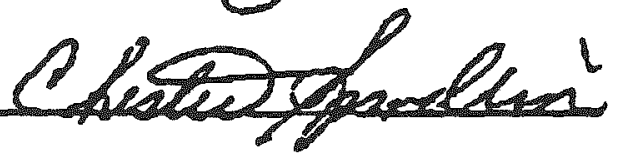

4MoR

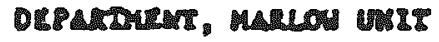

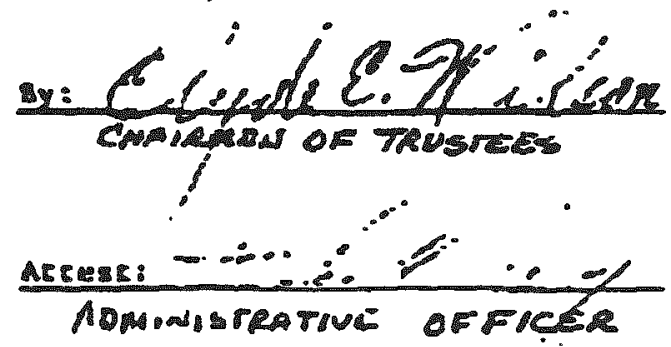

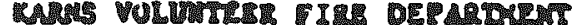

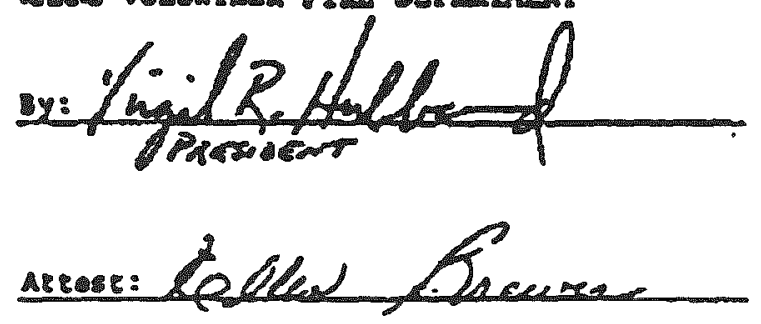

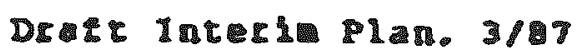




\section{During an}

\section{Emergency Evacuation,}

Go to Assembly Station 10

- $9401-5$ (อ $9720-18$

(2) 9722

(3) $9720-14$

(4) $9720-51$
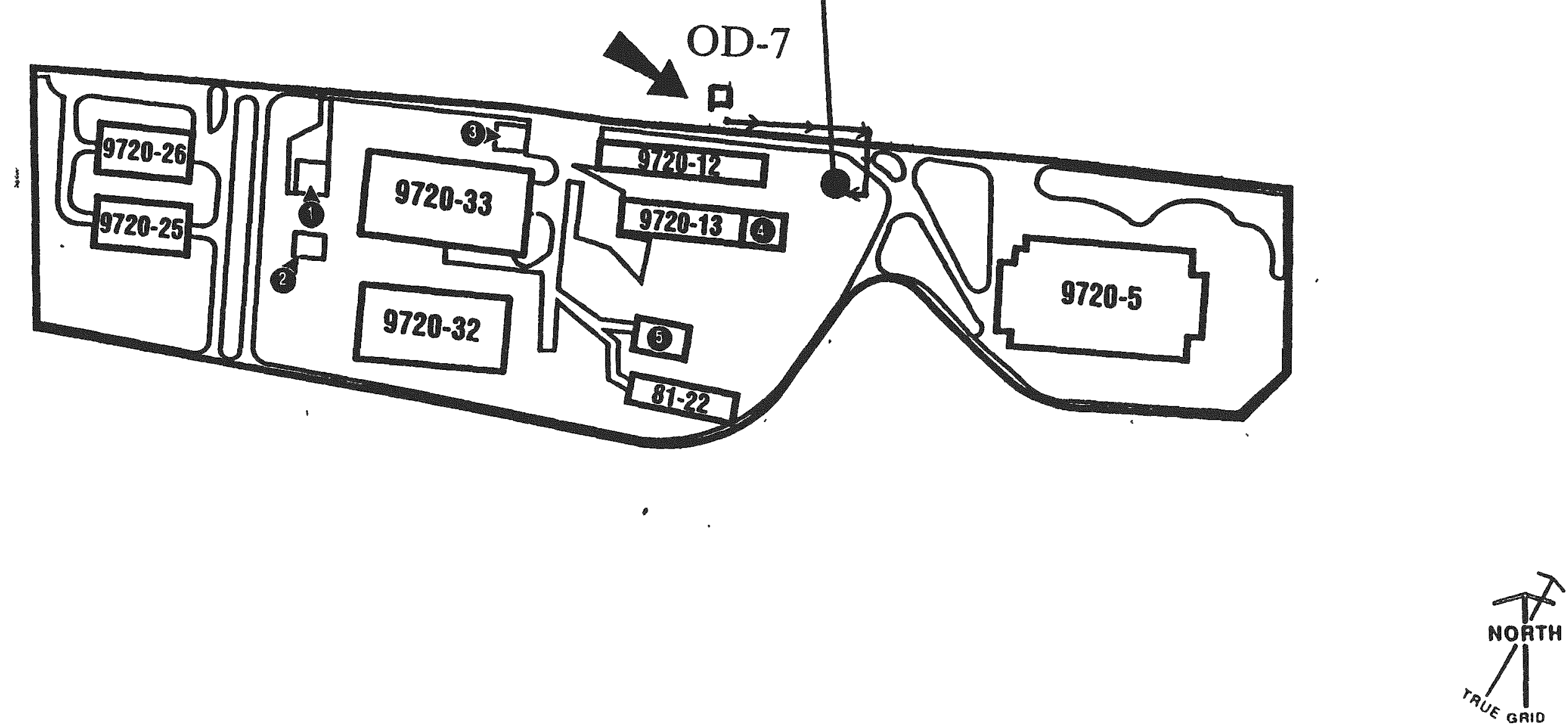

Figure 5

OD-7

EVACUATION ROUTE 


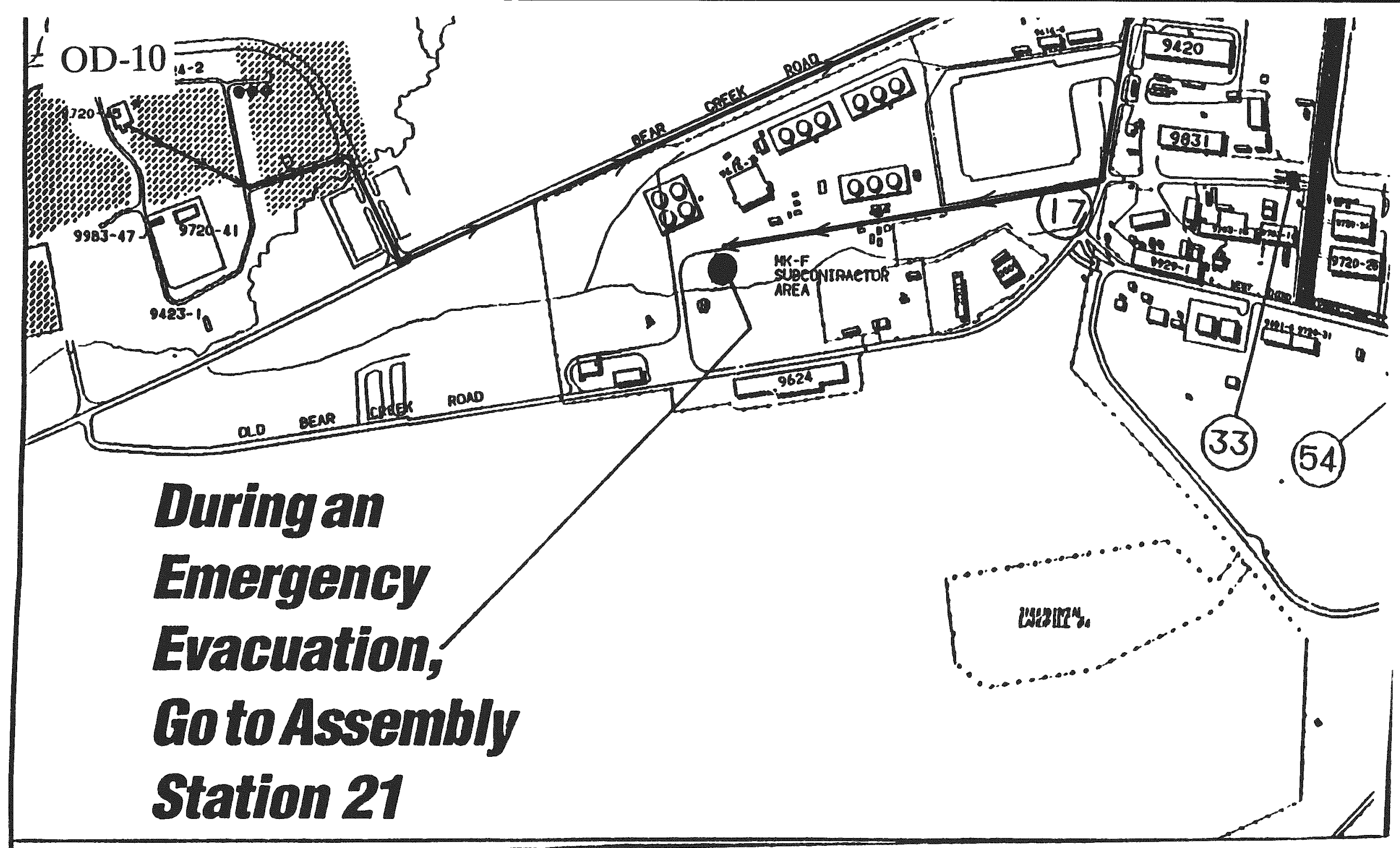

Figure 7

OD-10

EVACUATION ROUTE 


\section{OAK RIDGE Y-12 PLANT \\ WASTE UNIT \\ IDENTIFICATION KEY}

APPLICATION EPA

LINE PROCESS COOE DESCRIPIION

$1 \ldots \ldots . . . . . .$. CYOANIDE TREATMENT UNIT

SO!

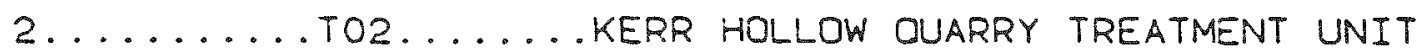

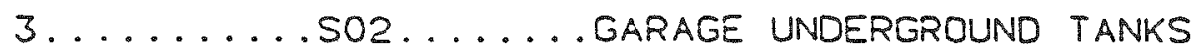

$4 \ldots \ldots . \ldots . . . . .680 \ldots$ WALK-IN PITS

$5 \ldots \ldots . . . . . . .501 \ldots$ INTERIM DRUM YARD

$6 \ldots . . . . . .501 \ldots . . .$. BUILDING $9720-9$ STORAGE UNIT

$7 \ldots . . . .$. SO $\ldots . .$. RCRA \& MIXED WASTE STORAGE \&

STAGING BUILDING 9720-31

$8 \ldots \ldots . . . . . .$. BUILDING $9811-1$ RCRA

TANK STORAGE UNIT

9.........SO1.......BUILDING $9811-1$ RCRA

CONTAINER STORAGE UNIT

$10 \ldots . \ldots$. SO ......WASTE OIL/SOLVENT STORAGE UNIT SOI

$11 \ldots . . . . .5 O 2 \ldots . . .$. LIO. ORGANIC SOLVENT STOR. UNIT SOI

$12 \ldots . \ldots . . . . . . . . .503 \ldots$ EAST CHESTNUT RIDGE WASTE PILE

$13 \ldots . . . .$. SO $1 \ldots . .$. CONTAINERIZED WASTE STORAGE AREA

$14 \ldots \ldots . . . . . .$. SO $1 \ldots$ CLSSIFIED CONTAINER STORAGE UNIT BUILDING $9720-25$

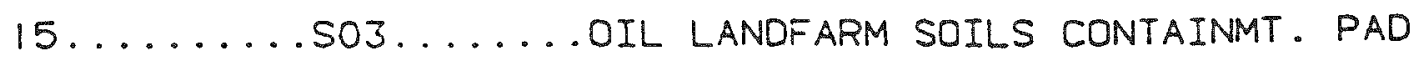

$16 \ldots . . . . . . . .503 \ldots$. ....SPOSAL AREA REMEDIAL ACTION

(DARA) SOLIDS STORAGE UNIT

$17 \ldots \ldots$.......... URANIUM TREATMENT UNIT

SOI

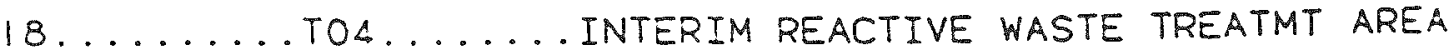

$19 \ldots \ldots . . . . . . .301 \ldots$ BUILDING 9720-12 CLASSIFIED

CONTAINER STORAGE AREA

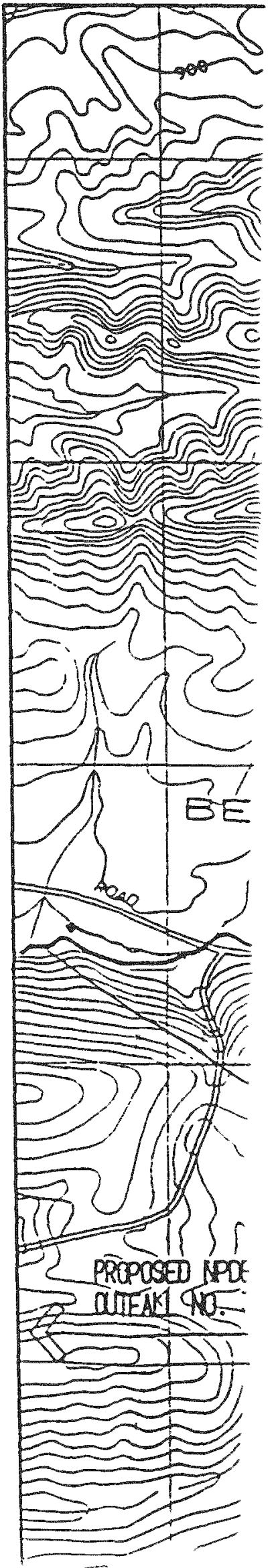




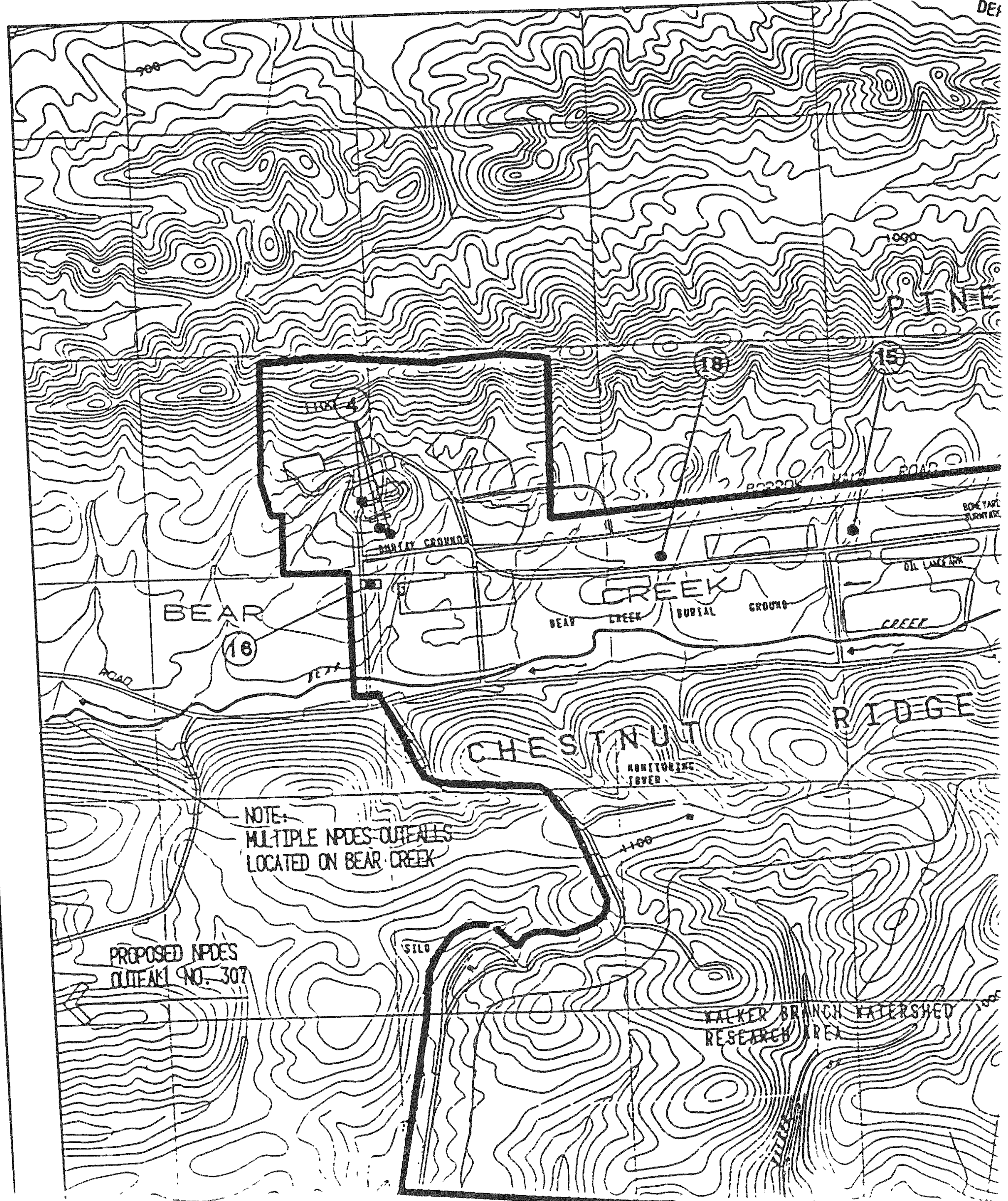




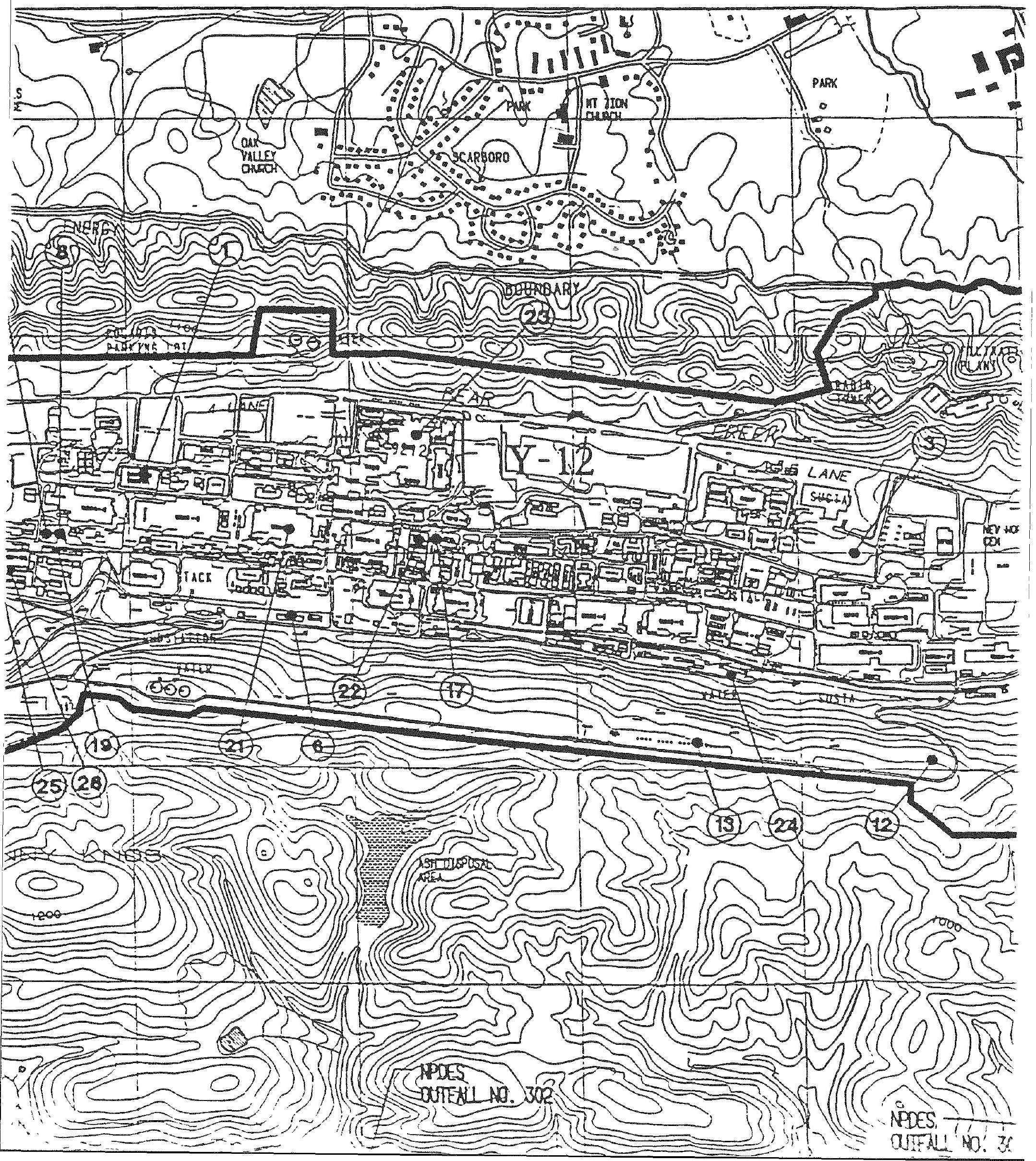




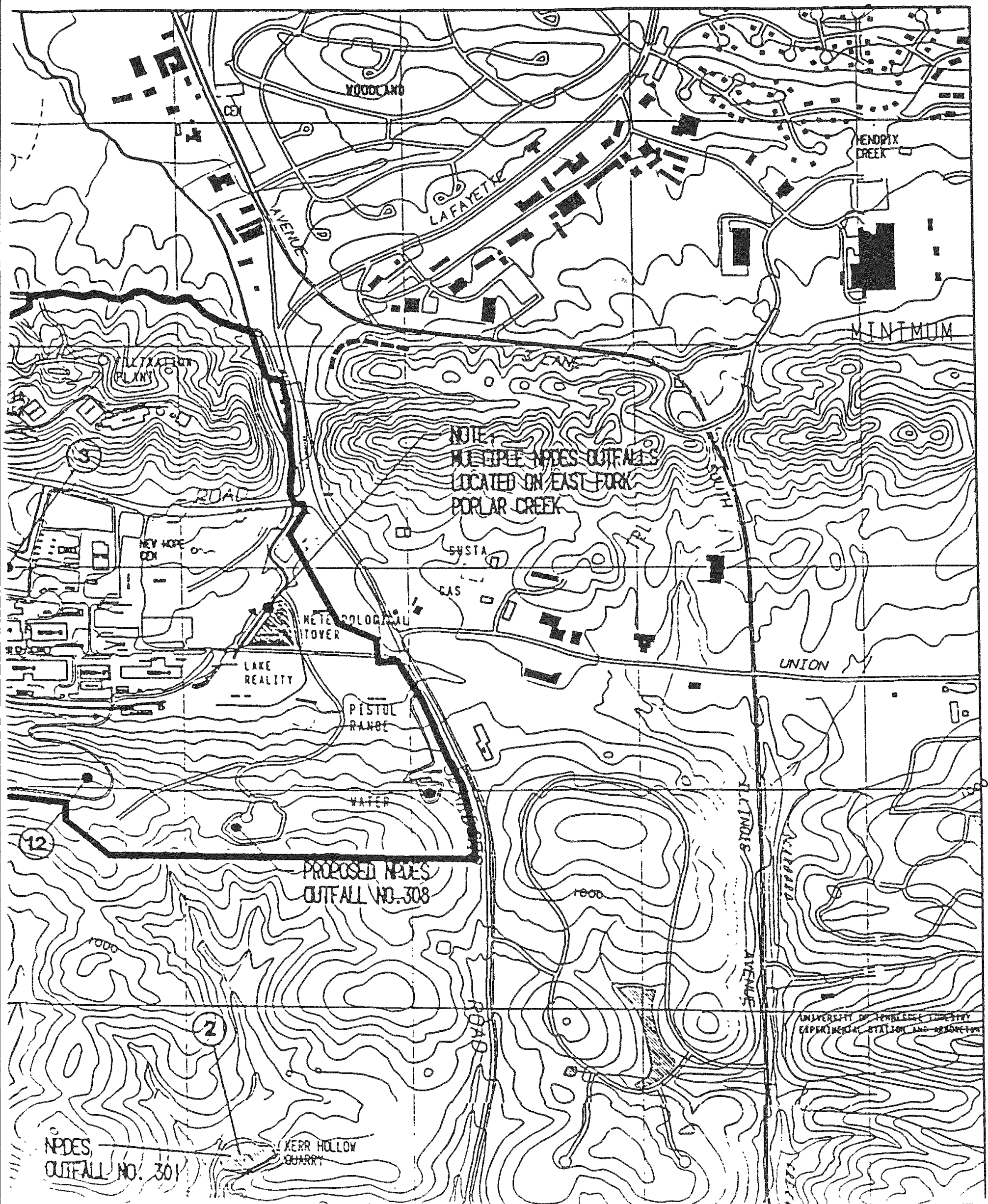


$2 \ldots . \ldots . . . . .$. TO $2 \ldots E R R$ HOLLOW OUARRY TREATMENT UNIT

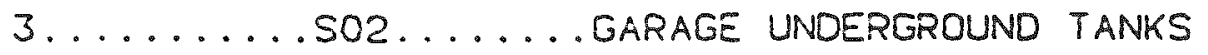

$4 \ldots \ldots$..... . . . . WALK-IN PITS

$5 \ldots \ldots . .$. ........ INTERIER DRUM YARO

$6 \ldots \ldots \ldots . . . . . . . . .$. SUILDING $9720-9$ STORAGE UNIT

$7 \ldots . . . . .501 \ldots . .$. RCRA \& MIXED WASTE STORAGE \& STAGING BUILDING 9720-31

8.........SO2...... BUILDING $9811-1$ RCRA

TANK STORAGE UNIT

$9 \ldots . . . . .501 \ldots . .$. BUILDING $9811-1$ RCRA

CONTAINER STORAGE UNIT

$10 \ldots . . .$. SO $\ldots . .$. WASTE OIL/SOLVENT STORAGE UNIT

SOI

SO2.......LIO. ORGANIC SOLVENT STOR. UNIT

SOI

EAST CHESTNUT RIDGE WASTE PILE

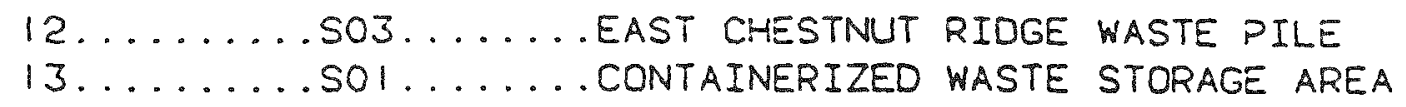

$14 \ldots \ldots . .$. SO $1 \ldots . .$. CLASSIFIEO CONTAINER STORAGE UNIT

BUILDING 9720-25

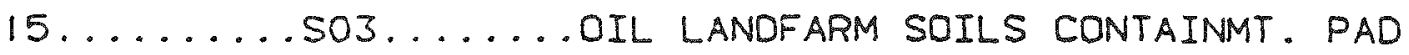

$16 \ldots . \ldots . . . . .503 \ldots$. . . SPOSAL AREA REMEDIAL ACTION

(DARA) SOLIDS STORAGE UNIT

$17 \ldots \ldots . . . . .$. TO URANIUM TREATMENT UNIT

\section{SOI}

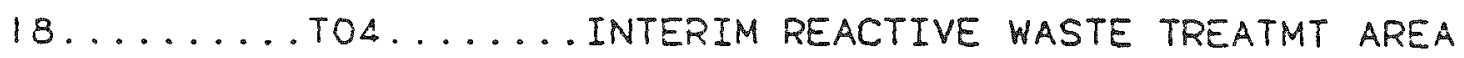

$19 \ldots . . . .$. SO $1 \ldots . .$. BUILDING $9720-12$ CLASSIFIED

CONTAINER STORAGE AREA

$20 \ldots \ldots . . . . .501 \ldots$ RCRA AND PCB CONTAINER

STORAGE AREA. BUILDING 9720-58

$21 \ldots . . .$. SO $1 \ldots . .$. BUILDING $9201-4$ CONTAINER

STORAGE AREA

$22 \ldots . . . . .501 \ldots . . .$. BUILDING 9206 CONTAINER STORAGE AREA

$23 \ldots . . . . .501 \ldots . . . .8$ SUILOING 9212 CONTAINER STORAGE AREA

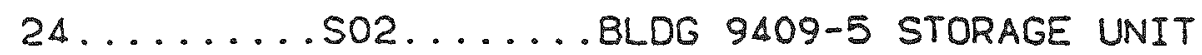

$25 \ldots . . . . .501 \ldots . .$. .... BLDG 9720-32 PRODUCTION WASTE

STORAGE UNIT (FUTURE)

$26 \ldots . . . . .501 \ldots . .$. BLDG 9720-59 CLASSIFIED WASTE

STORAGE UNIT (FUTURE)

$27 \ldots . . . .$. SO $1 \ldots .$. . . OAK RIDGE RESERVATION STORAGE UNITS (FUTURE)

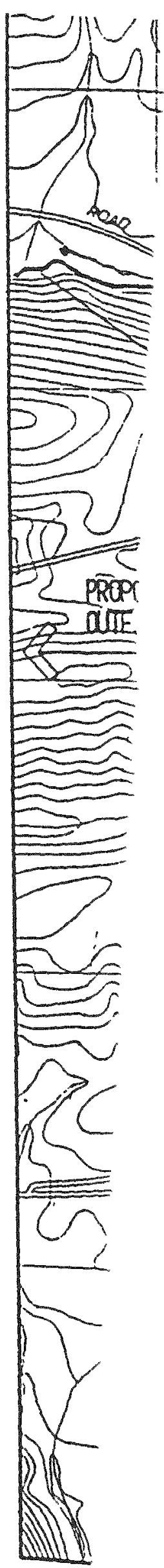

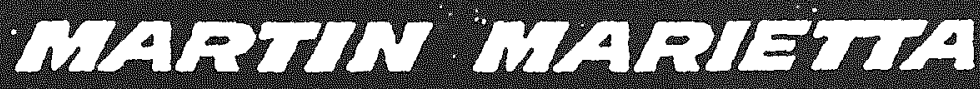

Y-12 PLAMT RCRA MASTE UNIT LOCATIONS

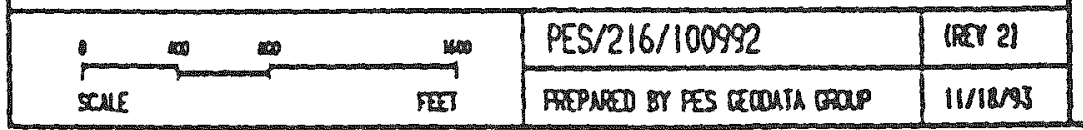

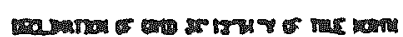
กบ

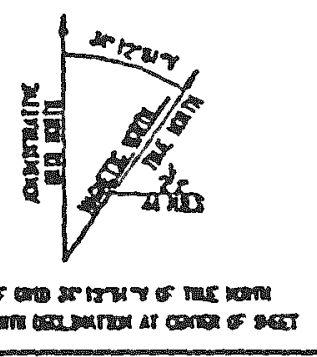




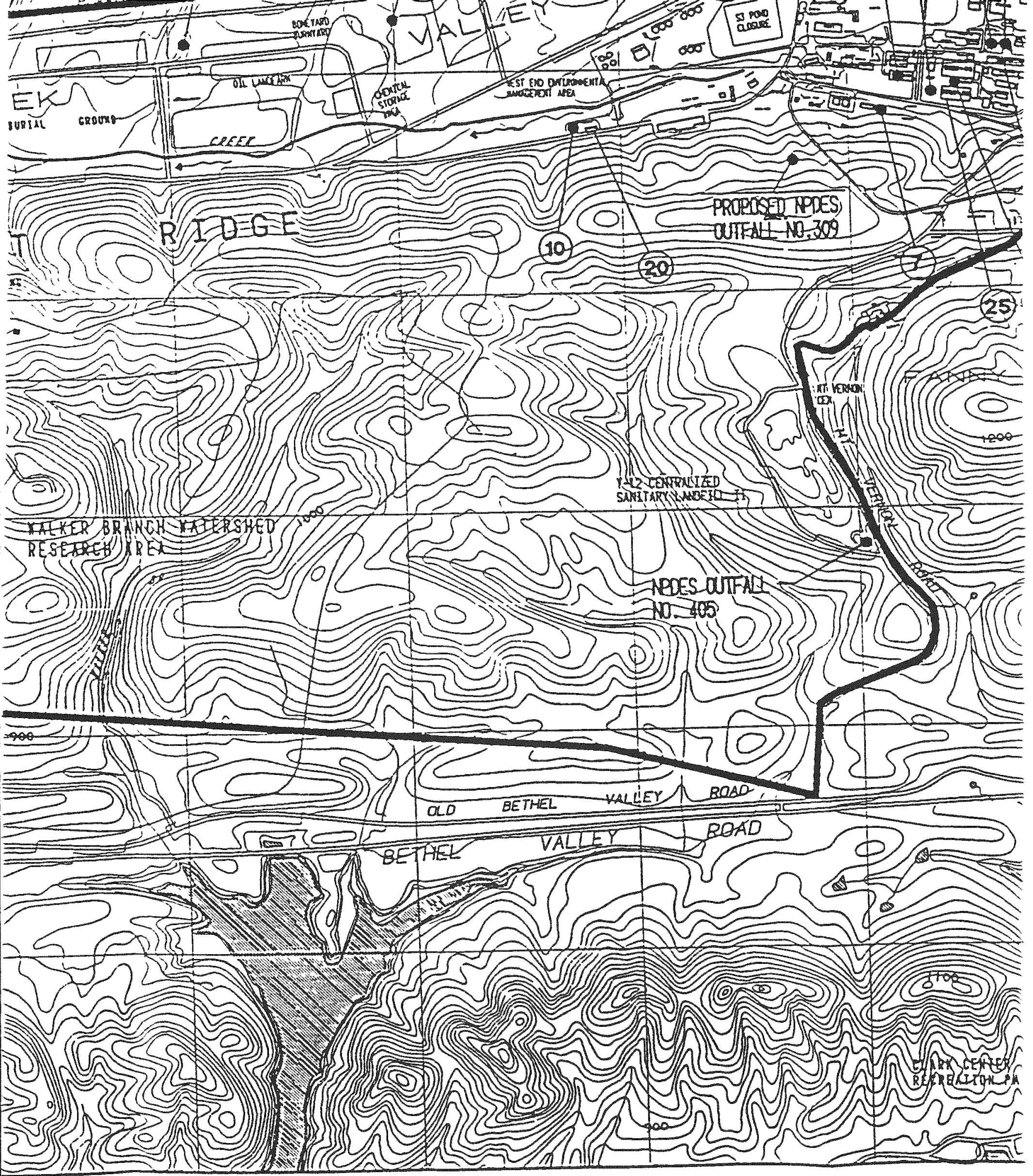




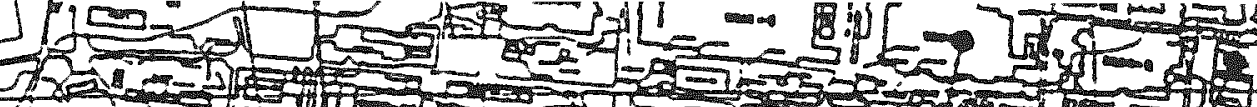
S

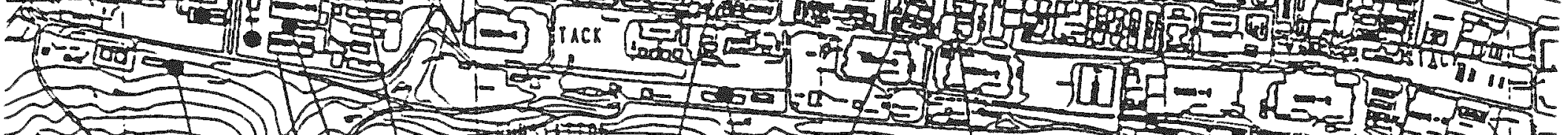

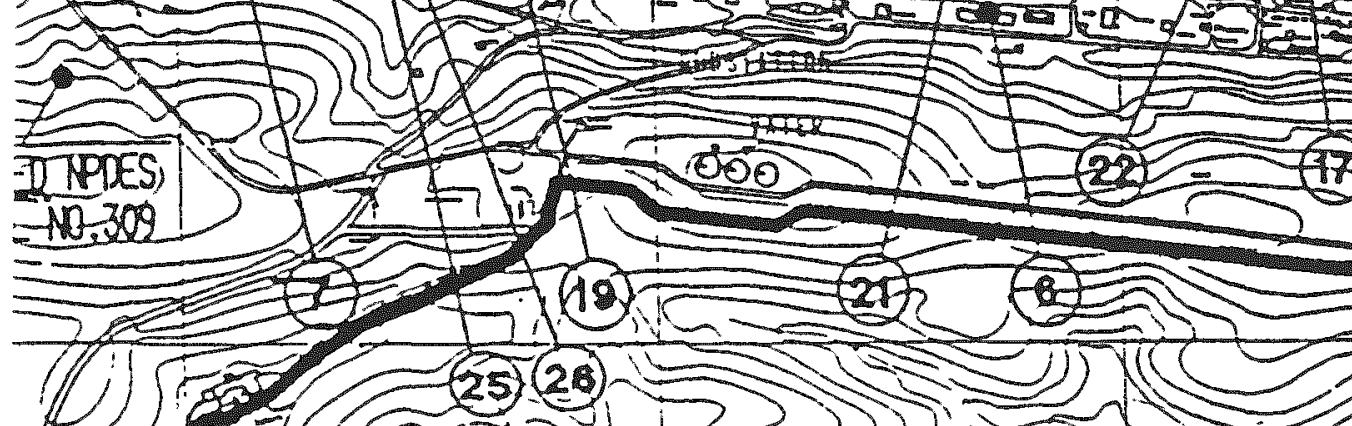
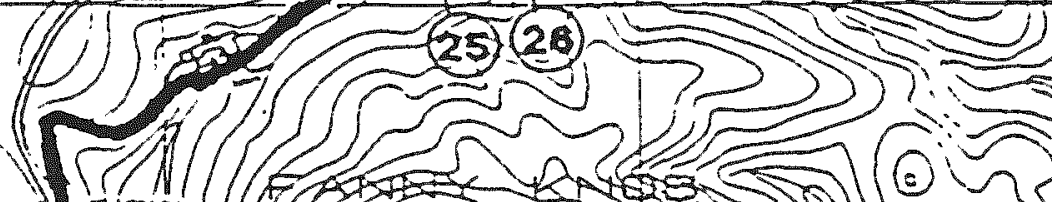

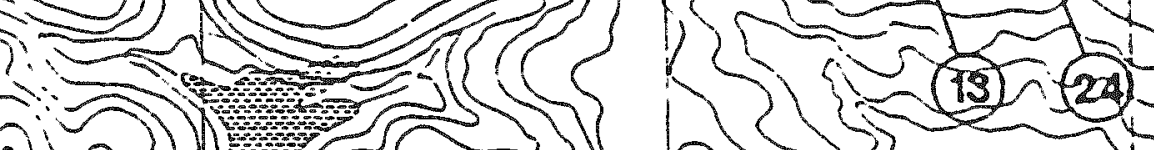
$\left\{\begin{array}{l}2=-5 \\ 2(13)\end{array}\right.$

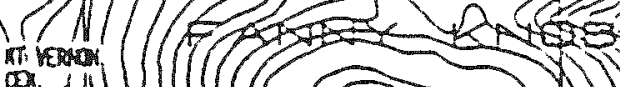

$\infty$

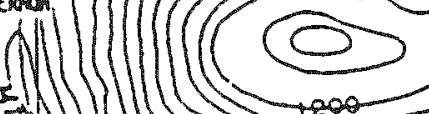

it.

Silh

मी 1202
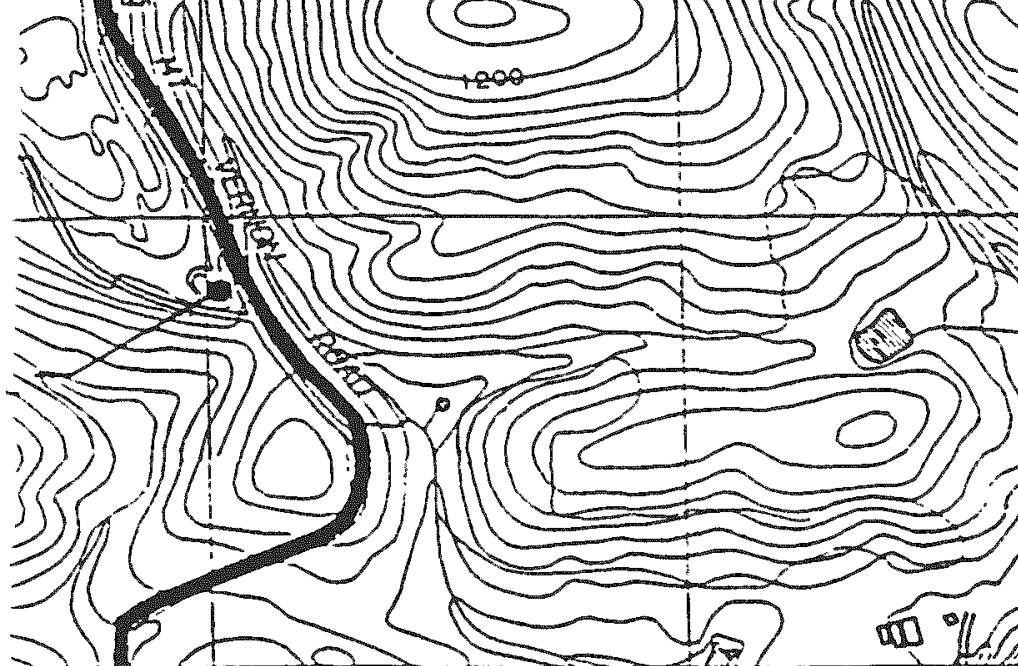

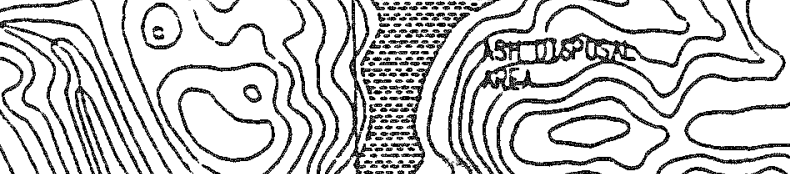

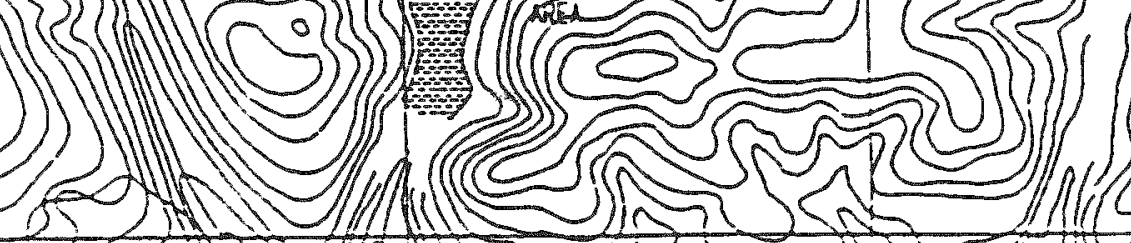

15010 $(\sqrt[3]{2})$

(

an $\%$ कि
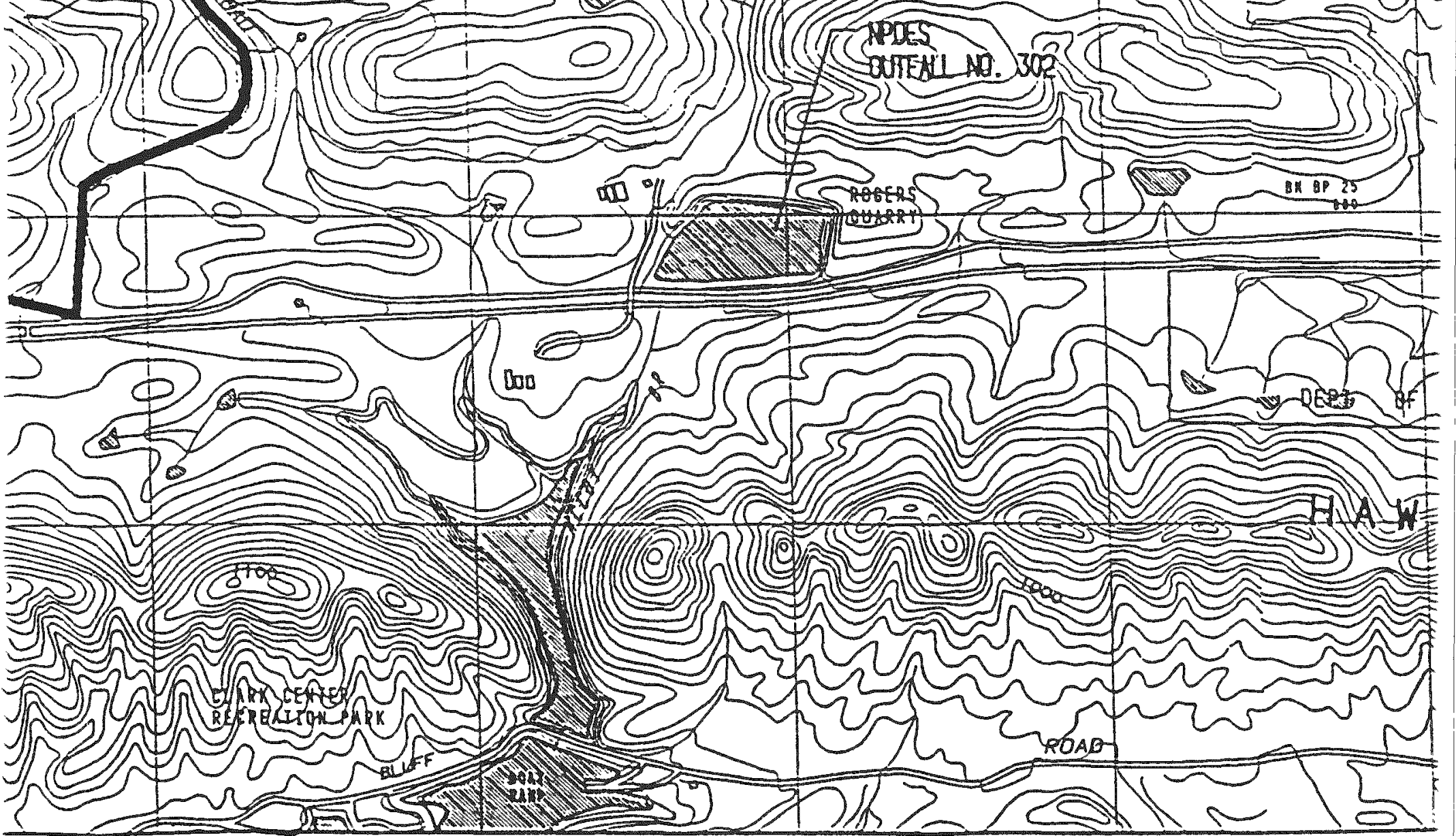

din
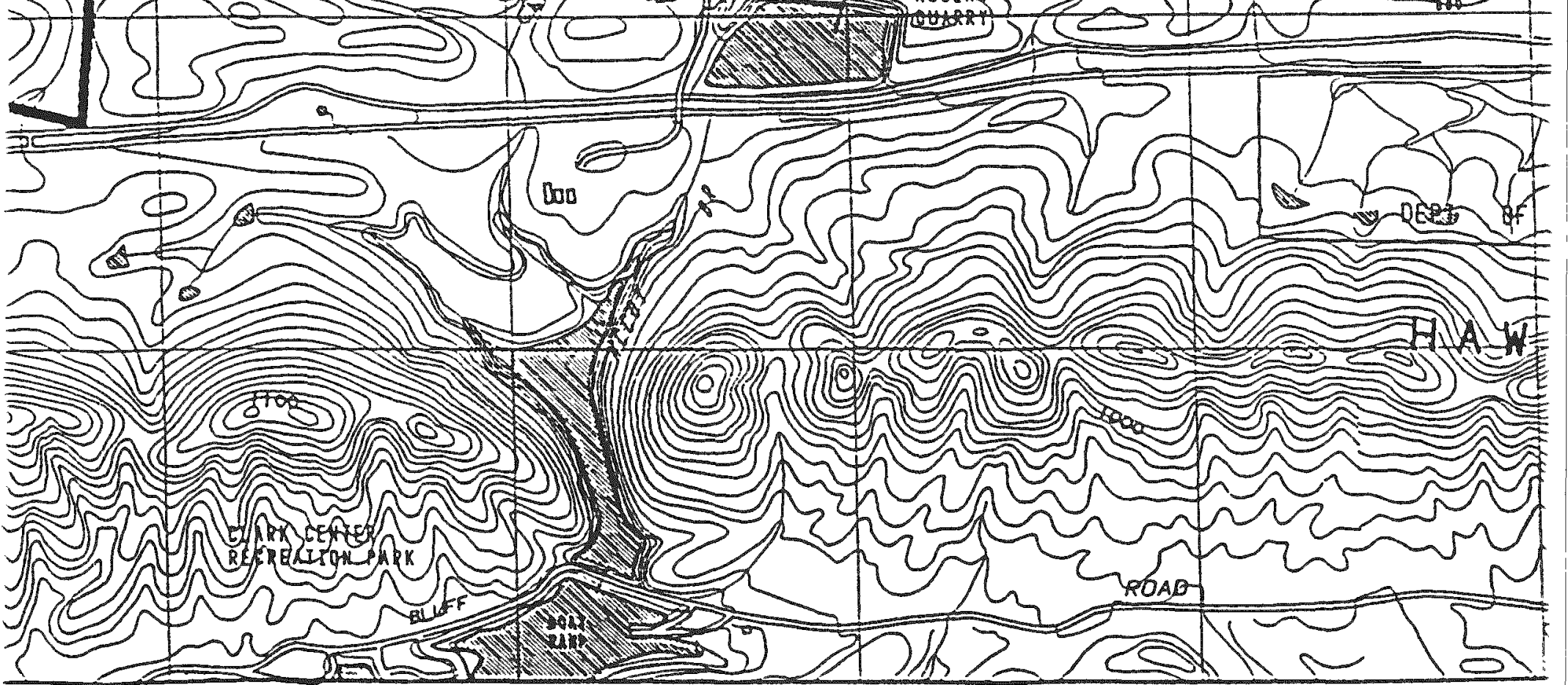


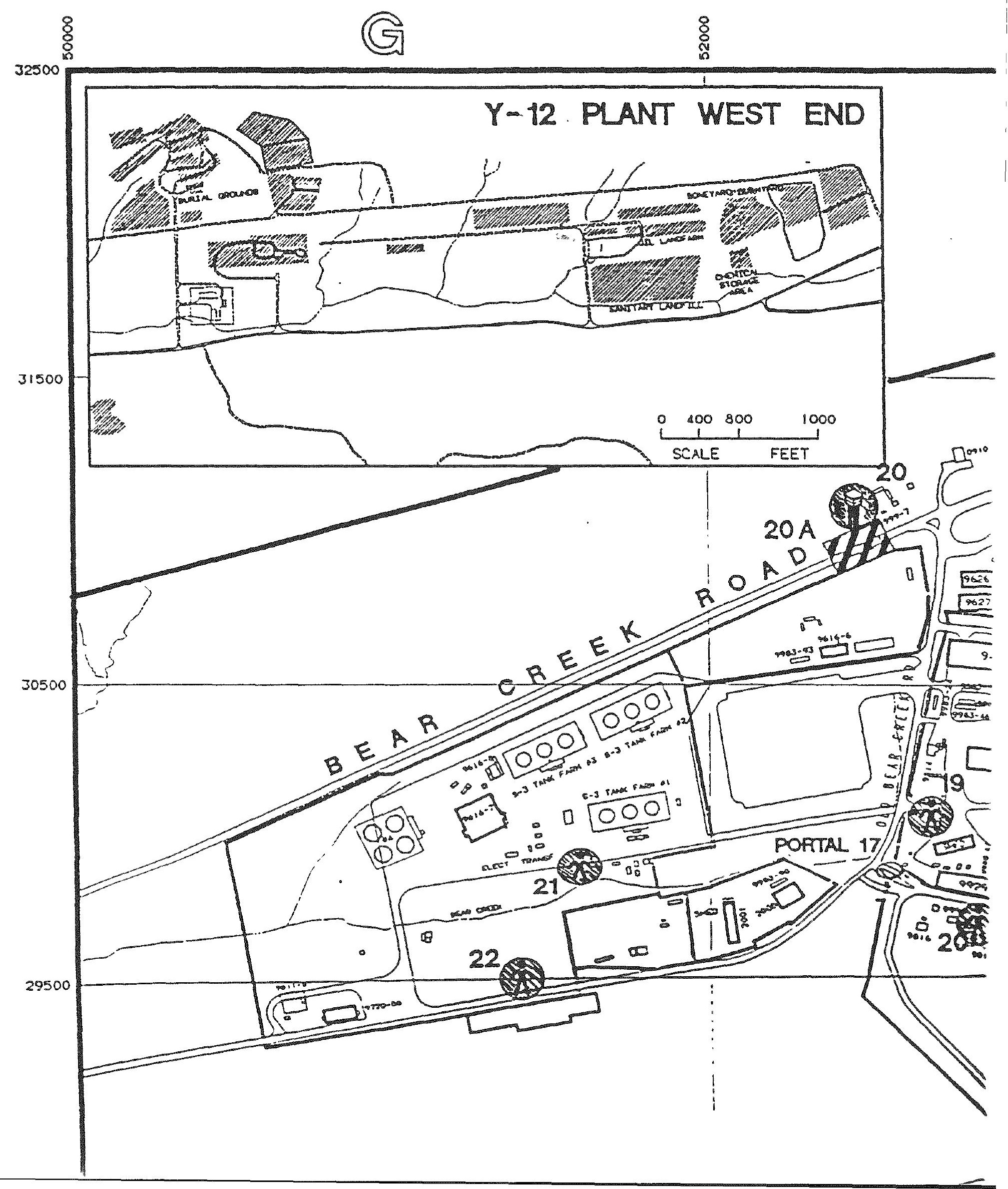



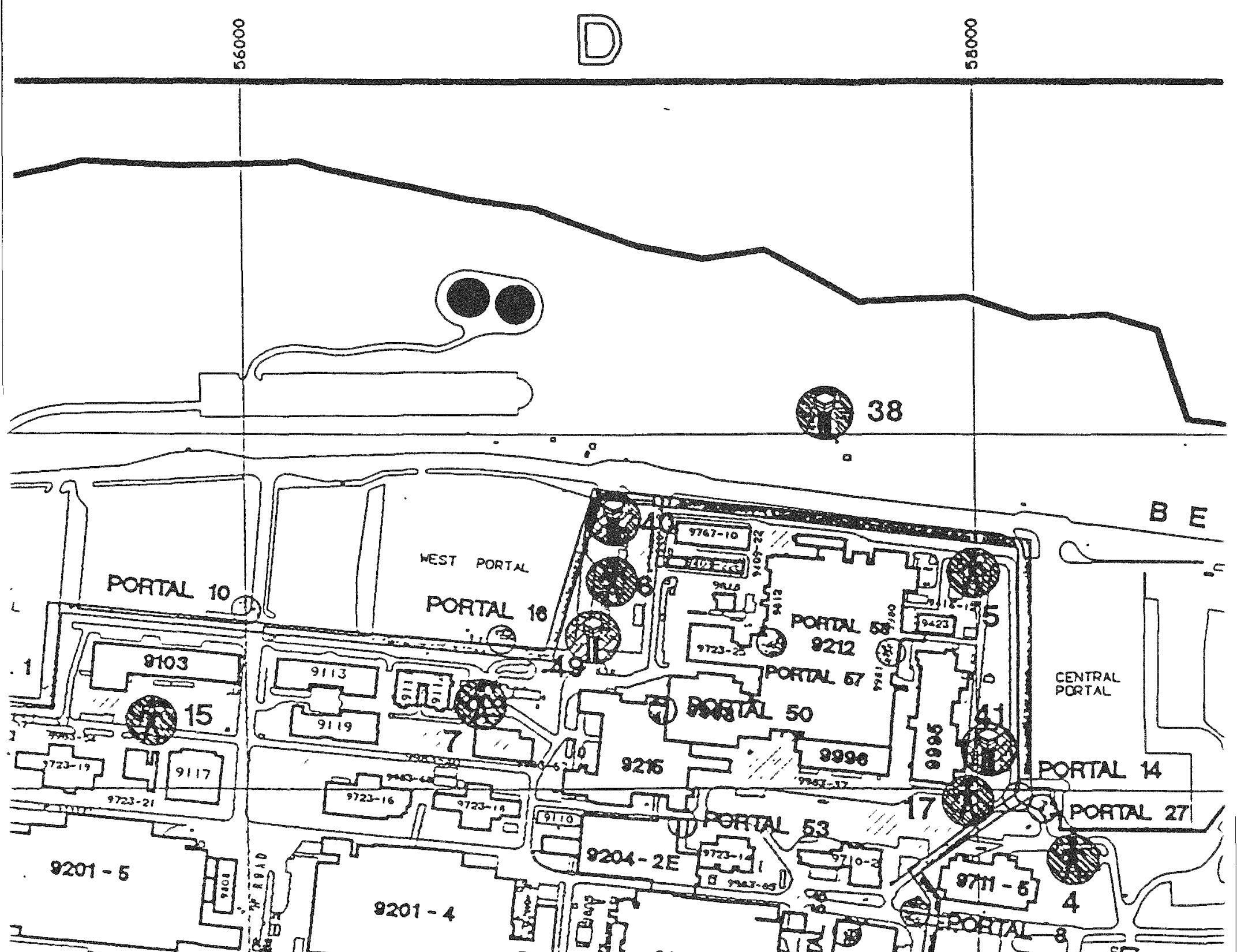

N.9.

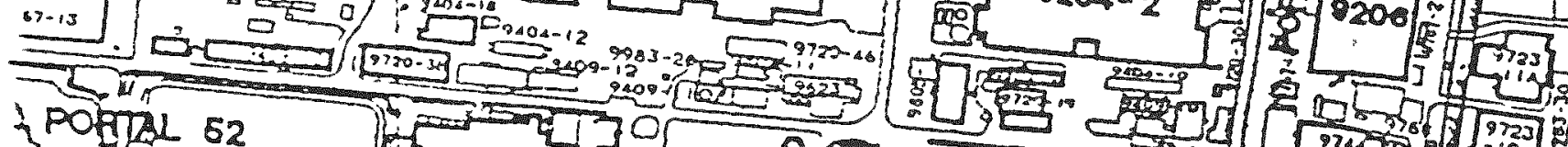

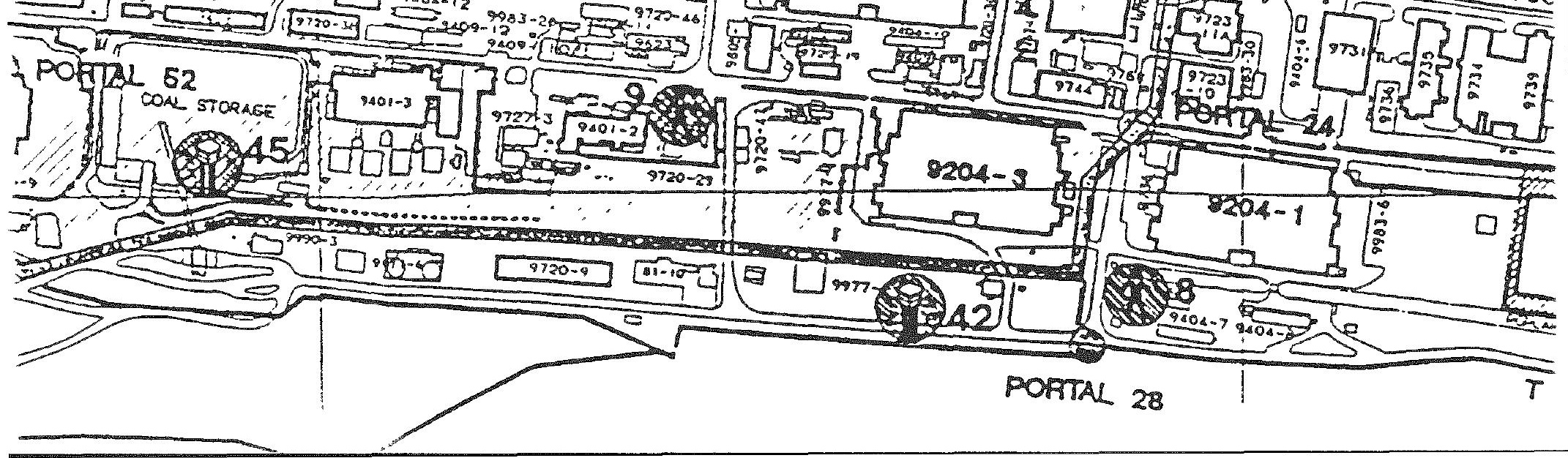




\section{FACILITIES MAP}

(C) B

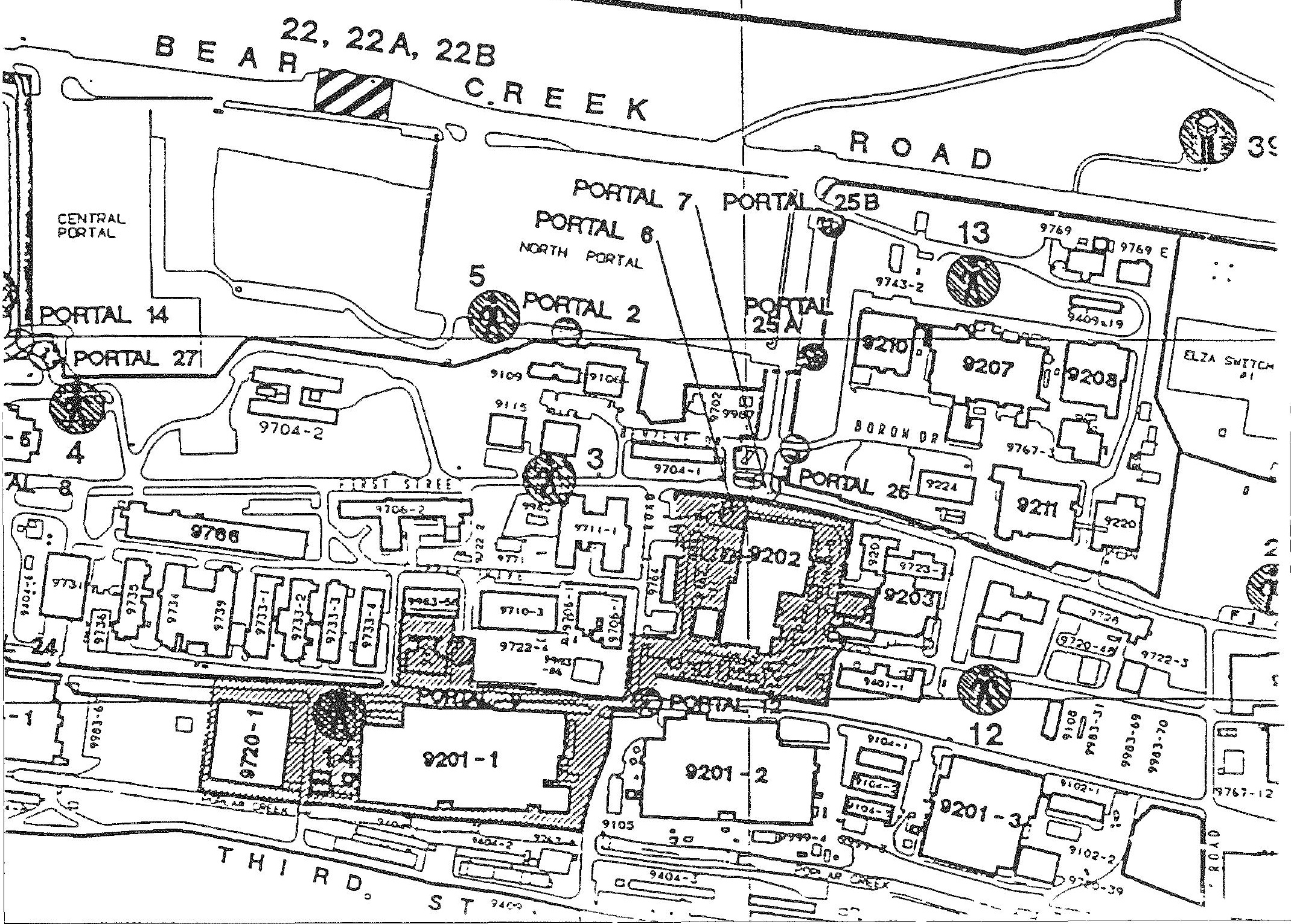


3)

ब

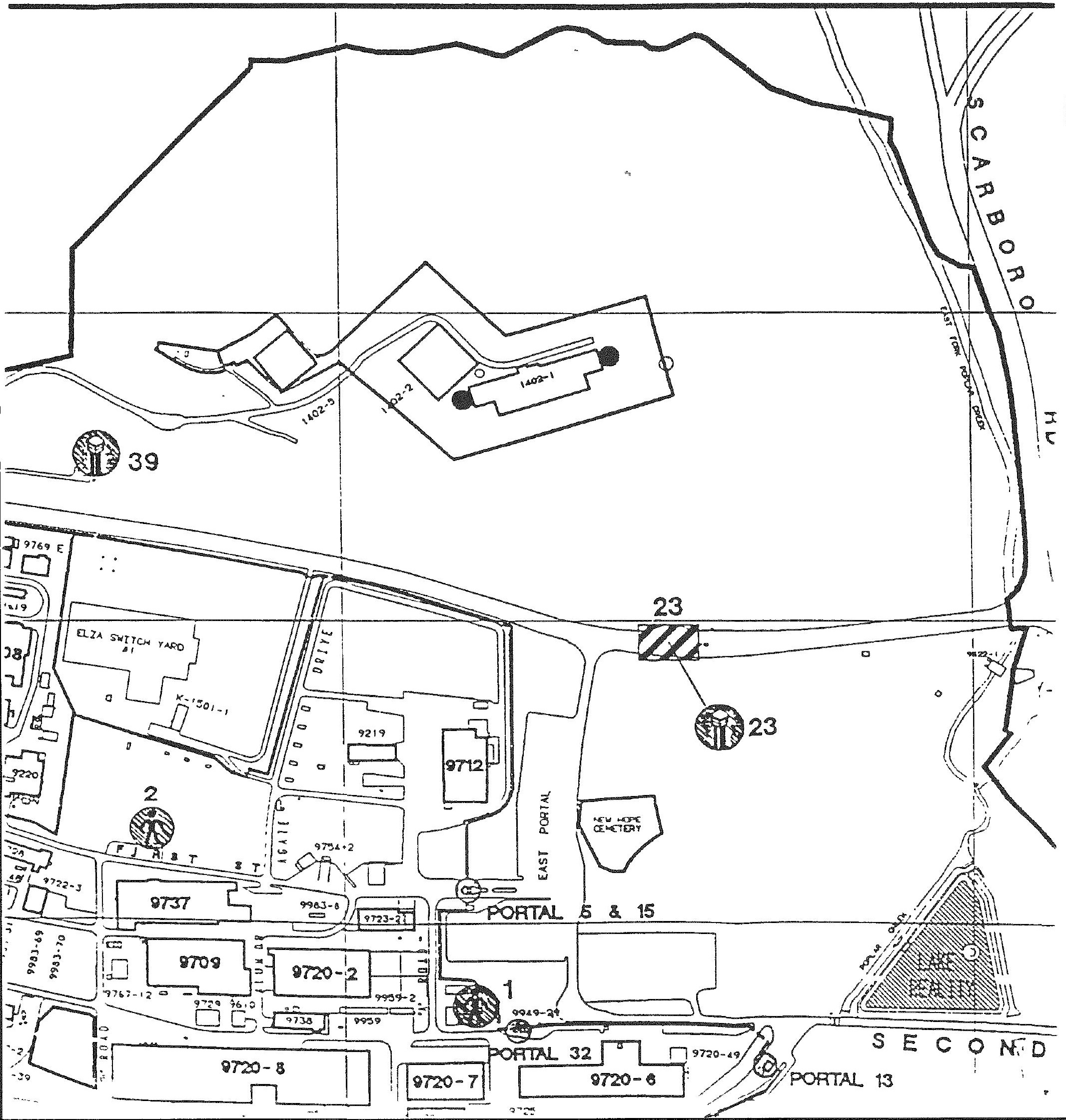


会会

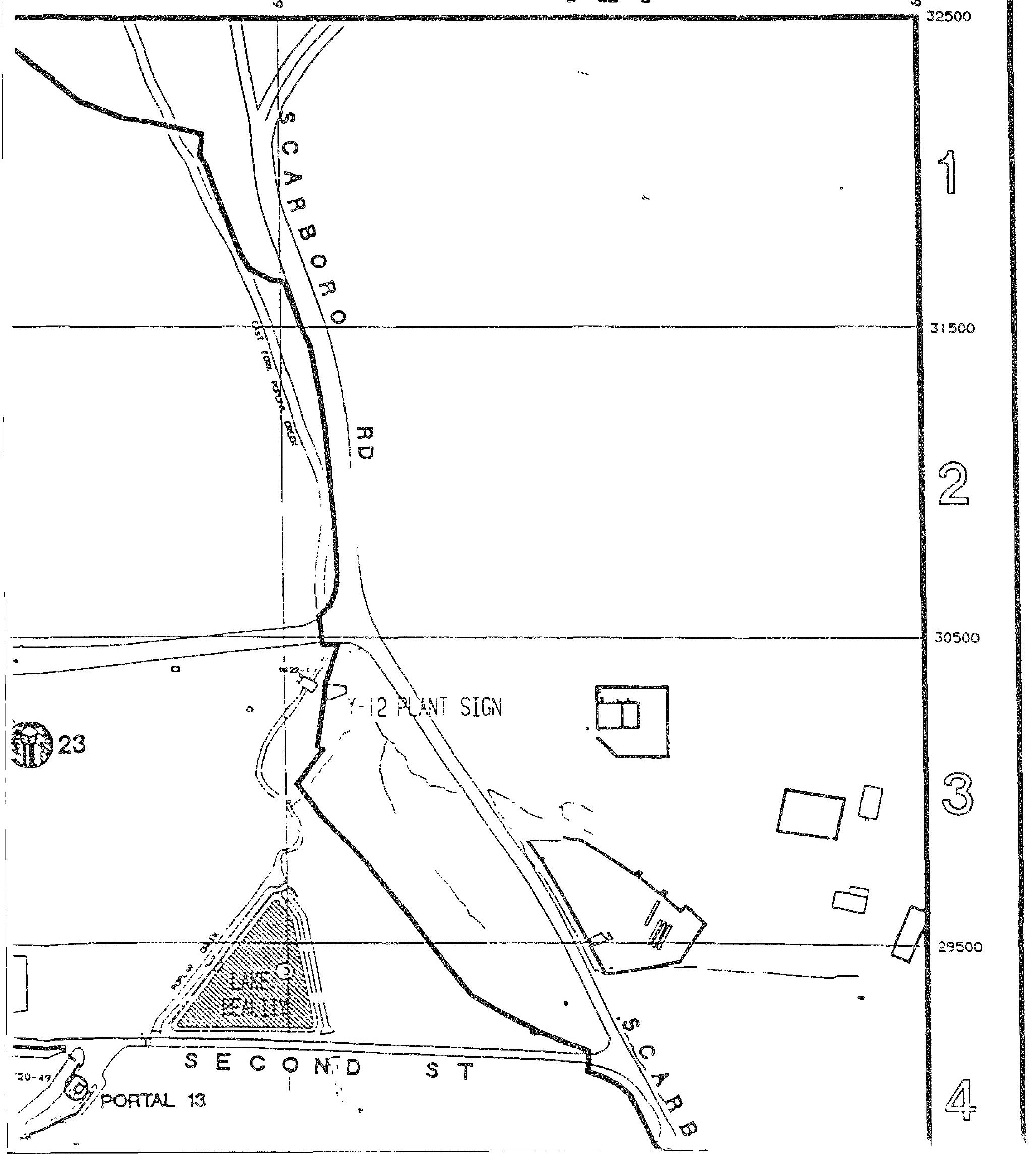



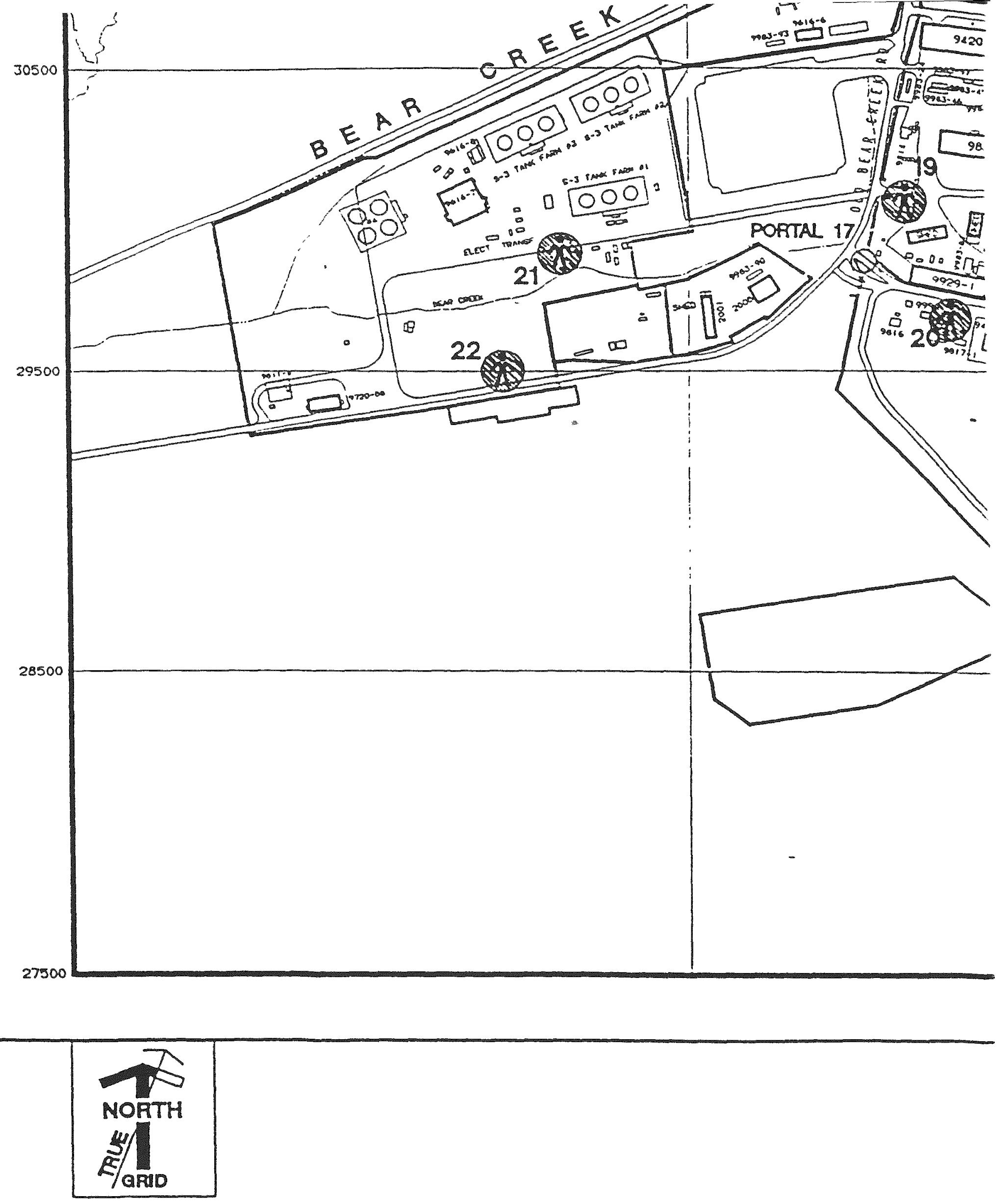

THE GRID AND COORDINATES AS SHOWN REPRESENT THE Y-12 PLANT GRID SYSTEM 


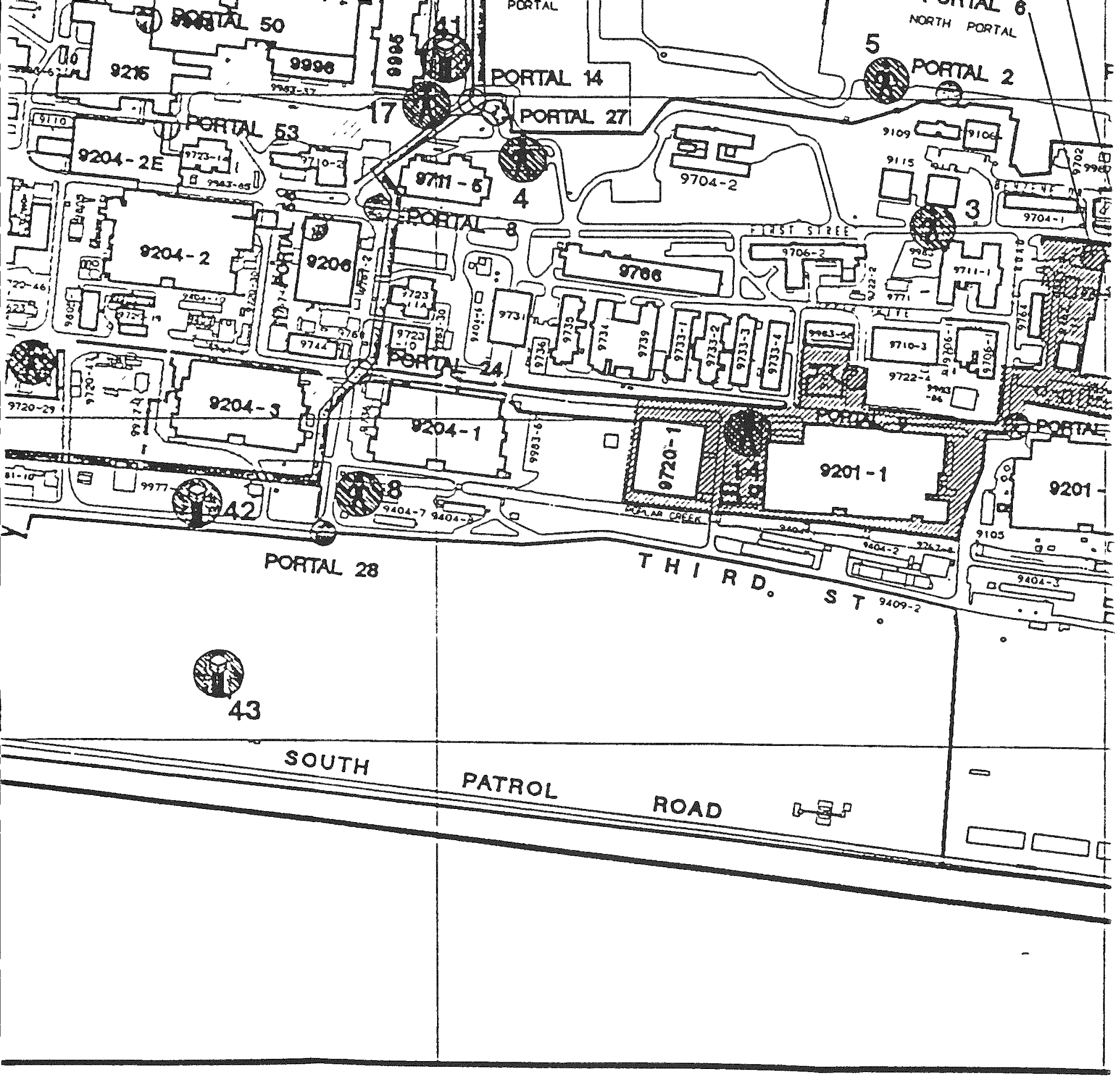

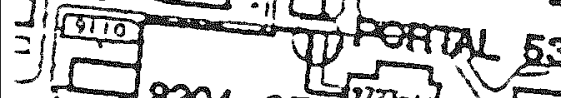 \\ Than}

1ै

I POATAL 27

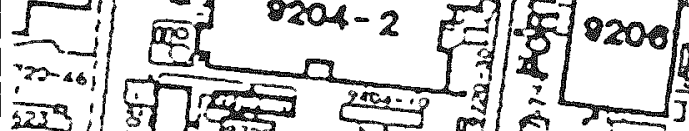

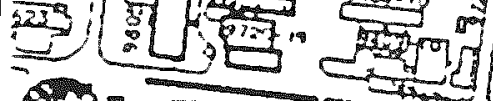

Th⿻

क्णि:

$\int_{6}=\sqrt{700}$ Sth

$-6$

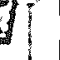




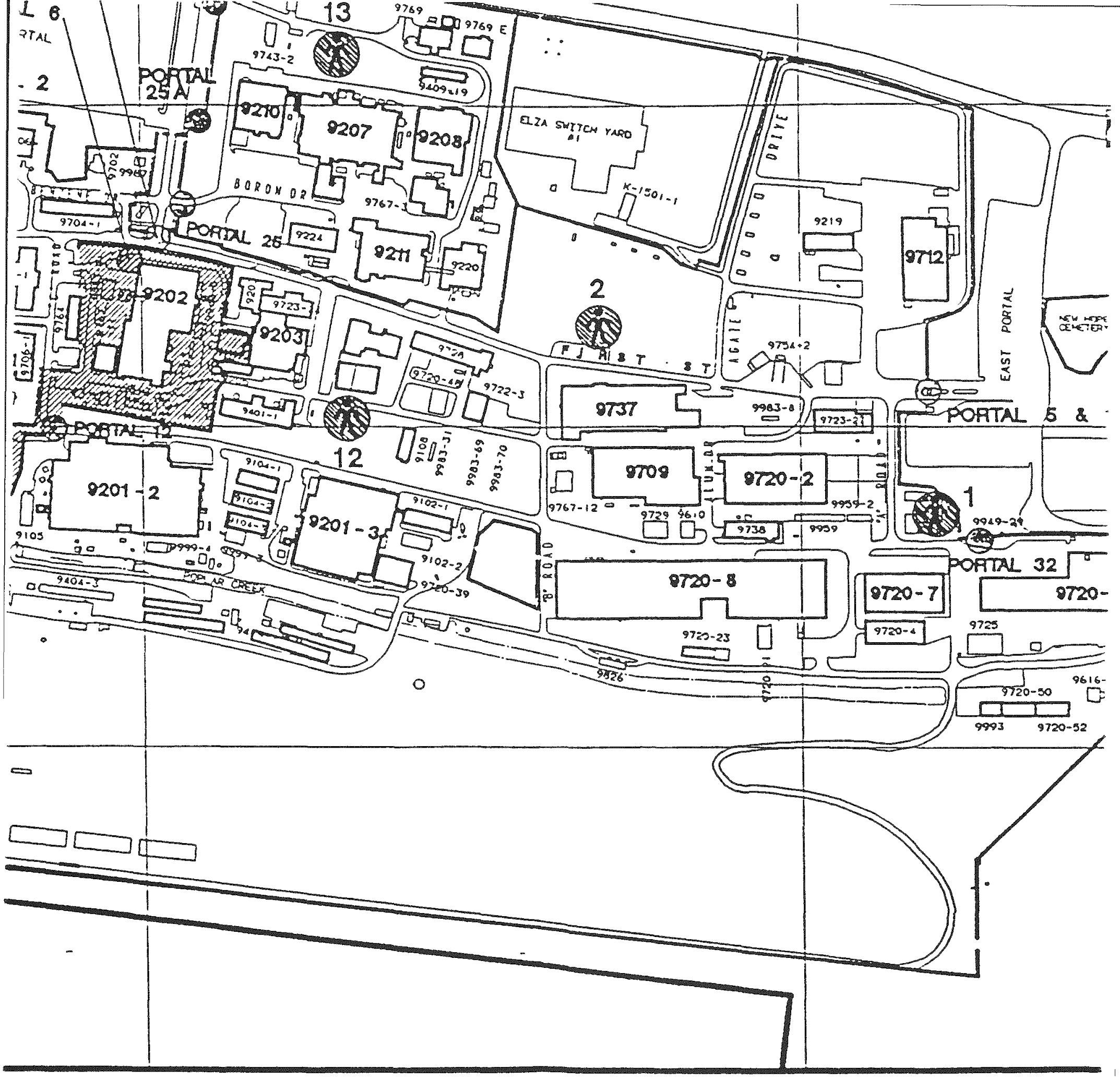

1

\section{GUARD TOWERS FENCING \\ assembly stations 229 fencing \\ - guard poRtals \\ OD VeHICULAR CHECK POINTS \\ $\frac{\text { PES/071/03089 }}{\text { PREPARED BY GEODA }}$ \\ SCALE}




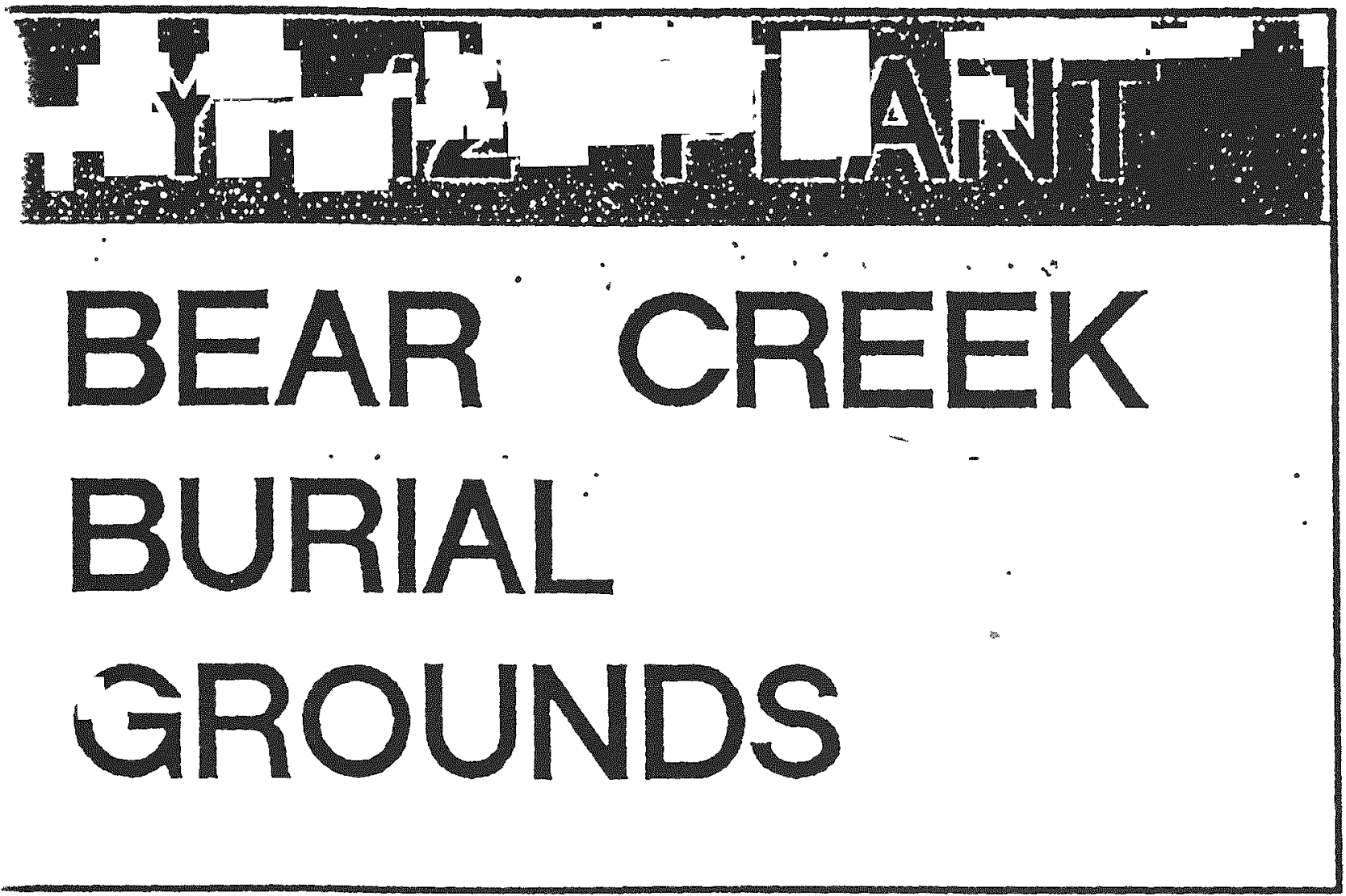

\section{LEGEND}

(1) DARA SOLIDS STORAGE UNIT

(2) DARA LIOUID STORAGE. \& TREATMENT UNIT

(3) INTERIM REACTIVE WASTE TREATMENT AREA

(4) OIL LANDFARM SOILS CONTAINMENT PAD

(5) WALK-IN PITS

(6) LiQuid organic solvent storage unit

- gamewell box locations

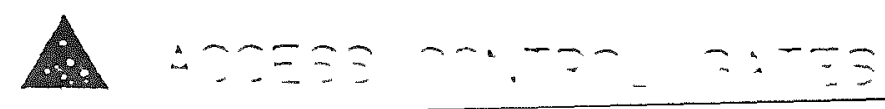




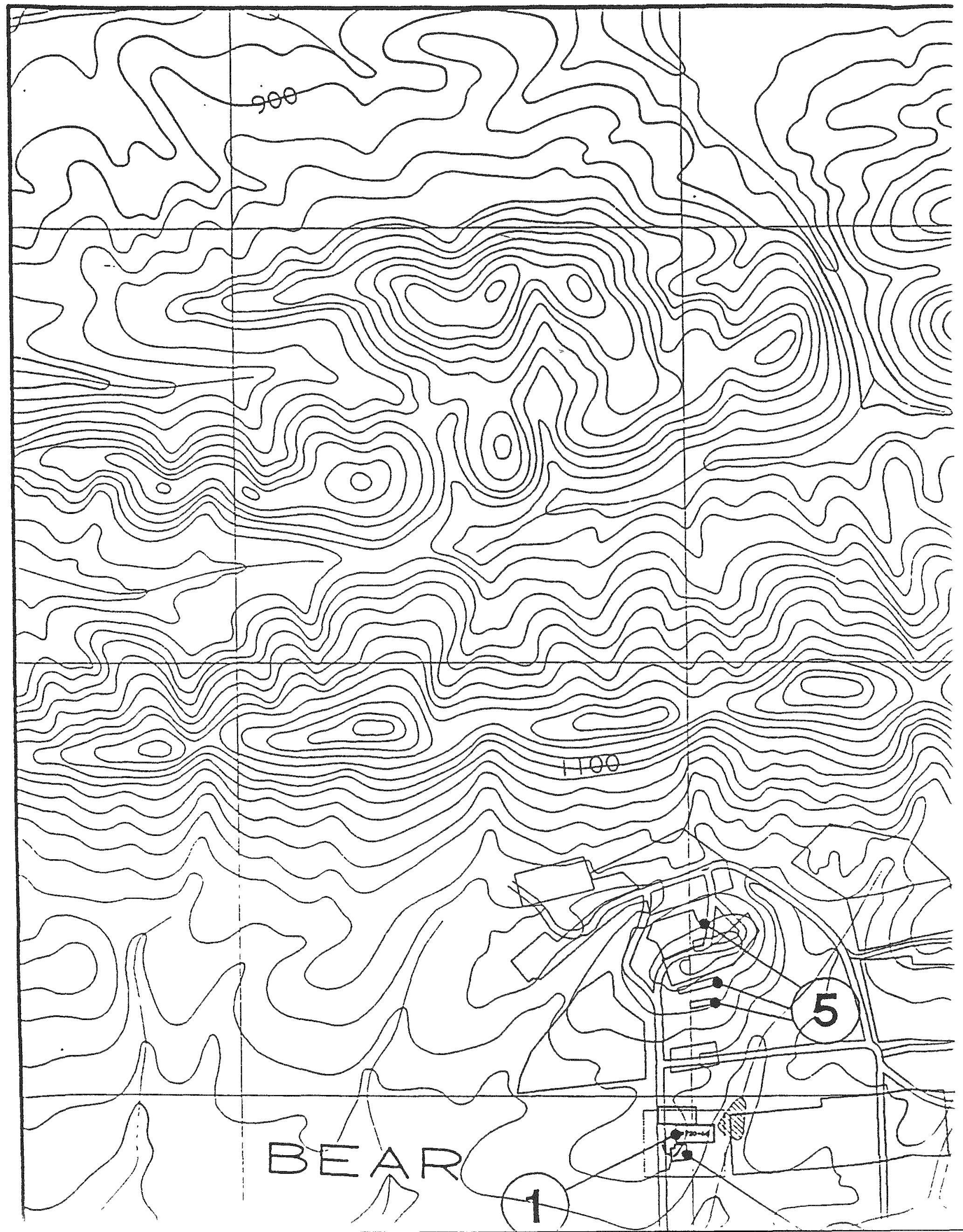




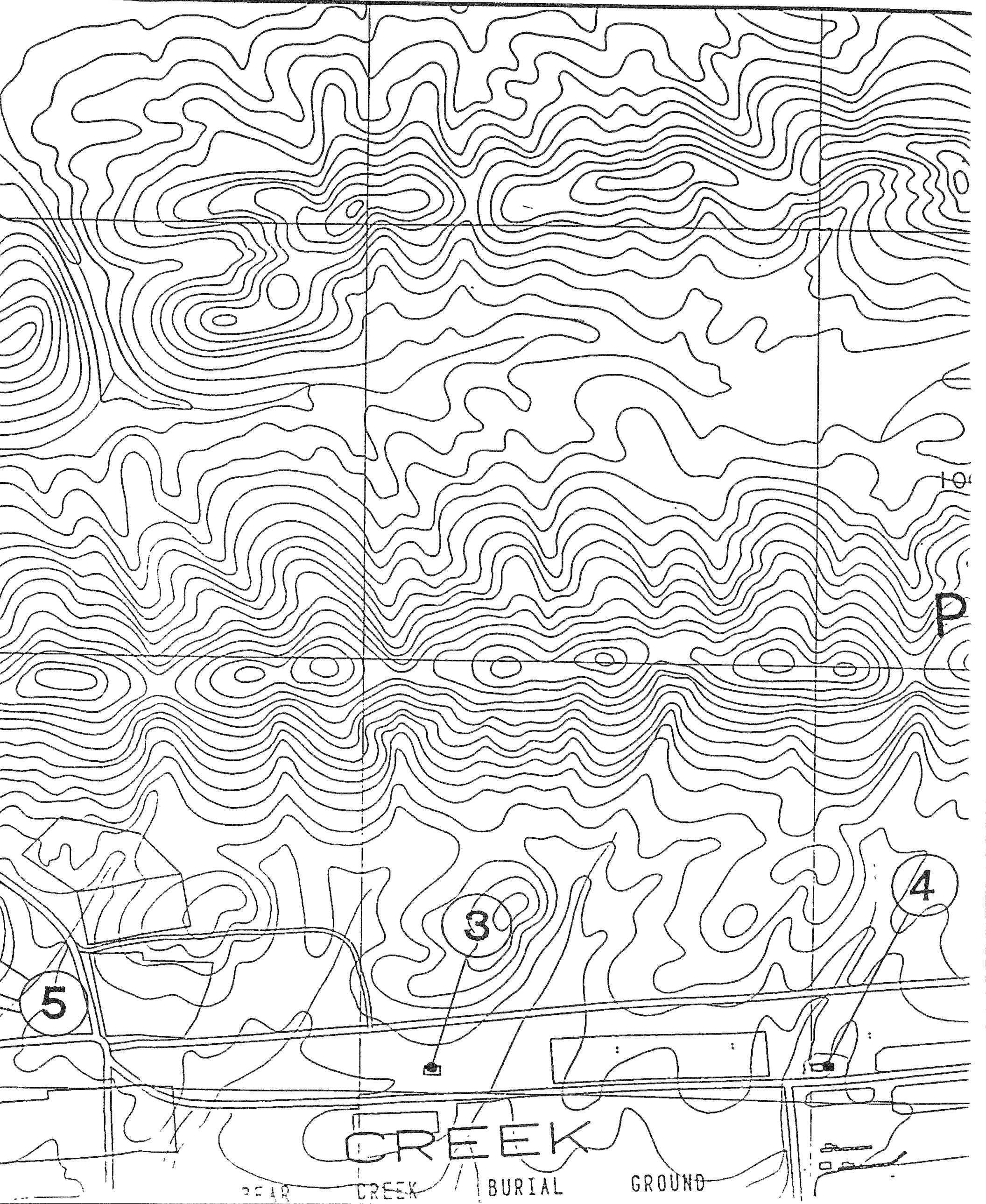




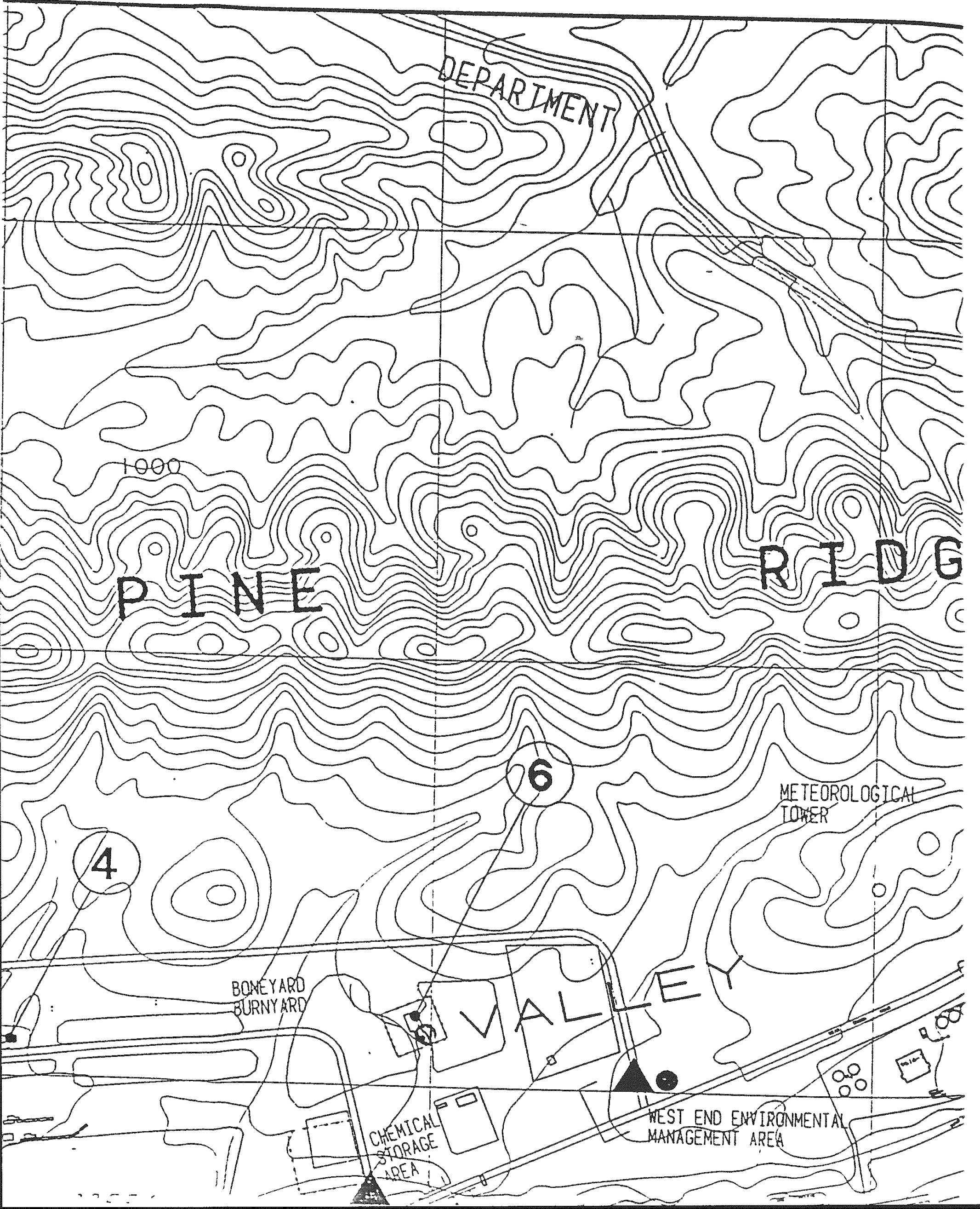




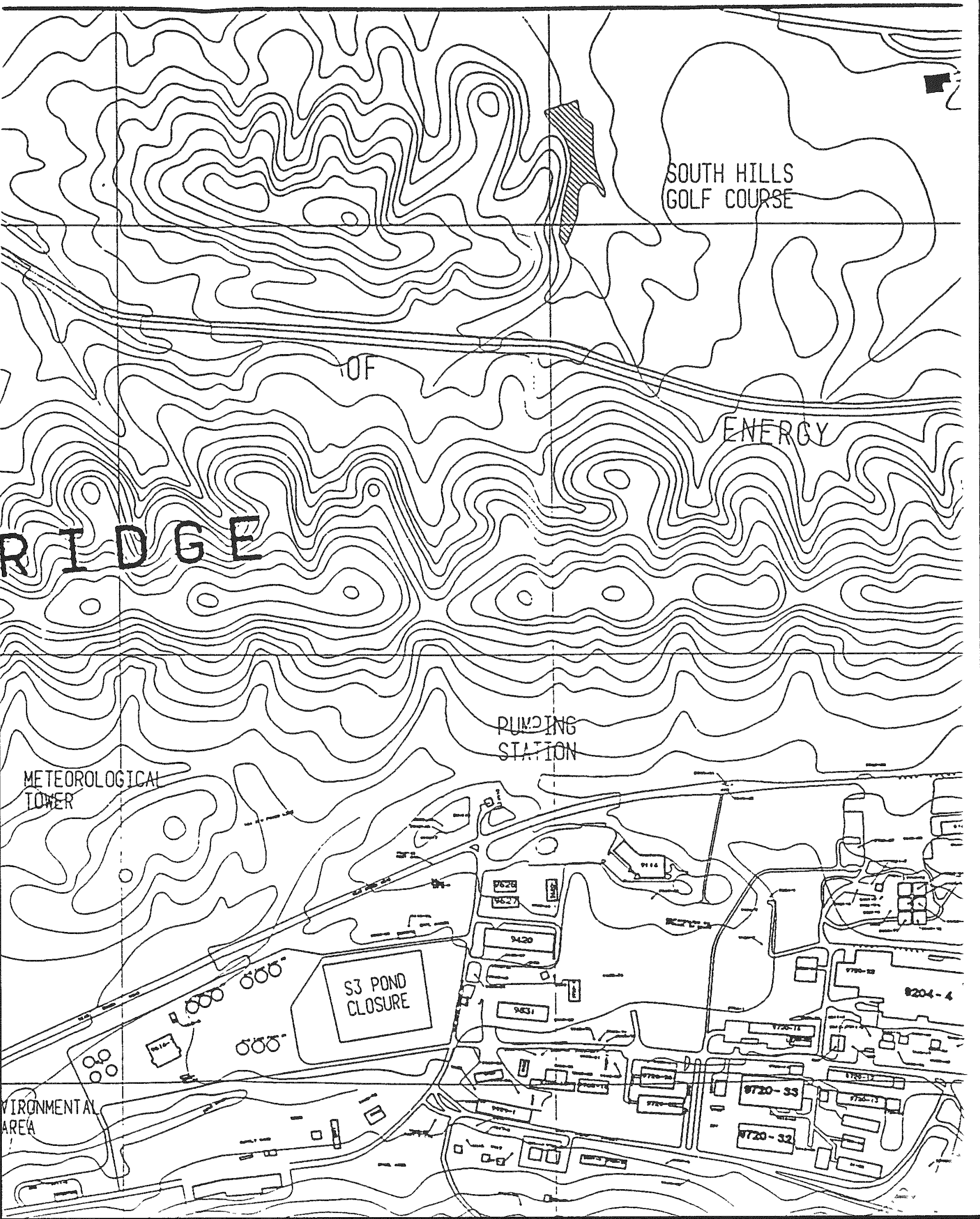


(1) DARA SOlidos STORAGE UNIT

(2) DARA LIOUID STORAGE. \& TREATMENT UNIT

(3) INTERIM REACTIVE WASTE TREATMENT AREA

(4) OIL LANDFARM SOILS CONTAINMENT PAD

(5) WALK-IN PITS

(6) LIOUID ORgANIC SOLVENT STORAGE UNIT

- gamewell boX locations

- access control gates

DOE 229 BOUNDARY

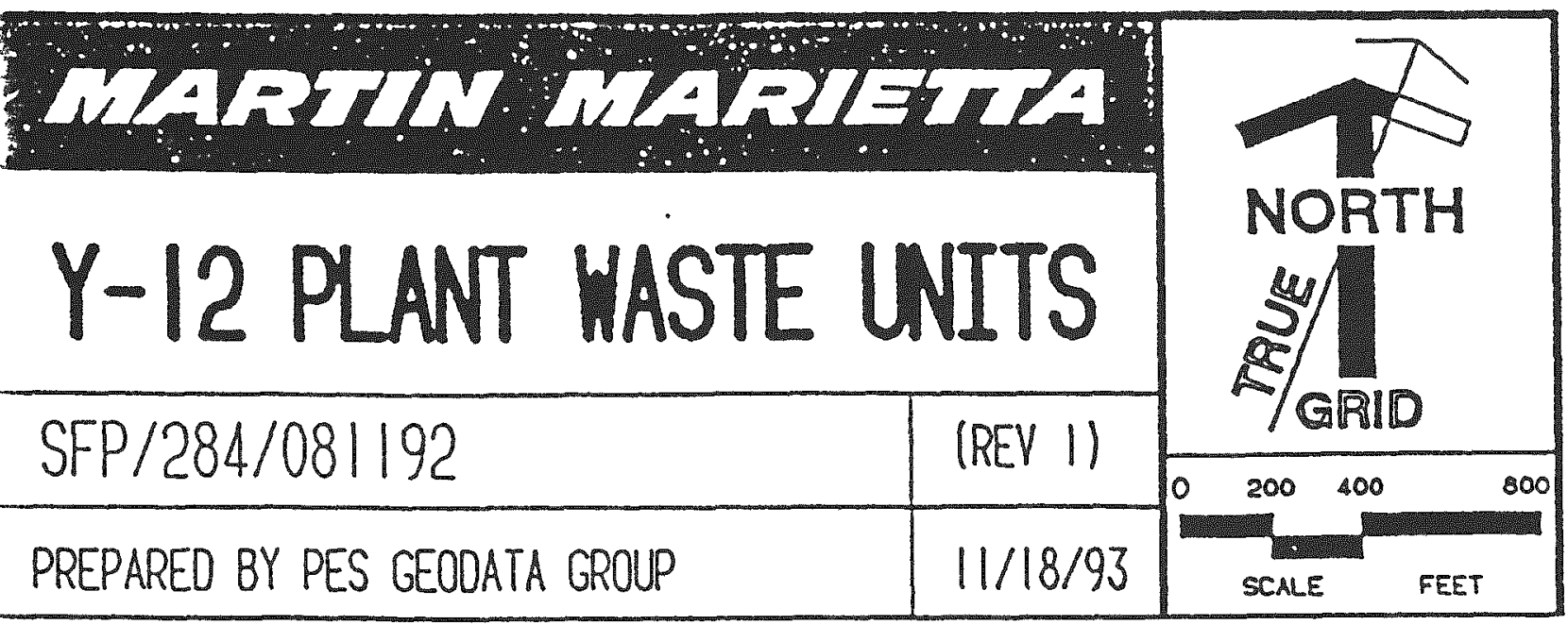




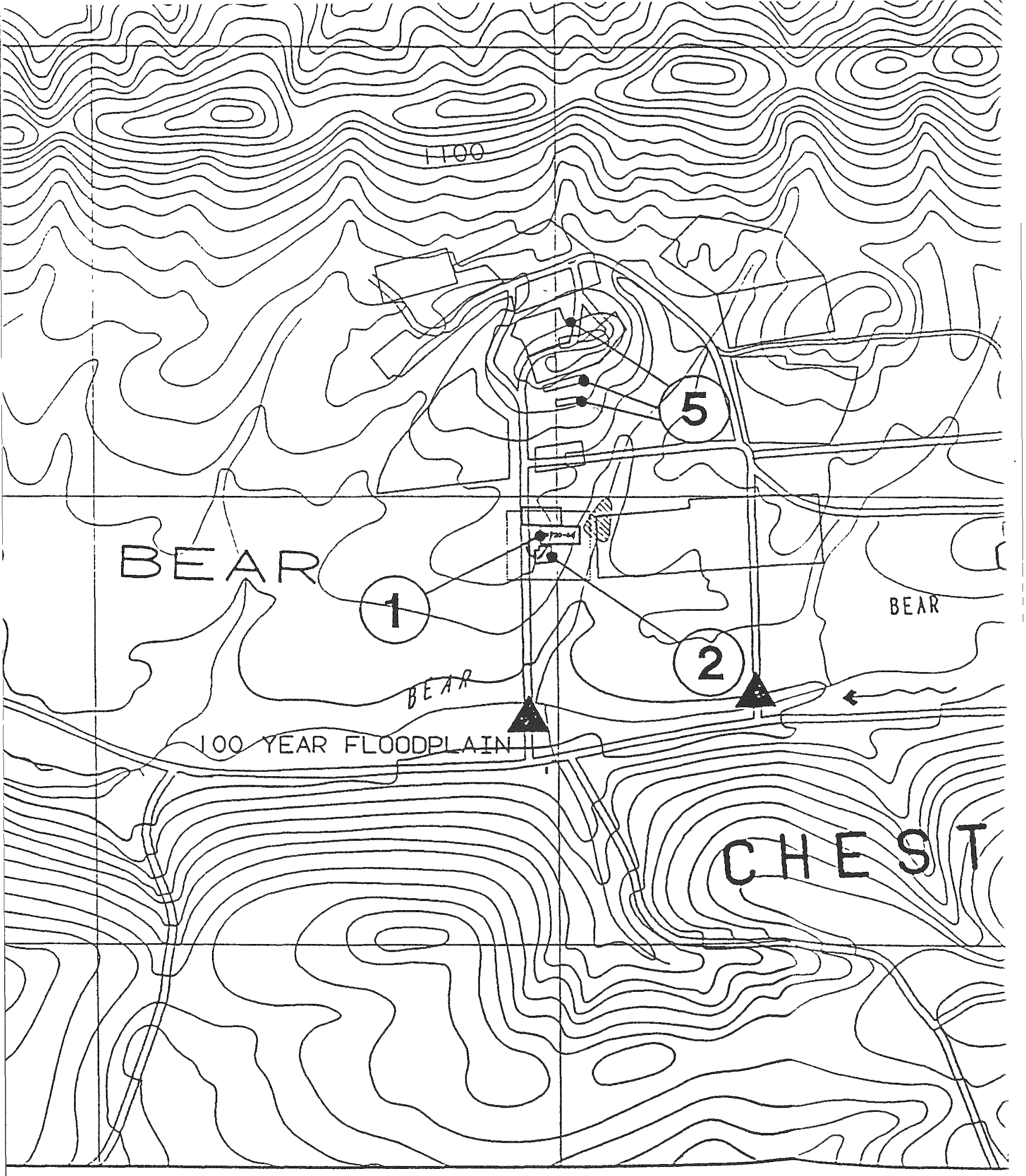




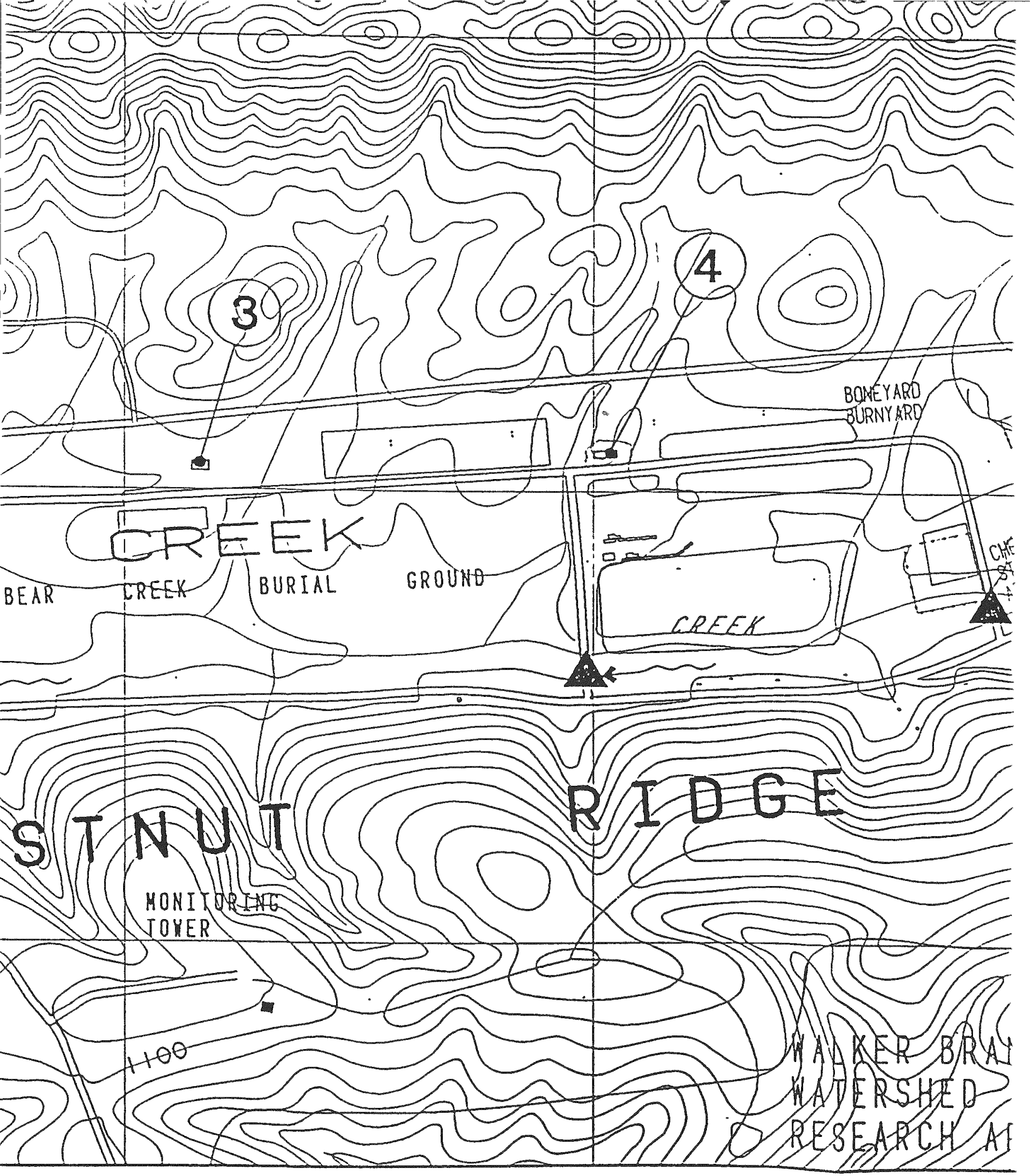




\section{乞n}

(2) (1)

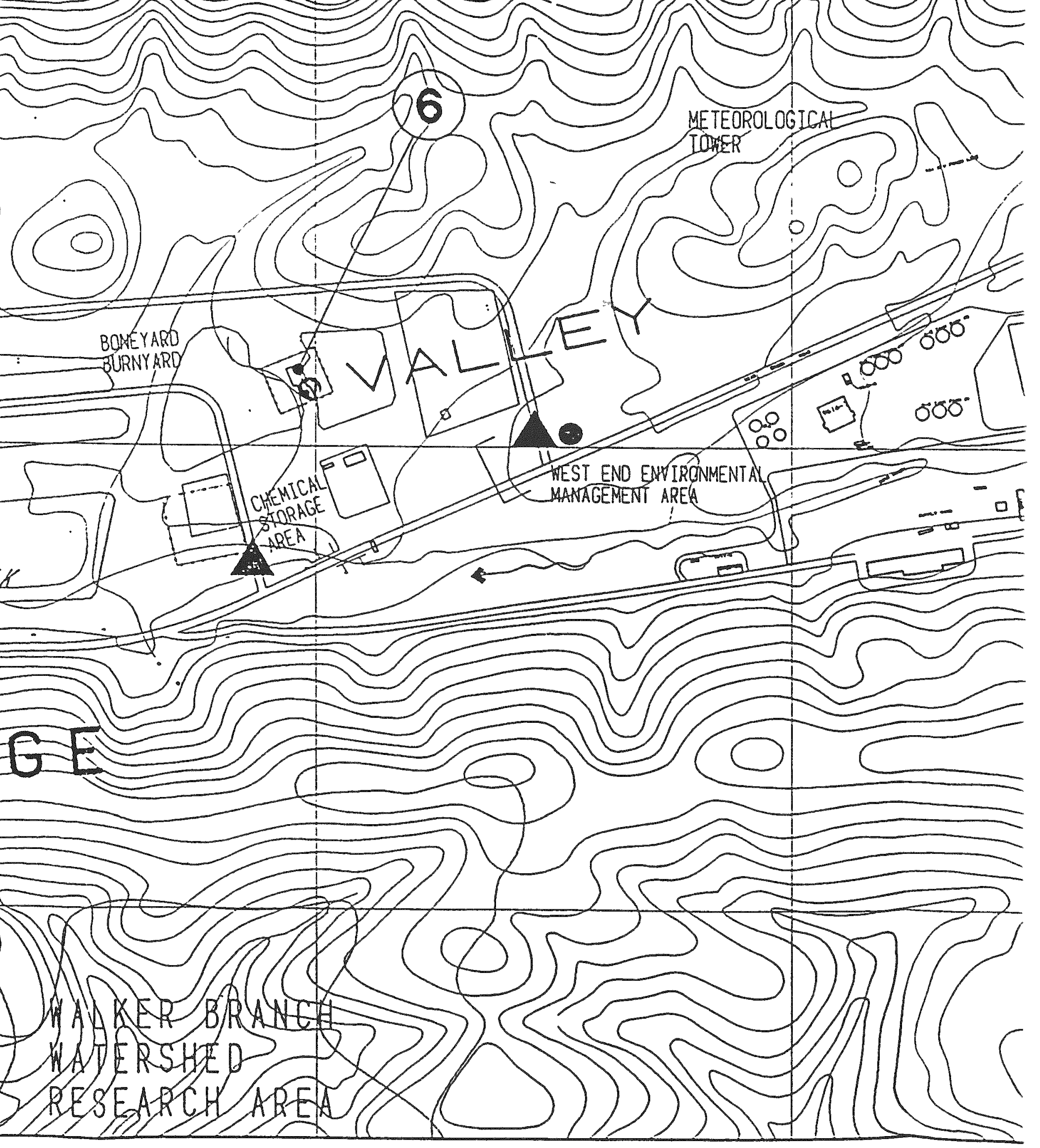




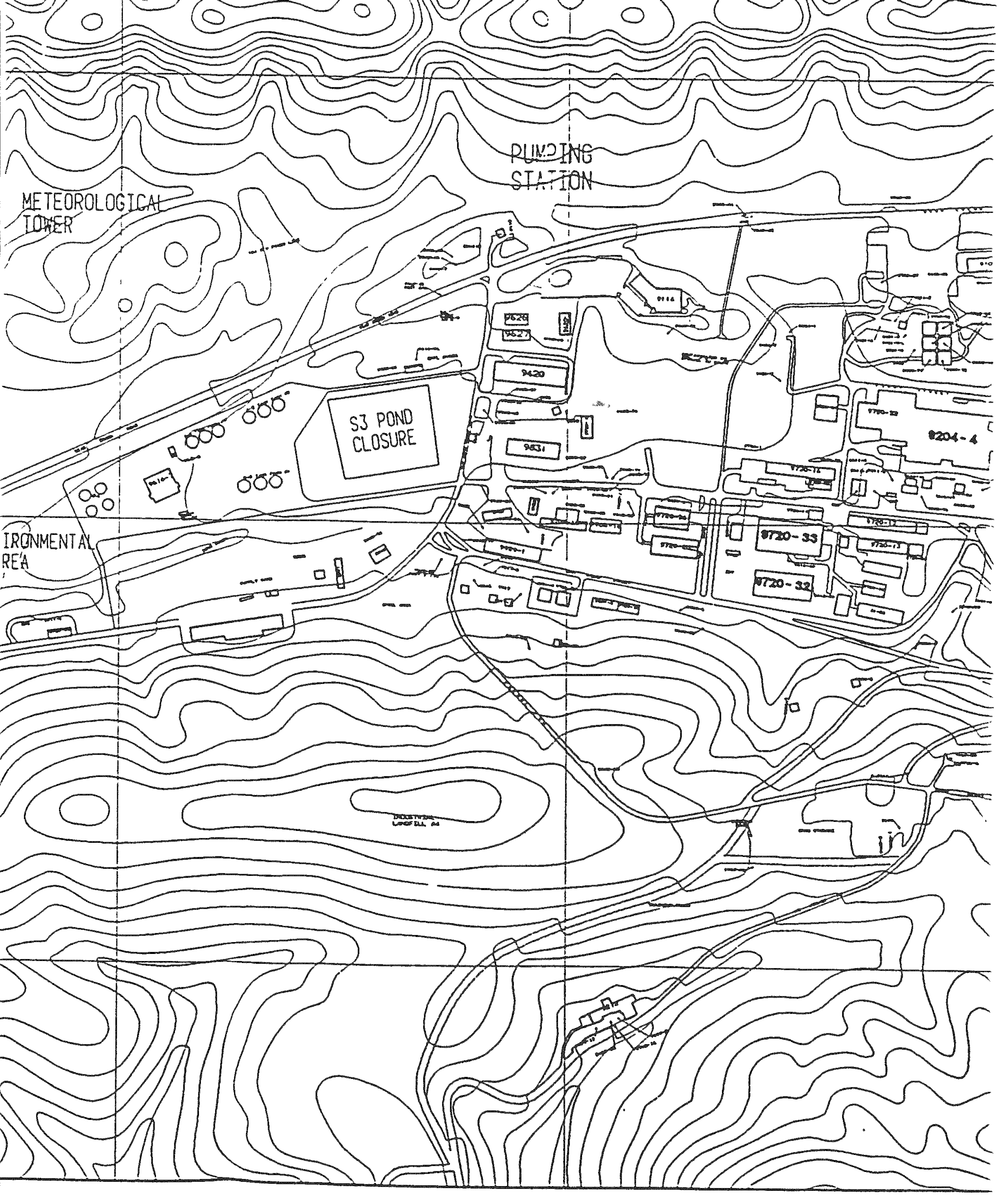




\section{OAK RIDGE Y-12 PLANT}

\section{EVACUATION ROUTES}

\begin{tabular}{lll}
\hline APPLICATION & EPA & DESCRIPTION \\
LITE & PROCESS OOOE & \\
\hline
\end{tabular}

I............... CYANIDE TREATMENT UNIT

SOI

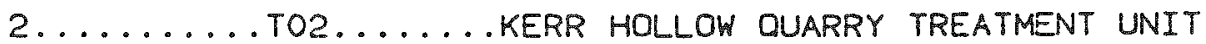

3........SO2.....GARAGE UNDERGROUNO TANKS

$4 \ldots \ldots \ldots$.........WALK - IN PITS

$5 \ldots \ldots \ldots$. . . . . . . INTERIM DRUM YARD

$6 \ldots \ldots \ldots$. SOI....... BUILDING 9720-9 STORAGE UNIT

$7 \ldots \ldots \ldots . . . . . . .$. RCRA \& MIXED WASTE STORAGE \&

STAGING BUILDING 9720-31

$8 \ldots \ldots$. . . . . . . BUILDING $9811-1$ RCRA

TANK STORAGE UNIT

9......... SO1...... BUILDING $9811-1$ RCRA

CONTA INER STORAGE UNIT

$10 \ldots \ldots \ldots$. SO2......WASTE OIL/SOLVENT STORAGE UNIT

SO i

$11 \ldots \ldots . .$. SO2......LIO. ORGANIC SOLVENT STOR. UNIT

sol

$12 \ldots \ldots \ldots . . . . . . . .503 \ldots$ EAST CHESTNUT RIDGE WASTE PILE

$13 \ldots \ldots \ldots$. . . . . . . CONTAINERIZED WASTE STORAGE AREA

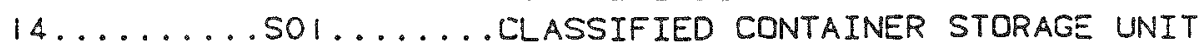
BUILDING 9720-25

$15 \ldots \ldots \ldots . .503 \ldots . .$. OIL LANDFARM SOILS CONTAINMT. PAD

$16 \ldots . \ldots . . .503 \ldots . .$. DISPOSAL AREA REMEDIAL ACTION

(DARA) SOLIDS STORAGE UNIT

$17 \ldots \ldots \ldots$ TO $\ldots . \ldots .$. URANIUM TREATMENT UNIT

SOI

$18 \ldots \ldots \ldots$ TO $4 \ldots . . .$. INTERIM REACTIVE WASTE TREATMT AREA

$19 \ldots \ldots . . .501 \ldots \ldots$. . . BUILOING 9720-12 CLASSIFIED

CONTAINER STORAGE AREA

$20 \ldots \ldots . . .501 \ldots \ldots$ RCRA AND PCB CONTAINER

STORAGE AREA. BUILDING 9720-58

$21 \ldots \ldots . .$. SO $\ldots . .$. BUILOING $9201-\triangle$ CONTAINER

STORAGE AREA

$22 \ldots . \ldots . . .501 \ldots . .$. BUILDING 9206 CONTAINER STORAGE AREA

$23 \ldots \ldots \ldots$............ BUILOING 9212 CONTAINER STORAGE AREA

$24 \ldots \ldots \ldots$......... BLDG 9409-5 STORAGE UNIT

$25 \ldots \ldots . . .501 \ldots . . .3 L D G$ 9720-32 PRODUCTION WASTE

STORAGE UNIT (FUTURE)

$26 \ldots . . . .501 \ldots . .$. BLDG 9720-59 CLASSIFIED WASTE

STORAGE UNIT (FUTURE)

$27 \ldots . . .$. SO $1 \ldots .$. . OAK RIDGE RESERVATION STORAGE UNITS (FUTURE)

\section{LEGEND}

BEAR CREEK ROAD

SCARBORO ROAD

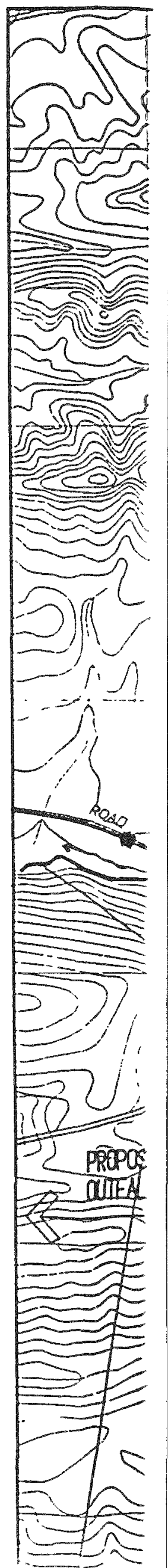




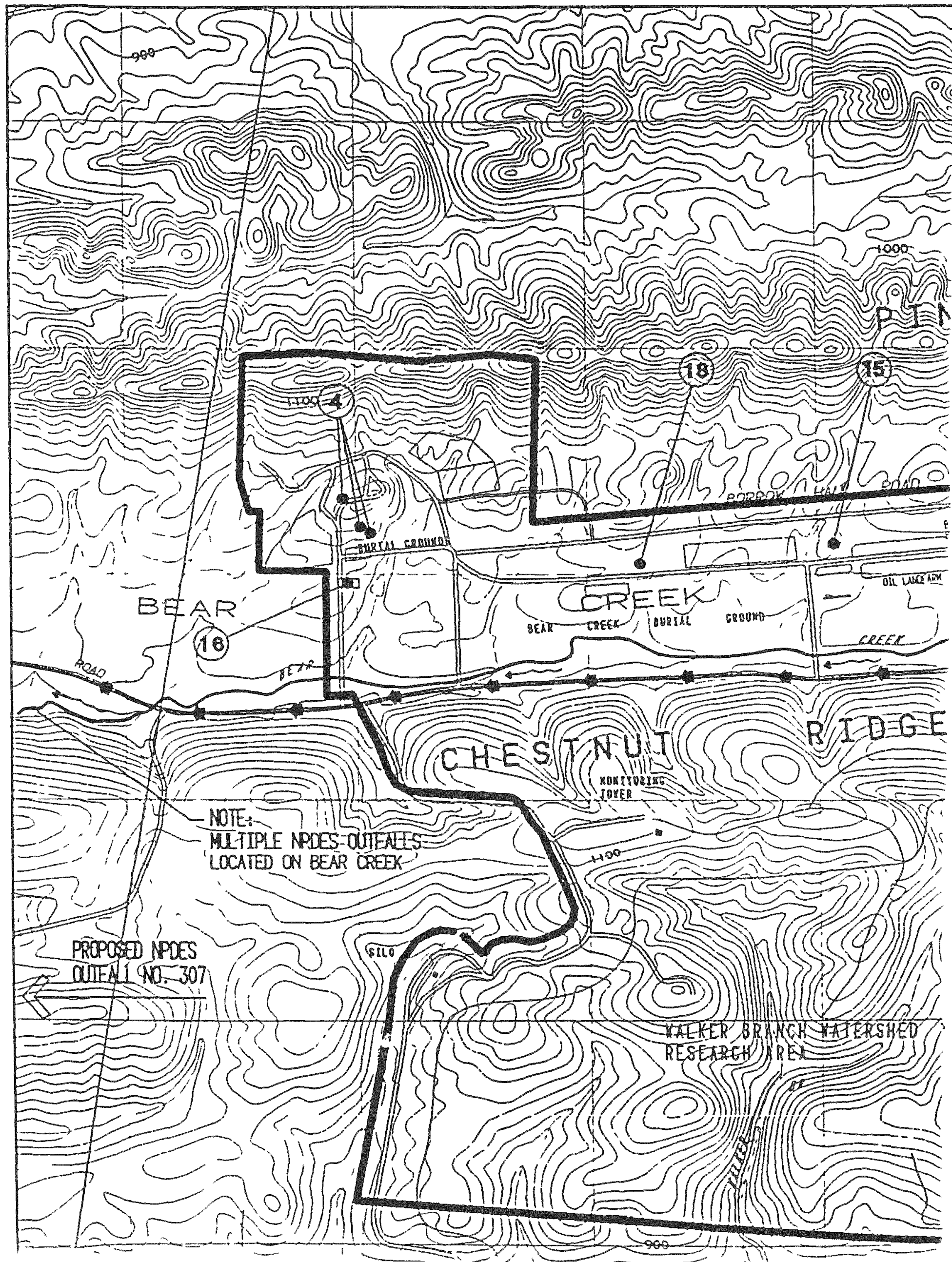




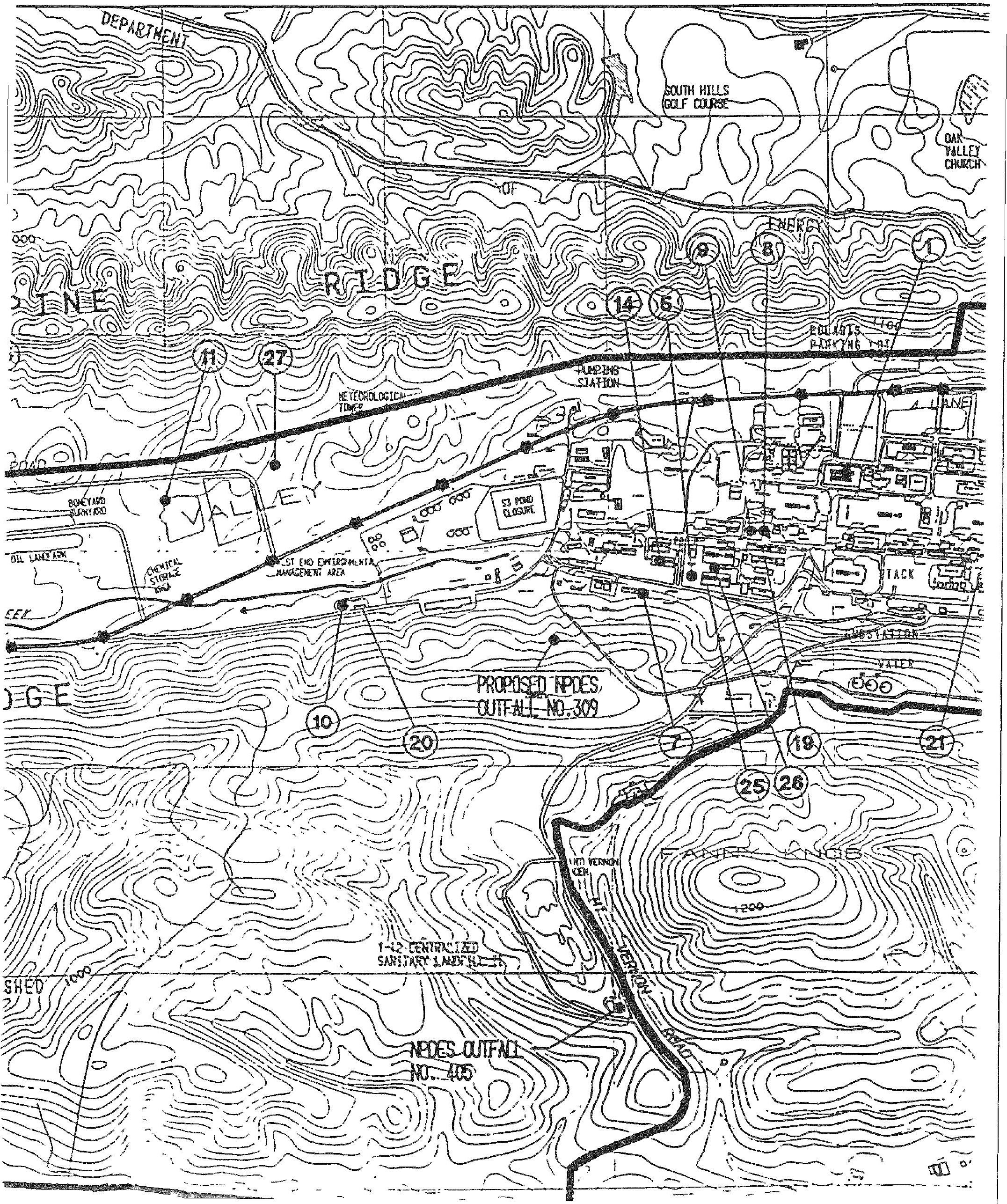



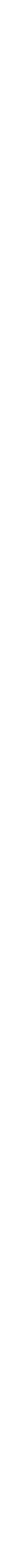
$\sqrt{ }$

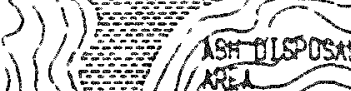
(13) $(24)$
(12)

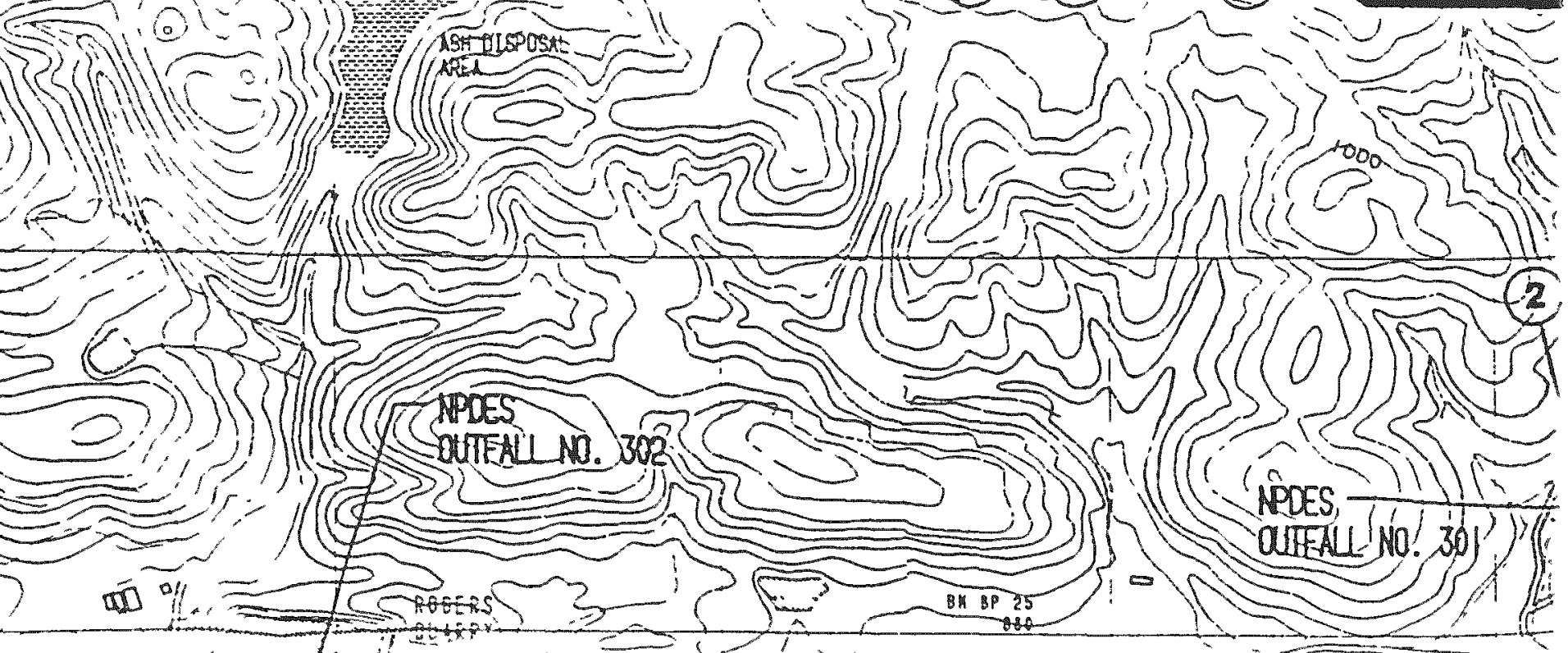




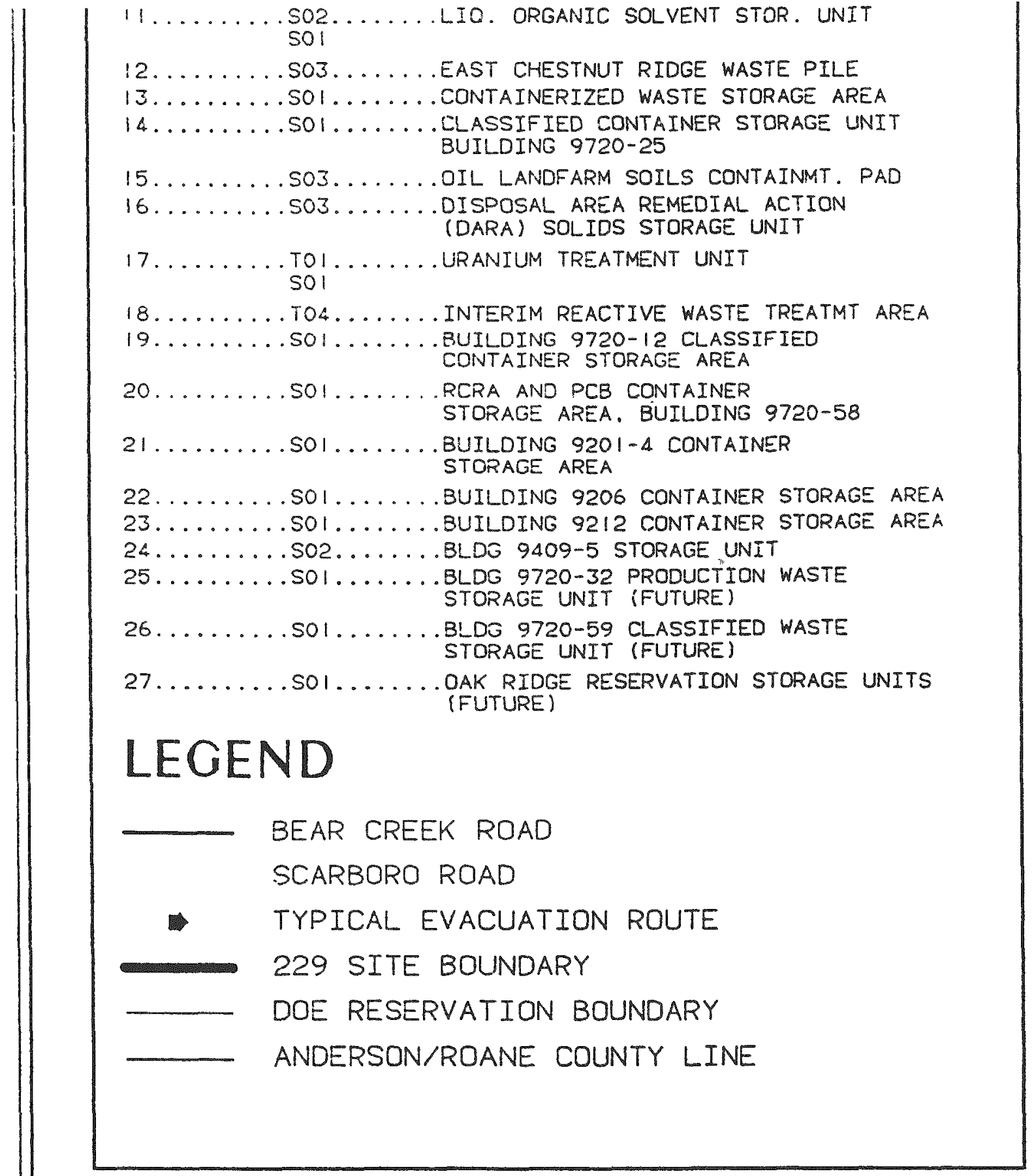

\section{MZARINW MLARTETLA ENERGY SYSTEMS, INC.}

\section{Y-12 PLANT EVACUATION ROUTES}

SCNE

\begin{tabular}{|c|c|}
\hline CV/GIS-496/041694 & (REY O) \\
\hline $\begin{array}{l}\text { PREPARED BY CIVIL BAGINEEERING/ } \\
\text { GIS APQICATIONS CONIER }\end{array}$ & avid/ss \\
\hline
\end{tabular}

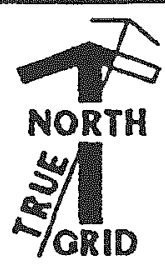

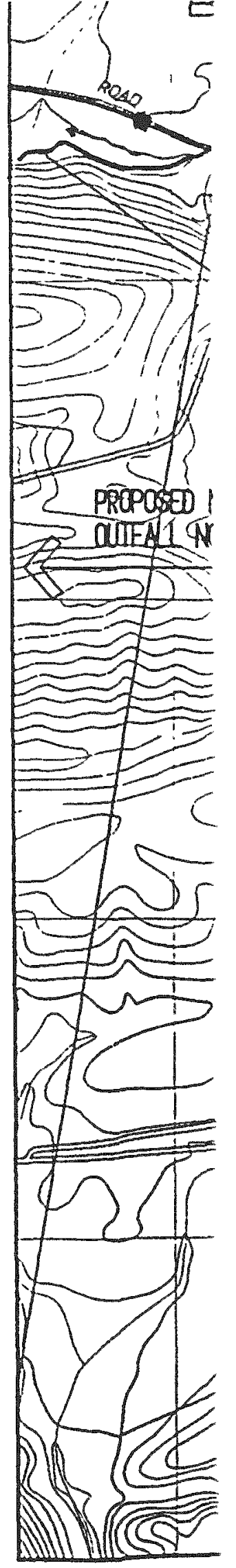




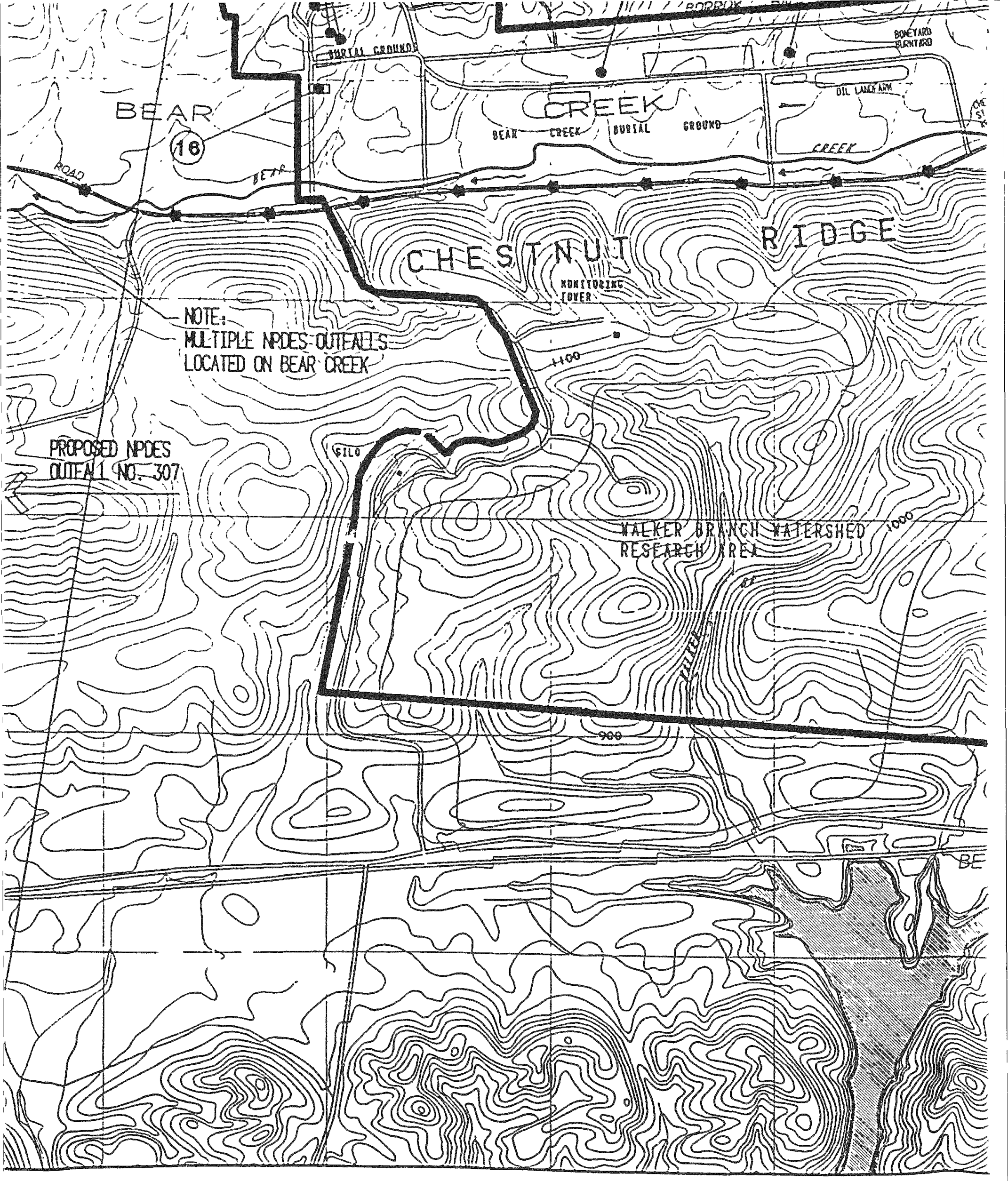




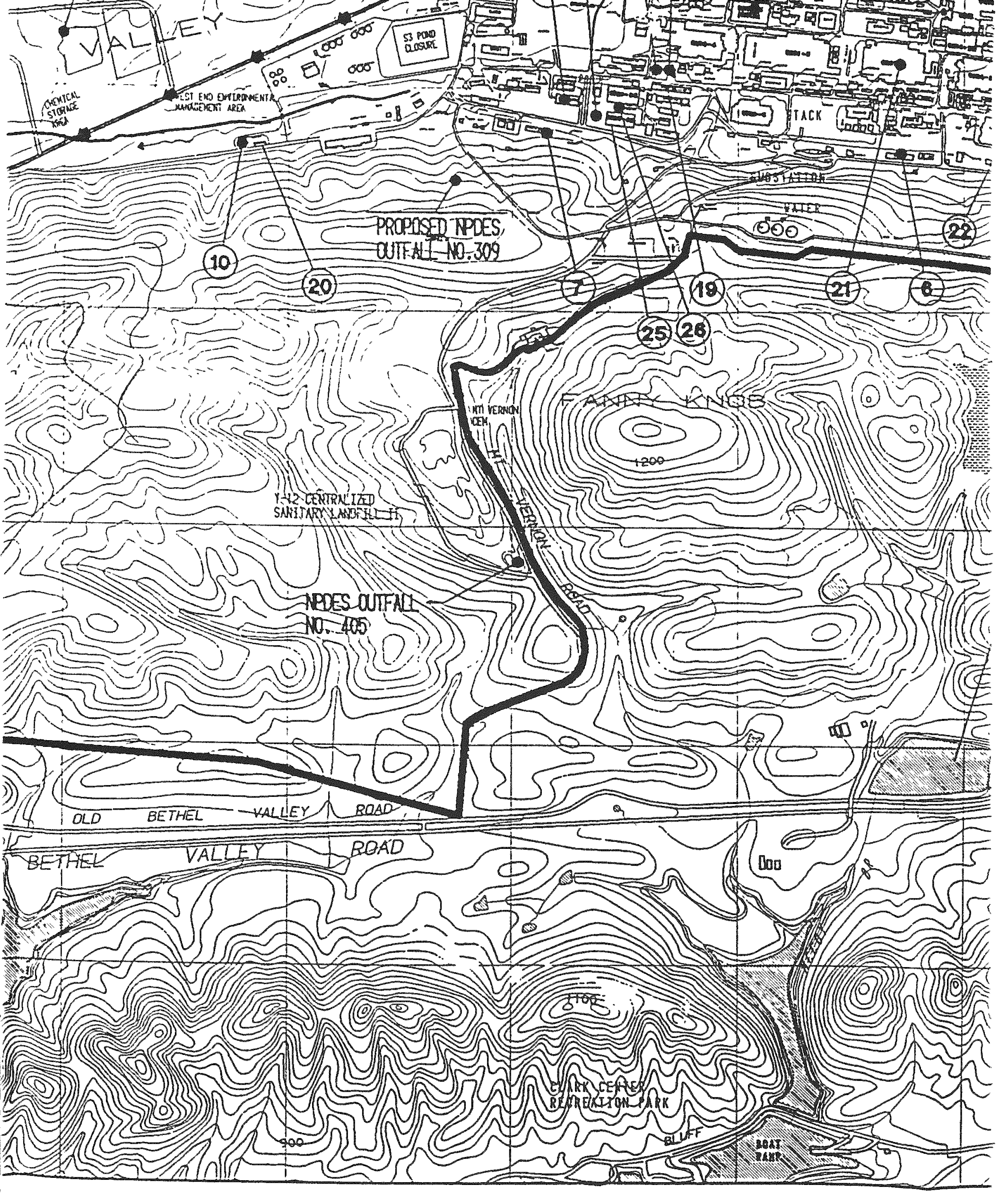


External Distribution:

Mr. Mack Bailey

Fire Department Chief

City of Oak Ridge

Post Office Box 1

Oak Ridge, Tennessee 37831

Mr. David Bolling

Anderson County Executive

100 North Main Street

Clinton, Tennessee 37716

Mr. Timothy Braaten

Chief of Police

City of Oak Ridge

Post Office Box 1

Oak Ridge, Tennessee 37831

Mr. Wayne Britt

University of Tennessee Lifestar

1924 Alcoa Highway, Box 103

Knoxville, Tennessee 37920

Mr. Jeff Broughton

City Manager

City of Oak Ridge

Post Office Box 1

Oak Ridge, Tennessee 37831

Mr. Arnold Clower

Roane County Sheriff

100 Race Street

Kingston, Tennessee 37763

Mr. Kenneth Fritts

Anderson County Local Emergency Planning Committee

Route 2, Box 980

Heiskell, Tennessee 37754

Mr. David L. Hatton

Chief, Volunteer Fire Department

Anderson County Marlow Unit

Route 8, Box 410

Clinton, Tennessee 37716

Mr. Virgil Hubbard

Chief, Karns Volunteer Fire Department

Post Office Box 7184

Knoxville, Tennessee 37921 
Mr. Larry Hutsell, Director

Regional Emergency Medical Services

Tennessee Department of Health

1522 Cherokee Trail

Post Office Box 59019

Knoxville, Tennessee 37950-9019

Mr. Phil Keith

Knox County Local Emergency Planning Committee

City-County Building

Knoxville, Tennessee 37901

Mr. George Matthews

Administrator

Methodist Medical Center of Oak Ridge

990 Oak Ridge Turnpike

Oak Ridge, Tennessee 37830

Mr. Robert McKamey

Anderson County Ambulance Service

103 South Charles Seiver Boulevard

Clinton, Tennessee 37716

Mr. Bowden Ladd

Roane County Ambulance Service

Route 8, Box 198

Harriman, Tennessee 37748

Mr. LeRoy Mitchell

Roane County Emergency Director

Post Office Box 43

Rockwood, Tennessee 37854

Mr. Russell Newman

Tennessee Emergency Management Agency

836 Louisville Road

Alcoa, Tennessee 37701

The Honorable James L. Session

Mayor of Oliver Springs

607 Easterbrook Avenue

Oliver Springs, Tennessee 37840

Mr. Charles Sitzlar

Tennessee Emergency Management Agency

836 Louisville Road

Alcoa, Tennessee 37701 
Ms. Lacy Suiter

Tennessee Emergency Management Agency

State Emergency Operations Center

3041 Sideo Drive

Nashville, Tennessee 37204-1502

Mr. Lloyd Terry

Loudon County Local Emergency Planning Committee

Post Office Box 312

Loudon, Tennessee 37774

Mr. Ken Yeager

Roane County Local Emergency Planning Committee

Post Office Box 43

Rockwood, Tennessee 37854 
Internal Distribution:

M. R. Anderson

D. M. Best

D. L. Bird

L. Boshears

S. A. Bowen

R. W. Boyd

J. T. Bryson

R. W. Burnett

L. C. Cappiello

J. A. Coffey

D. L. Danjels

C. D. Davis

D. E. Deel

J. C. Drewery

O. E. Duncan

M. S. Dunn

H. J. Foster

R. V. Fowler

J. R. Frost

M. A. Guinn

L. Y. Guerrero

C. C. Hill

W. Howard, Jr.

G. L. Humphrey

K. D. Hunt

P. L. Hyman

C. E. Irwin

M. E. Johnson

M. H. Johnson

R. M. Keyser/J. E. Powell

C. M. LaBorde/M. S. Burris

A. K. Ladd

A. K. Lee

L. G. Loden

M. E. Manning

J. C. Mathis

R. L. McDougal

C. Metz

C. O. Miller III

A. G. Mitchell

M. E. Mitchell/T. P. A. Perry

R. W. Mitchell

J. S. Parrott

R. D. Parsons

M. O. Phillips

J. J. Plante

P. D. Psihogios

L. L. Radcliffe/J. L. Sager, DOE-ORO
W. J. Redmond

G. A. Renfroe

T. Scott

R.W. Sellars

B. E. Skaggs

R. R. Smith

R. J. Spence/B. C. DeMonia, DOE-ORO

J. C. Stutts

E. J. Tobler

L. L. Triplett

E. Turnbill

J. L. Villarreal

T. R. Vincent

D. R. Walker

G. H. Winebarger/J. T. Foust

C. F. Wisener

W. B. Woods

R. C. Wright

$\mathrm{Y}-12$ Central Files

File - EMD - RC 



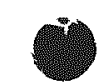

- 


\section{SECTION H \\ PERSONNEL TRAINING}

\section{H-1 OUTLINE OF TRAINING PROGRAM}

The information contained in this section of the permit application outlines the training programs for personnel at the Y-12 Plant who are directly involved with the operation of hazardous waste management units in accordance with the requirements of 40 CFR Parts 264 and 270, and Rules 1200-1-11-.07 and -.06 of the Rules Governing Hazardous Waste Management in Tennessee.

\section{H-1a Job Titles and Tasks}

Responsibility involving compliance with RCRA resides with the responsible department head and/or supervisor for each unit. The Staff Engineer for each unit provides technical support and project management related to the physical aspects and compliance requirements of the unit. Sampling, verification of waste streams, documentation, and quality control regarding storage and management procedures is the responsibility of the operating organizations of the Buildings 9206, 9212, and 9720-12 Container Storage Areas and the operating organization of the Cyanide Treatment Unit. Actual handling of wastes and movement of wastes into and out of the building is performed by trained operators working at the specific units. The job titles, tasks, and task descriptions for each position are presented in Appendix $\mathrm{H}-1$. The minimum information provided in the job descriptions are as follows:

- Position title,

- Basic function of position,

- Major environmental duties and responsibilities, and

- Formal education required.

\section{$\mathrm{H}-1 \mathrm{~b}$ Training Content. Frequency, and Techniques}

The workers receive documented performance-based training and job-specific training. Training techniques are patterned after the performance-based training and include, but are not limited to, classroom, on-the-job, and required reading materials.

Procedures exist which delineate training responsibilities and structures within the Y-12 Plant. All personnel who work at the units in this permit receive initial and annual refresher OSHA Hazard Communications Training, initial OSHA/SARA 40-hour or 24-hour training, 
8-hour OSHA/SARA supervisor training or 8-hour refresher OSHA/SARA training, annual respirator training, annual RCRA training, and biennial radiation protection and criticality safety training. The frequency of the course training is also presented in Appendix H-1. Specific modules used are listed in the following paragraph.

Basic Training: The basic training program includes, but is not limited to, the following subject areas:

- 24-Hour OSHA/SARA Training: All personnel working at the units in this application receive the 24-Hour Hazardous Waste Management Training and an annual 8-hour refresher as required by OSHA per SARA. Supervisors receive an additional 8 hours of training as required.

- Hazard Communications Training: All personnel receive the initial Hazard Communications training and annual refresher as required by OSHA. Specific modules listed below are included as part of this training as applicable.

- RCRA Annual Training: This module presents the basic requirements for compliance with RCRA and includes proper hazardous waste management and documentation. This module is updated annually as needed and presented to the applicable personnel. Personnel responsible for completing manifests receive an additional hour of training specifically addressing the proper completion of manifests for off-site shipment of hazardous wastes.

Specifically, the following subjects will be covered in the annual RCRA refresher training:

- Hazard Communication/Toxicology: This training program is designed to inform employees of the potential harmful effects of chemicals. The program examines the nature of toxic effects, the dose/response relationship, routes of entry of toxic substances, and various acute and chronic effects.

- Hazard Communication/Chemical Safety: Training will outline an overview of the health and safety hazards that chemicals pose and good chemical safety practices, thus motivating workers to take precautions to protect themselves. It describes the different forms of chemicals, routes of exposure, common signs and symptoms of 
exposure, and the effects of exposure. Materials described include carcinogens, corrosives, toxins, irritants, sensitizers, and chemicals that have target organ effects. The importance of using labels and material safety data sheets, as well as the measuring and monitoring of the job environment, will be detailed.

- Corrosives: This module presents the hazards that corrosives pose, describes the exposure symptoms, discusses containers and storage, outlines personal safety precautions, and explains what to do in the event of an emergency.

- Solvents: This module concentrates on the health and safety precautions when working with solvents.

- Poisons: This module discusses the different forms of poisons, safe handling procedures, and proper storage. It emphasizes personal protection as well as emergency methods and first aid. This module places emphasis on compressed gases because of their widespread use and the physical hazards that they pose.

- Gases: This module discusses proper moving and storing of gas cylinders, the effect of different gases on the body, personal protection, what to do in an emergency, and special instructions for emergency and rescue personnel.

- Oxidizers: This module addresses the proper safety and health measures when handling oxidizers.

- Explosives: This module stresses the importance of using the correct tools and equipment, maintaining a proper work environment, checking labels and material safety data sheets, and checking process sheets for all operations or processes which involve potential explosion hazards.

- Protective Clothing: In dealing with chemical hazards, the most important line of defense against personal contact and contamination is protective clothing. Training details the correct methods of selecting and wearing protective equipment including gloves, aprons, goggles, etc., as required.

- Respiratory Protection: In order to protect the respiratory tract against irritating and poisonous gases, fumes, smoke, and dusts, the worker must be knowledgeable 
in the proper use of the respirator. Information on the various types of respirators, the requirements to ensure a good fit, and emergency actions are presented in this module. Workers will also be trained on the specific respiratory hazards, requirements, and issue procedures for their specific job.

- Radiological Protection: Informs workers about the hazards associated with radiation exposure and presents methods of controlling dose levels to within acceptable limits. Training will be presented in two modules, "Basic Radiation Theory" and "Biological Effects of Ionizing Radiation" or an equivalent course.

- Criticality Safety: The concepts and required safety controls related to criticality safety are explained in this module.

Job Qualification: Currently, on-the-job training (OJT) of operators is conducted under the direct supervision of the operations supervisor. This training includes operational and job safety requirements. However, in order to improve, formalize, and document the required OJT, the job task analysis for each of these facilities has been completed. Based on this job task analysis and specific safety requirements for each facility, lesson plans for OJT will be completed and will be performed by OJT instructors who have successfully completed the Supervisors On-The-Job Training course. At the completion of training, a formal test is given. The test may be written and/or oral, depending upon the nature of work being conducted at the facility. In addition to the written and/or oral examination, the operator will be required to demonstrate his proficiency in the required tasks. Failure of the test requires the technician/laborer to undergo further training. Though the lesson plans will be specifically directed at the proper operation of the facilities, general topics to be included as applicable are: (1) conducting routine checks and inspections, (2) job-specific personal protective equipment training, and (3) maintaining records and data. OJT refresher training will be provided every two years.

Emergency Preparedness: The training program is designed to ensure that personnel not only handle hazardous wastes in a safe manner, but also properly respond to emergency situations. The program trains hazardous waste handling/management personnel to maintain compliance under both normal operating conditions and emergency conditions.

Training elements addressing non-routine and emergency situations (unscheduled shutdowns and startups related to storms, power outages, fires, explosions, spills) as applicable include: 
1. Contingency Plan requirements and implementation,

2. Procedures for locating, using, inspecting, repairing, and replacing facility emergency and monitoring equipment, including personal safety, fire control, and spill control equipment and alarm and communication systems,

3. Response to fires or explosions,

4. Response to incidents and procedures for containing, controlling, and mitigating spills, and any surface or groundwater contamination,

5. Shutdown of operations, power failure procedures and any other emergency operating procedures, and

6. Procedures for evacuation of nearby areas.

In addition to the hazardous waste management personnel, a plant emergency squad is on duty for response to all fires and other general plant emergencies. This emergency squad is trained with classroom training methods and fire drills. The classroom training is required for introductory training and as an annual review for each member of the squad.

Annual Training Records Review: The Facility Supervisor assigned to the units performs a review of the training records for the division at least annually.

\section{H-1c Training Director}

The personnel training program is directed by a Divisional Training Manager who is familiar with plant operations, facility design, and operating procedures. This manager is required to have a minimum of a bachelors degree or equivalent education and/or experience and process knowledge, and demonstrated knowledge of instructional system design and technology. The Training Coordinators and the OJT Trainers who perform the training matrix to the Training Manager. The qualifications required for these positions are included in the job descriptions found in Appendix $\mathrm{H}-1$.

\section{H-1d Relevance of Training to Job Position}

The training program is designed in some areas to provide training to personnel at levels that are relevant to their positions within the plant. Operators are more specifically trained 
to maintain proper and safe operating procedures and to respond effectively in the event of a spill or other emergency. The completed job task analysis for each of these four units will be utilized to update and improve the existing training as applicable in order to continue to make the training more relevant to the specific job position being trained.

\section{H-2 IMPLEMENTATION AND DOCUMENTATION OF TRAINING PROGRAM}

H-2a Implementation

All personnel must complete this training within six months from their date of assignment to a hazardous waste management job. No employee assigned to perform a hazardous waste management job works unsupervised prior to completion of the training program.

\section{$\mathrm{H}-2 \mathrm{~b}$ Recordkeeping}

Please see Section J, Recordkeeping, for information. 


\section{SECTION I}

\section{CLOSURE PLAN, POST CLOSURE PLAN, AND FINANCIAL REQUIREMENTS}

\section{I-1 CLOSURE PLANS}

This closure plan has been prepared for the Buildings 9206, 9212 and 9720-12 Container Storage Areas, and the Cyanide Treatment Unit at the Y-12 Plant. These units will be considered active units and operated in compliance with all applicable requirements for active units (including inspections, fire prevention, etc.) until closure activities are initiated. Complete facility descriptions are provided in Section B, Facility Description.

The Oak Ridge Y-12 Plant is located in Anderson County and is co-operated and managed by Martin Marietta Energy Systems Inc., personnel for the DOE. The EPA identification number for the Y-12 Plant is TN3 89-009-0001.

If changes occur in the operating plans or unit design that may affect the closure plan, it will be amended. Amendments to the closure plan may also be necessary if: (1) new technologies are developed, (2) changes occur in operating requirements or contingencies, and (3) changes occur in the land-use patterns around the site.

\section{I-1a Closure Performance Standard}

This closure plan is designed to ensure that, after closure, the unit will not require further maintenance and controls; to minimize or eliminate threats to human health or the environment; and to avoid the escape of hazardous wastes, hazardous waste constituents, leachate, contaminated rainfall, or waste decomposition products to ground or surface waters, or to the atmosphere.

This standard will be accomplished through the removal of all RCRA hazardous wastes stored in containers at the units. These wastes will be transferred to an appropriately permitted facility for storage, treatment, or disposal. In addition, to minimize residual contamination on-site, the storage or treatment building area and appurtenances will be cleaned until the facility has been satisfactorily decontaminated.

Efforts to be made to satisfy closure requirements are presented in the following sections.

\section{I-1b Partial Closure and Final Closure Activities}

Partial closure for the units in this application is not anticipated. If it becomes necessary to 
partially close any of the units described in this permit application, the procedures described in Section l-1e(1), Closure Procedures, will be followed for the type of unit being closed.

Final closure of the units will consist of the removal of all hazardous wastes and hazardous waste residues remaining at the unit and the decontamination or disposal of the containment structure components and auxiliary equipment. All hazardous wastes and residues will be containerized and transported to an approved RCRA permitted facility for storage or treatment. Closure procedures are described in Section I-1e, Closure procedures.

\section{I-1c Maximum Waste Inventory}

The following table represents the maximum waste inventory that will be in storage at the units (Refer to Table D-1).

Unit ID

\begin{tabular}{lc}
\hline 9206 & 3,975 \\
9212 & 3,814 \\
$9720-12$ & 32,500 \\
Cyanide Treatment Unit & 2,200 \\
\hline
\end{tabular}

All hazardous wastes remaining in these units at the time of closure will be transferred to a permitted facility for storage or treatment. The procedures for removing, transporting, and/or storing the remaining hazardous waste and decontamination debris from the units are described in Section I-1e(1), Closure Procedures and Section I-1b, Partial Closure Procedures.

\section{I-1d Schedule for Closure}

The proposed schedule for final closure for Buildings 9206, 9212 and 9720-12 Container Storage Areas and the Cyanide Treatment Unit is included as Table I-1. Because the units in this permit application are container storage areas associated with enriched uranium production, the same schedule can be followed for each individual unit. The units are expected to be closed in the year 2025 . 


\section{I-1d(1) Time Allowed For Closure}

All hazardous wastes will be treated, removed off-site, or disposed of on-site from the units within 90 days from receipt of the final volume of hazardous waste. Closure activities will be completed within 180 days from the closure plan approved by the State. The actual times for each step of the closure activities are shown in Table I-1.

\section{I-1d(1)(a) Extensions for Closure Time}

It is not anticipated that an extension of time for closure activities will be required. However, if closure cannot be completed within the specified time, a request for an extension of closure time will be submitted to the Commissioner in accordance with Tennessee Rule 1200-1-11-.06(7)(d).

\section{I-1e Closure Procedures}

Before closure activities begin, the units will be surveyed by the Y-12 Health Physics Organization personnel and a safety plan will be prepared based on the site conditions. The plan will identify radiological and chemical hazards as well as controls to reduce worker risk. Additional activities for closure follow.

\section{I-1e(1) Inventory Removal, Disposal, and Decontamination of Equipment}

Closure activities for all the units in this permit application will be performed in a similar manner.

\section{Step 1: Removal of Waste Inventory}

All containers of hazardous waste will be transferred to an approved facility for storage or treatment. Equipment to be used will be, but is not limited to, forklift truck, hand pallet jack, and/or hand dolly.

\section{Step 2: Decontamination of Building, Equipment, and Structures}

The walls, floors, and miscellaneous fixtures (i.e., shelves, windows, etc.) in the building will be cleaned and rinsed with water and detergent, if needed. All wash and rinse waters will be collected, drummed, and stored at an approved on-site storage facility pending the analysis from samples taken from the water. Based on the analytical results, the drummed water will be disposed of in an appropriate manner. 
TABLE I-1. CLOSURE SCHEDULE FOR THE

PRODUCTION ASSOCIATED UNITS

\section{Action}

Expected *

Completion

- Notify Tennessee Department of Health and

-180 days

Environment of intent to initiate

- Receipt of final volume of wastes; initiate closure 0

- Remove inventory, load and transfer 90

- Decontaminate building, equipment, and structures 110

- Decontaminate equipment 115

$\begin{array}{ll}\text { - Sample building surfaces } & 120\end{array}$

$\begin{array}{ll}\text { - Analyze samples and results } & 150\end{array}$

- Prepare documentation for certification by an 175 independent Professional Engineer

- Closure Certification by DOE

or

- Repeat building decontamination, surface sampling, and sample analysis prior to decontamination of equipment

- Independent Professional Engineer and Department of Energy certify closure

* Number of days following initiation of closure.

** If decontamination must be repeated, extension of the closure schedule beyond the maximum of 180 days will be requested. 
Step 3: Decontamination of Equipment

This step will involve the decontamination or washing of residuals that may adhere to the equipment used in steps 1 and 2. The wash and rinse solutions will be disposed of in the same manner as the wash water generated in step 2, Decontamination of Building.

\section{Step 4: Verification of Decontamination}

Rinse water samples will be analyzed for the hazardous constituents formerly stored in the container storage and treatment areas as an indicator of decontamination verification. Contamination will be considered complete if the concentration of these constituents in the water are less than the RCRA regulated levels. The sample will be analyzed by EPA method ("Test Methods for Evaluating Solid Waste", SW-846). Sampling and analytical quality assurance/quality control will be conducted as specified in SW-846 (see Table I-1 for schedule). Further water and surfactant/water rinses will be used if decontamination of an item is not complete. These rinses will be repeated until decontamination criteria are met.

\section{Step 5: Additional Decontamination}

If residual contamination exists after a third washing, the areas will be sandblasted until contamination is no longer exhibited. Spent sand will be collected and stored pending selection of an approved disposal method.

\section{Step 6: Certification}

Documentation for certification by an independent Professional Engineer will be prepared. Final certification of closure by DOE and MMES will be performed.

\section{I-1e(2) Closure of Disposal Units}

Not applicable. Requirements of this section do not apply to the container storage areas or the treatment unit in this permit application.

\section{I-1e(3) Closure of Containers}

The closure procedures described in Section I-1e, Closure Procedures, will be followed for the closure of the container storage units containing the maximum waste inventory specified in I-1c. 


\section{I-1e(4) Closure of Tanks}

Not applicable. Requirements of this section do not apply to the container storage areas or the treatment unit in this permit application.

\section{I-1e(5) Closure of Waste Piles}

Not applicable. Requirements of this section do not apply to the container storage areas or the treatment unit in this permit application.

\section{I-1e(6) Closure of Surface Impoundments}

Not applicable. Requirements of this section do not apply to the container storage areas or the treatment unit in this permit application.

\section{I-1e(7) Closure of Incinerators}

Not applicable. Requirements of this section do not apply to the container storage areas or the treatment unit in this permit application.

\section{I-1e(8) Closure of Landfills}

Not applicable. Requirements of this section do not apply to the container storage areas or the treatment unit in this permit application.

\section{1-1e(9) Closure of Land Treatment}

Not applicable. Requirements of this section do not apply to the container storage areas or the treatment unit in this permit application.

I-1e(10) Closure of Miscellaneous Units

Not applicable. Requirements of this section do not apply to the container storage areas or the treatment unit in this permit application.

\section{I-2 POST-CLOSURE PLAN}

Hazardous waste or hazardous waste residues will not remain at the units after closure; therefore, this section is not required.

\section{I-2a Inspection Plan}

Hazardous waste or hazardous waste residues will not remain at the units after closure; therefore, this section is not required. 


\section{I-2b Monitoring Plan}

Hazardous waste or hazardous waste residues will not remain at the units after closure; therefore, this section is not required.

\section{I-2c Maintenance Plan}

Hazardous waste or hazardous waste residues will not remain at the units after closure; therefore, this section is not required.

\section{I-2d Land Treatment}

Hazardous waste or hazardous waste residues will not remain at the units after closure; therefore, this section is not required.

\section{I-2e Post-Closure Care for Miscellaneous Units}

Hazardous waste or hazardous waste residues will not remain at the units after closure; therefore, this section is not required.

\section{I-2f Post-Closure Security}

Hazardous waste or hazardous waste residues will not remain at the units after closure; therefore, this section is not required.

\section{I-2g Post-Closure Contact}

Hazardous waste or hazardous waste residues will not remain at the units after closure; therefore, this section is not required.

\section{I-3 CERTIFICATION AND NOTICES REQUIRED FOR CLOSURES}

\section{I-3a Certification of Closure}

Within 60 days of completing final closure of the units, DOE will submit, in writing, a closure certification to the Commissioner. The certification will verify that the units were closed in accordance with the specifications of the approved closure plan. The certification will be signed by DOE and an independent registered professional engineer and submitted by registered mail.

\section{I-3b Survey Plat}

Not applicable. A survey plat is not required for the clean closure of a container storage or treatment unit. 
I-3c Notice to Local Land Authority

Not applicable. This section is not required for the clean closure of a container storage or treatment unit.

\section{I-3d Post-Closure Certification}

Not applicable. This section is not required for the clean closure of a container storage or treatment unit.

\section{I-3e Notice in Deed to Property}

Not applicable. This section is not required for the clean closure of a container storage or treatment unit.

\section{I-4 CLOSURE COST ESTIMATE}

Under 40 CFR Part 264.140(c), federal facilities are exempt from the requirements of this section.

\section{I-5 FINANCLAL ASSURANCE MECHANISM FOR CLOSURE}

Under 40 CFR Part 264.140(c), federal facilities are exempt from the requirements of this section.

\section{I-6 POST-CLOSURE COST ESTIMATE}

Under 40 CFR Part 264.140(c), federal facilities are exempt from the requirements of this section.

\section{I-7 FINANCIAL ASSURANCE MECHANISM FOR POST-CLOSURE}

Under 40 CFR Part 264.140(c), federal facilities are exempt from the requirements of this section.

\section{I-8 LIABILITY REQUIREMENTS}

Under 40 CFR Part 264.140(c), federal facilities are exempt from the requirements of this section.

\section{I-9 STATE FINANCIAL MECHANISM}

Under 40 CFR Part 264.140(c), federal facilities are exempt from the requirements of this section. 


\section{SECTION J}

RECORDKEEPING

This section of the application outlines the recordkeeping and reporting requirements for hazardous waste management units as required by 40 CFR Part 264 and Rule 1200-1-11-.06 of the Rules Governing Hazardous Waste Management in Tennessee.

\section{J-1 MANIFEST REQUIREMENTS}

Buildings 9206, 9212, and 9720-12 Container Storage Areas do not receive hazardous wastes from off-site; however, the Cyanide Treatment Unit accepts wastes from off-site on special occasions.

Procedures for accepting waste from off-site at the Cyanide Treatment Unit are described in Section C-2e. Wastes will not be accepted for treatment from off-site without a hazardous waste manifest, or without an accompanying shipping paper, unless the waste is excluded from the manifest requirement by 40 CFR Part 261.5. Unmanifested Waste Reports will be prepared and submitted, as necessary and as required by 40 CFR Part 264.76 .

\section{J-2 OPERATING RECORD}

Records and results of waste analyses, as required in 40 CFR Part 264.73(b)(3) and Tennessee Rules 1200-1-11-.02 and .06(5)(d)2(iii), are recorded and maintained in the operating files and databases of the operating organizations. The management, including storage and/or treatment, of hazardous wastes is tracked at all times.

For nonroutine wastes, the Y-12 Plant uses the "Request for Transfer, Storage or Disposal of Radioactive, Hazardous and Special Wastes" form (UCN-2109), which is located in Appendix C-1, for identification of waste materials. For routine wastes, the Y-12 Plant uses a "Blanket Request" process or "Stream Identification (SID) Number" process which assigns a specific waste stream a number to allow tracking of the waste. Upon generation af a routine or nonroutine waste, log sheets, completed forms, and generation records are provided by the generator, including the description and quantity of waste materials. These forms are assigned a unique number to facilitate entry into the waste tracking systems used by the Waste Management organization. The completed forms are reviewed by a technician or engineer from Waste Management organization to determine the appropriate storage, treatment, or disposal method which is recorded on the form and entered into the data base as applicable. After transporting the waste to the appropriate on-site storage or treatment 
unit or off-site disposal facility, the forms are signed and maintained by Waste Management organization personnel. Finally, operating logs are maintained which include the current quantity and type of wastes located at each facility.

The Y-12 Plant Waste Analysis Plan, discussed in Section C, defines the information required to safely store wastes in these units in accordance with RCRA regulations.

An incident requiring implementation of the Contingency Plan would be reported per Section G. A detailed, written report would be submitted by the Y-12 Plant Environmental Management Department to the TDEC within 15 days of the incident, and a file copy would be maintained by the Environmental Management Department. The report would include:

1. name, address, and telephone number of the owner or operator;

2. name, address, and telephone number of a contact at the unit;

3. date, time, and type of incident (e.g., fire, explosion);

4. name and quantity of material(s) involved;

5. extent of injuries, if any;

6. assessment of actual or potential hazards to public health or environment, if applicable; and

7. estimated quantity and disposition of recovered material that resulted from the incident.

Records of inspections for the units in this permit application are maintained by the appropriate Production Department. These records will be retained by the Production Department until three years after the certified closure of the unit. Inspection logs are completed per Section F, Procedures to Prevent Hazards. Copies of example inspection log sheets are provided in Appendix F-2. Groundwater monitoring data is not required for these facilities (Section E).

The DOE is the owner of the Y-12 Plant. The units addressed in this application receive wastes from the Y-12 Plant only, except for the Cyanide Treatment Unit which, on special occasions, may accept wastes from off-site. Off-site generators using the Cyanide Treatment Unit will be notified of the status of the Y-12 Plant RCRA permits.

The closure and postclosure cost estimates are not required for federal facilities as indicated in Section I, Closure Plans. 
The units addressed in this application are not surface impoundments, waste piles, land treatment units, or landfills. Therefore, no Land Disposal Restricted Certification Program is required. In addition, the requirements of groundwater data recordkeeping are not required.

The training records for personnel in the operating organizations are maintained by the organization training department. The training coordinator assigned to a designated operating or engineering department maintains these records for that specific department. Training information is discussed in Section $\mathrm{H}$.

Preparation of the annual and biennial reports on the hazardous waste activities at the Y-12 Plant is coordinated and maintained by the Environmental Management Department with data supplied by the Waste Management organization and waste generating divisions. These reports address the amount of waste generated, the amount of waste shipped off-site, the amount received, and the amount of waste currently on site.

As part of the annual report on the hazardous waste activities at the $Y-12$ Plant, wastestream specific waste minimization information is submitted to the TDEC for the Y-12 Plant. This annual report certification is prepared and maintained on file by the Environmental Management Department. Additionally, the biennial Waste Minimization Report is submitted to the EPA which contains similar information. The Y-12 Waste Minimization Program is designed to reduce the volume and toxicity of hazardous wastes generated at the $\mathrm{Y}-12$ Plant and provides information on the methods of reducing waste to minimize the threat to human health and the environment.

The operating records and reports are prepared, maintained, and available for inspection. Training records on current personnel are kept until closure of the hazardous waste management units. The training records of former employees are maintained for a minimum of 3 years from the date the employee last worked at the Y-12 Plant. Personnel training records accompany the employee during any transfer within the company. 


\section{SECTION K OTHER FEDERAL LAWS}

The Y-12 Plant has reviewed and considers to be in compliance with the following Federal Laws:

- Fish and Wildlife Coordination Act of 1934

- National Historic Preservation Act of 1966

- Wild and Scenic Rivers Act of 1968

- Coastal Zone Management Act of 1972

- Endangered Species Act of 1973

- Occupational Safety and Health Act of 1970

- National Environmental Policy Act, January 1, 1970

- Federal Water Pollution Control Act of 1977

- Clean Water Act

- National Emission Standards for Hazardous Air Pollutants, and

- Toxic Substances Control Act

- Clean Air Act.

Information will be provided by the Y-12 Plant personnel at the request of the TDEC staff. 


\section{SECTION L \\ ORGANIC AIR EMISSIONS}

Organic air emissions monitoring is not required for Buildings 9206, 9212, 9720-12 Container

Storage Areas, and the Cyanide Treatment Unit as per the requirements of 40 CFR Part 264, Subparts AA and BB. 


\section{SECTION M \\ SOLID WASTE MANAGEMENT UNITS}

Based on information from the State, material on solid waste management units at the Oak Ridge Y-12 Plant is not required for individual Part B permit applications because the entire ORR is covered by the ORNL Hazardous and Solid Waste Amendments Permit (HSWA TN001) for Building 7652 (a hazardous waste storage facility). The HSWA Permit was issued on September 26, 1986. 


\section{SECTION N \\ CERTIFICATION}

I certify under penalty of law that this document and all attachments were prepared under my direction and supervision in accordance with a system designed to ensure that qualified personnel properly gather and evaluate the information submitted. Based on my inquiry of the person or persons who manage the system and of those persons directly responsible for gathering the information, the information submitted is to the best of my knowledge and belief, true, accurate, and complete. I am aware that there are significant penalties for submitting false information, including the possibility of fine and imprisonment for knowing violations.

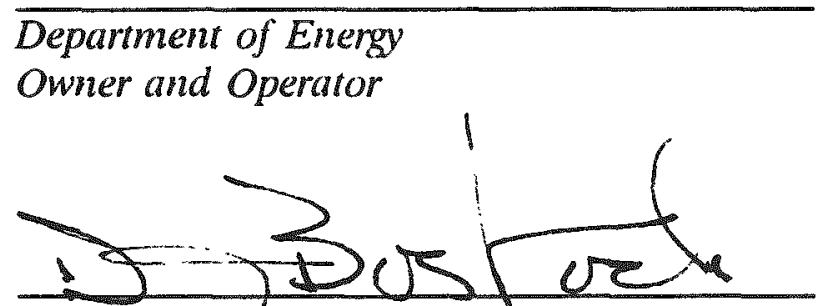

Martin Marietta Energy Systems. Inc. Co-Operator

\section{Date Signed}

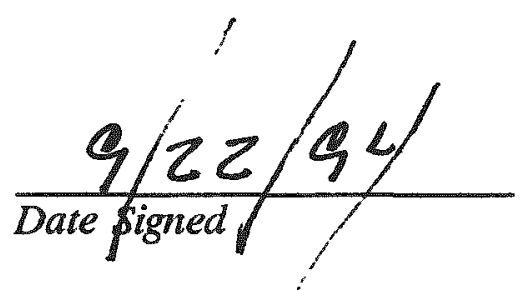

The Department of Energy and its operating contractor, Martin Marietta Energy Systems, Inc., have jointly signed this application as the operator of the permitted facility. The Department has determined that dual signatures best reflect the actual apportionment of responsibility under which the Deparment's RCRA responsibilities are for policy, programmatic, funding and scheduling decisions, as well as general oversight, and the contractor's $R C R A$ responsibilities are for day-to-day operations, including but not limited to, recordkeeping, reporting, and contingency planning. For purposes of the certification required by 40 CFR Section $270.11(d)$ and Tennessee Rule 1200-1-11-.07(2)(a)10, the Department's and Martin Marietta Energy Systems, Inc.'s, representatives certify, to the best of their knowledge and belief, the truth, accuracy and completeness of the application for their respective areas of responsibility. 
APPENDIX B-1

MAPS 


\section{OAK}

F

8

号

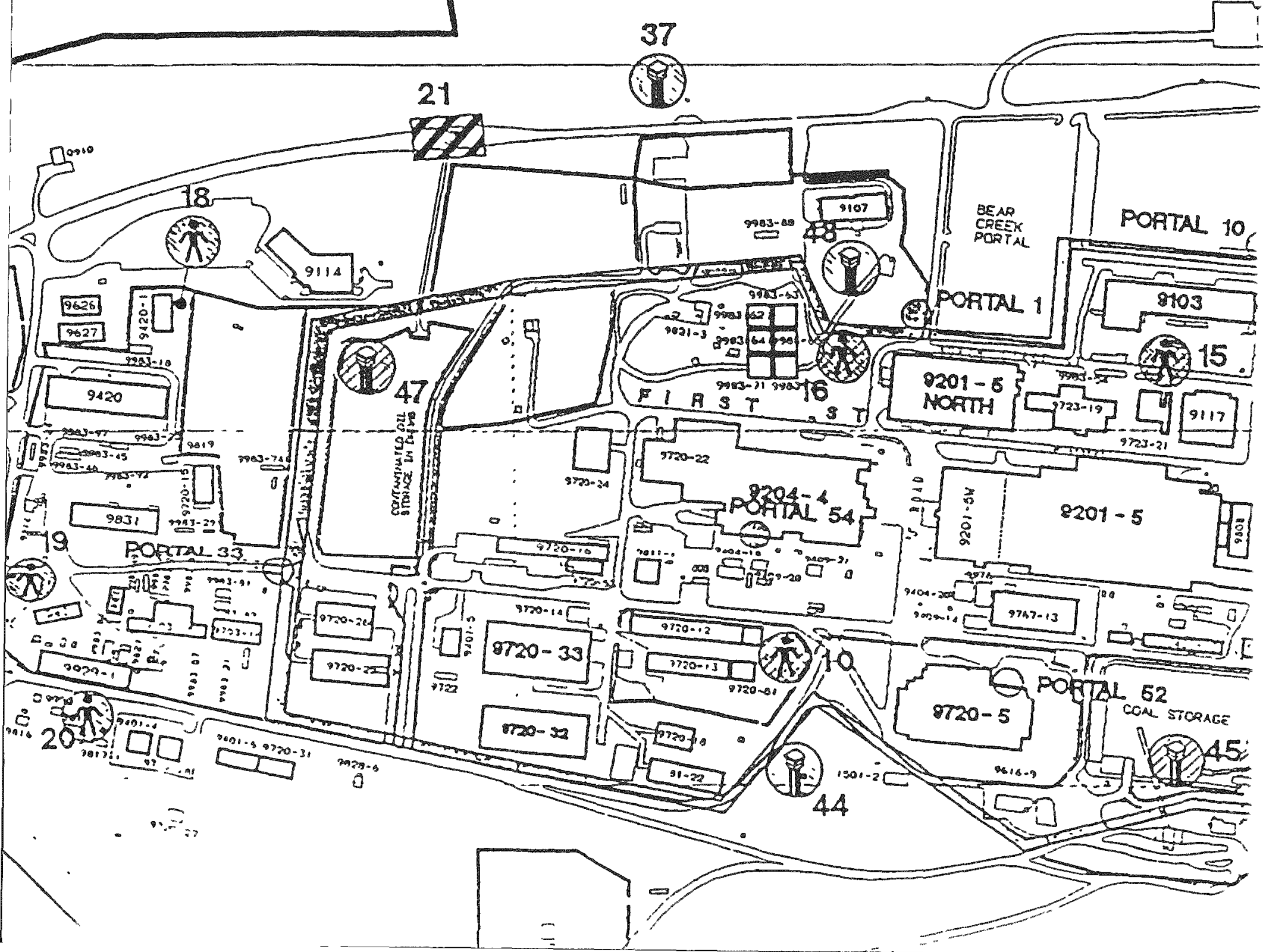




\section{RIDنEE}
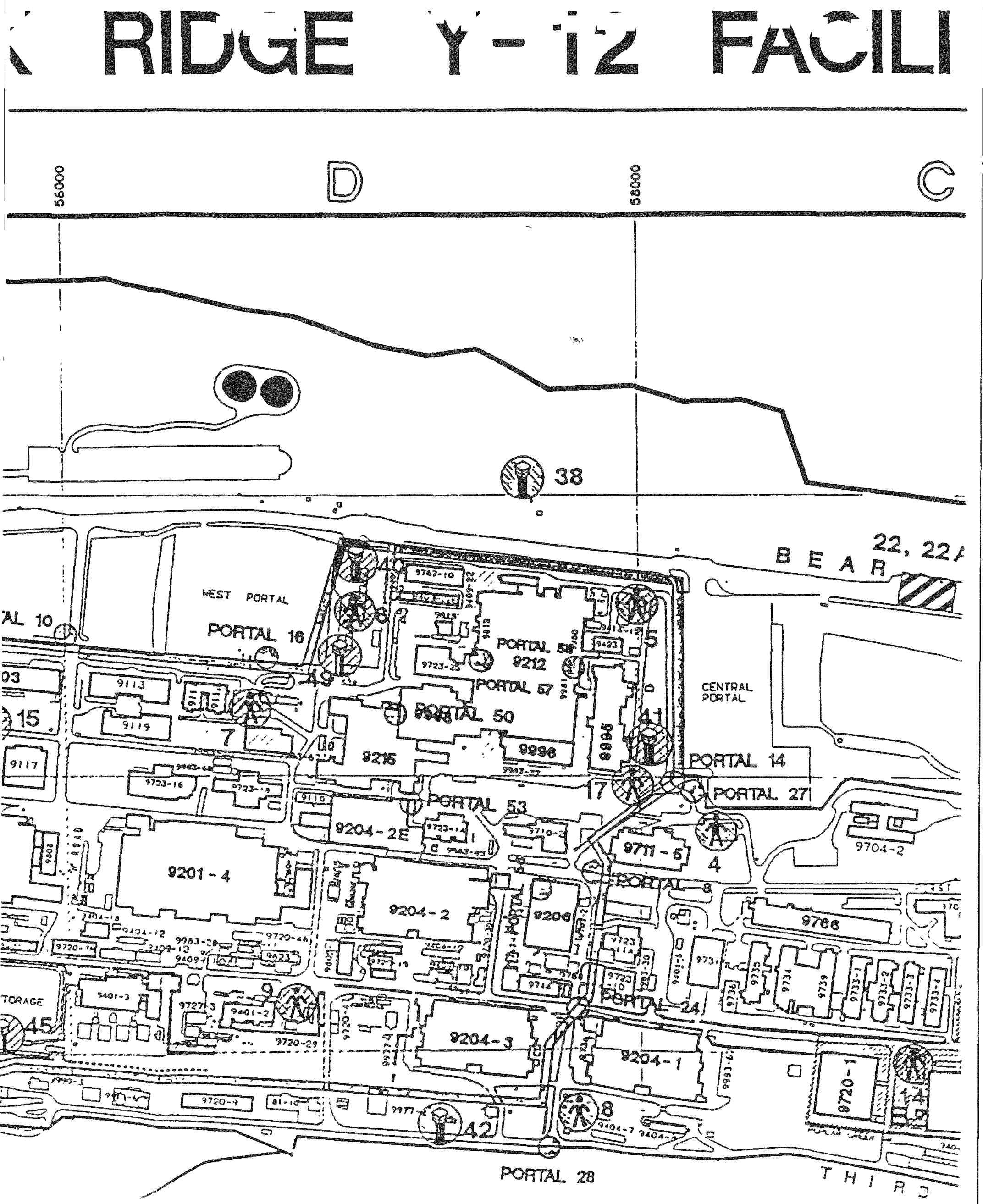


\section{ClLITIES MAP}
C
ริำ
圆

A $22,22 \mathrm{~A}, 22 \mathrm{~B}$

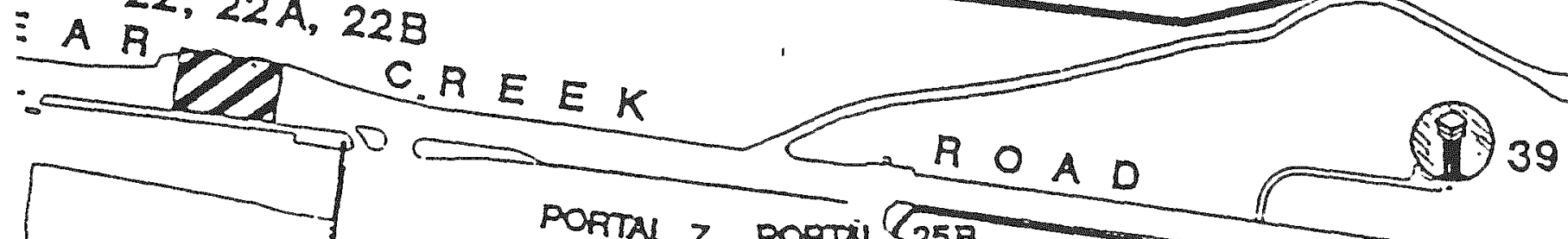

POATAL 7 POFTRI 258

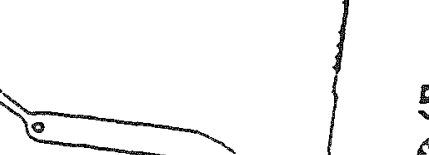

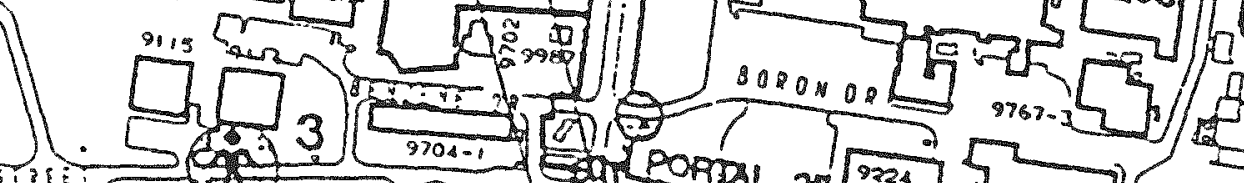

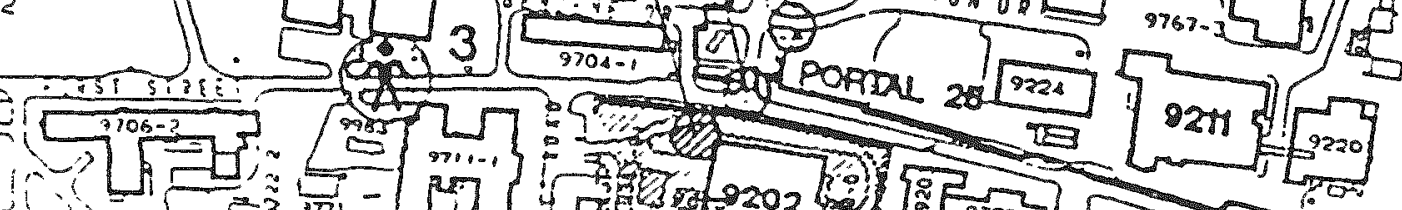

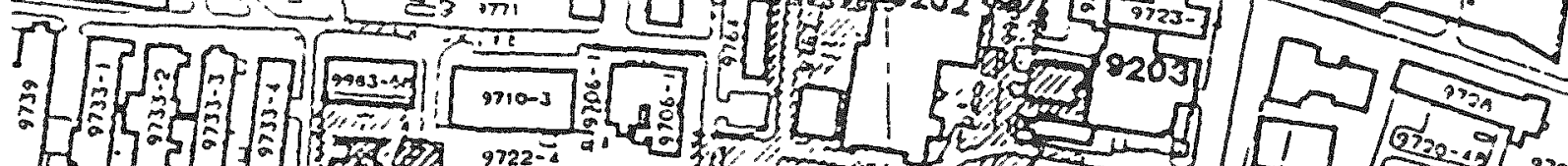

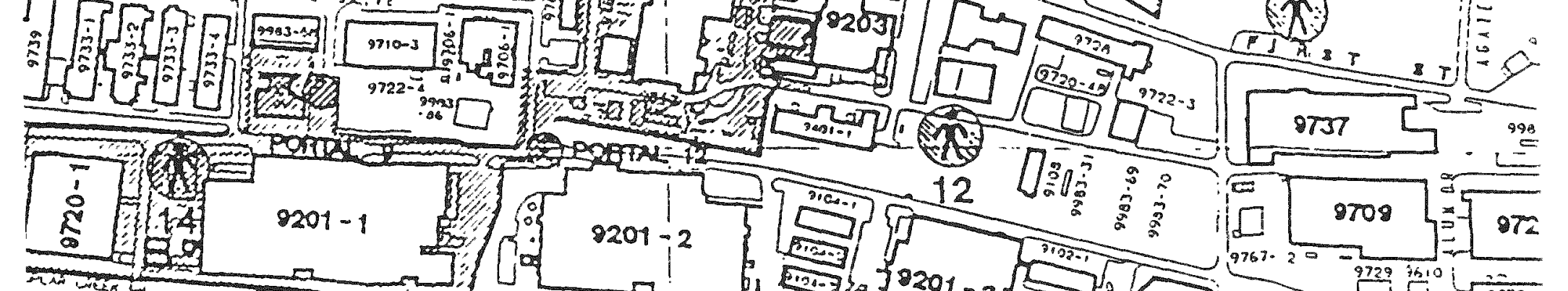

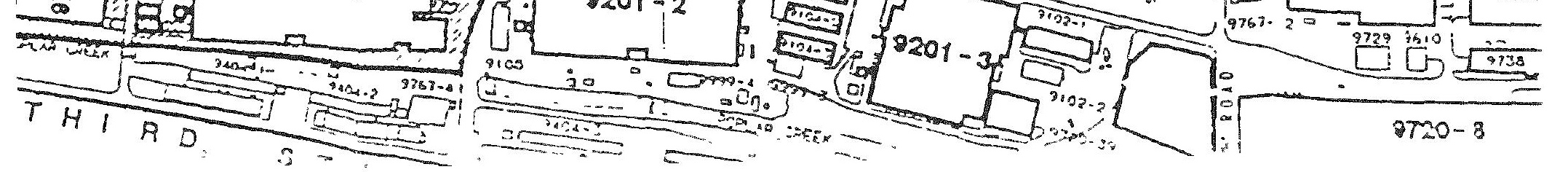




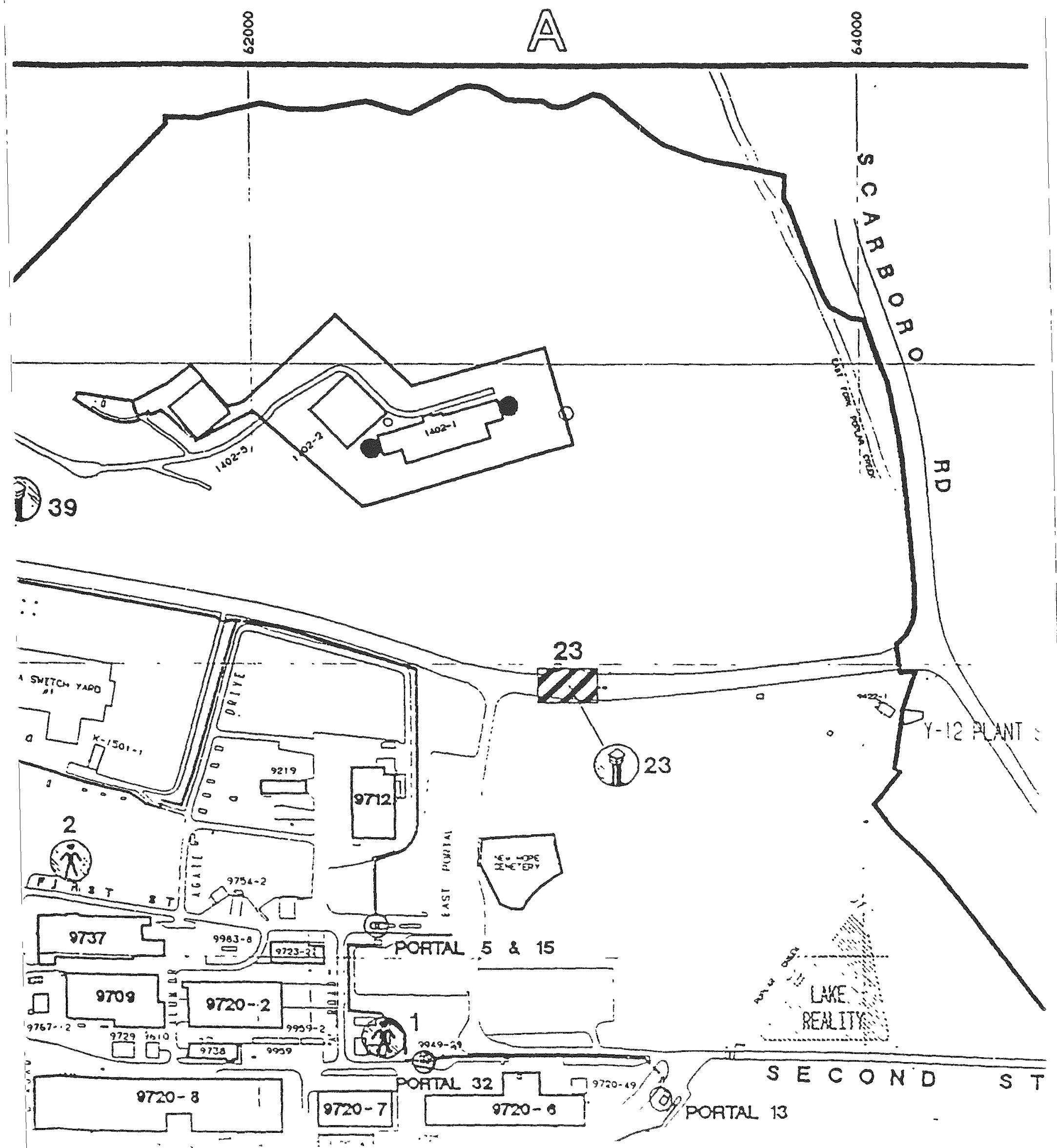




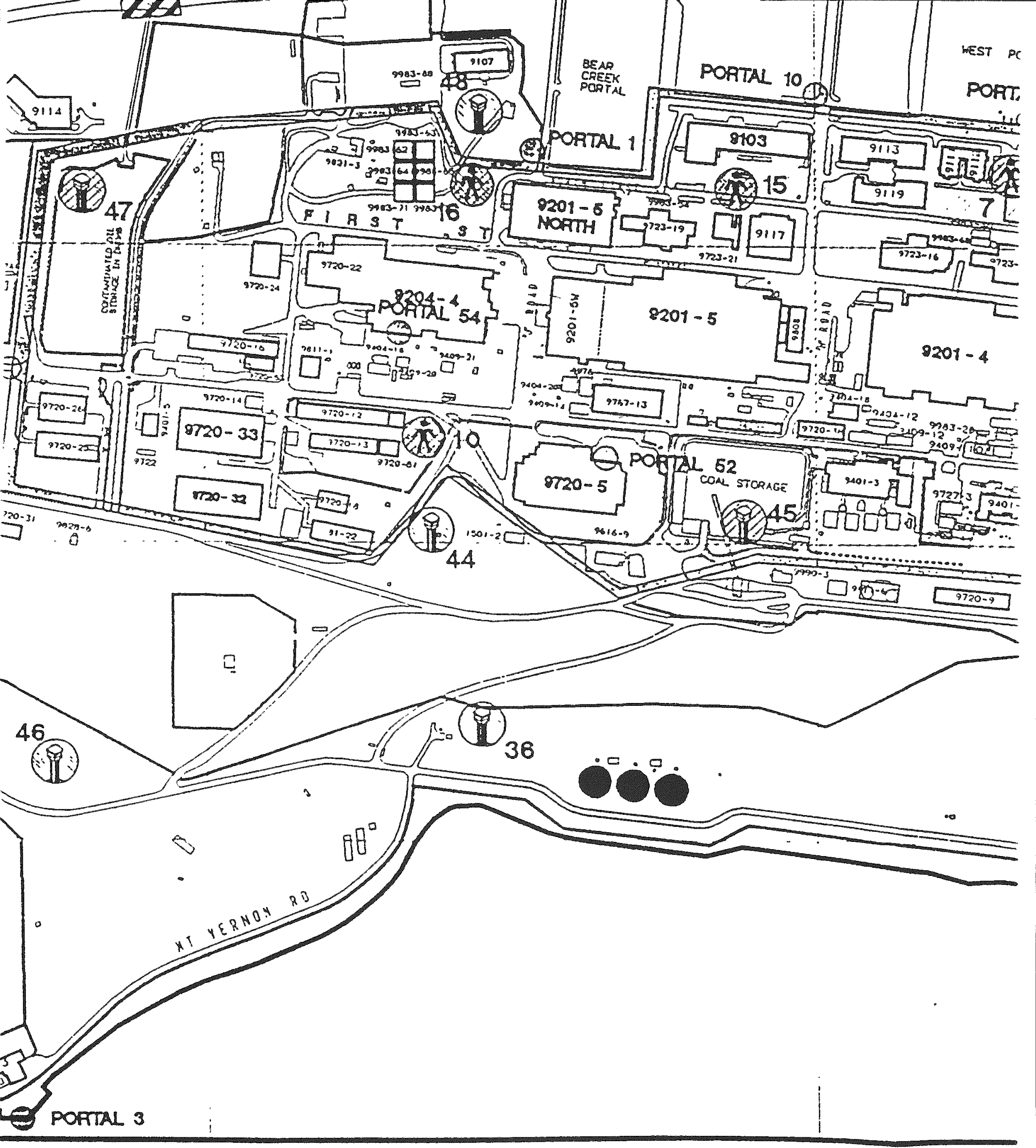




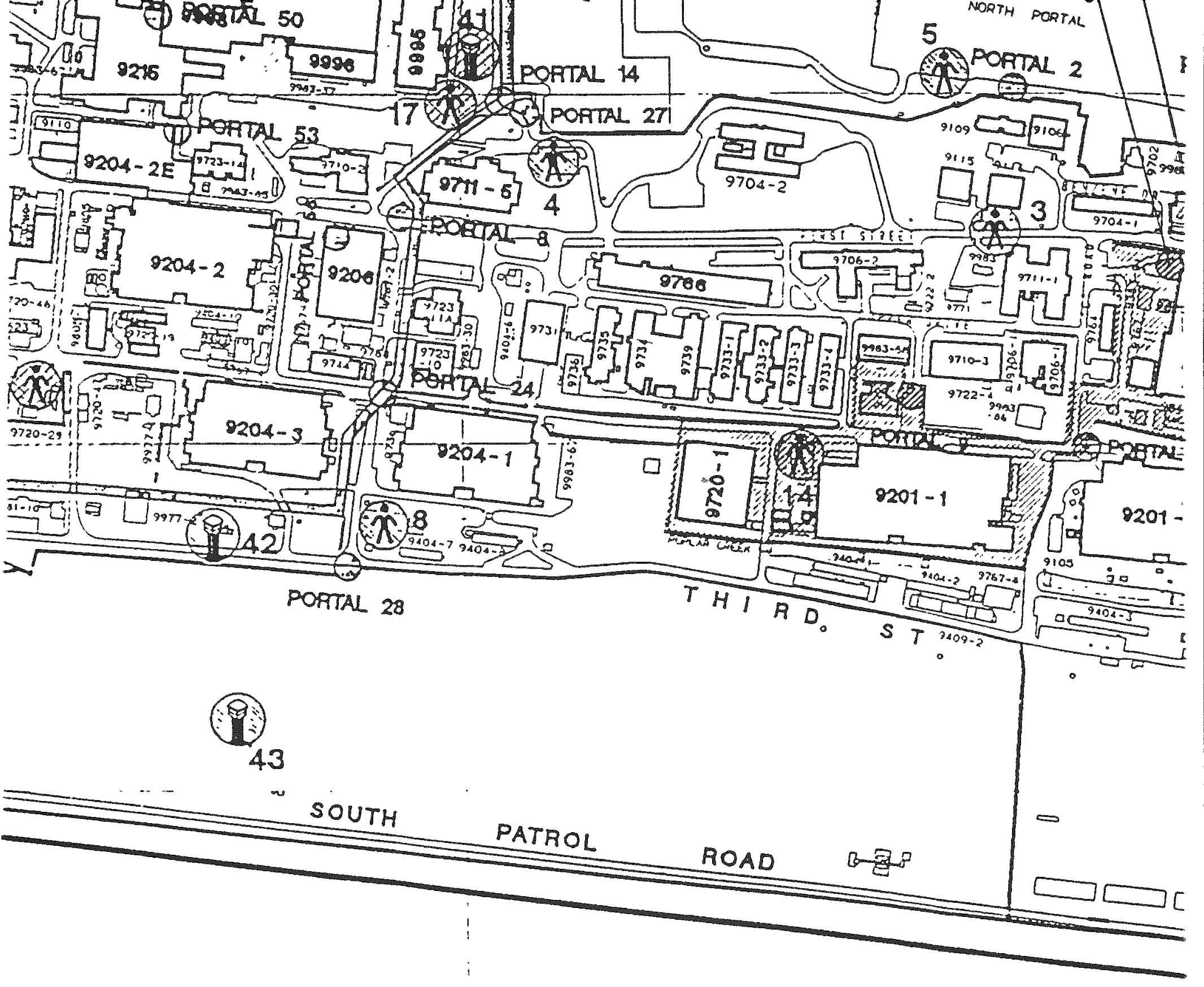




\section{OAK RIDGE Y-12 PLANT}

WASTE UNIT

IDENTIFICATION KEY

APPLICATION EPA

LINE PROCESS COOE DESCRIPTION

$1 \ldots \ldots$ TOA ........ CYANIDE TREATMENT UNIT

SOI

$2 \ldots \ldots . \ldots$ TO2 ....... KERR HOLLOW OUARRY TREATMENT UNIT

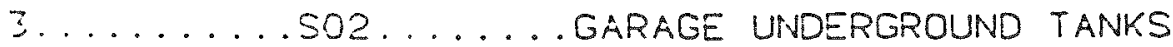

........ . . . . . WALK-IN PITS

$5 \ldots \ldots \ldots$. . . . . . INTERIM DRUM YARD

$6 \ldots \ldots . \ldots$ SO $\ldots . . .$. BUILDING 9720-9 STORAGE UNIT

$7 \ldots \ldots . . .501 \ldots . .$. RCRA \& MIXED WASTE STORAGE \&

STAGING BUILDING 9720-31

$8 \ldots \ldots . \ldots$. . . . . BUILDING $9811-1$ RCRA

TANK STORAGE UNIT

9............... BUILDING $9811-1$ RCRA

CONTAINER STORAGE UNIT

$10 \ldots \ldots . \ldots$ SO $\ldots . \ldots$ WASTE OIL/SOLVENT STORAGE UNIT SOI

$11 \ldots . . . . .5 O 2 \ldots . . . .4 I O$. ORGANIC SOLVENT STOR. UNIT SOI

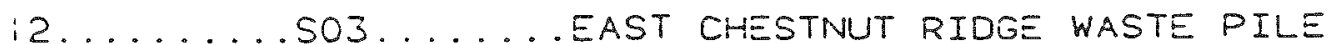

$13 \ldots \ldots . . . . . . . . .$. CONTAINERIZED WASTE STORAGE AREA

$14 \ldots \ldots \ldots . . . . . . .$. SOLASSIFIED CONTAINER STORAGE UNIT

BUILDING 9720-25

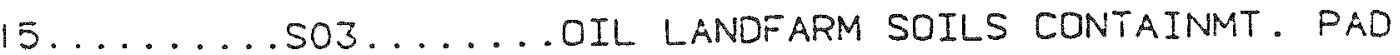

$16 \ldots . \ldots . . .503 \ldots . . .$. DISPOSAL AREA REMEDIAL ACTION

(DARA) SOLIDS STORAGE UNIT

$17 \ldots \ldots . . . .$. TO $1 \ldots$ URANIUM TREATMENT UNIT

SOI

$18 \ldots \ldots \ldots$........... INTERIM REACTIVE WASTE TREATMT AREA

$19 \ldots \ldots . . . . . . .$. SOILILDING $9720-12$ CLASSIFIED

CONTAINER STORAGE AREA

$20 \ldots \ldots . . . . . .$. SO $1 \ldots R A$ AND PCB CONTAINER

STORAGE AREA. BUILDING 9720-58

$21 \ldots \ldots . . . . .501 \ldots$ BUILDING $9201-4$ CONTAINER

STORAGE AREA

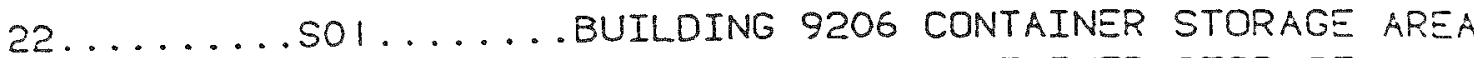

$23 \ldots . . . .$. SO $\ldots . . .$. BUILDING 9212 CONTAINER STORAGE AREA 


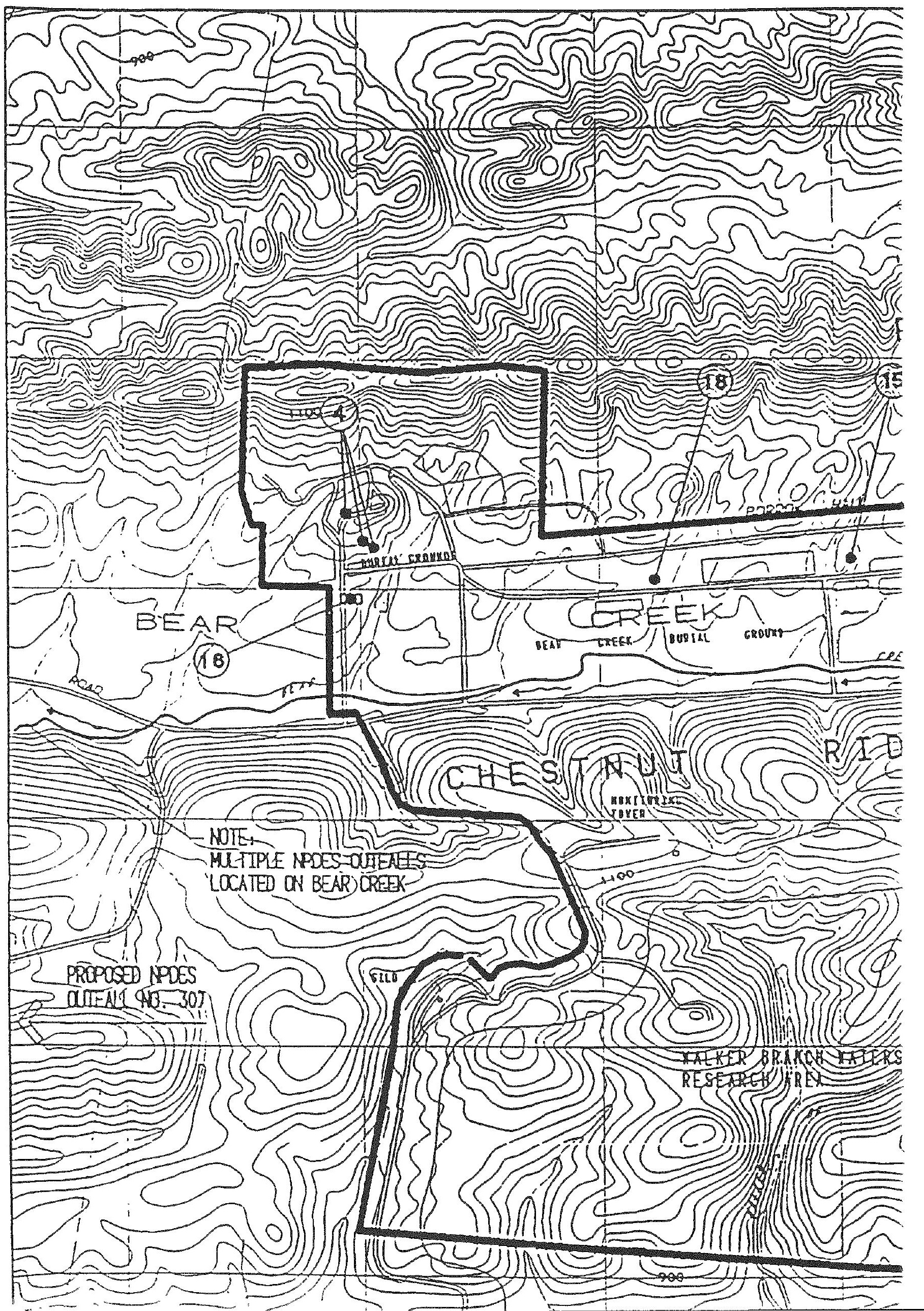




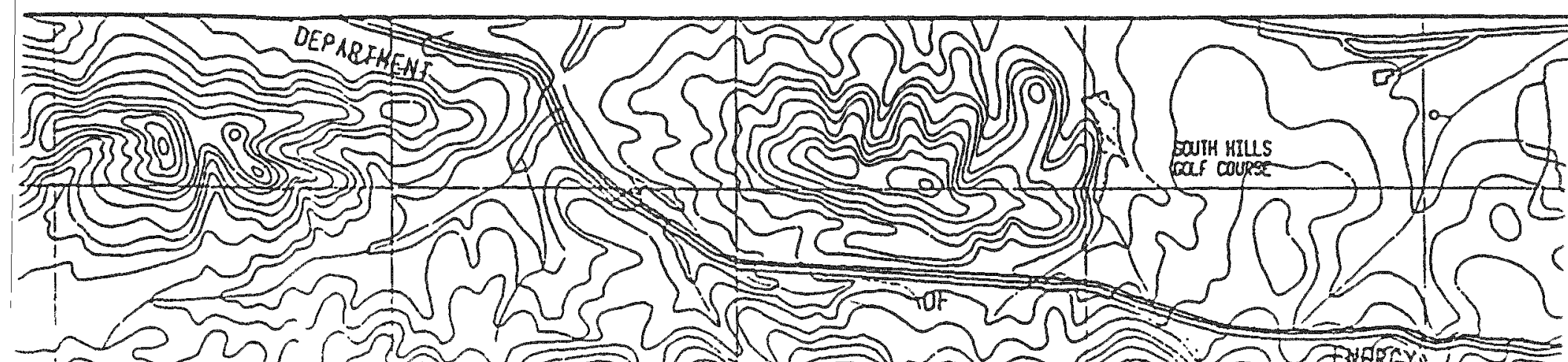

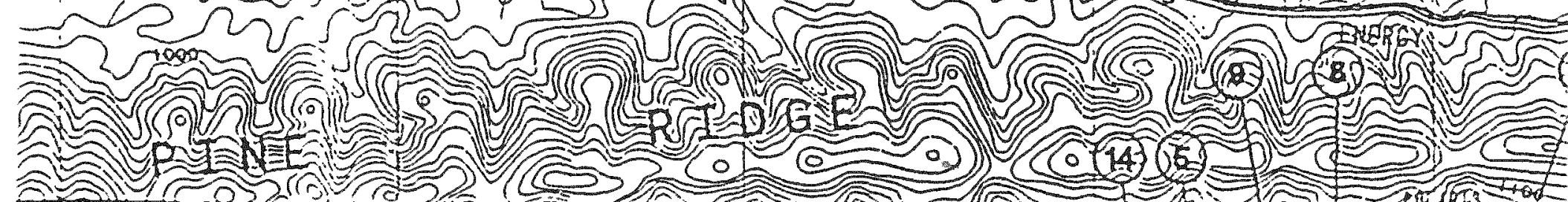

(2)
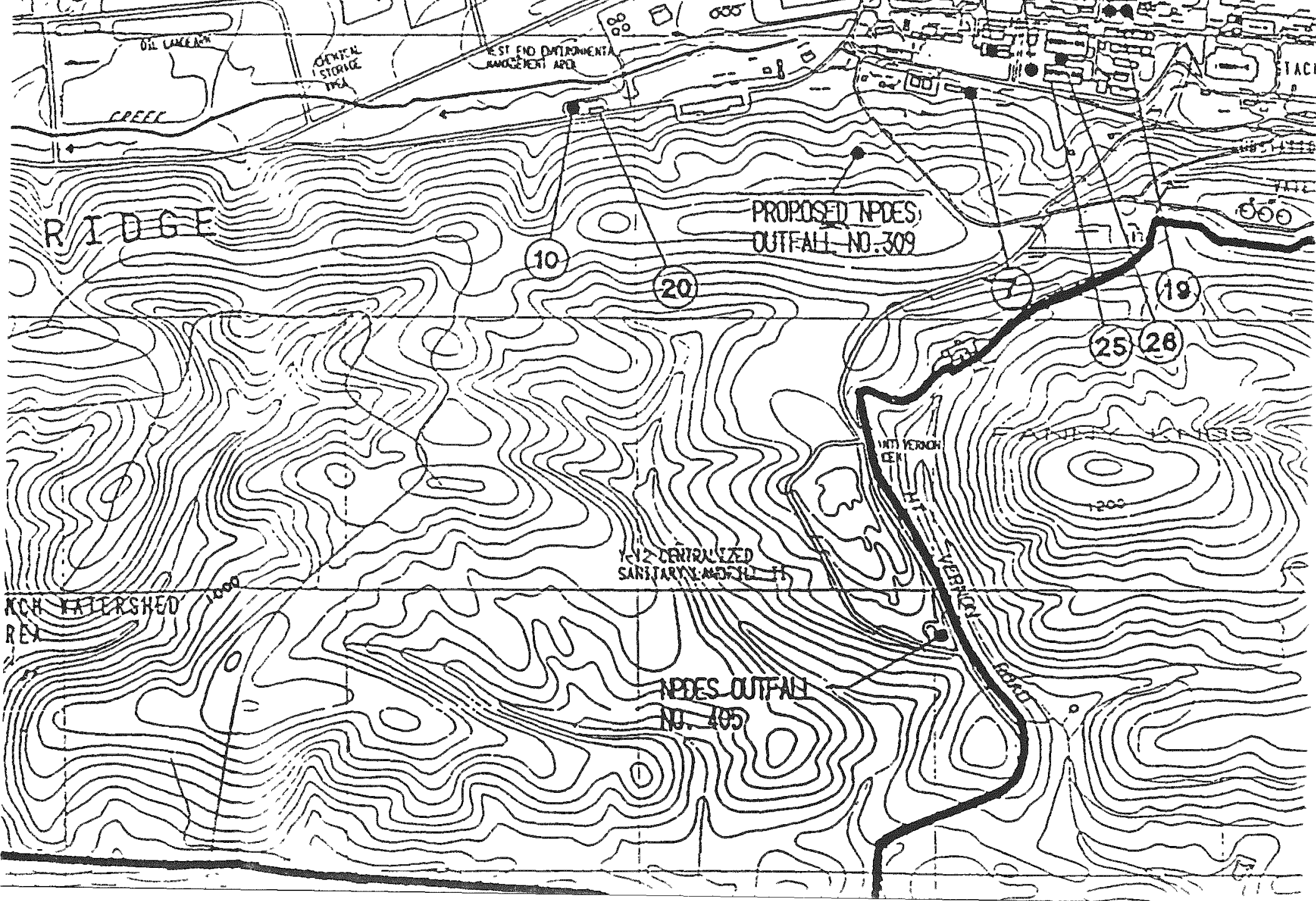


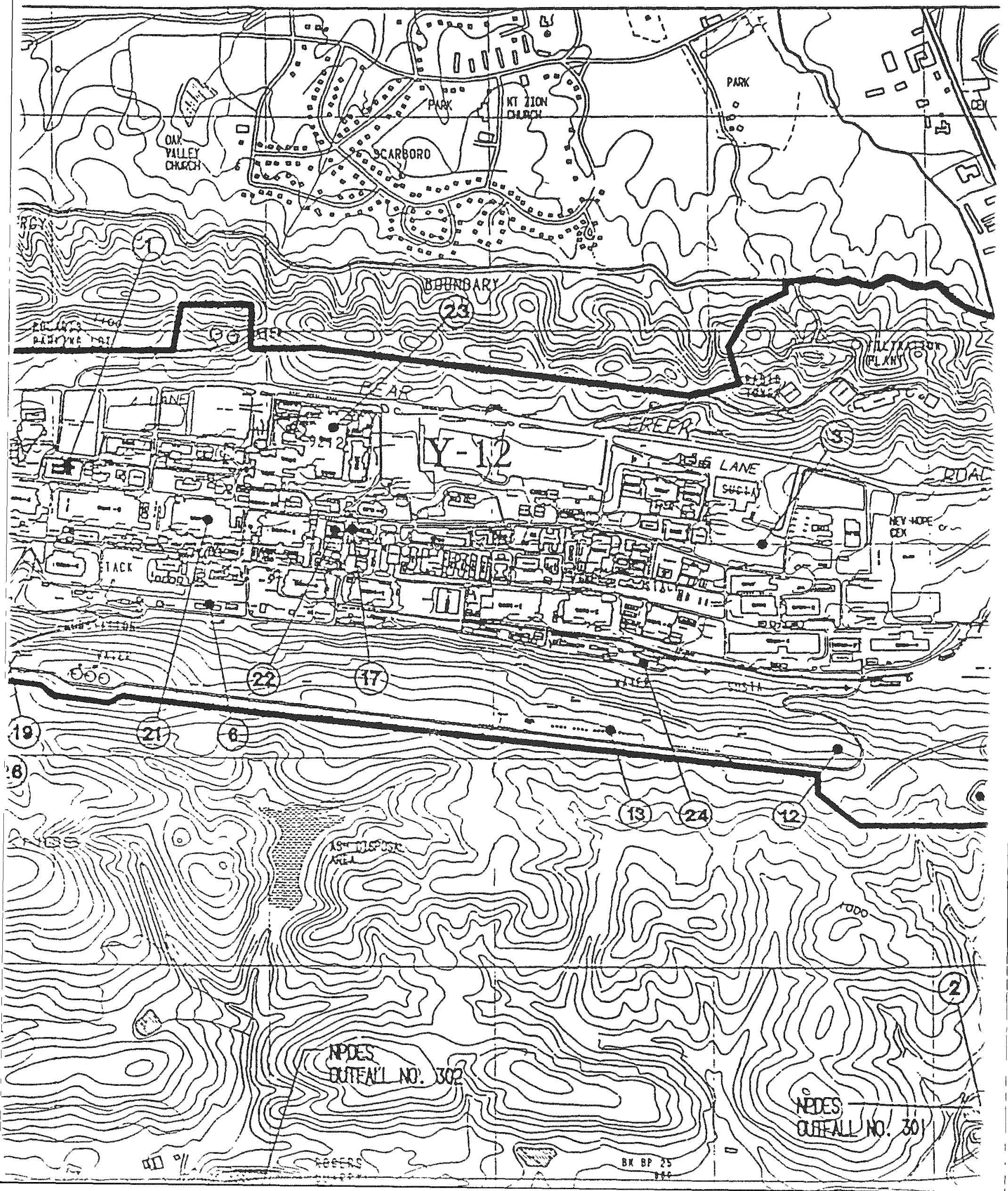




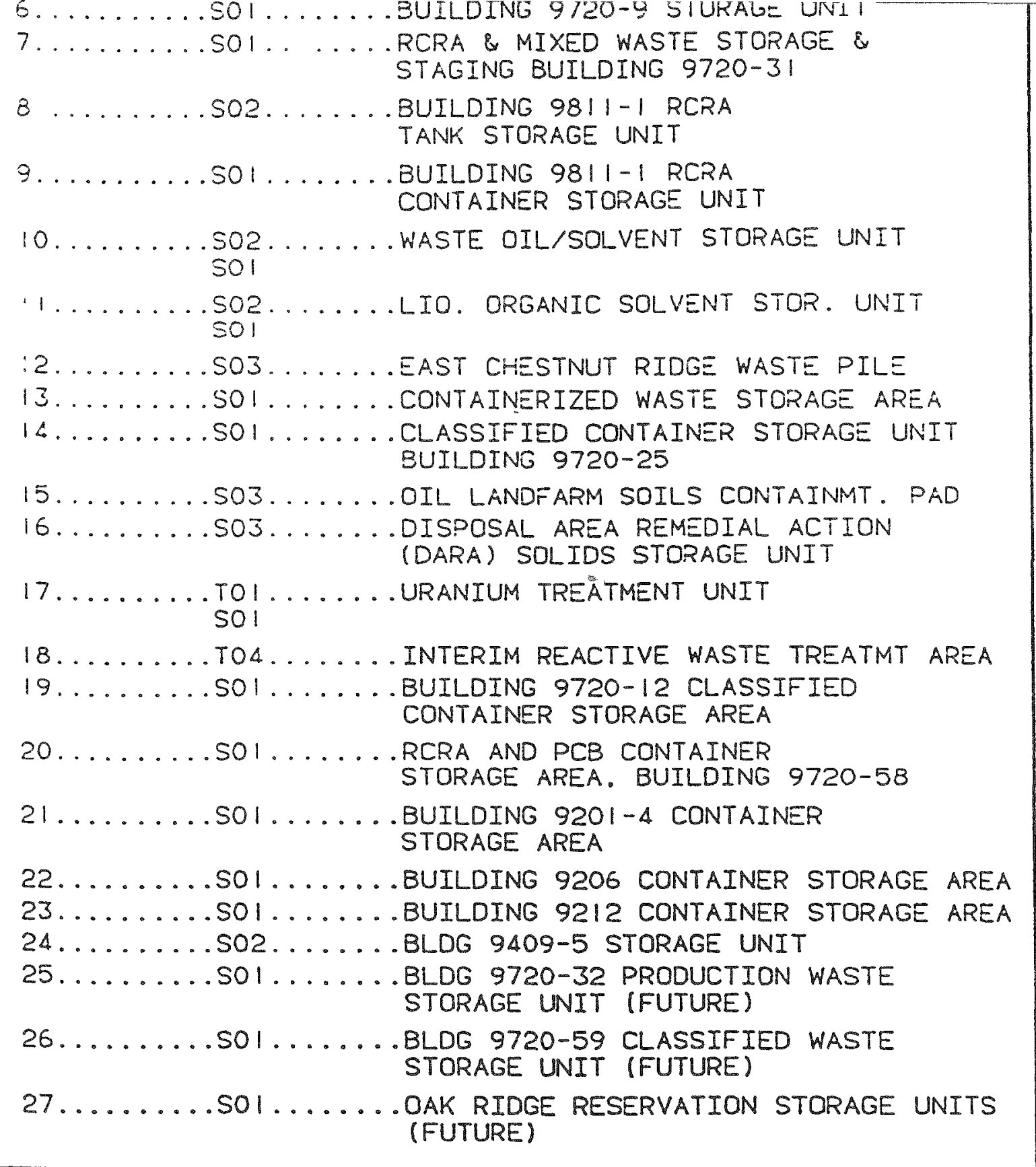

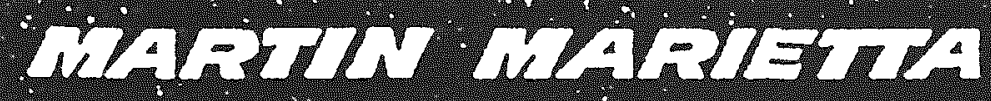

Y-12 PLANT RCRA MASTE UNT LOCATIONS

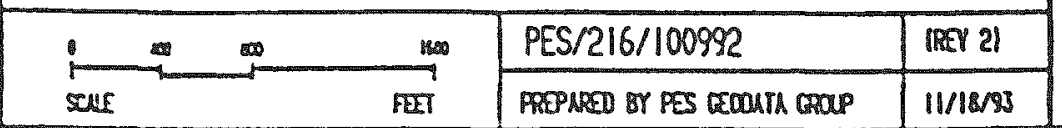




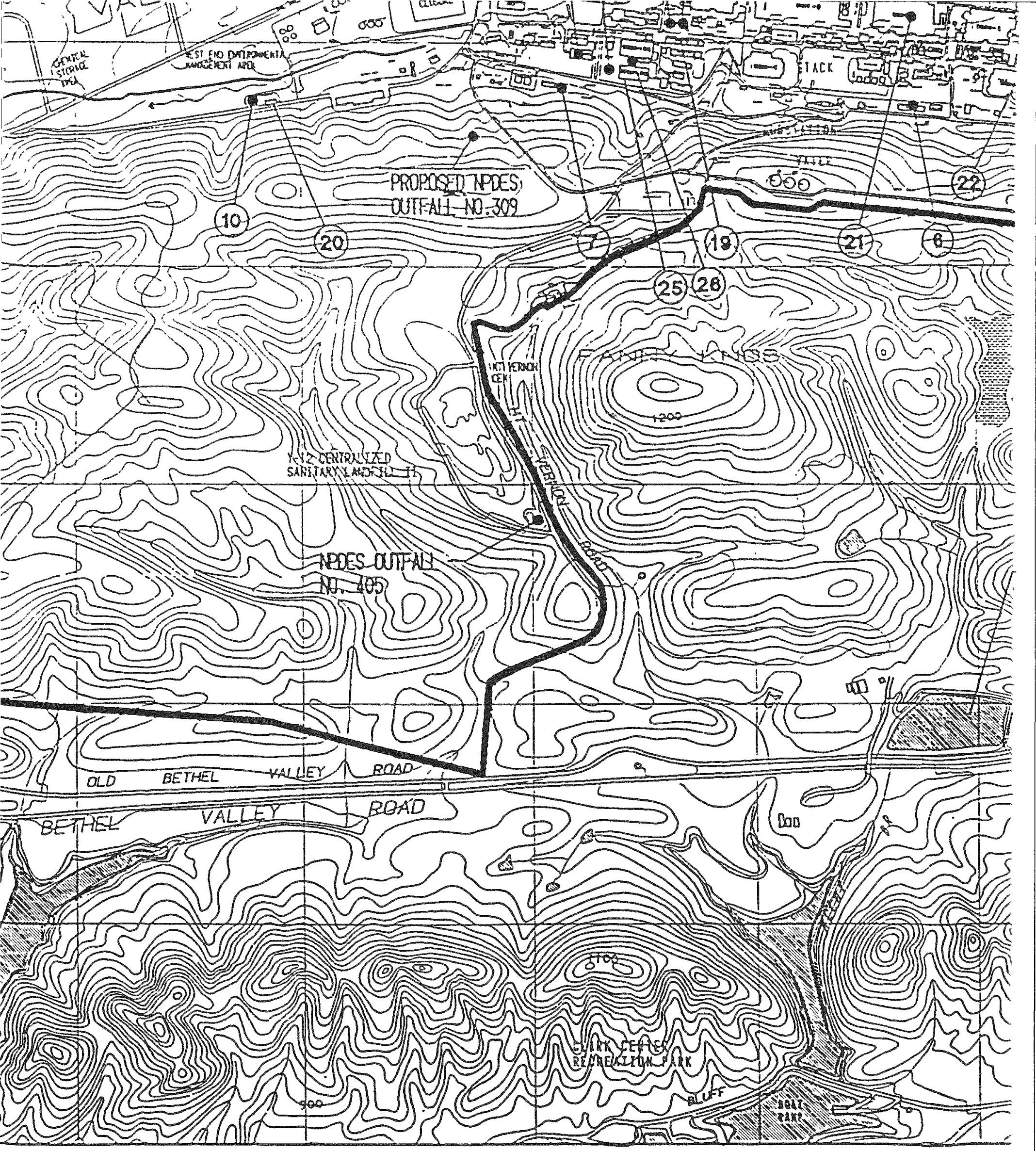




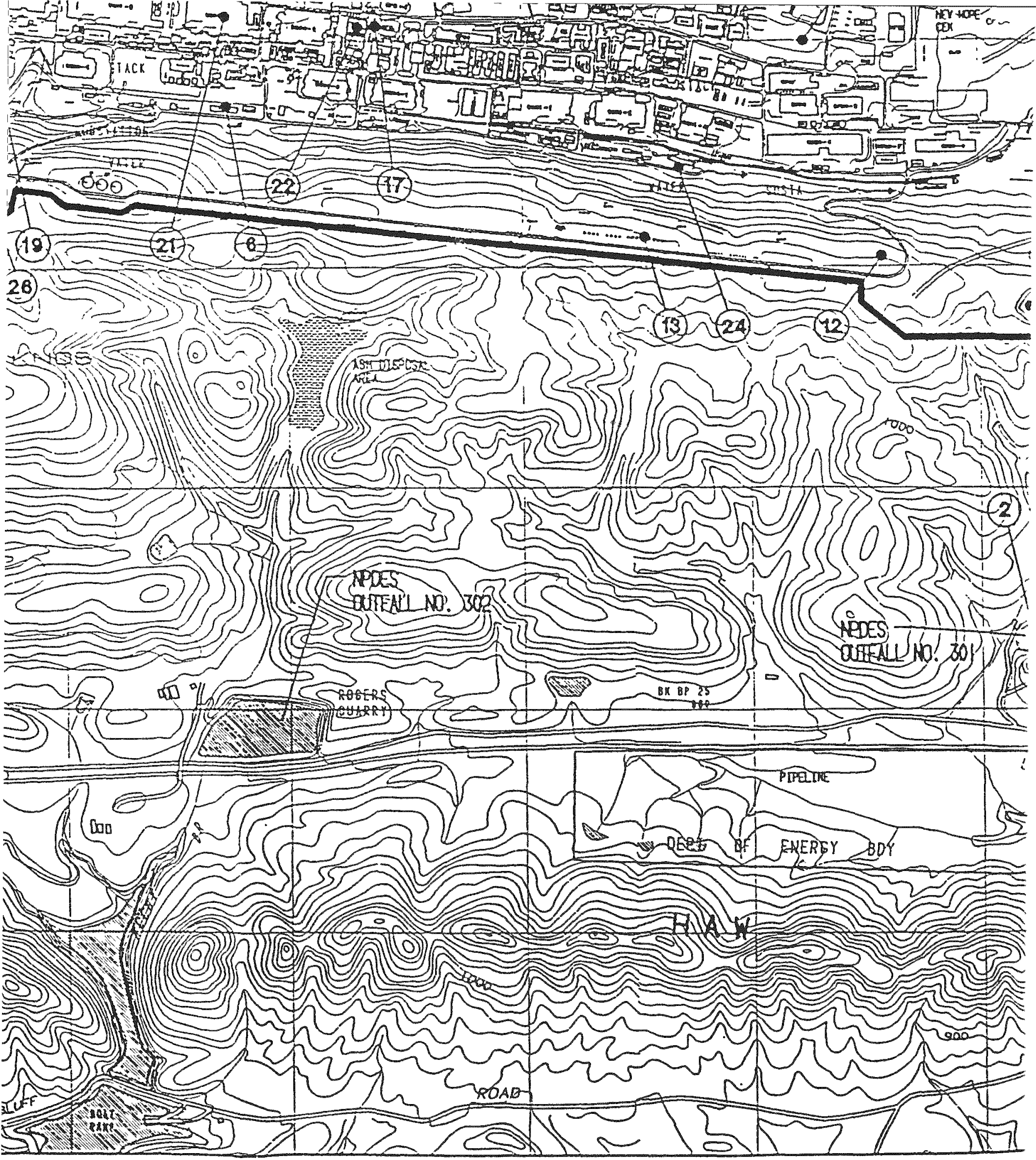




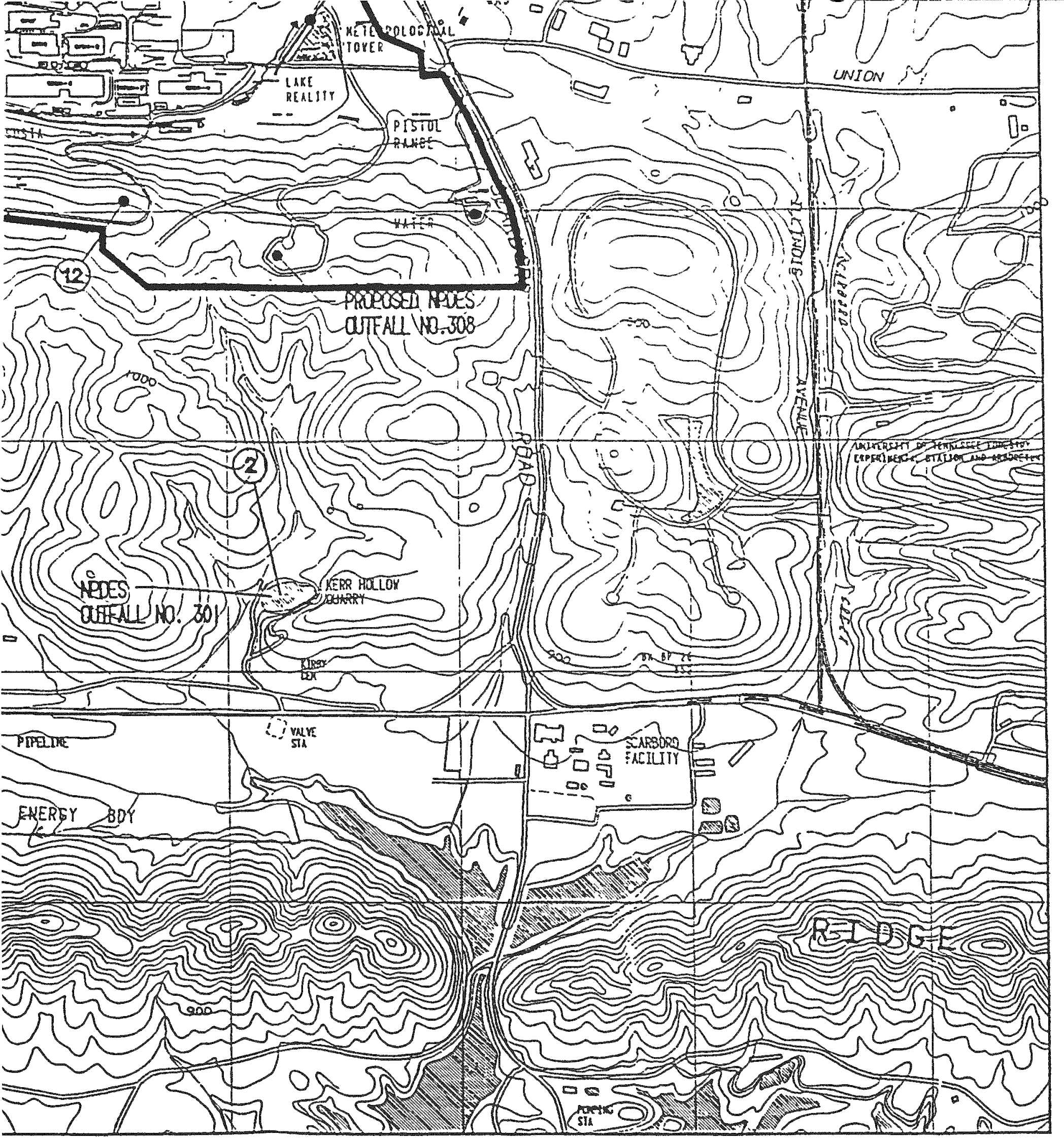




\section{$Y-12$}

F尔

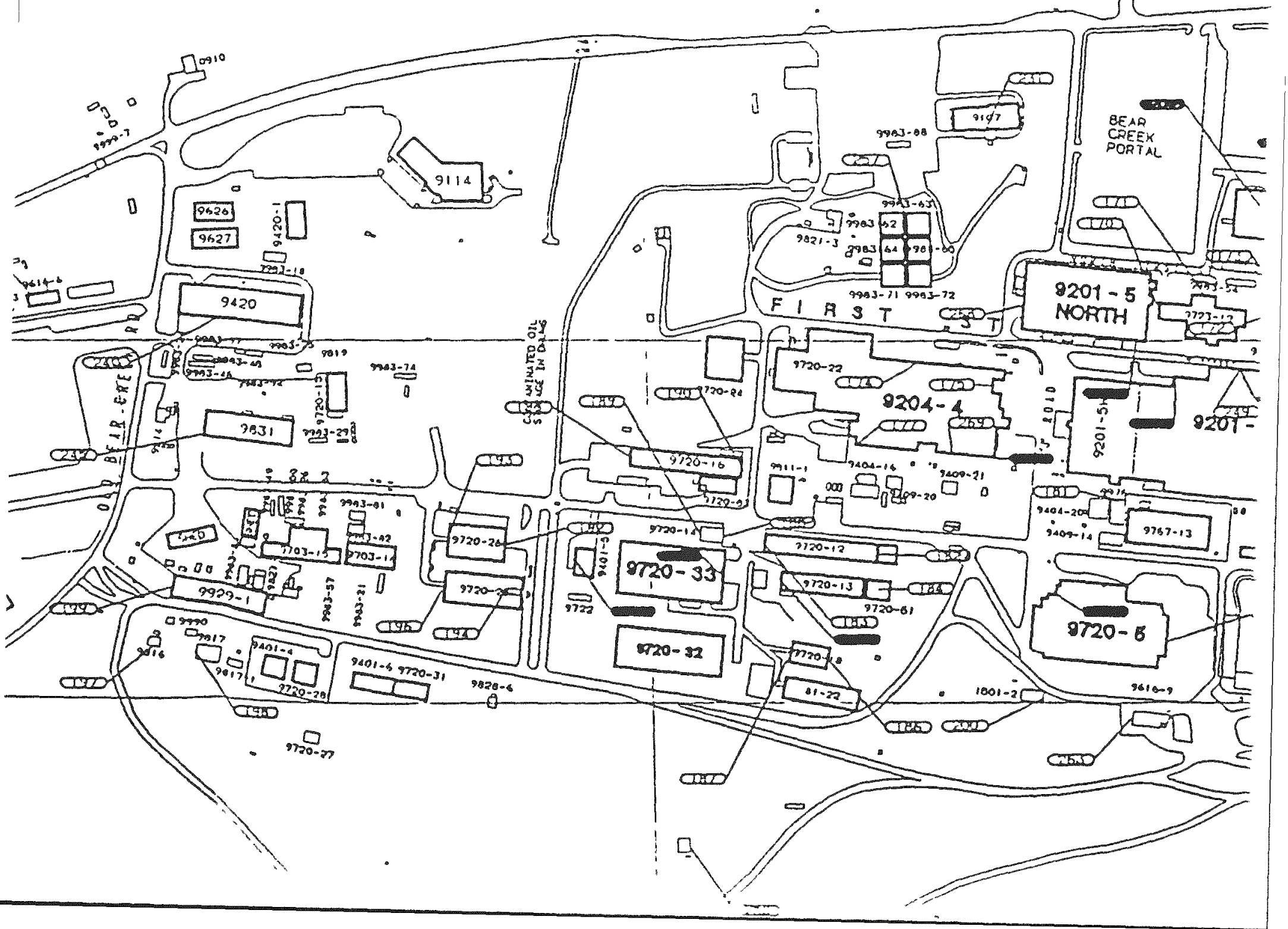




\section{FLAIT LUADIII}
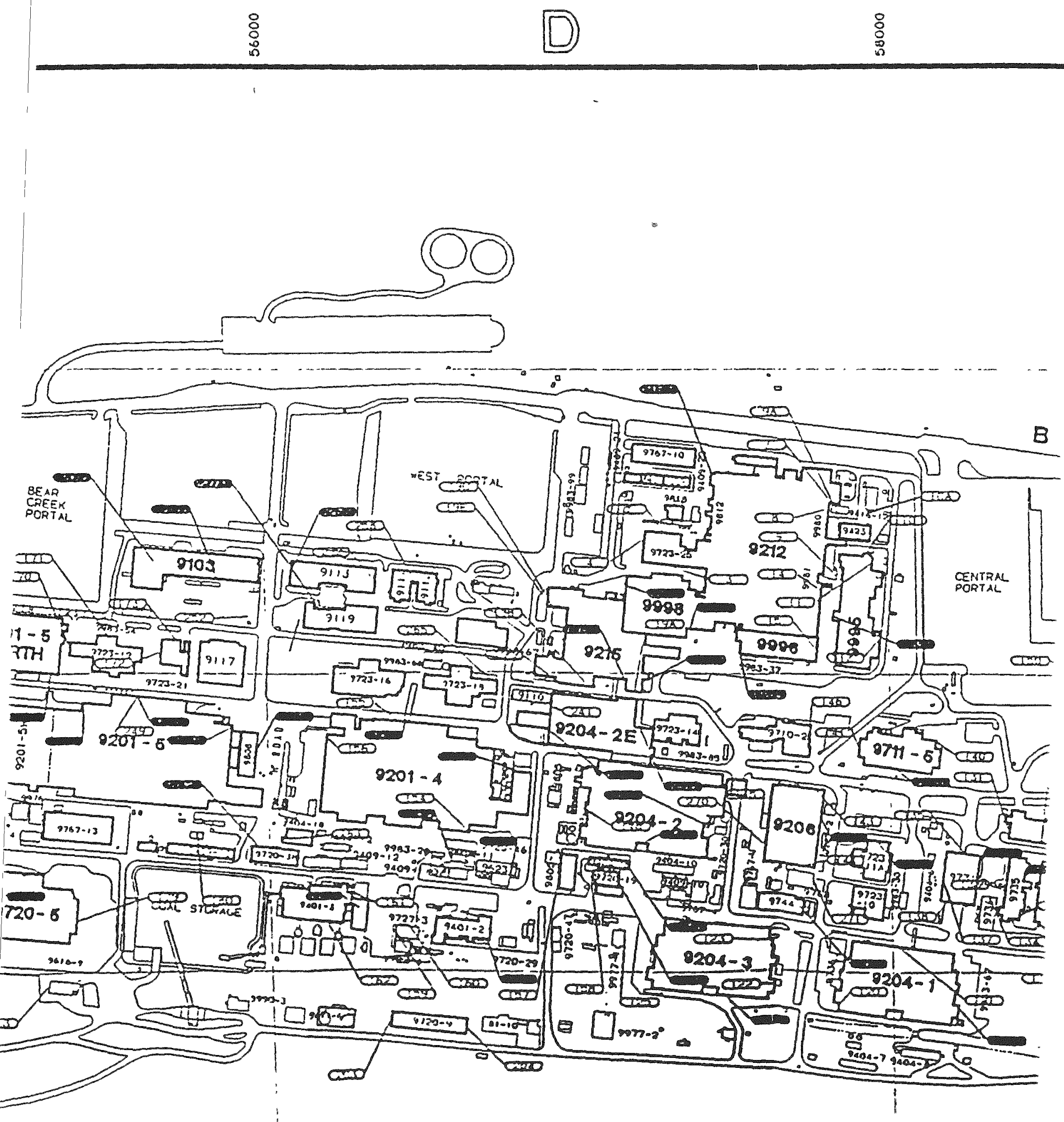

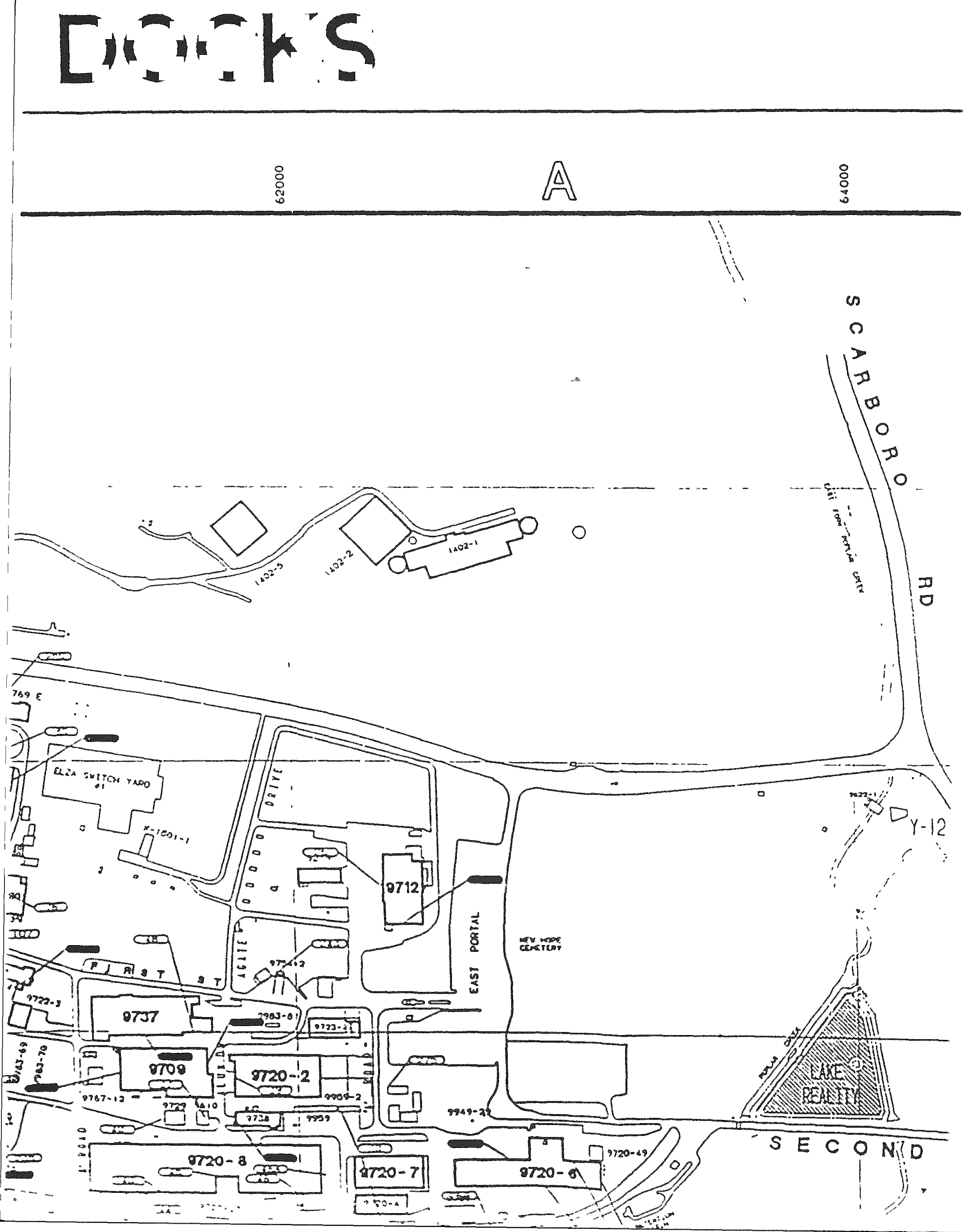


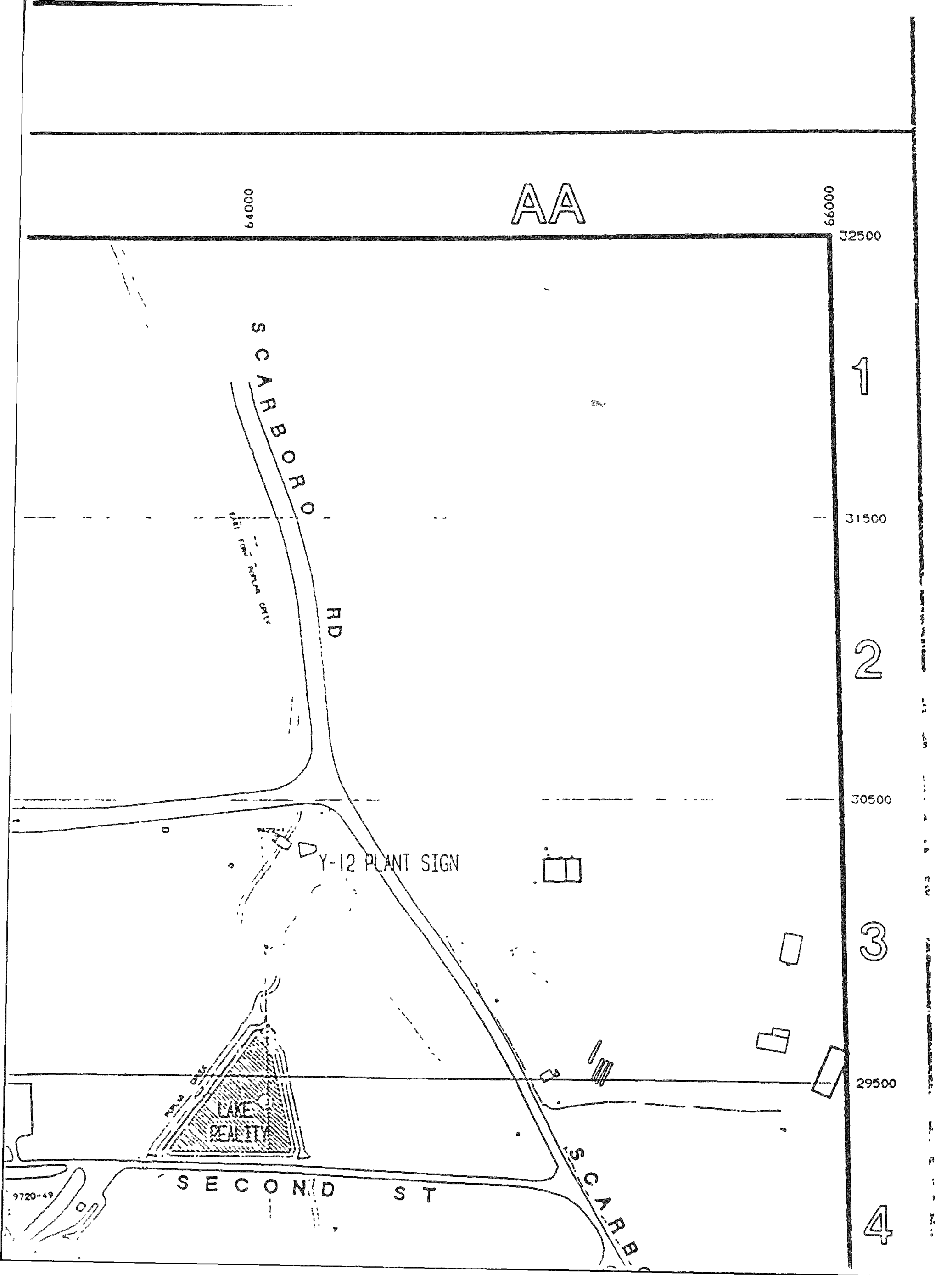




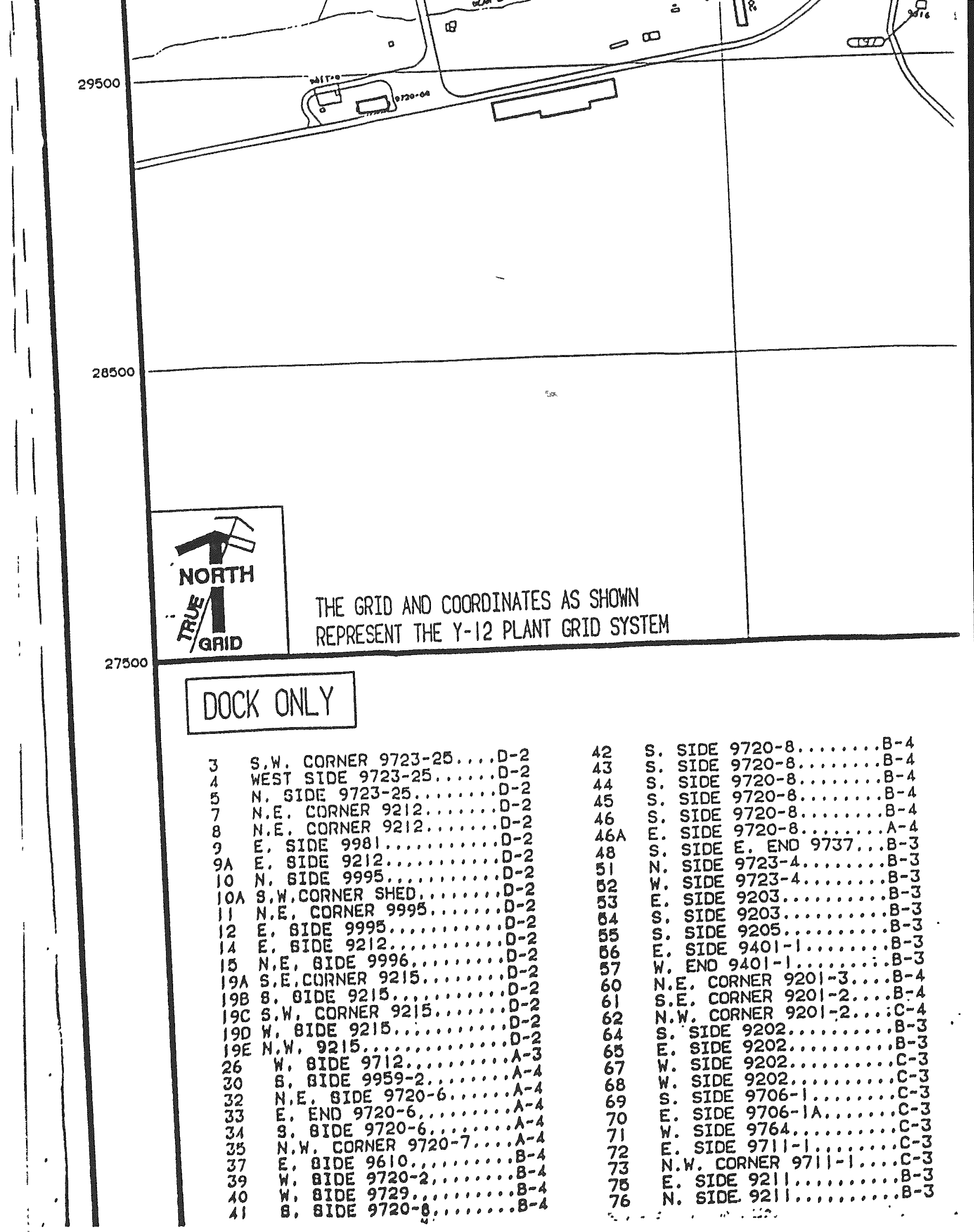




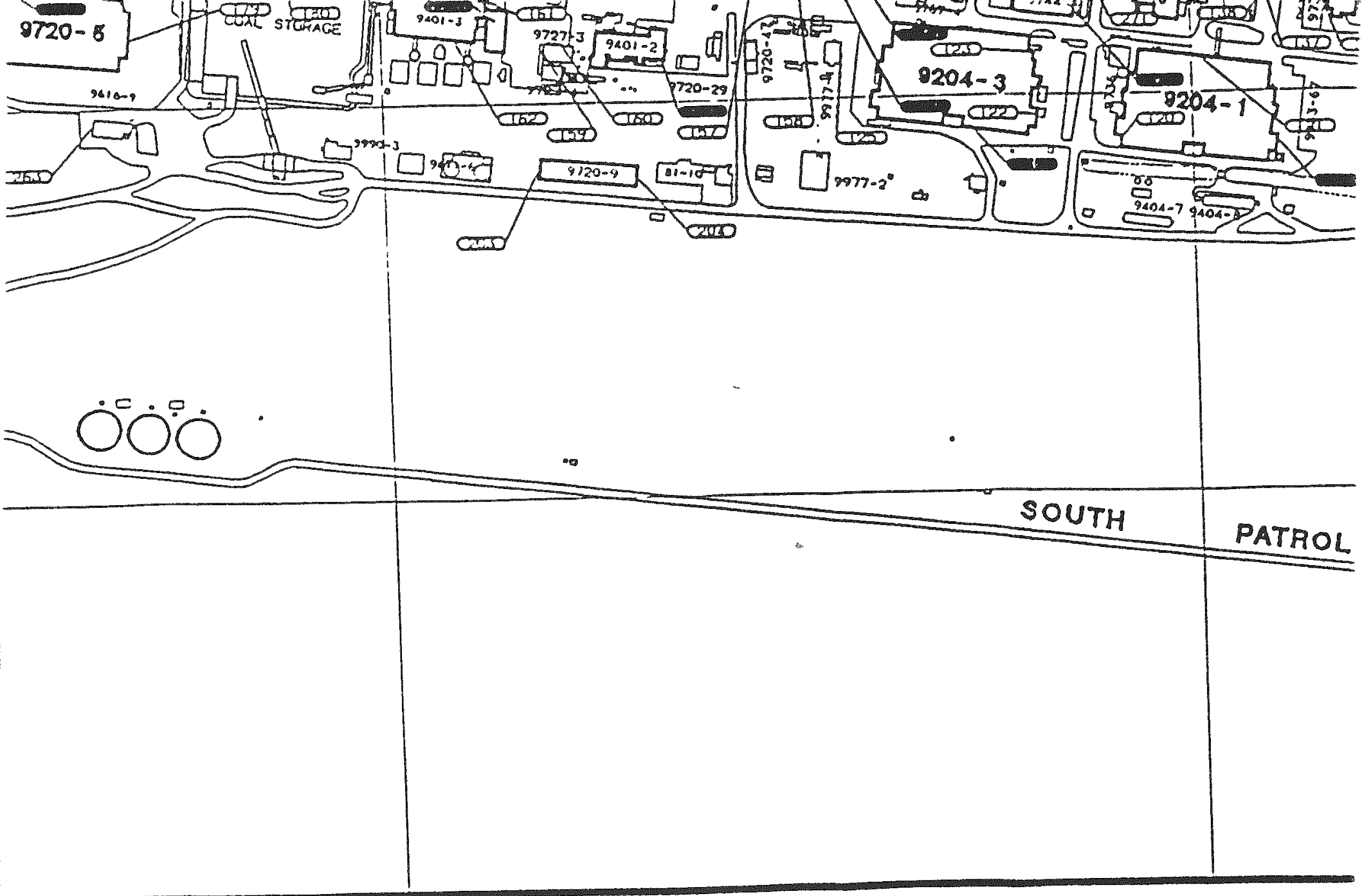

C-4 148 W. SIDE $9204-2 \ldots \ldots . .00-3$

$C-4$

$8-4$

C -3

$\mathrm{C}-3$

. $C-3$

C -4

$\mathrm{C}-\mathrm{C}$

. $C-4$

. $C-3$

$0-4$

$.8-4$

$0-3$

$c-3$

- C-3

$\therefore C-3$

. $\mathrm{C}-3$

. $\mathrm{C}-\mathrm{3}$

. $\mathrm{C}-3$

. $\mathrm{C}-3$

. $\mathrm{C}-3$

. $\mathrm{C}-3$

- $\mathrm{C}-3$

$.0-3$

. D- 3

. . D-3

$.0-3$

150 N. SIDE $9704-2 \ldots \ldots . . . C-3$

154

155

156

157

158

159

160

161

162

163

170

.171

172

$-173$

174

175

177

179

180

181

182

183

184

186

187

188
S.E. CORNER 9201-4...D-3

N. SIDE $9201-4 \ldots \ldots . . .0-3$

N.W. CORNER 9201-4...D-3

W. SIDE $9805-1 \ldots . . .0-3$

W. SIDE $9720-19 \ldots . . .0-3$

W. SIDE $9727-3 \ldots . . . . D-3$

N. SIDE $9727-3 \ldots . . . .0-3$

N.E. CORNER 94OI-3...D-3

S. SIDE $9401-3 \ldots . . .0-3$

W. END $9404-18 \ldots \ldots . . . .0-3$

W. END $9723-19 \ldots . . . E-2$

N. SIDE $9723-19 \ldots . . . E-2$

W. END $9723-21 \ldots . \ldots-2$

N. SIDE $9723-2 i \ldots E-2$

N. SIDE $9204 \ldots 4 \ldots \ldots . . . . E-3$

N.E. CORNER $9204-4 \ldots E-3$

S.W. CORNER 9204-4...E-3

E. SIDE $9720-5 \ldots . . . E-3$

N. SIDE $9404-13 \ldots . . . E-3$

N. SIDE $9976 \ldots \ldots \ldots . . . . . .$.

E. END $9720-12 \ldots \ldots-3$

W. END $9720-12 \ldots . . . E-3$

E. ENO $9720-13 \ldots \ldots$. ...

E. END $9720-18 \ldots \ldots-3$

W. END $9720-18 \ldots \ldots \ldots E-3$

E. ENO $9720-14 \ldots E-3$
193

194

196

197

198

199

200

203

204

210

211

222

226

228

229

230

231

232

233

234

238

236

237

238
W. ENO $9720-14 \ldots . . . E-3$

E. END $9720-16 \ldots . . . E-3$

W. END $9720-16 \ldots . . . E-3$

E. END $9720-26 \ldots \ldots F-3$

W. END $9720-26 \ldots . . . F-3$

E. END $9720-25 \ldots . . . F-3$

W. END $9720-25 \ldots \ldots F-3$

S. SIDE $9816 \ldots . . . . F-3$

W. END $9817 \ldots \ldots \ldots . . . . F-3$

W. ENO $9929-1 \ldots . . . F-3$

E. END $150 \mid-2 \ldots . . . . E-3$

W. ENO 9720-9....... D-4

E. ENO $9720-9 \ldots . . . .0-4$

W. SIDE $9732-1 \ldots \ldots-3$

S. SIDE $9706-2 \ldots \ldots . . . C-3$

W. ENO $9720-4 \ldots . . . . A-4$

\$. 8IDE $9766 \ldots . . . . .3$

S.W. CORNER $2203 \ldots . .8-3$

W. SIDE $9616 \ldots 6 \ldots A$

S. SIDE $9106 \ldots . . . . .3$

S. SIOE $9107 \ldots . . . . .2-2$

N. SIDE $9108 \ldots . . . .8 .4$

S. SIDE $9109 \ldots . . . . .3-3$

W. SIDE $9102-1 \ldots \ldots$.

S.W.CORNER $9102-2 \ldots . .1-4$

E. SIDE $9104-1 \ldots . . . B-4$

E. SIOE $9104-2 \ldots . . .0-4$

E. SIDE $9104-3 \ldots . . .0-4$
239

240

241

242

243

244

245

249

250

251

252

253

257

258

260

263

268

266

267

268

269

270

271

272

275
N. SIDE

S. SIOK

S.E. Cl

E. SIDE

S. SIDE

E. SID!

S. W. C:

N. 920

S. SID

H. SID

S.E. C

S. 911

N.BETW

E. SID

E. SIC

W. SIC

N.E.?

H. SIC

. NIDE

W. SIC

3. SIC

W. SIC

E. SIC

E. SIC

W. $S I L$ 


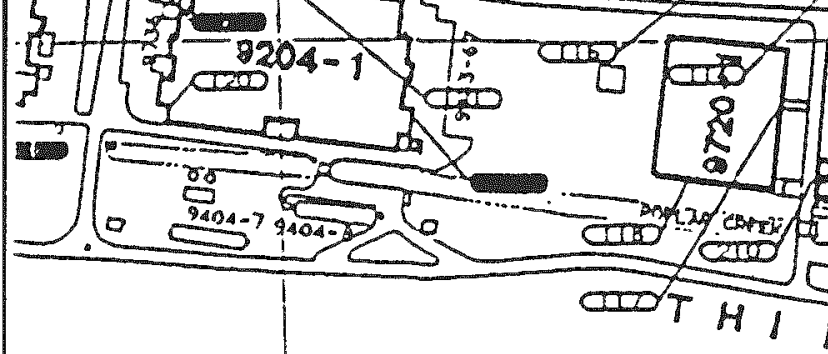
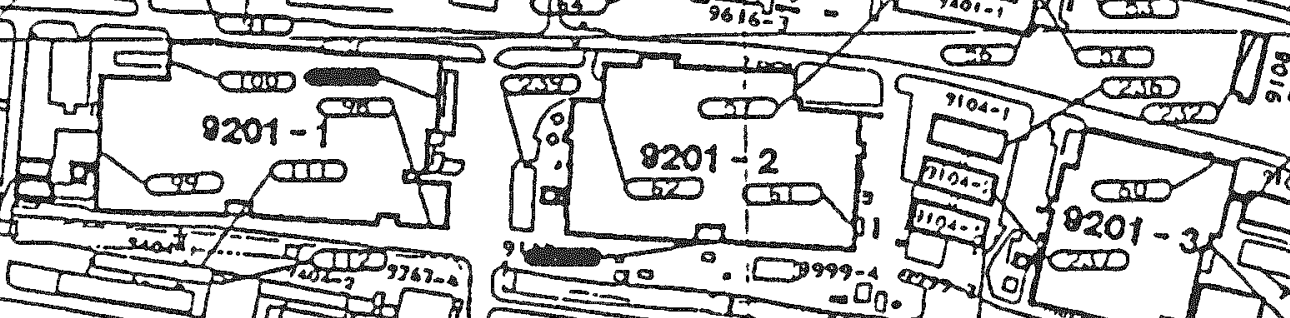

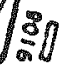
1.

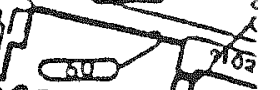
H. Tlon 10.3 s 5

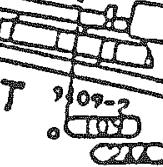

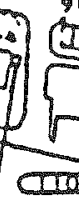

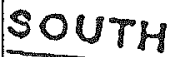

PATAOL

239

240

241

242

243

244

245

249

250

\section{1}

252

253

257

258

260

263

265

266

267

268

269

270

271

272

275
N. SIDE $9105 \ldots \ldots \ldots . C-4$

S. SIDE $9420 \ldots \ldots \ldots \ldots$ F-2

S.E. CORNER 9110..... D-3

E. SIDE $9720-39 \ldots . . .8-4$

S. SIDE $9754-2 \ldots \ldots . B-3$

E. SIDE 9767-8........

S.W. CORNER $9831 \ldots . .$. .F -3

N. $9201-52$ FL RP..E-2

S. SIDE $9769 \ldots \ldots \ldots .8-2$

W. SIDE $9769 \ldots . . . . .8-2$

S.E. CORNER 9983-41,.E-2

S. $9111,9112 \ldots \ldots \ldots .0 .2$

N.BETWN 9983-62 \& 63.E-2

E. SIDE $9824-4 \ldots \ldots \ldots$...

E. SIDE $9725 \ldots . . . . . A-4$

W. SIDE $9616-9 \ldots \ldots . E-3$

N.E. $9723-18 \ldots \ldots \ldots D-3$

W. SIDE 9116 RM. $135 . . C-3$

N.SIDE E END 97149 MI.W Y-12

W. SIDE $9201-5$ N.......E-2

S. SIDE $9204-4 \ldots \ldots \ldots E-3$

W. SIDE $9206 \ldots \ldots . . . .0-3$

E. SIDE $9720-17 \ldots \ldots . . .0-3$

E. SIDE $9103 \ldots \ldots \ldots . . . .2$

W. SIDE $9983-A H . . . . . A A-4$

\section{6}

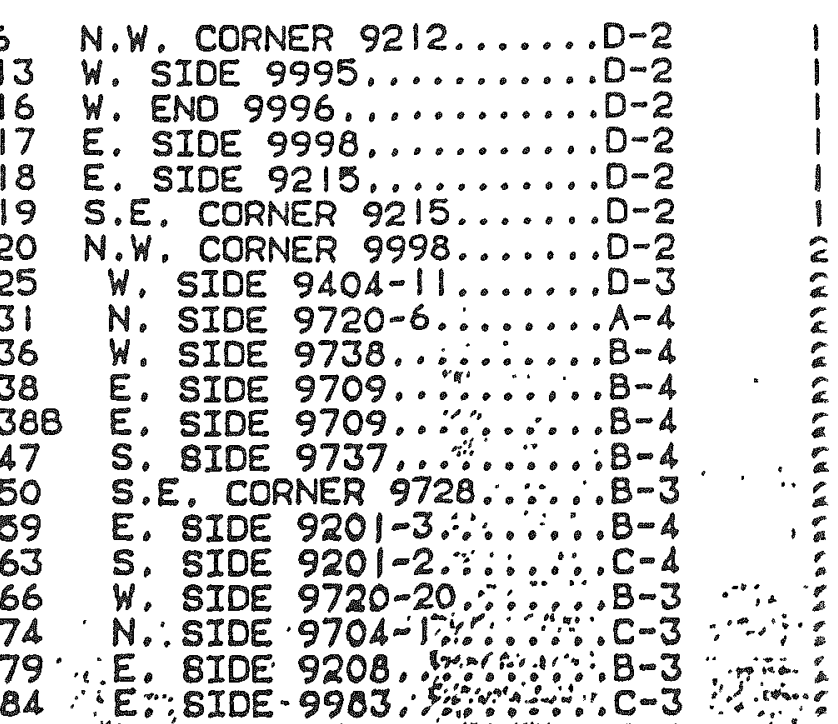

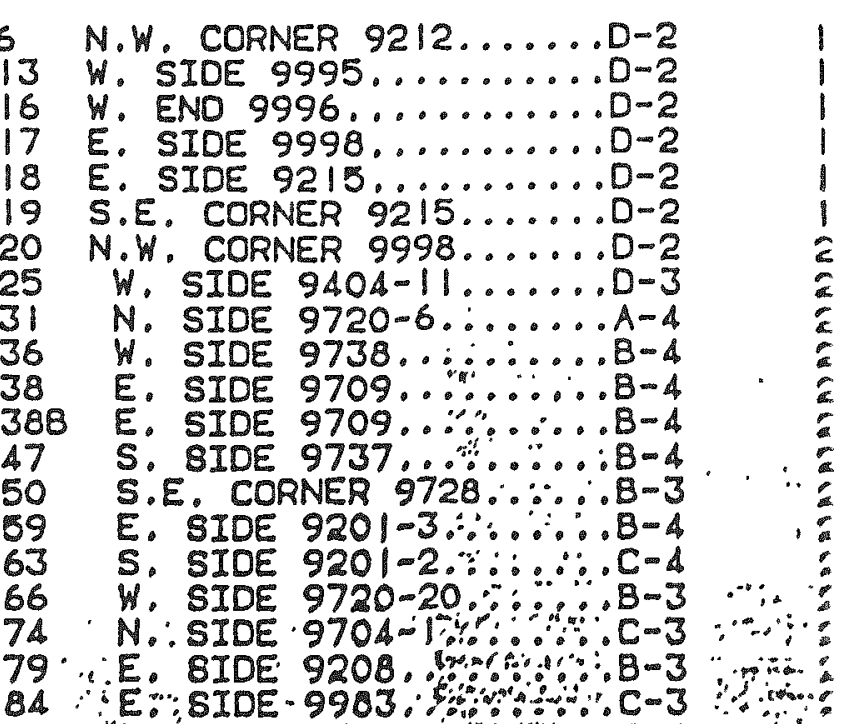

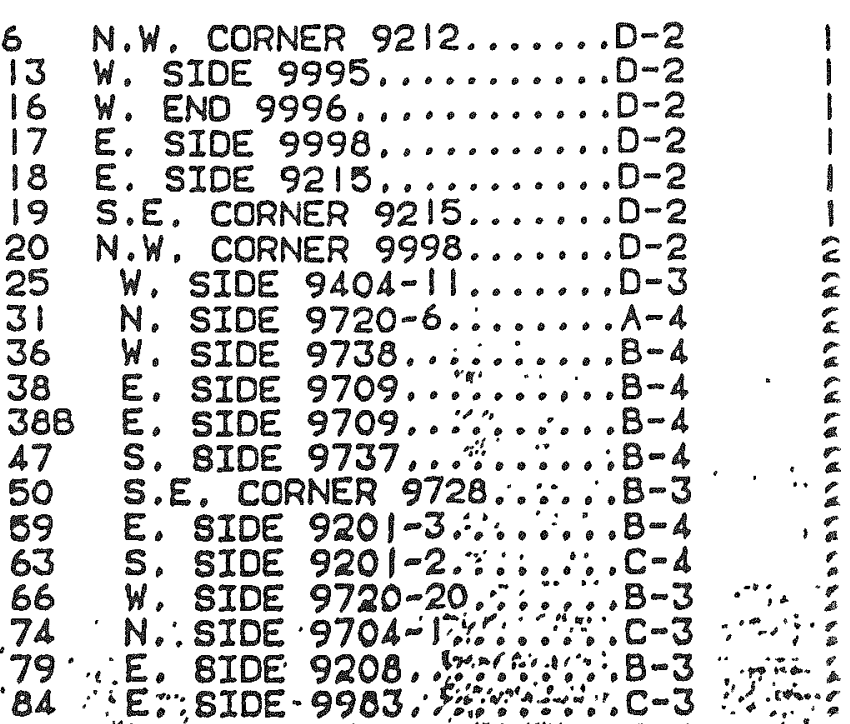

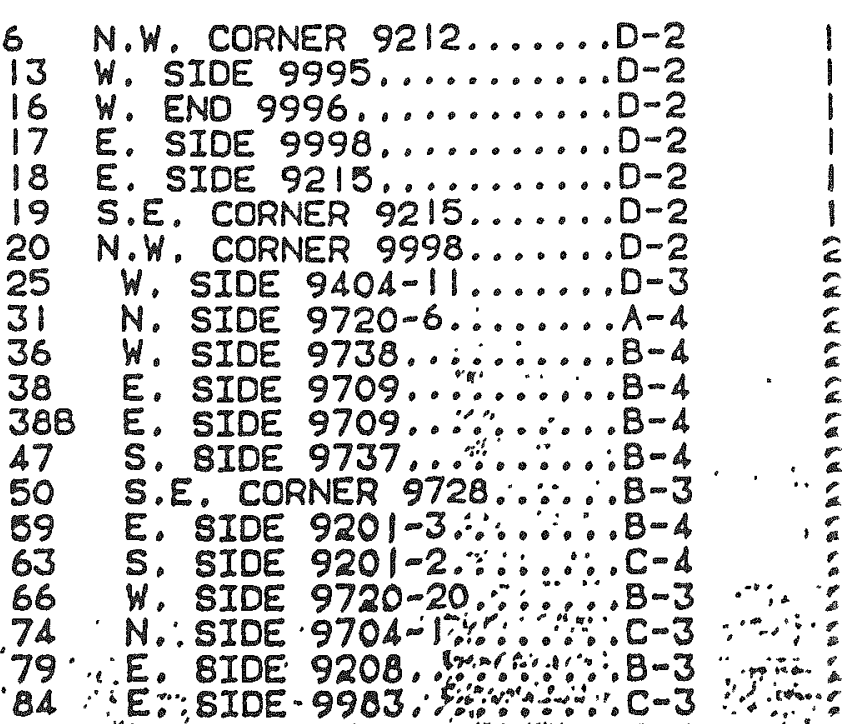

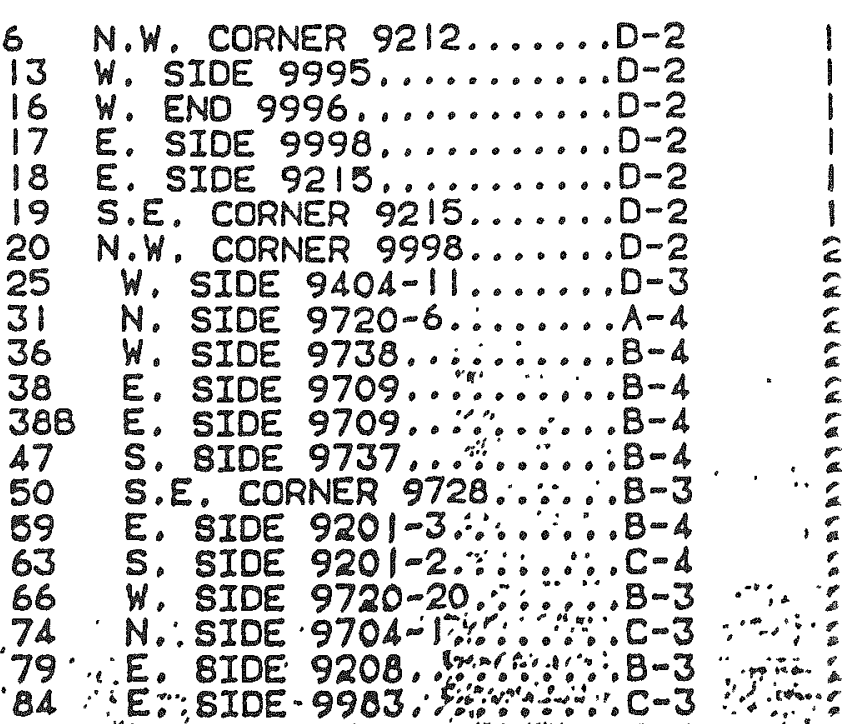

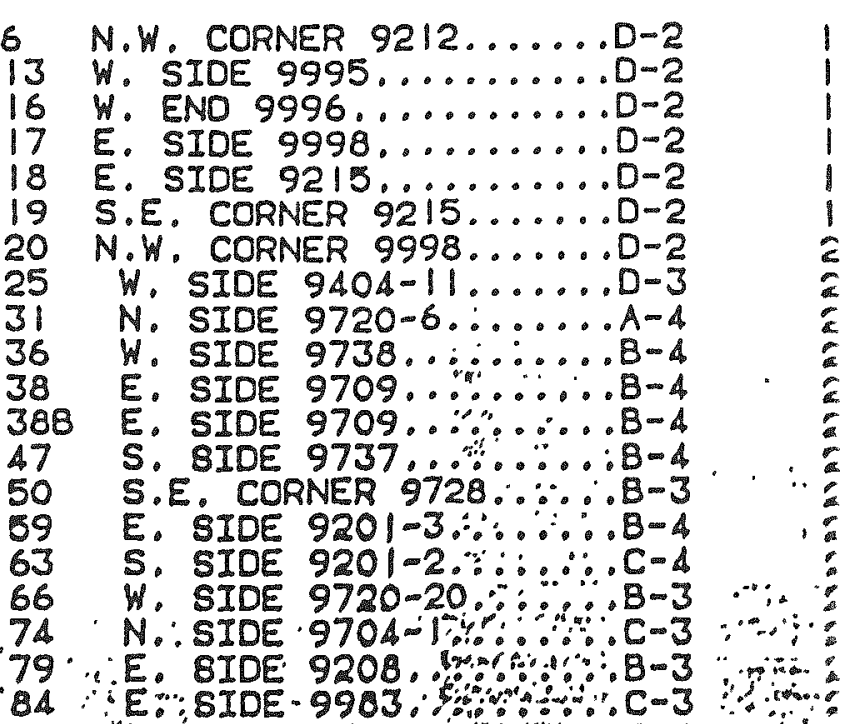

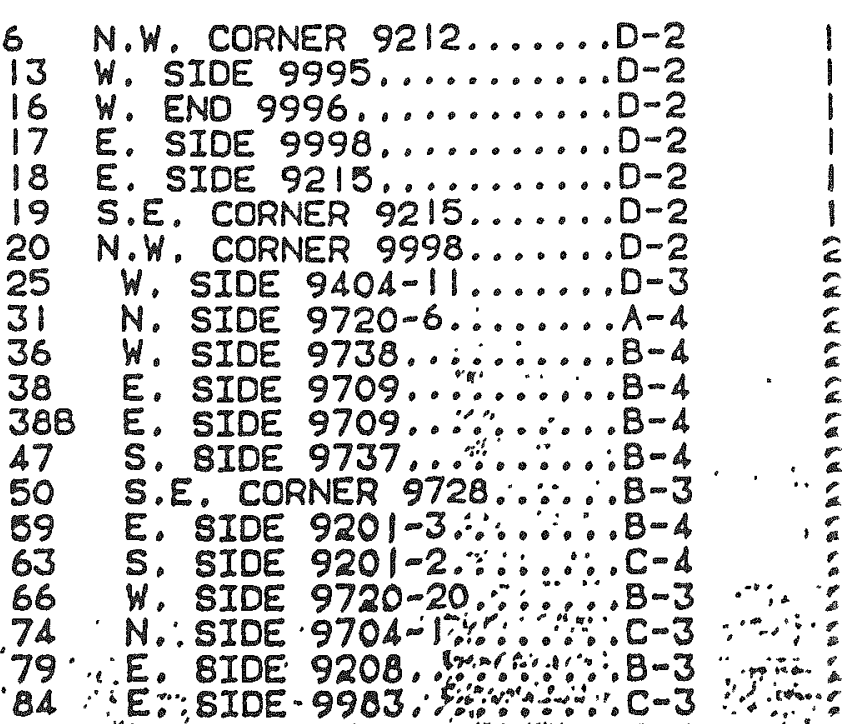

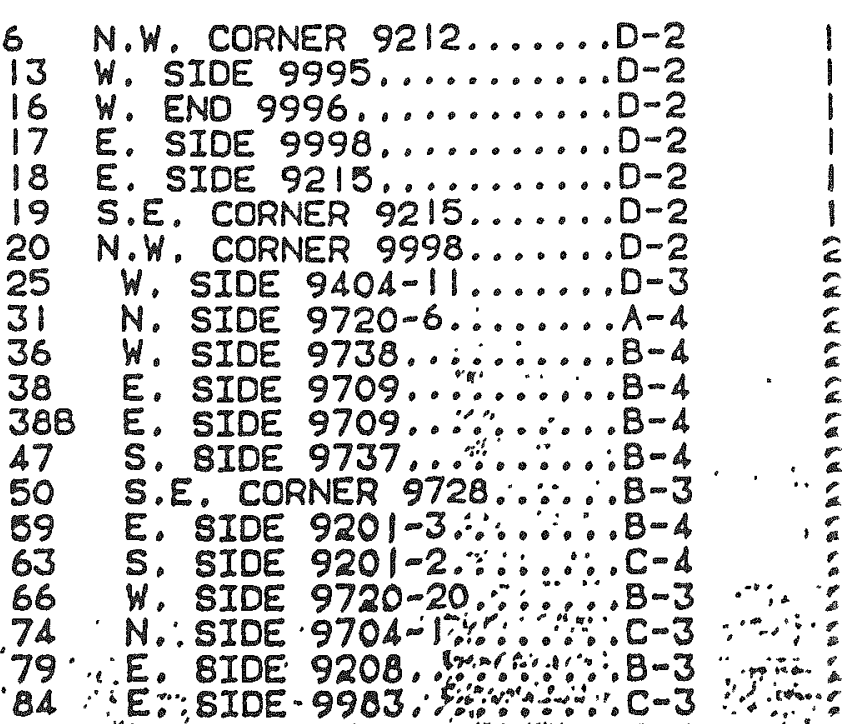

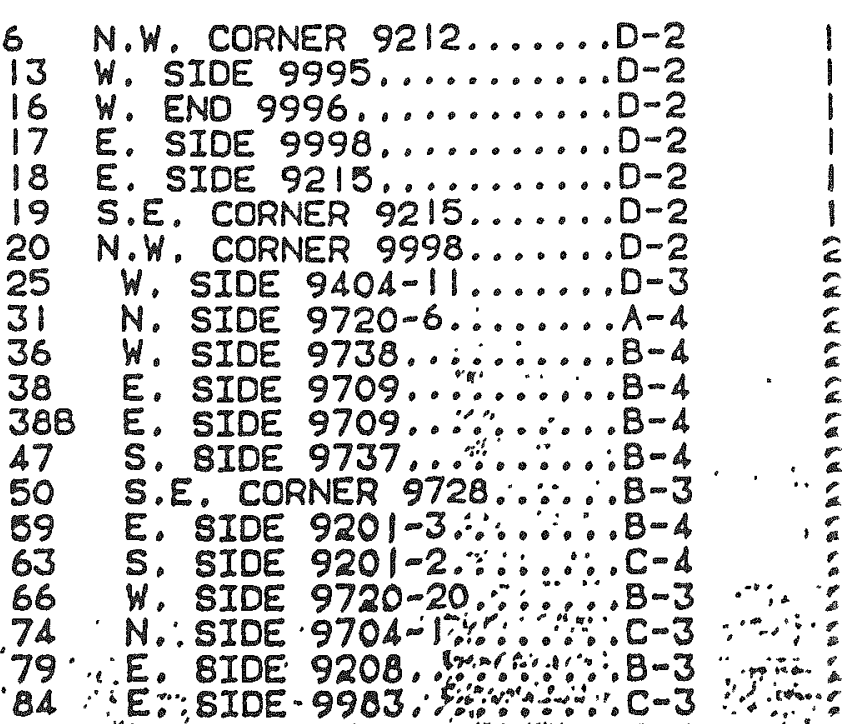

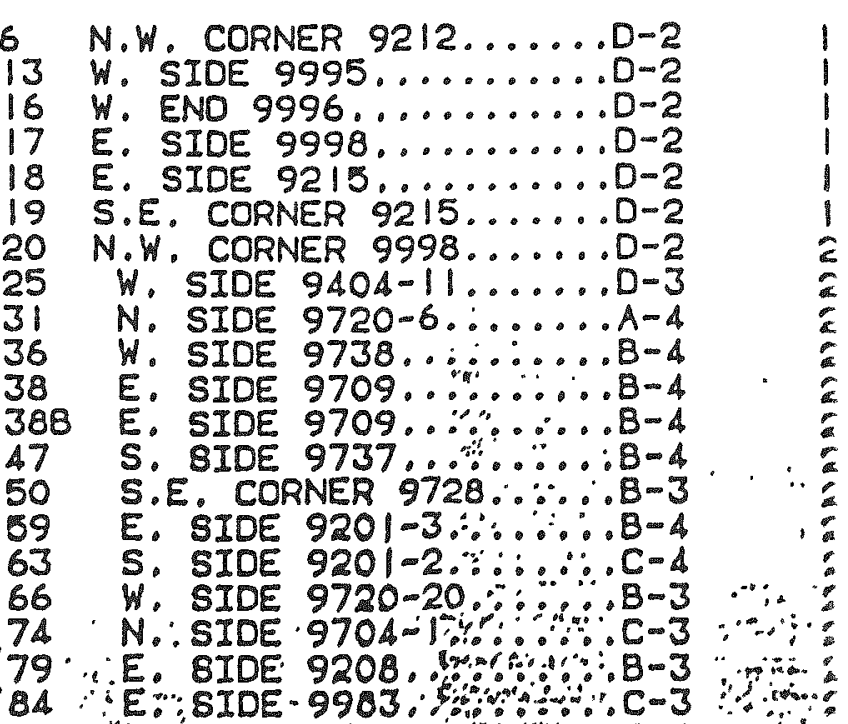

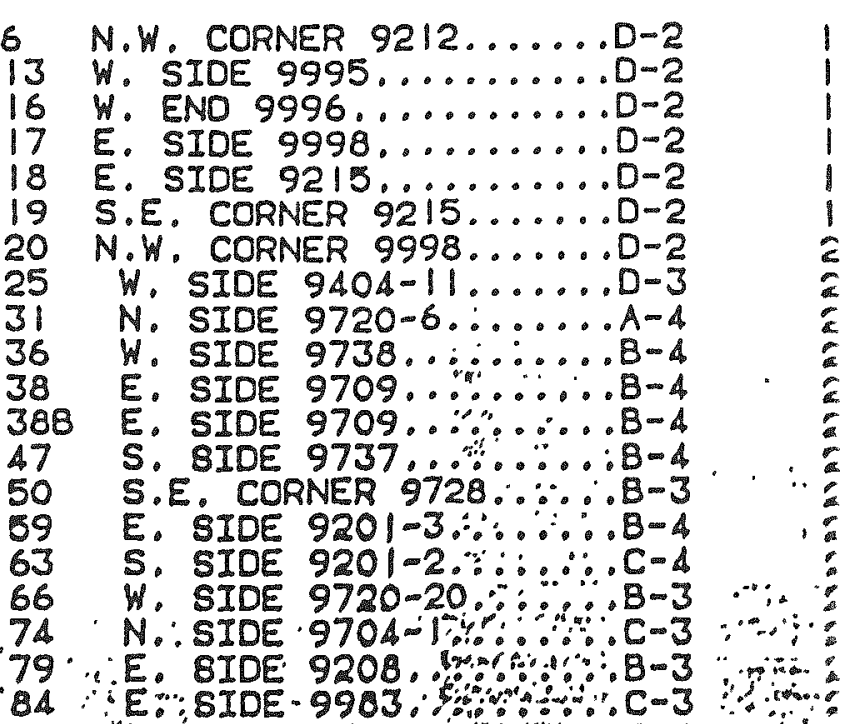

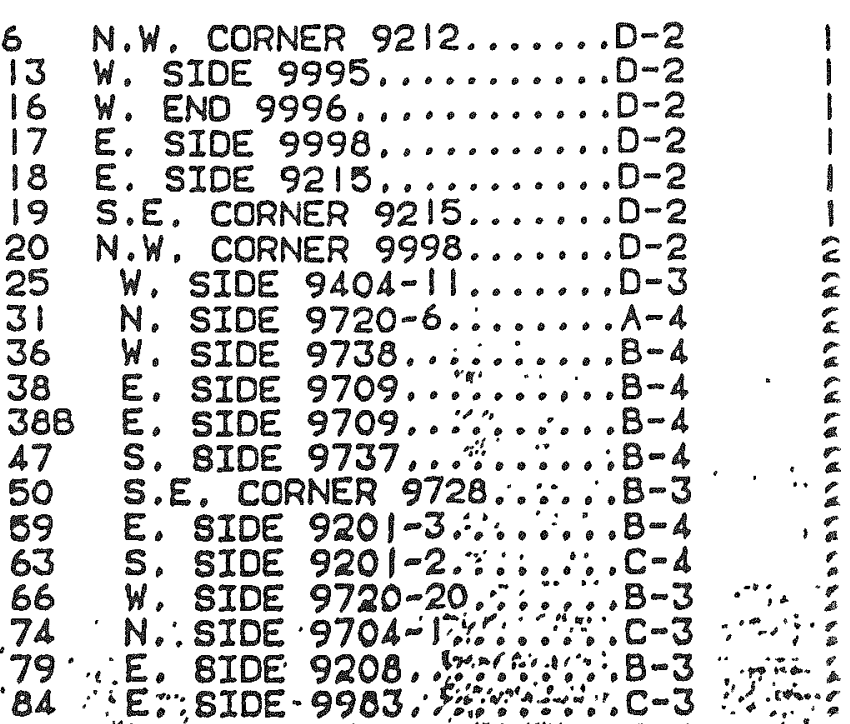

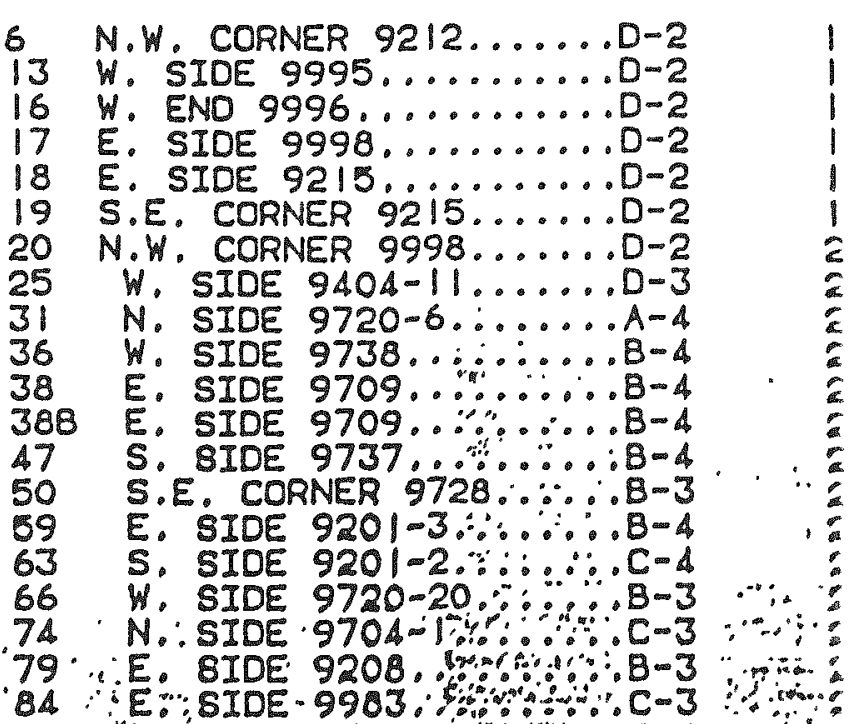

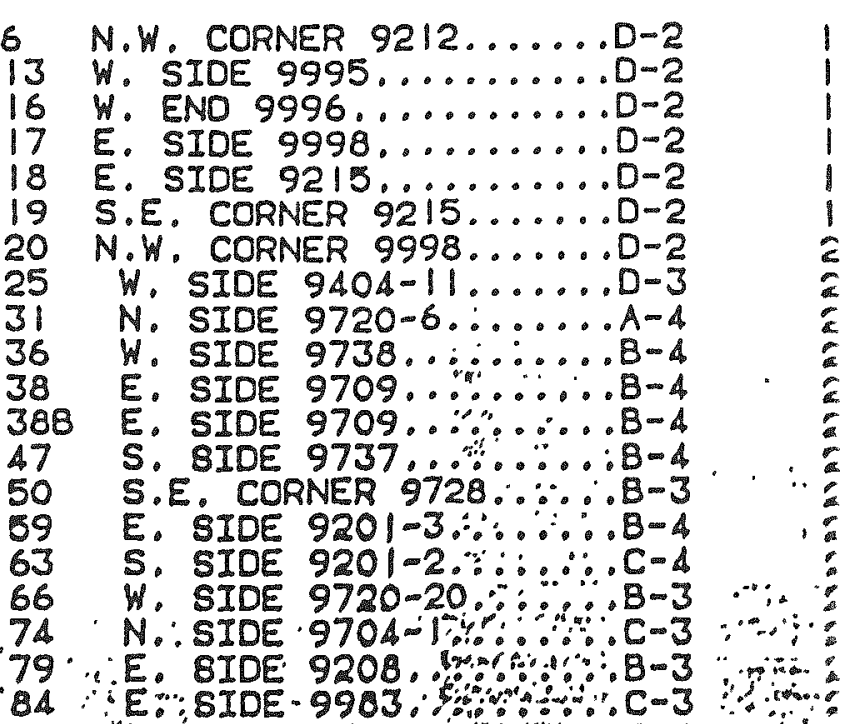

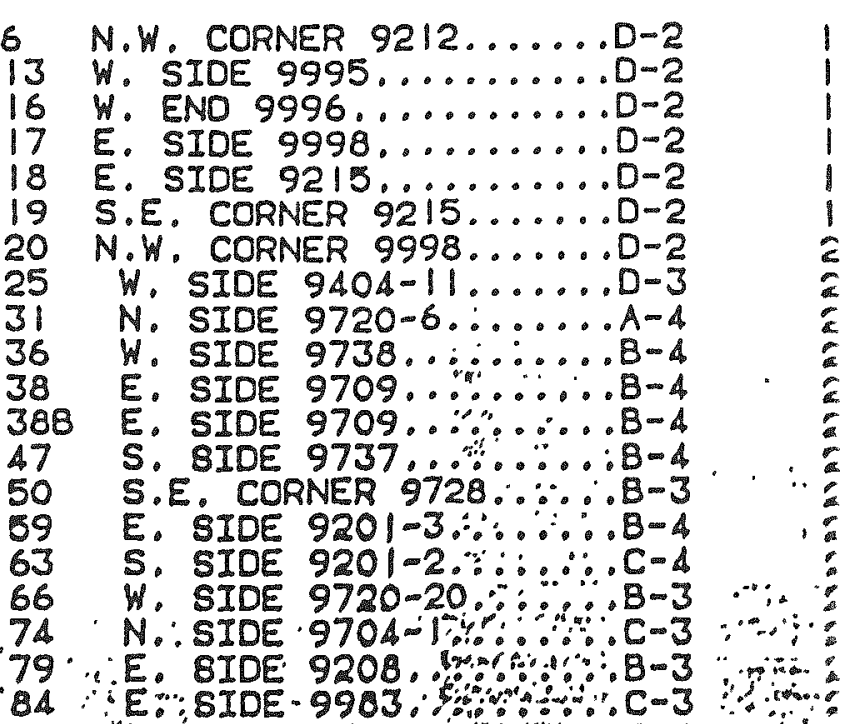

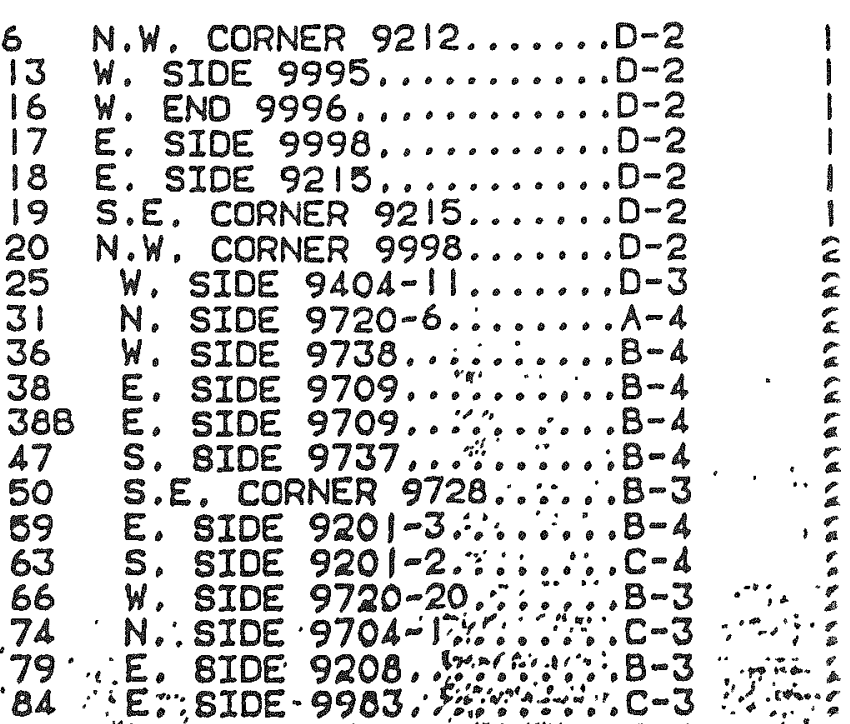

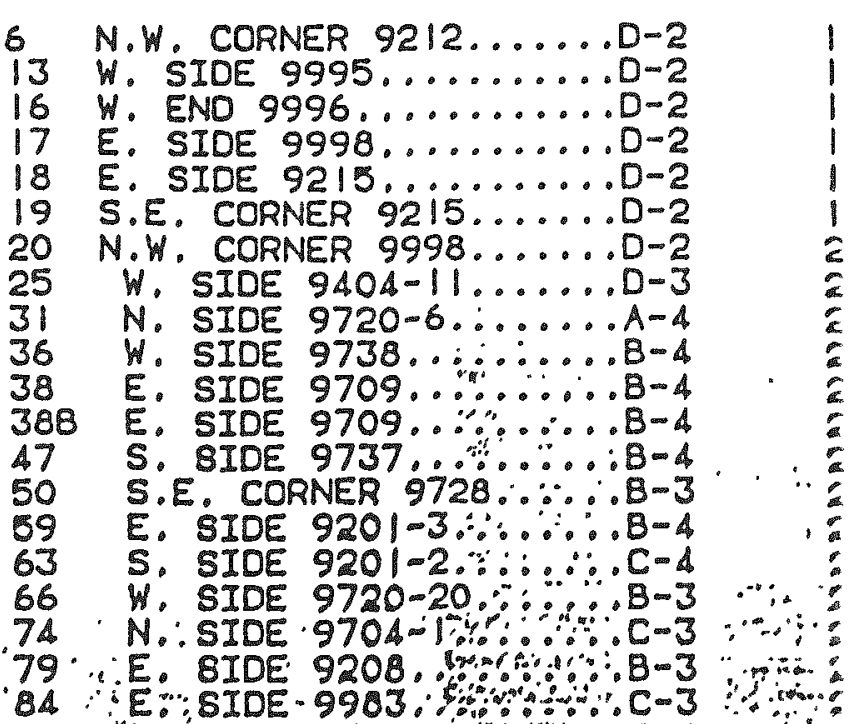

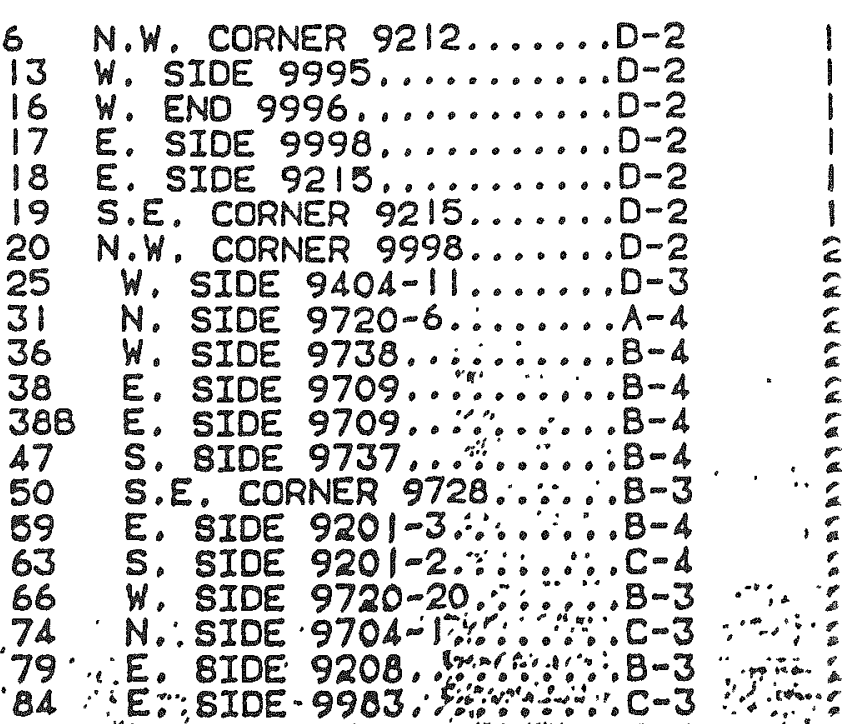

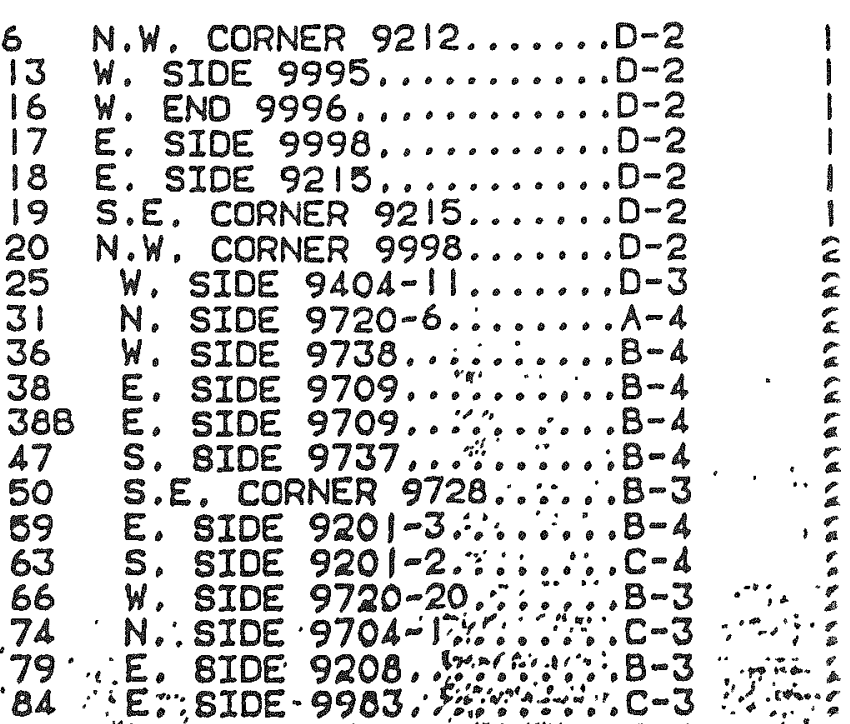

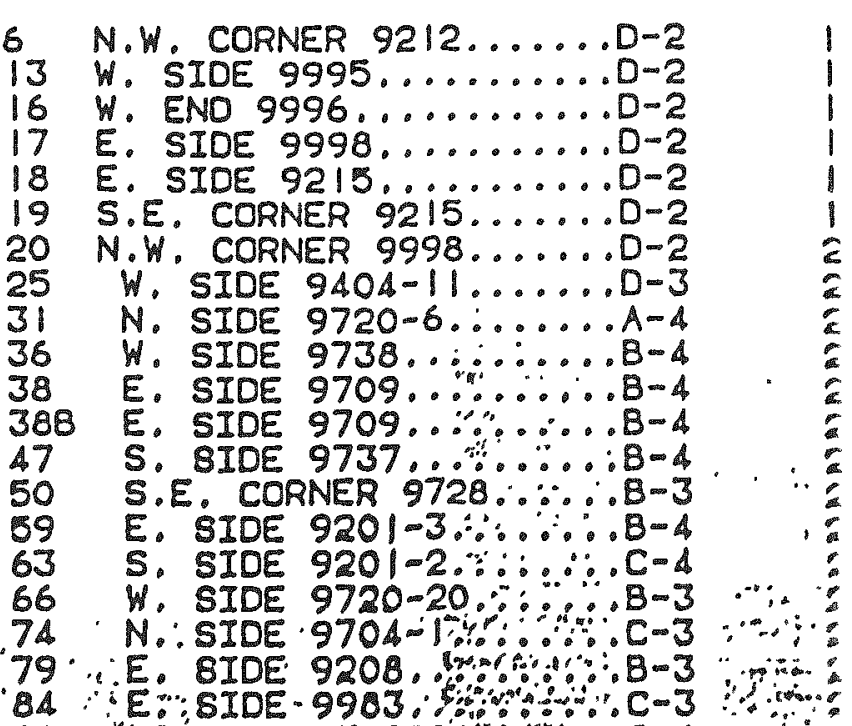

119 S.E. SIDE $9204 \div 1: \therefore-4$

$124:$ S. SIDE $9204-3 . \therefore \therefore D-4$

136 E. SIDE $9731 \therefore \ldots . .$.

139 S. SIDE $9711-5 \ldots \ldots . .$.

142 N.W. CORNER 9720-38..E-3

147 E. SIDE $9204-2 \ldots . . . D-3$

149 8. SIDE 9204-2.......

IBOA E. SIDE 97OA-2........ 


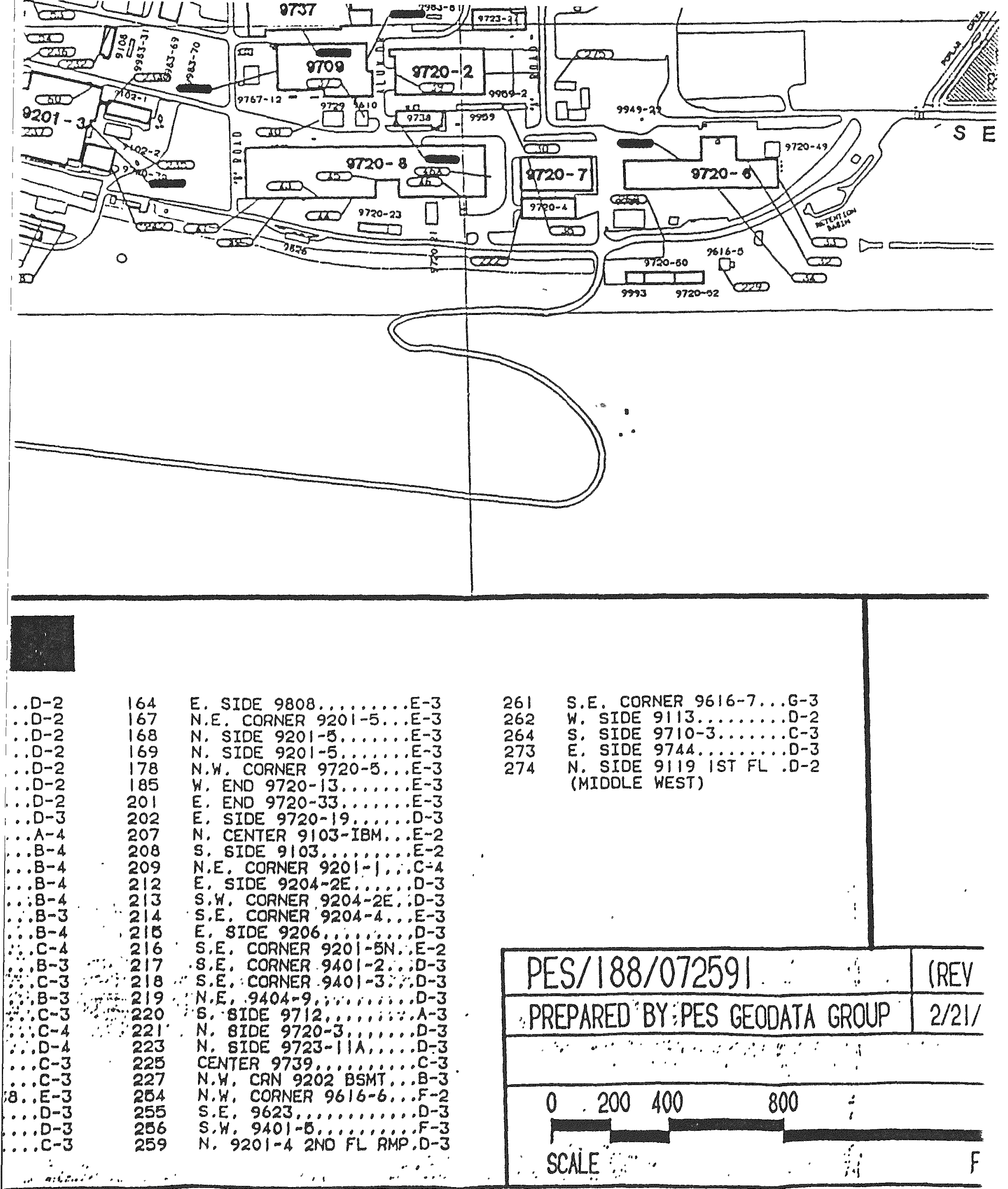

164 E. SIOE $9808 \ldots E-3$

167 N.E. CORNER $9201-5 \ldots$...

168 N. SIDE $9201-5 \ldots \ldots . . . E-3$

. SIDE $9720-19$.

N.E CORNER O20l- $l_{0} \cdot \mathrm{C}-4$

$E$. SIDE 9204-2E......D-3

SORNER 9204-2E:D-3

S.E. CORNER 9LOI $3 \cdots 00-3$

N.E, .9404-9, …...

5. SIDE $9712 \ldots . . \because A-3$

- 8IOE 9720-3.

CENTER 9739 .

N.H. CRN 9202 BSMT....-3

N. CORNER 9616-6,..5-2

$\cdots \cdots$
261

273

St $F[\cdot 0-2$ (MIDDLE WEST) 
(G)

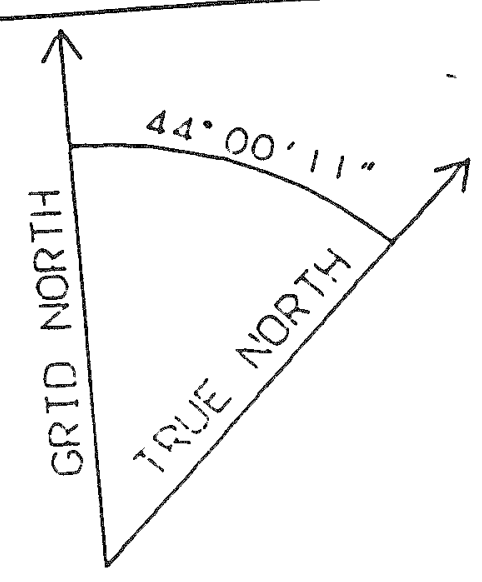

$R$
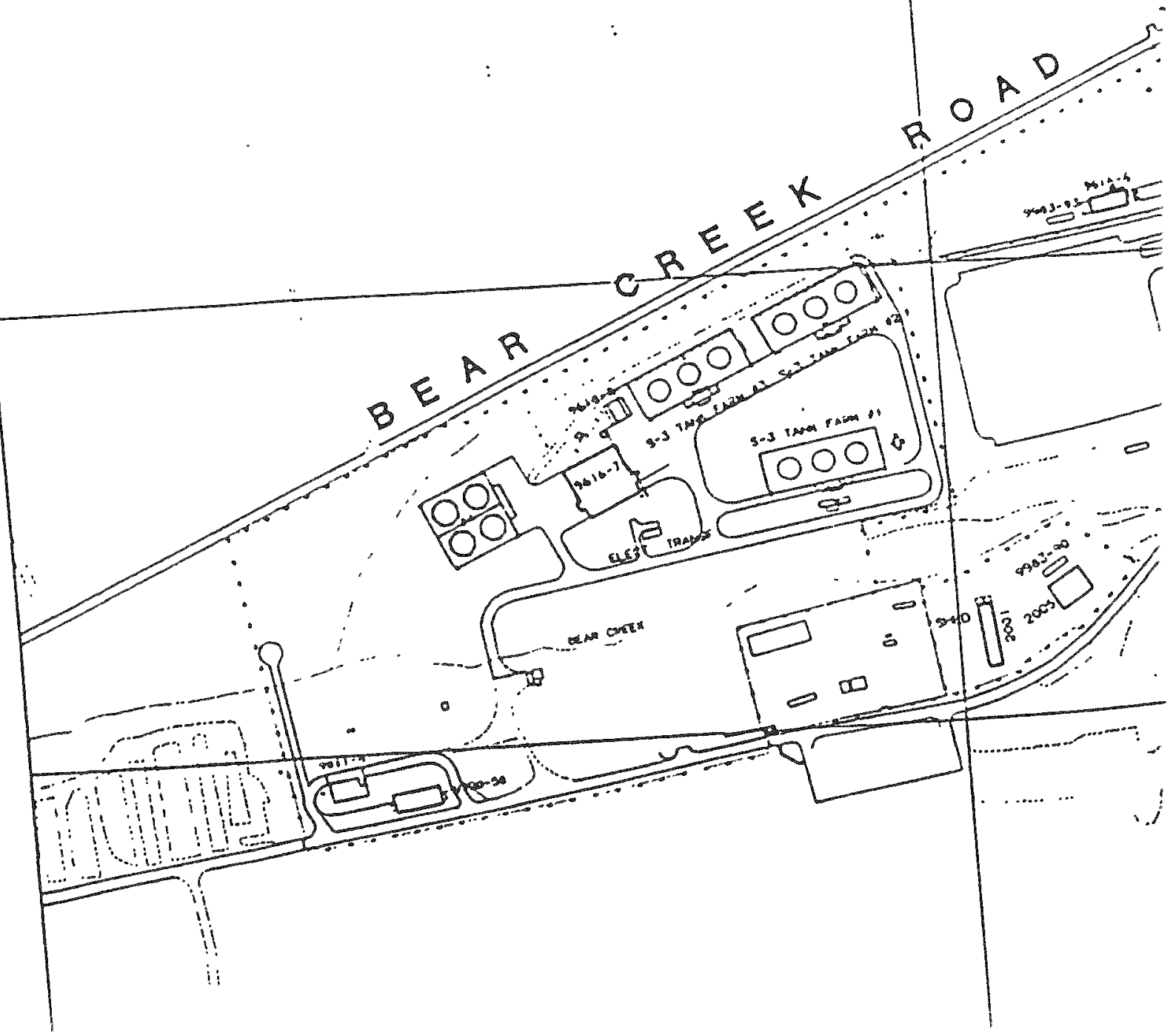

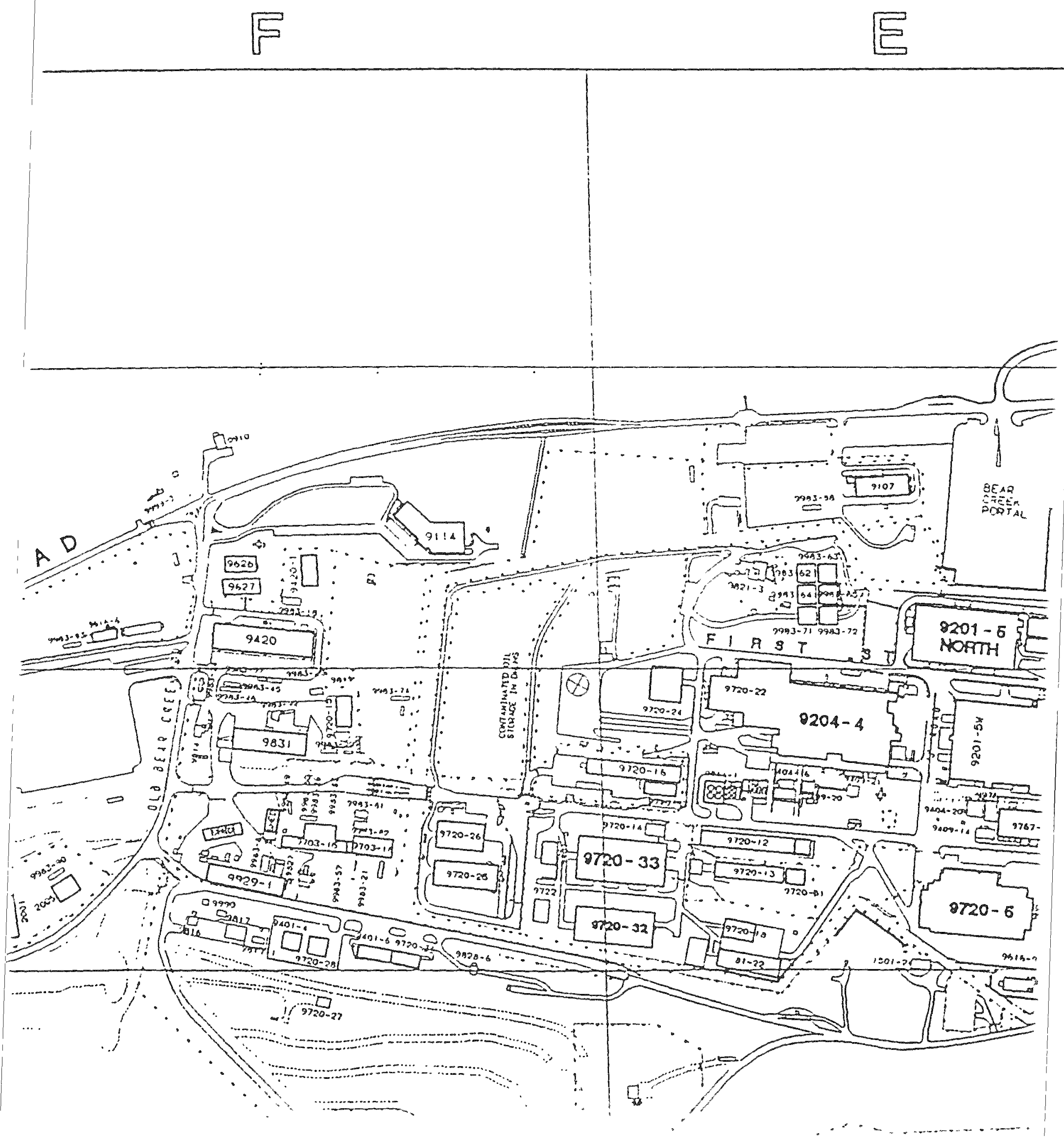


\section{$r-12$ FLUŨ}

(D)

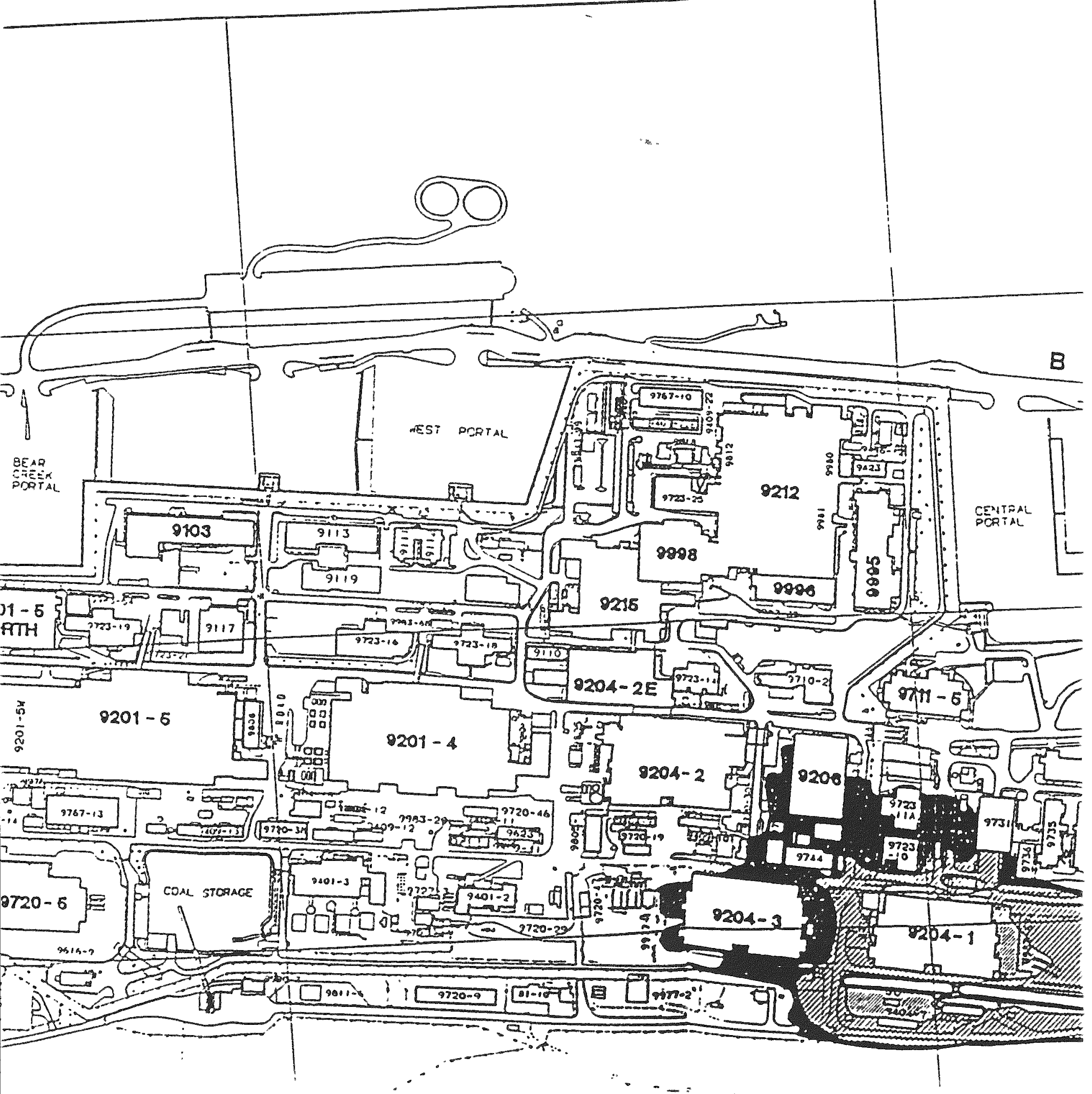




\section{$G$}

回

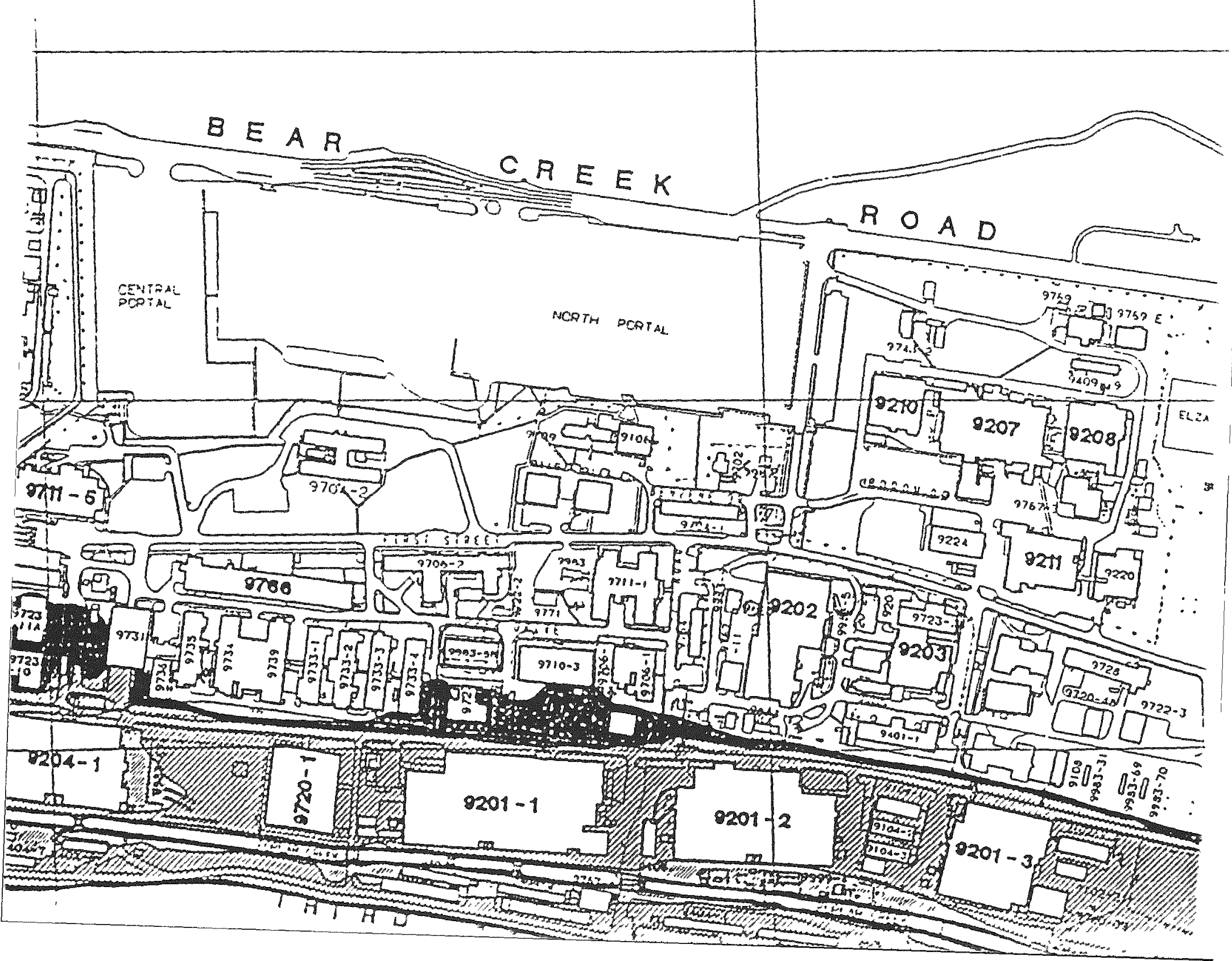




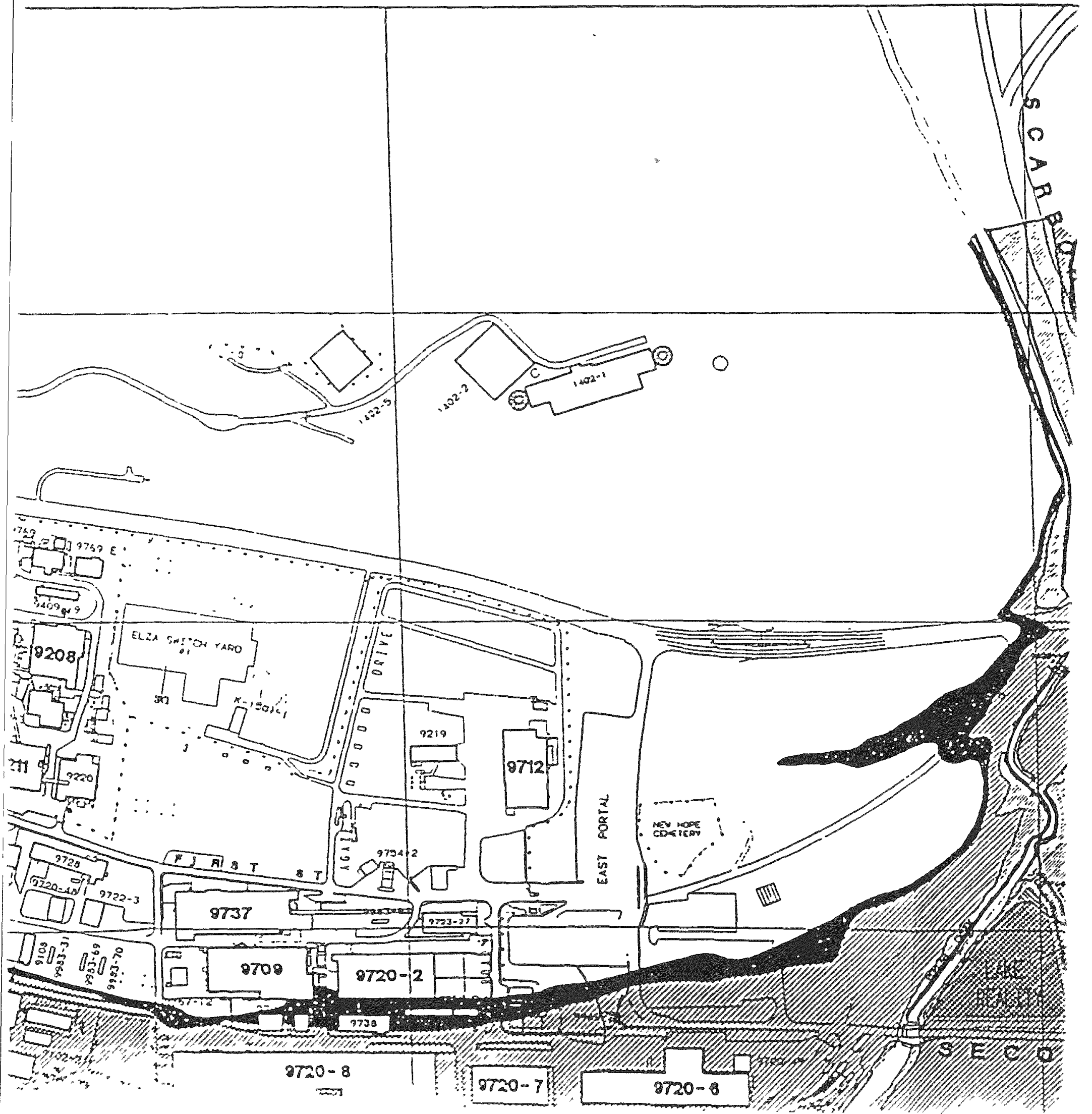




\section{AA}

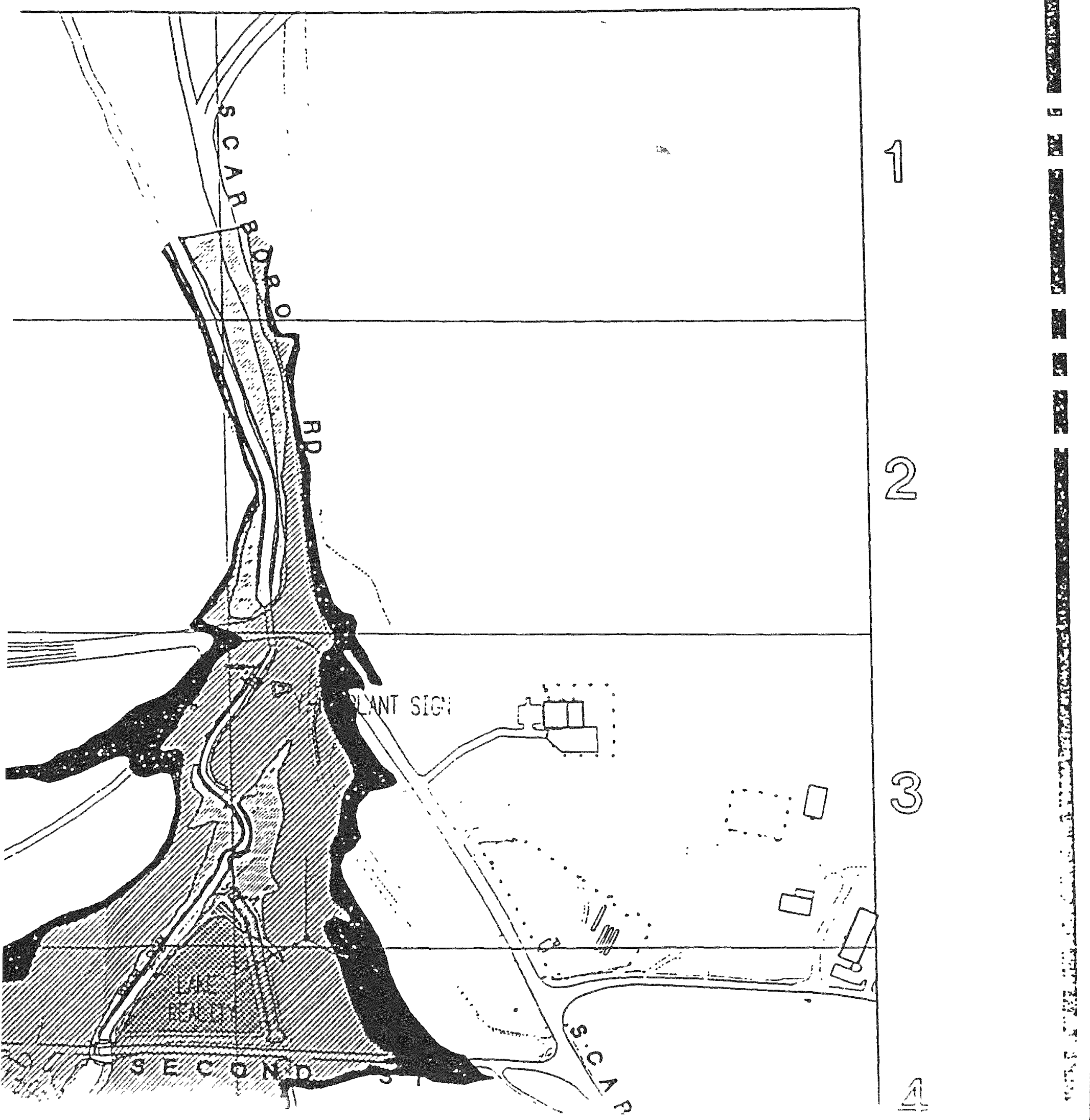




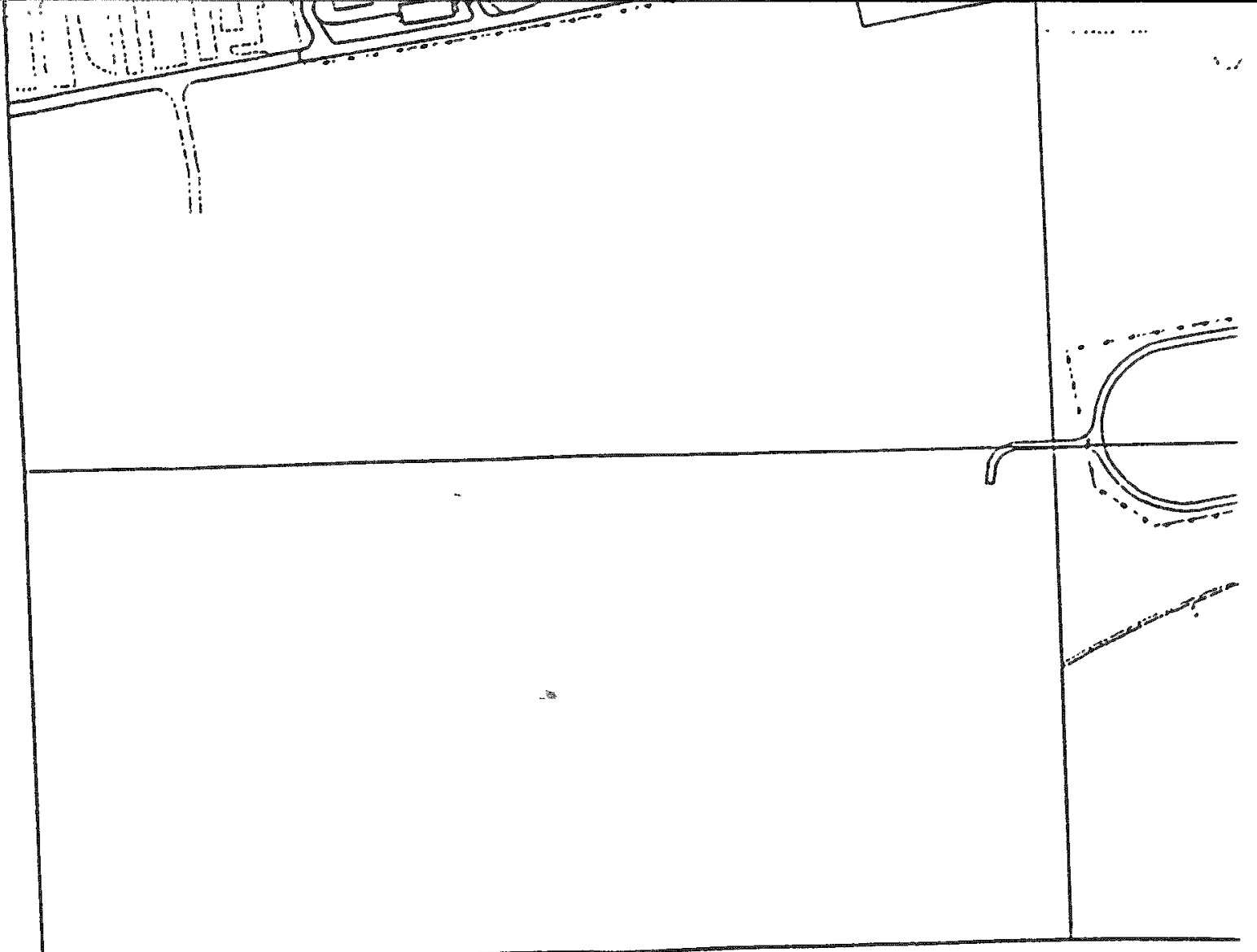

LEEEEND

PROBABLE MAXIM.

MAXIMUM PROBAE

500 YEAR FLOO

100 YEAR FLOOI 


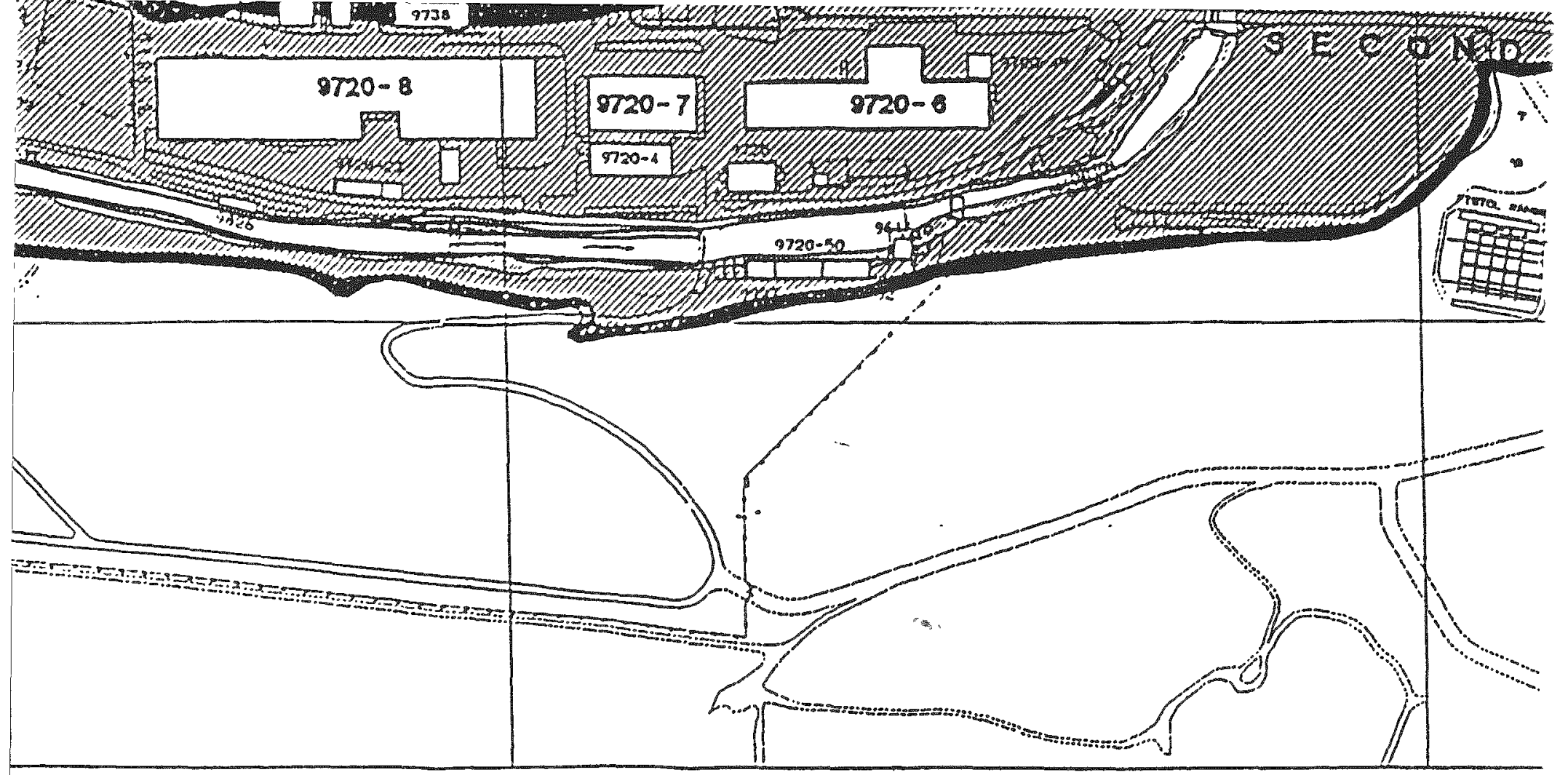

WLERTW MLARUETRA ENEAOY SYSTE DOE FIELO OFFICES, OAK RIOGE, TENNESSEE - PADUCAH

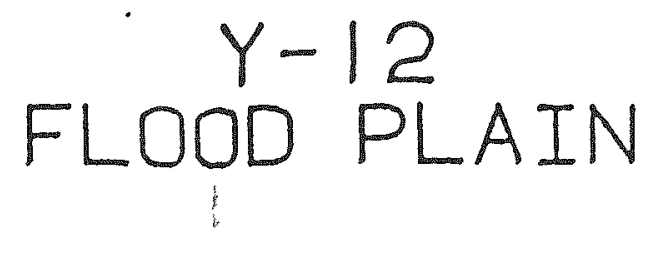




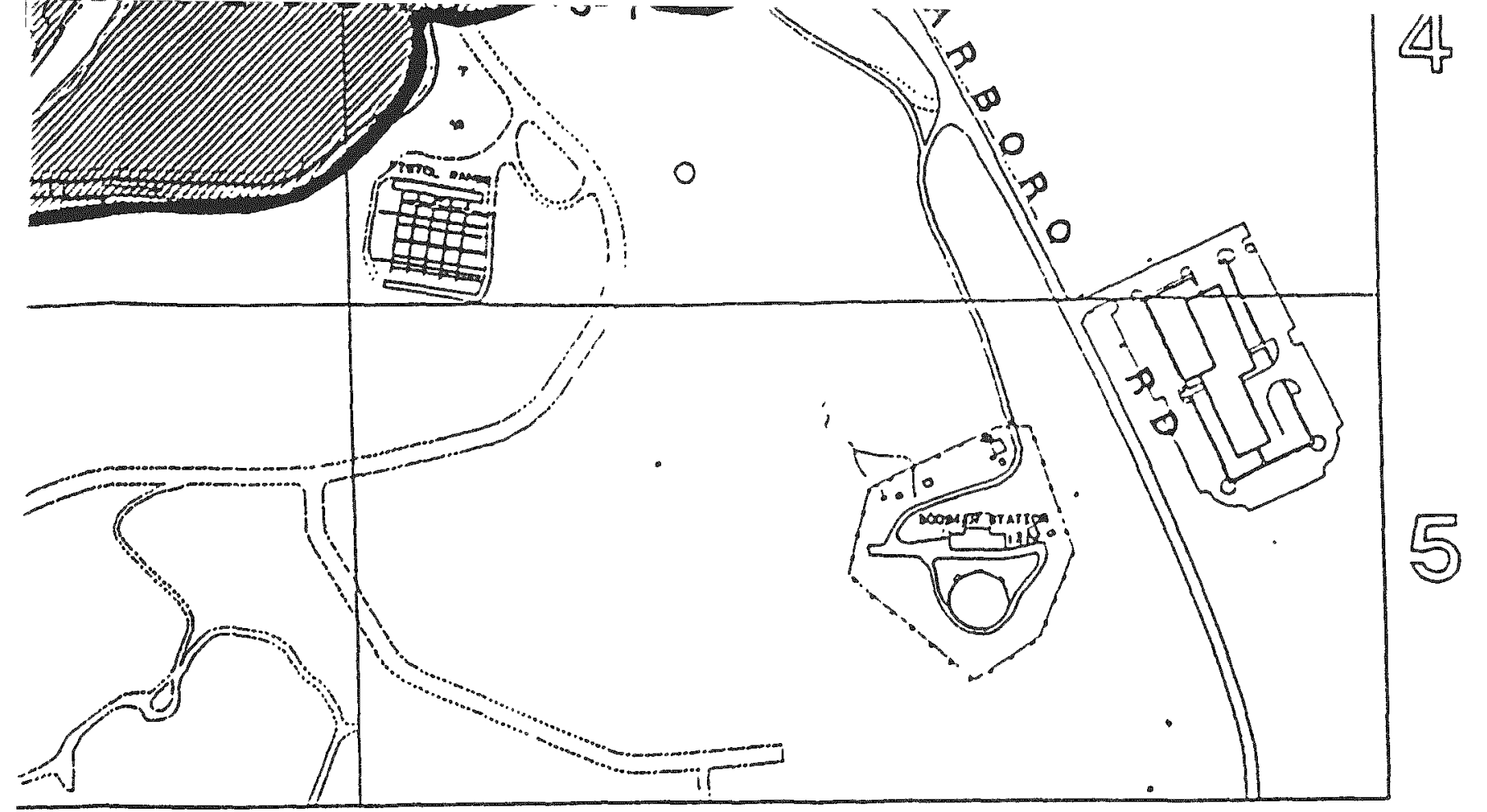

\begin{tabular}{|c|c|c|c|}
\hline DVETRA ENEROY SYSTEM8, INC. & PES/061/02 & & (REV \\
\hline AK RIDGE, TENNESSEE - PAOUCAH, KENTUCKY & PREPARED BY & S GEODATA & GROUP \\
\hline $\begin{array}{c}Y-12 \\
.000 \text { PLAIN }\end{array}$ & SCALE $=0$ & $\underbrace{\circ}_{600}$ & $\begin{array}{l}1200 \\
\end{array}$ \\
\hline
\end{tabular}




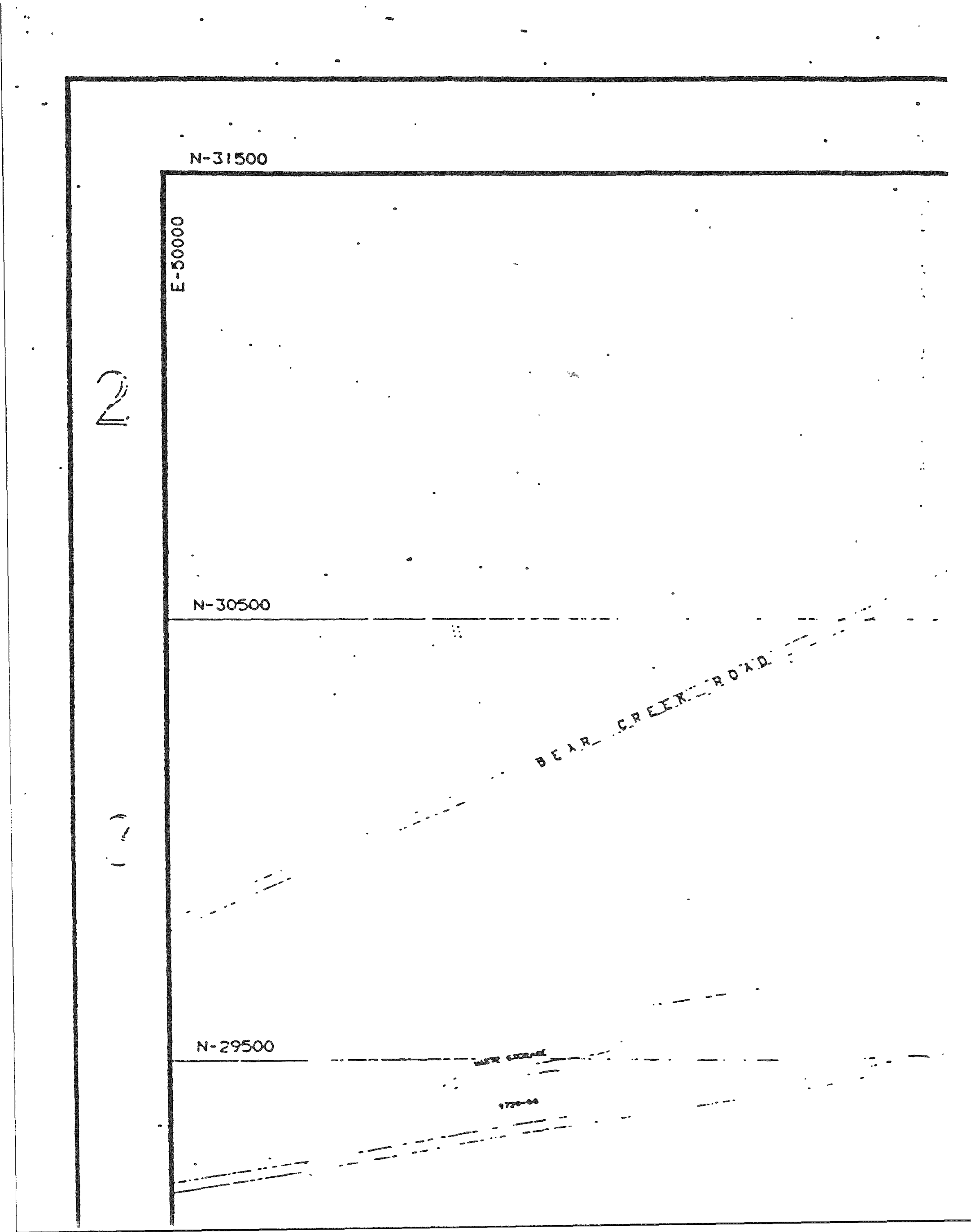




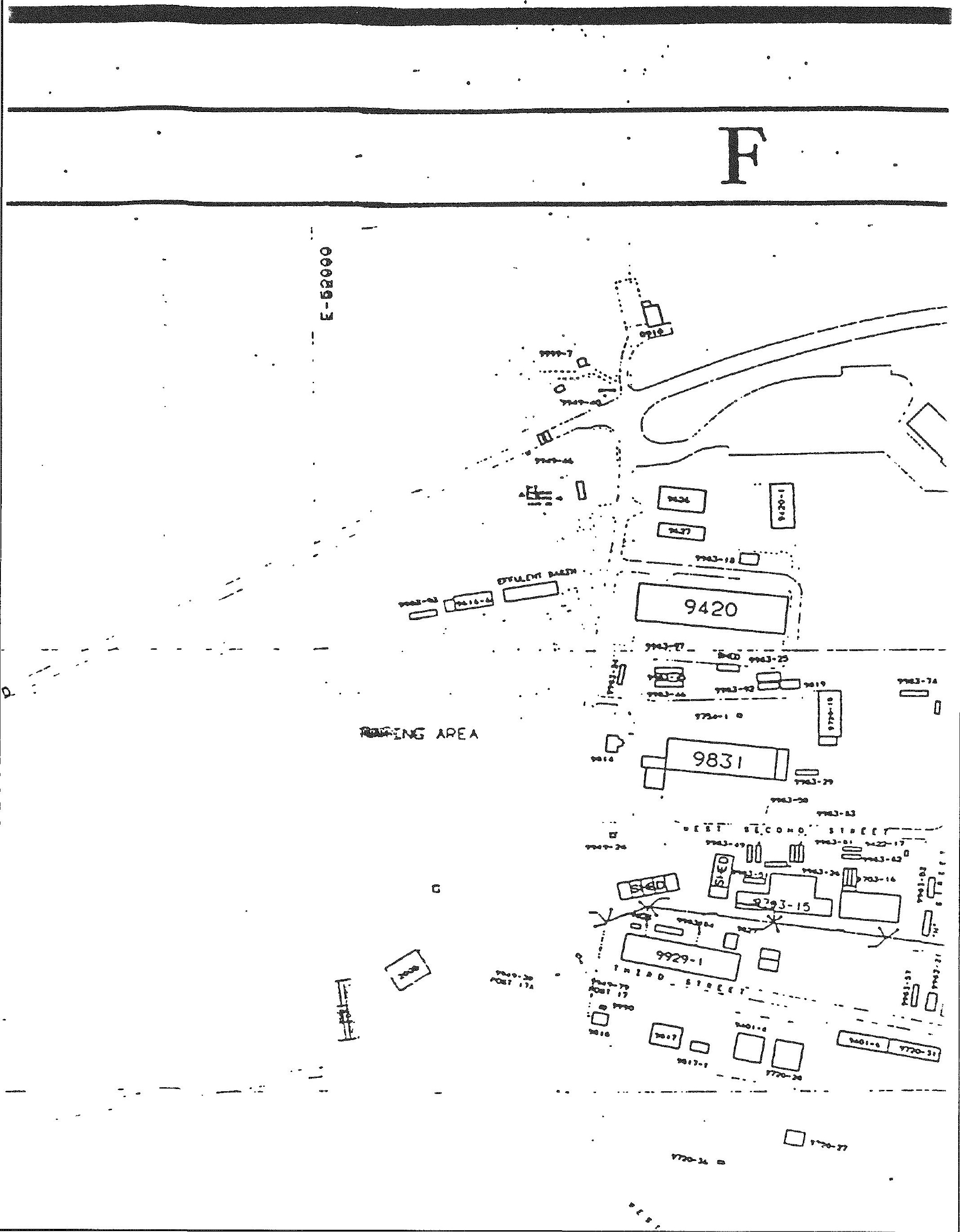




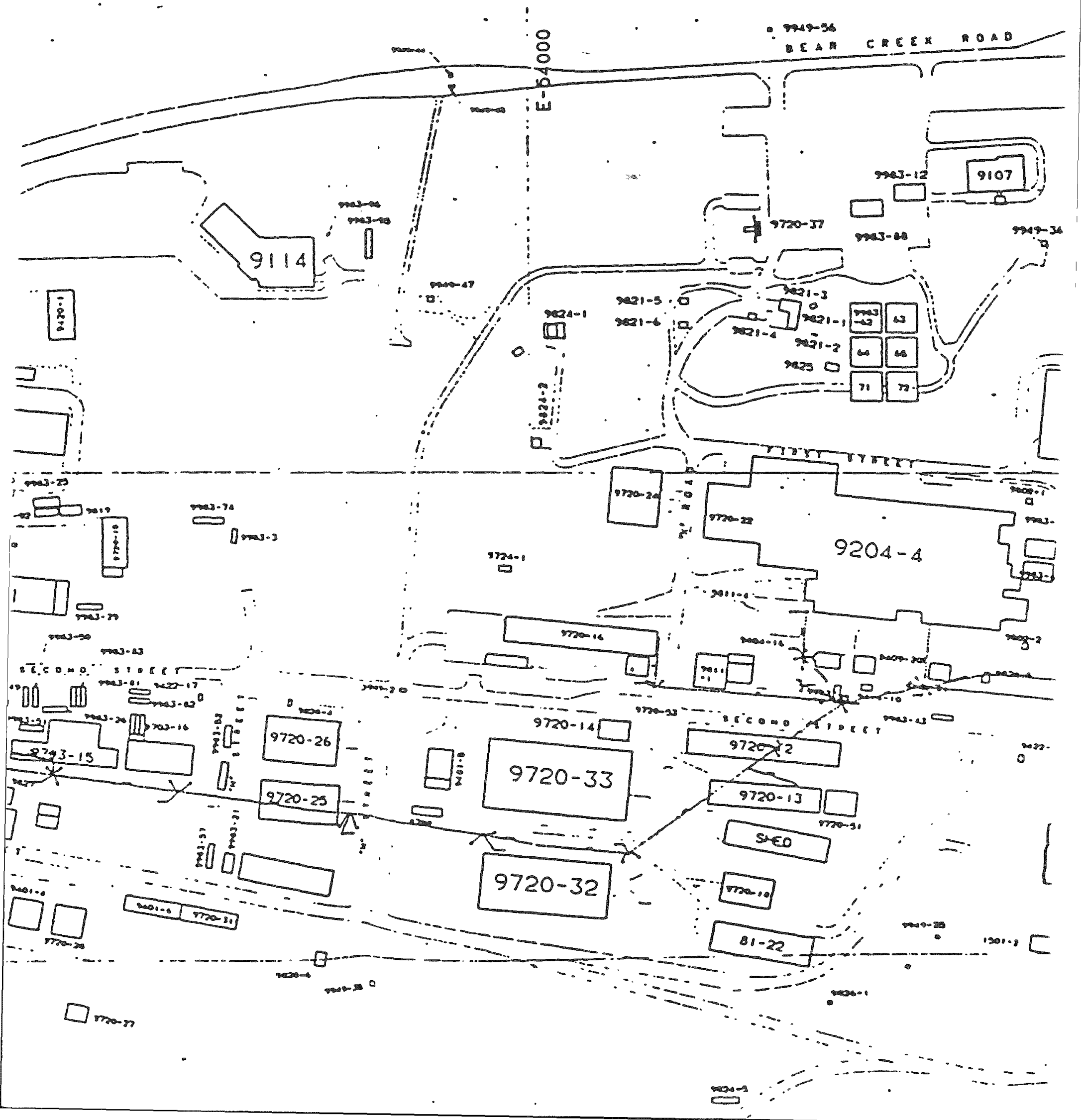


$\mathrm{E}$

ด 0

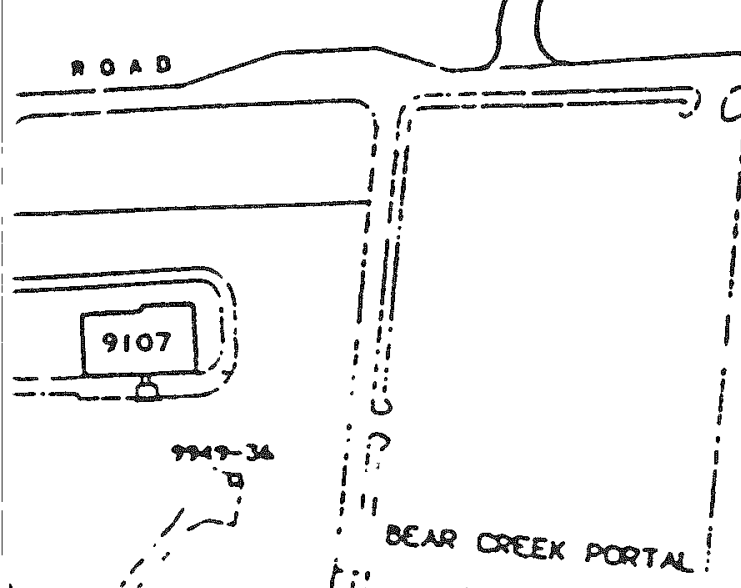

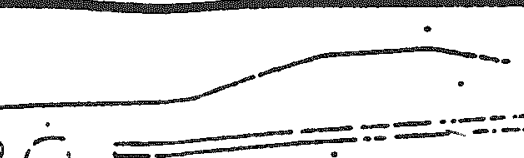

$5=8$

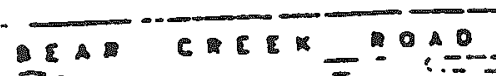
if

1

MEST PORTA.
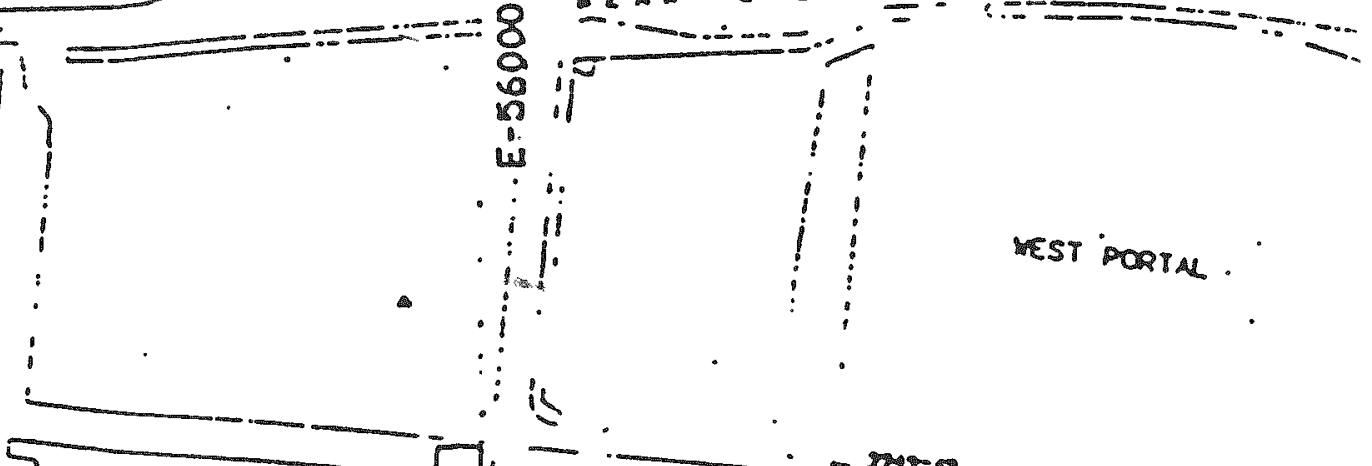

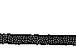
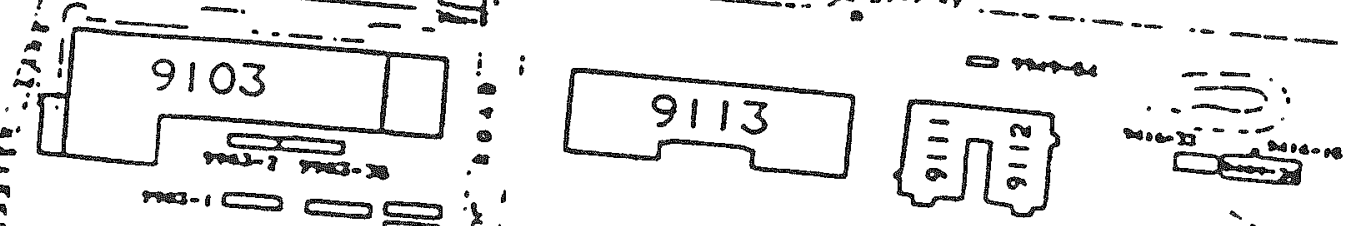

?
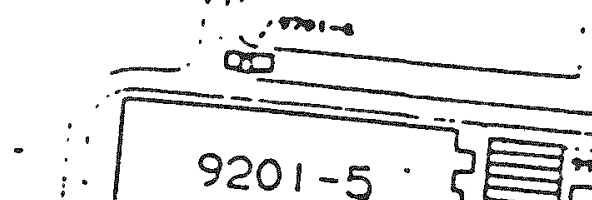

$\therefore$

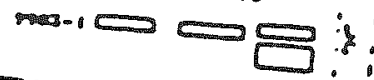

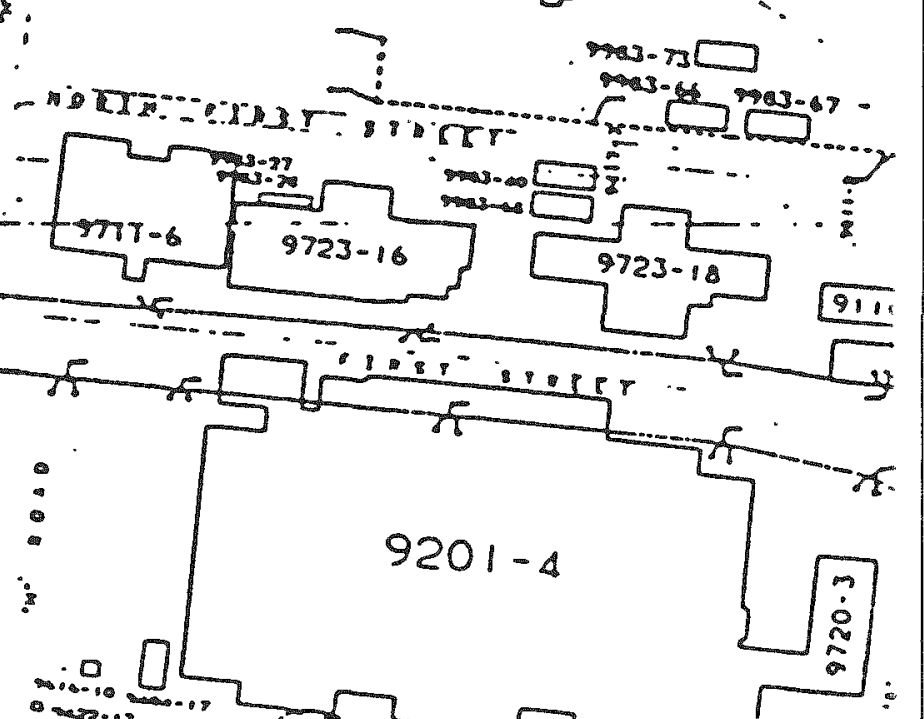

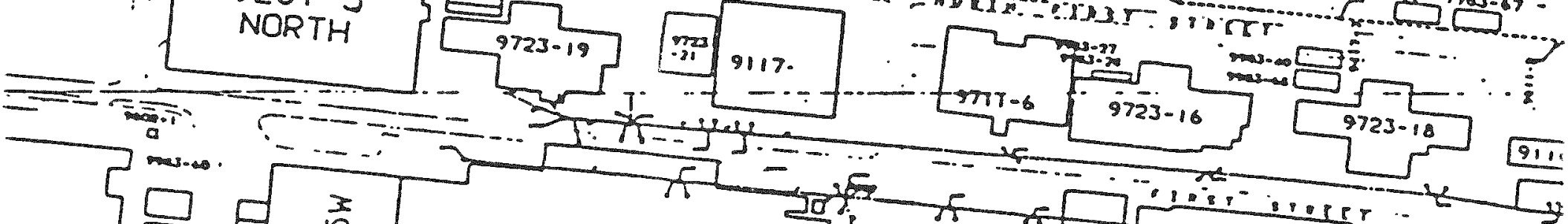

$\sum_{3}\left\{\begin{array}{c}\frac{1}{1} \\ \frac{1}{3} \\ a\end{array} \quad 9201-5\right.$

$\int_{x \rightarrow 0.3}$

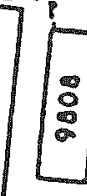

$\square$

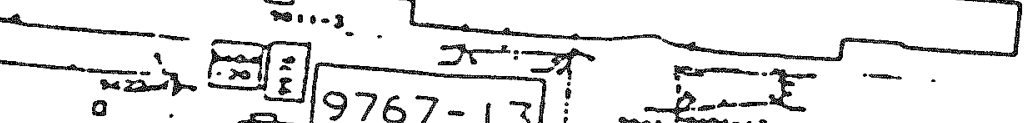

ن

¿

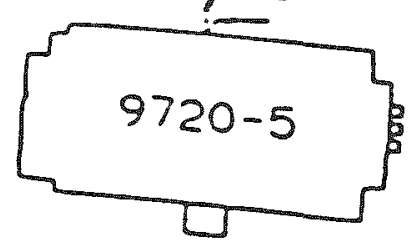

कर $\frac{909-13}{8}$

[9720-30]

20.8. 30

DON STOOACE AREA
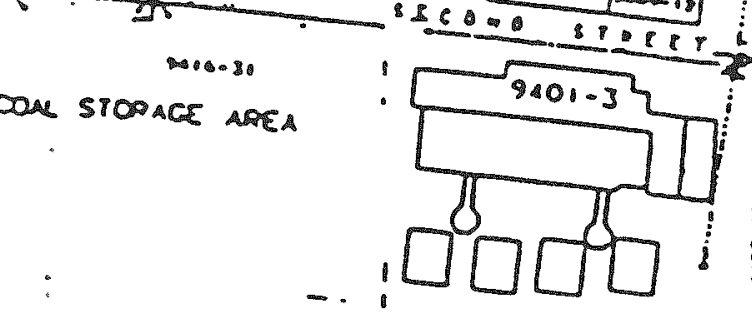

1500.8

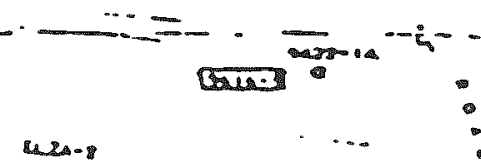

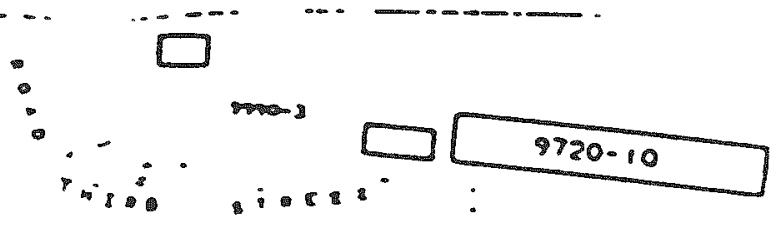

$=\frac{100}{9001-2]}$

.. - . .

-1...

$1878-4$

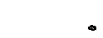




\section{D}

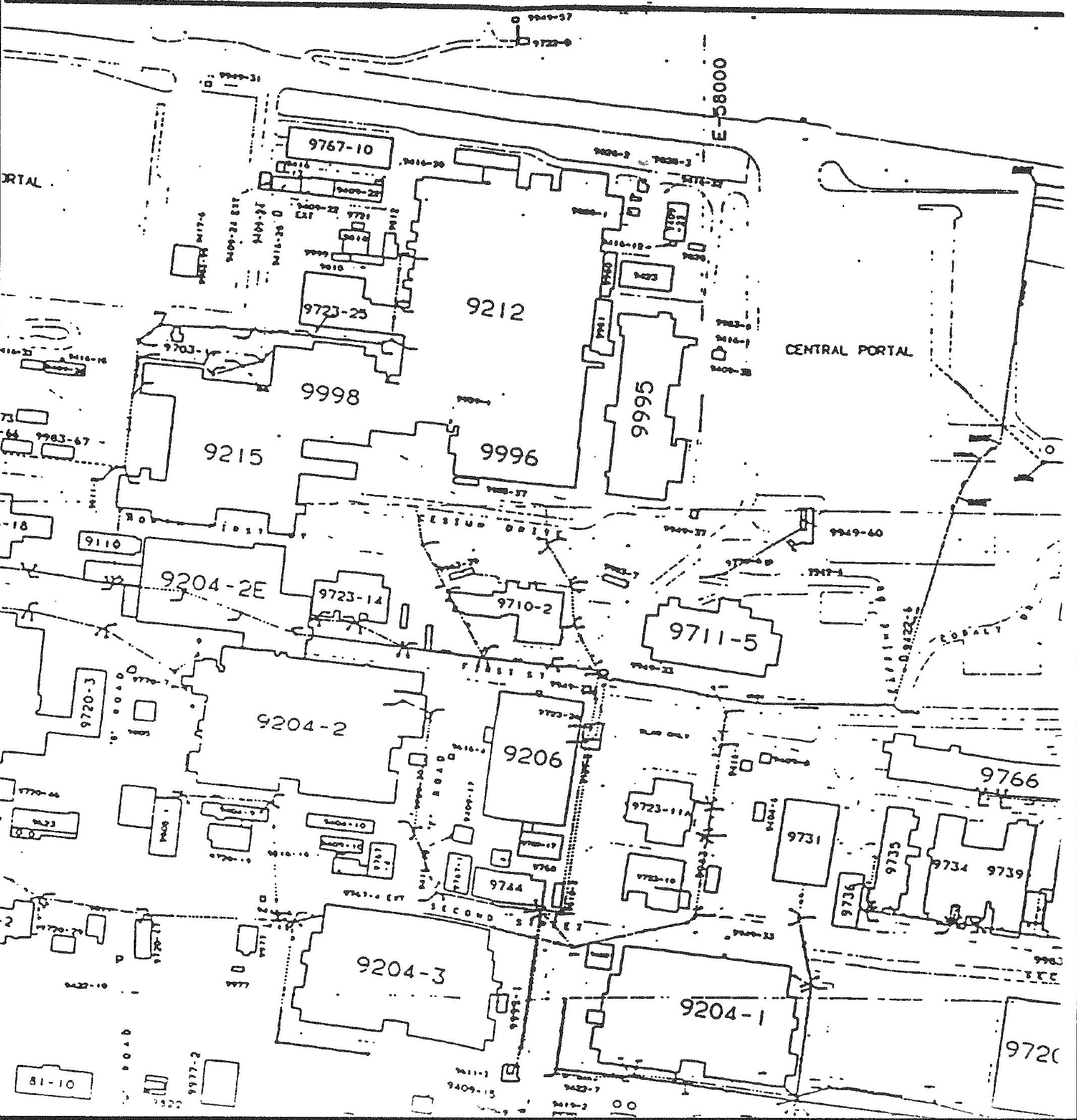




\section{B .}

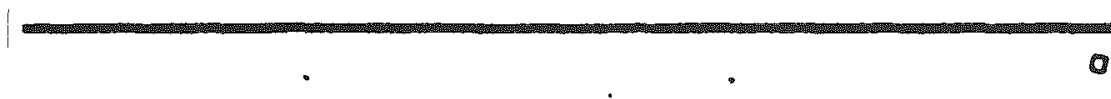




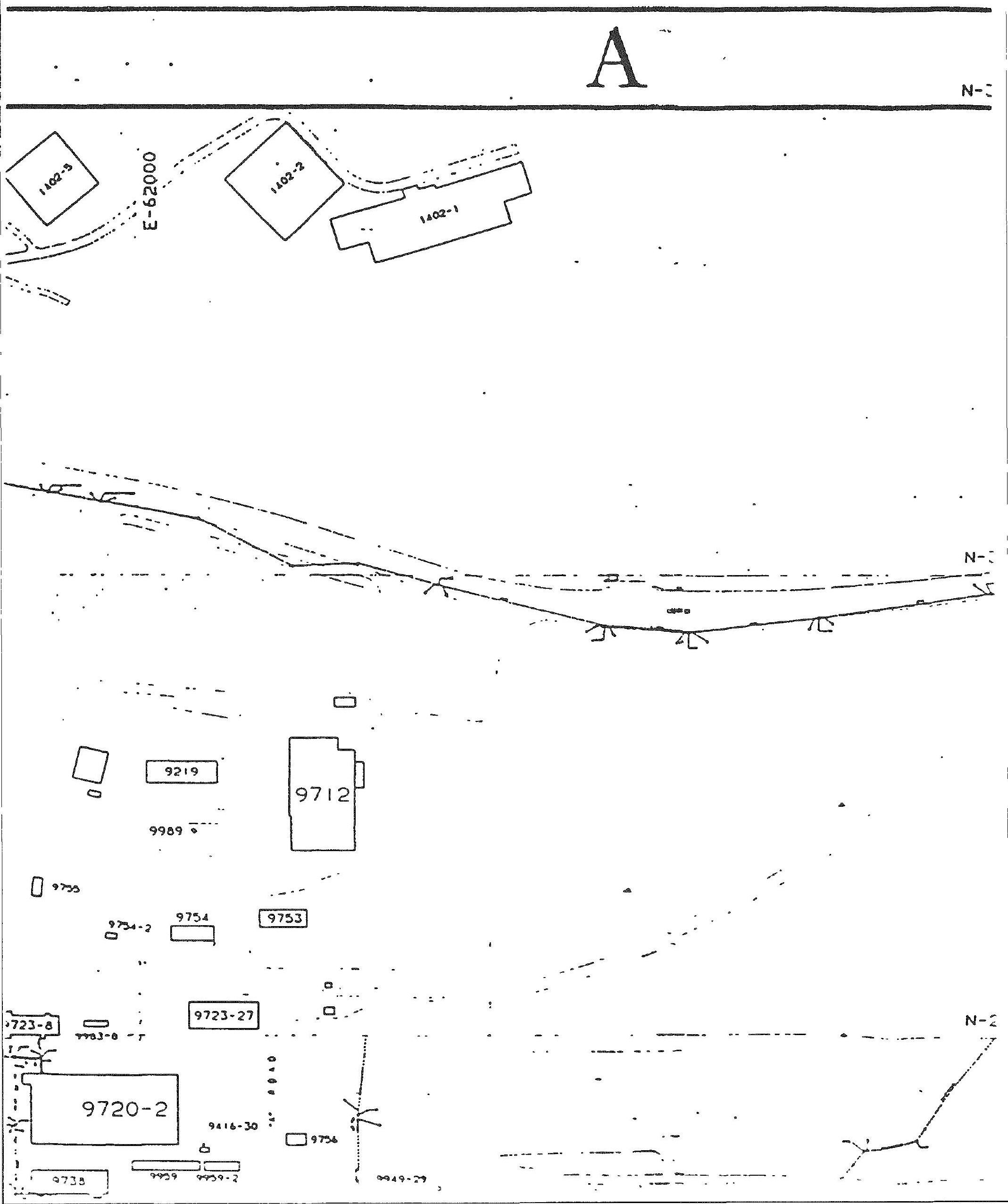




\section{$\tan t \pi \cdot$}

$N-31500$

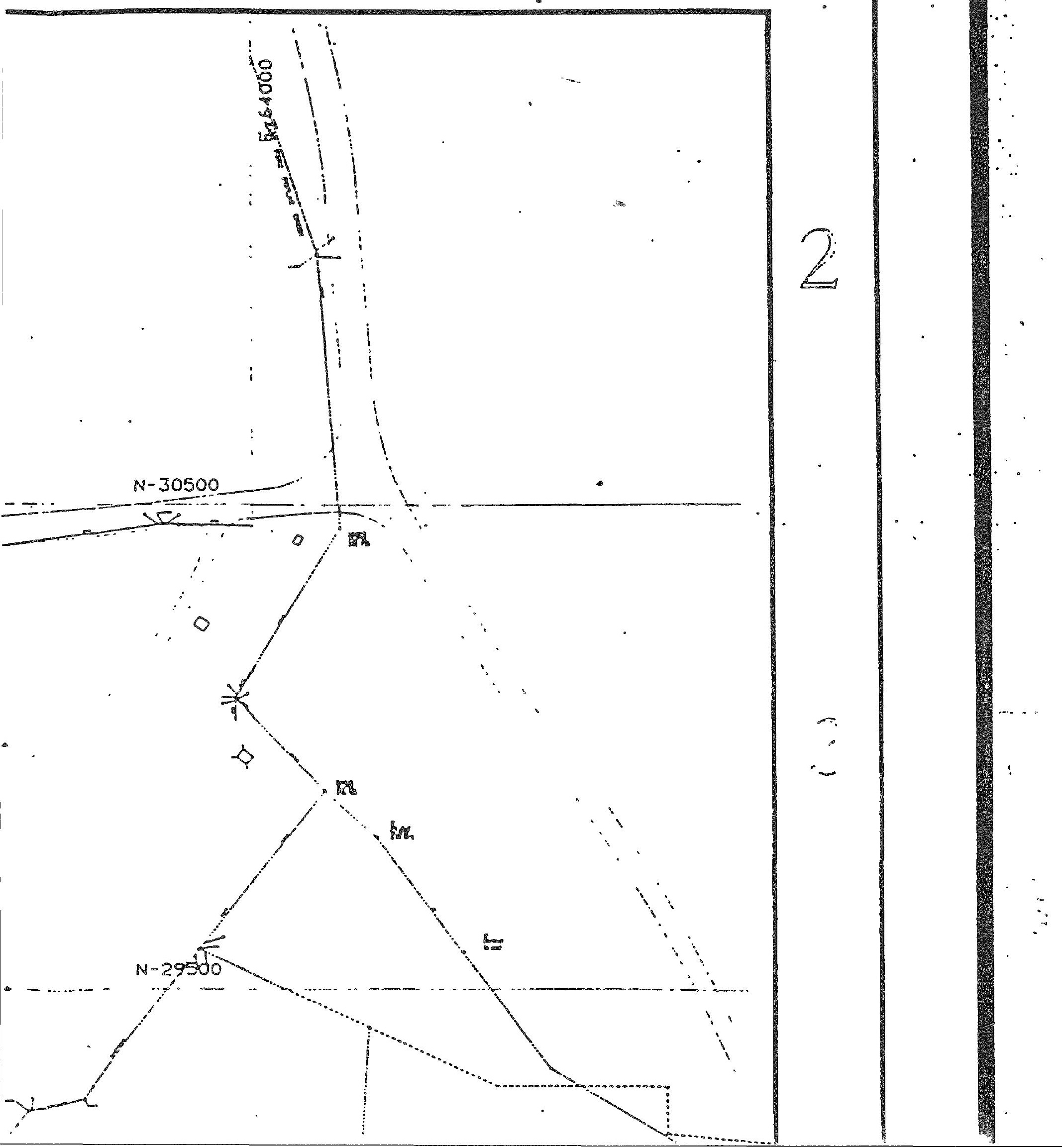




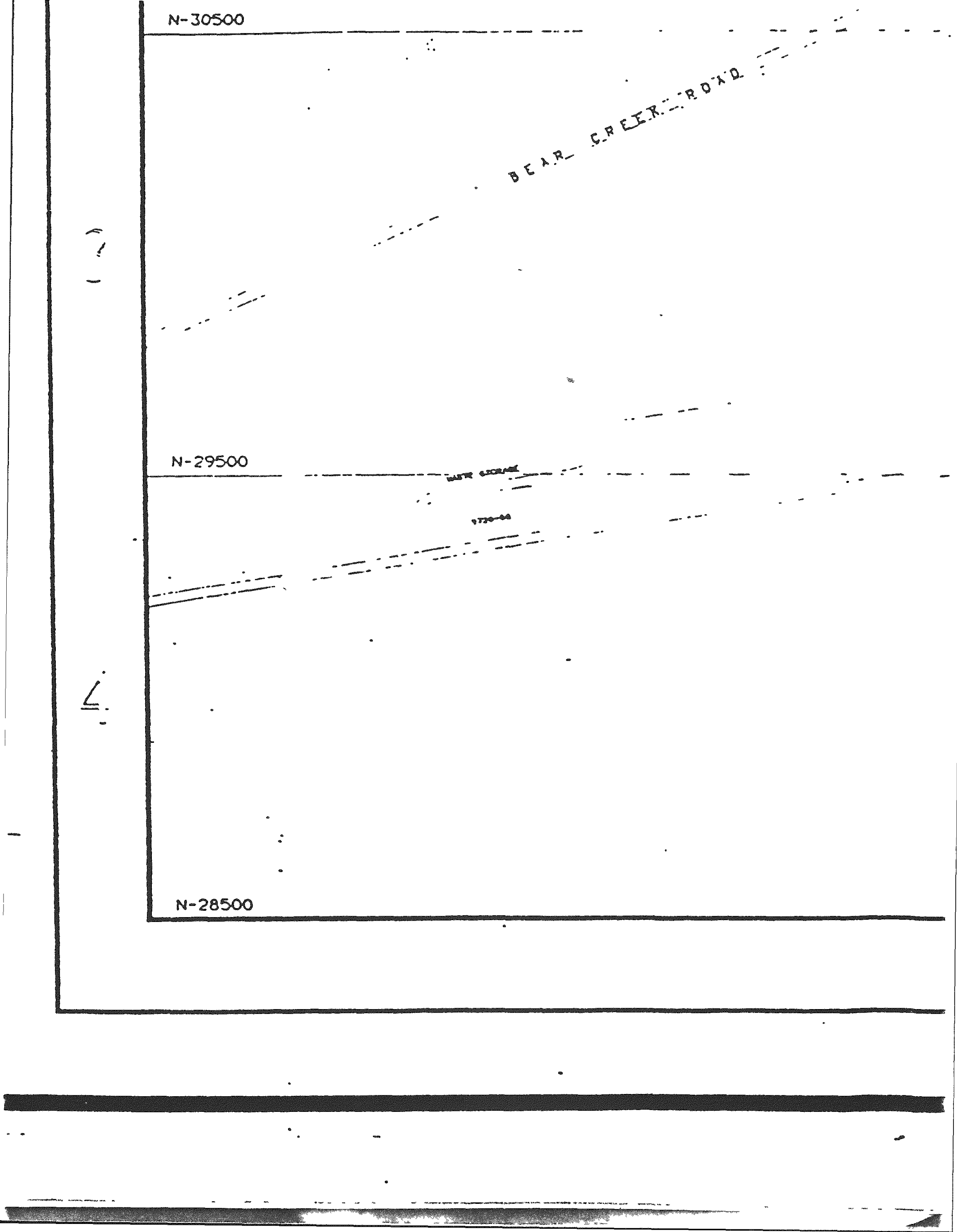


RATING $A D E A$

画

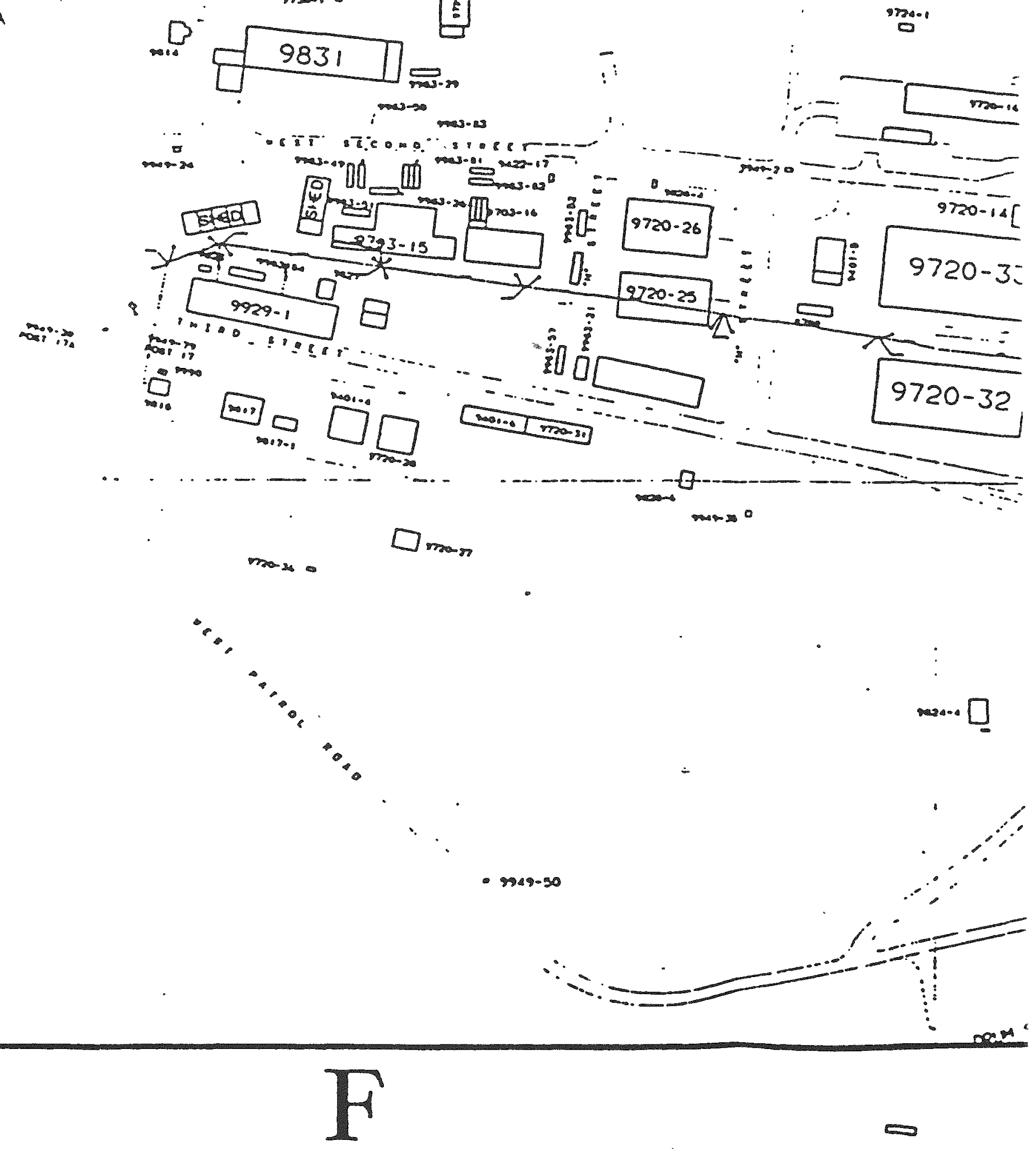




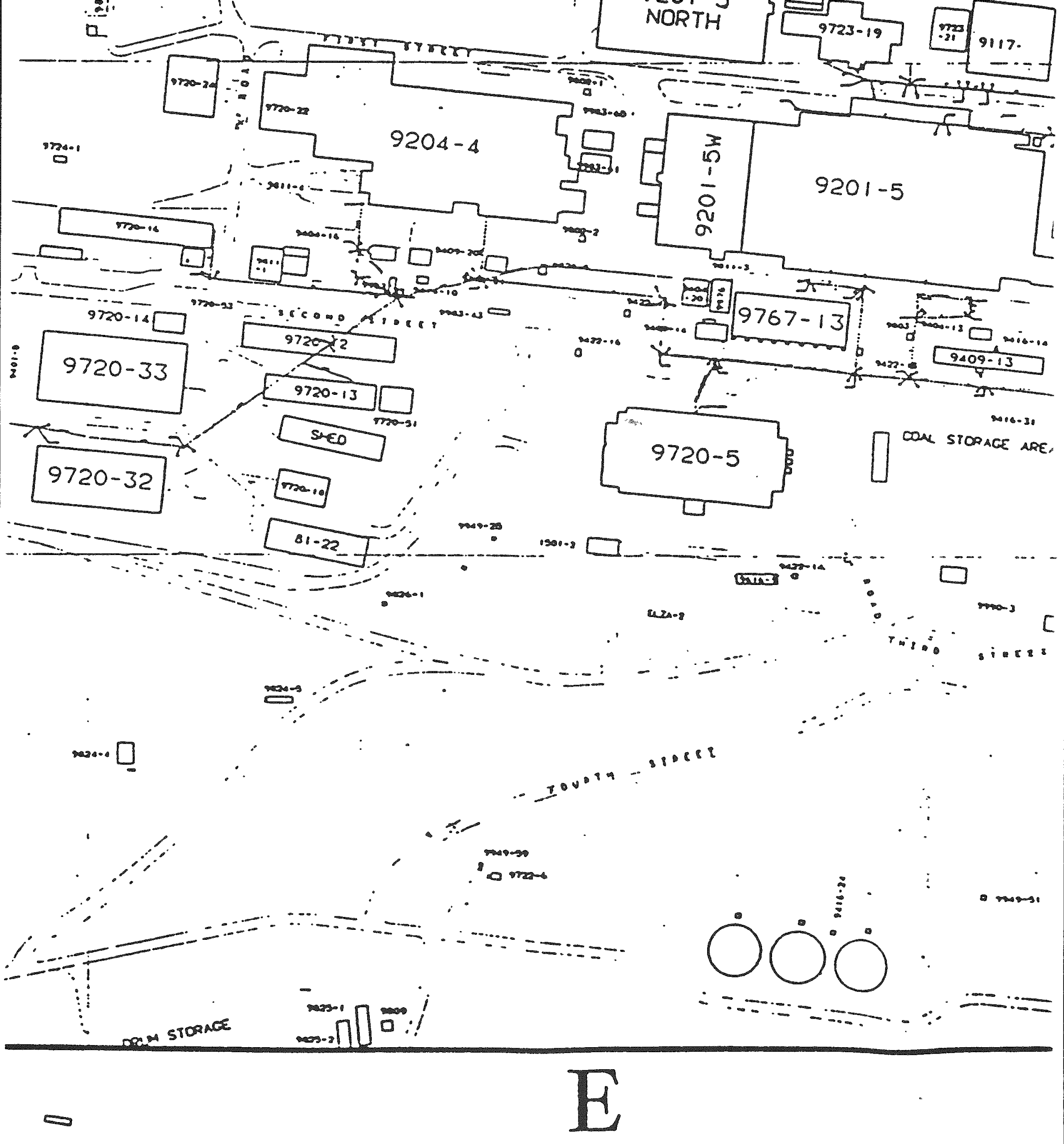



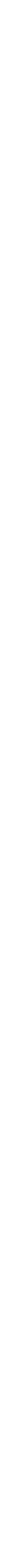

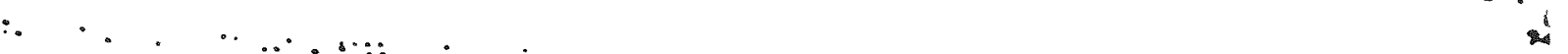

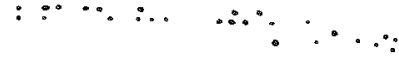




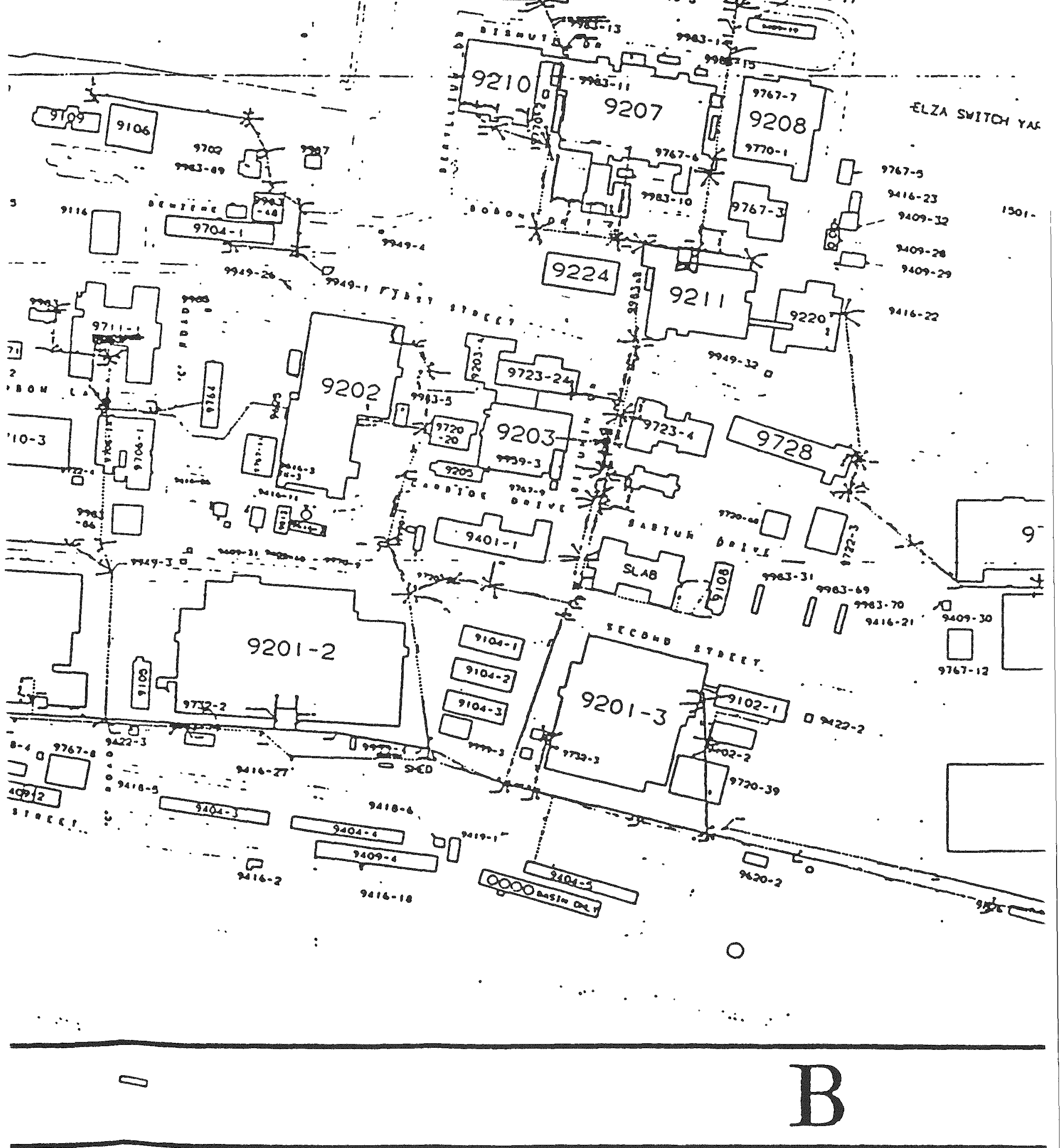




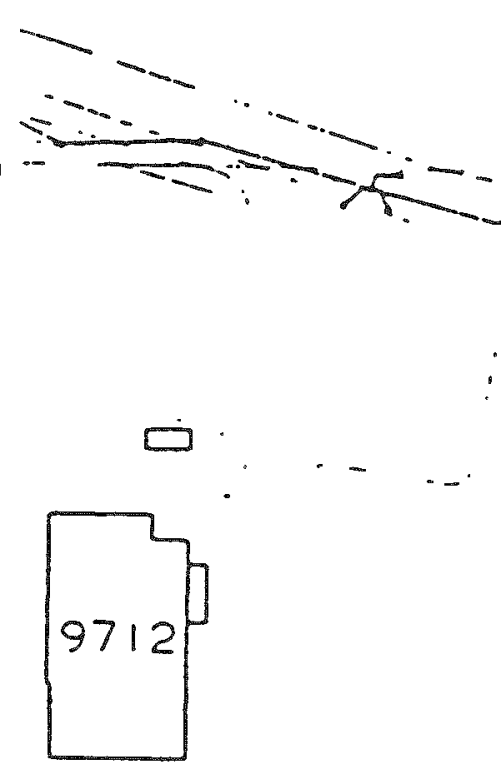




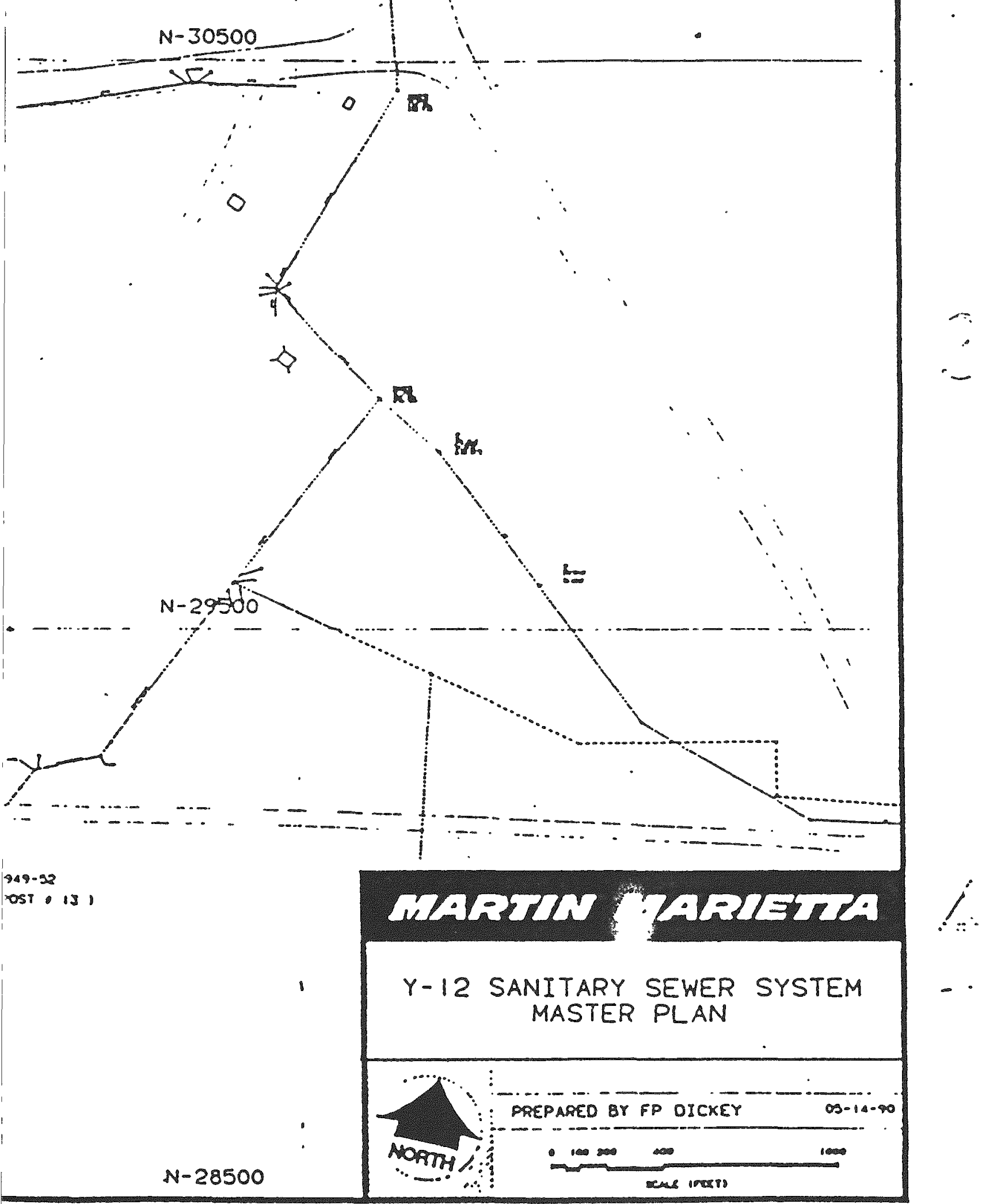




\section{Map 6}

\section{The Y-12 Plant Storm Sewer System Master Plan Map}

The Y-12 Plant Storm Sewer System Master Plan Map has been determined by the U.S. Department of Energy to contain UNCLASSIFIED CONTROLLED NUCLEAR INFORMATION (UCNI) and is not to be disseminated to the public. The document must be protected as required in $10 \mathrm{CFR}$ Part 1017 and its implementing orders. Unauthorized dissemination of the material is subject to civil and criminal sanctions under section 148 of the Atomic Energy Act of 1954, as amended (42 U.S.C. 2168).

The Y-12 Plant Storm Sewer System Master Plan Map was submitted as a part of the first revision of this document. If additional copies of this map are needed, please contact C. M. LaBorde at (615) 576-5603. 


\title{
TENNESSEE DEPARTMENT OF CONSERVATION
}

\author{
Cuscoms house \\ 701 Broadwey \\ Nastivile, IN 37243
}

October 24, 1991

Moberaj. Sperce

I-12 S1te Mamer

Departaent of Energ

P.0. BOF 2001

Oak Ridge, IN $37831-8555$

EE: Revource Conservation and Recovery Act Part I Perint Maps

Dear Mr. Spence:

The Division of Solld Wasce Mngement is in recelpe of your Uctober 9, 1991, lercer requestag a vardance from the mapping scales required in Rule 1200-1-

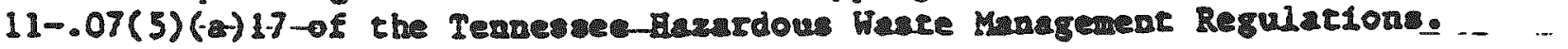

Due to the nature of the Department of Energy Reservation at Onk Ildge, the

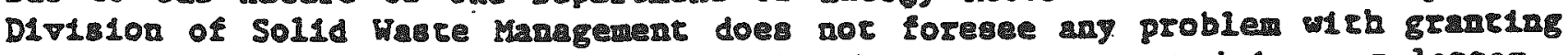
this request. You may use the schles thre have been requested in your letrer.

Pless feel free to contace eicher BII krispir of Jackle Okoreeh-Bah 15 you have any questlons regarding chlo locres.

Siacerely,

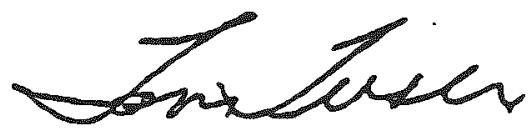

Tom Ilesler, Director

D171810n of Sol1d Waste Magement

JII/BK/F1011297

Ce: Sherry Lankford, DOE H1112am Brovn, MALS/Y-12

Gary Bodearia, DOE

H. G. MCMLLLaR, DOE

James Serrbrough, EPA

BL1L RELPPIE, TDEC/SMM

Jacke Okoreeh-Ban, IDEC/SMM

Eard Laming, IDEC 
APPENDIX B-2

WIND ROSES 
WIND ROSE for Tower W( $60 \mathrm{~m})$ for 01/01/90 - 12/31/90

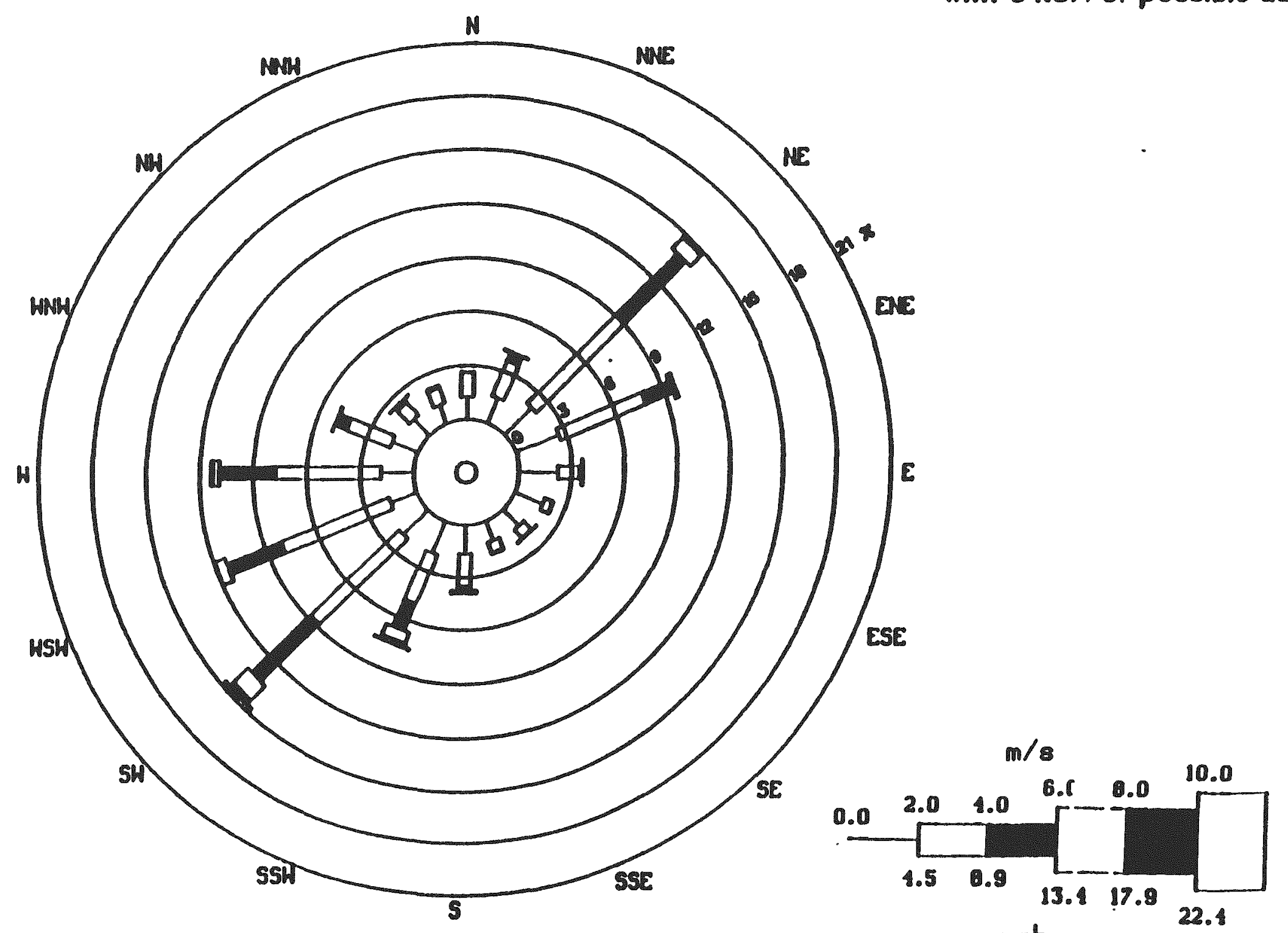

FIGURE B-1. Wind Rose from the West Meteorological Tower at 60 meters at the Y-12 Plant ${ }^{m p h}$ B-1-1 


\section{WIND ROSE for Tower $E(100 m)$ for 01/01/90 - 12/31/90}

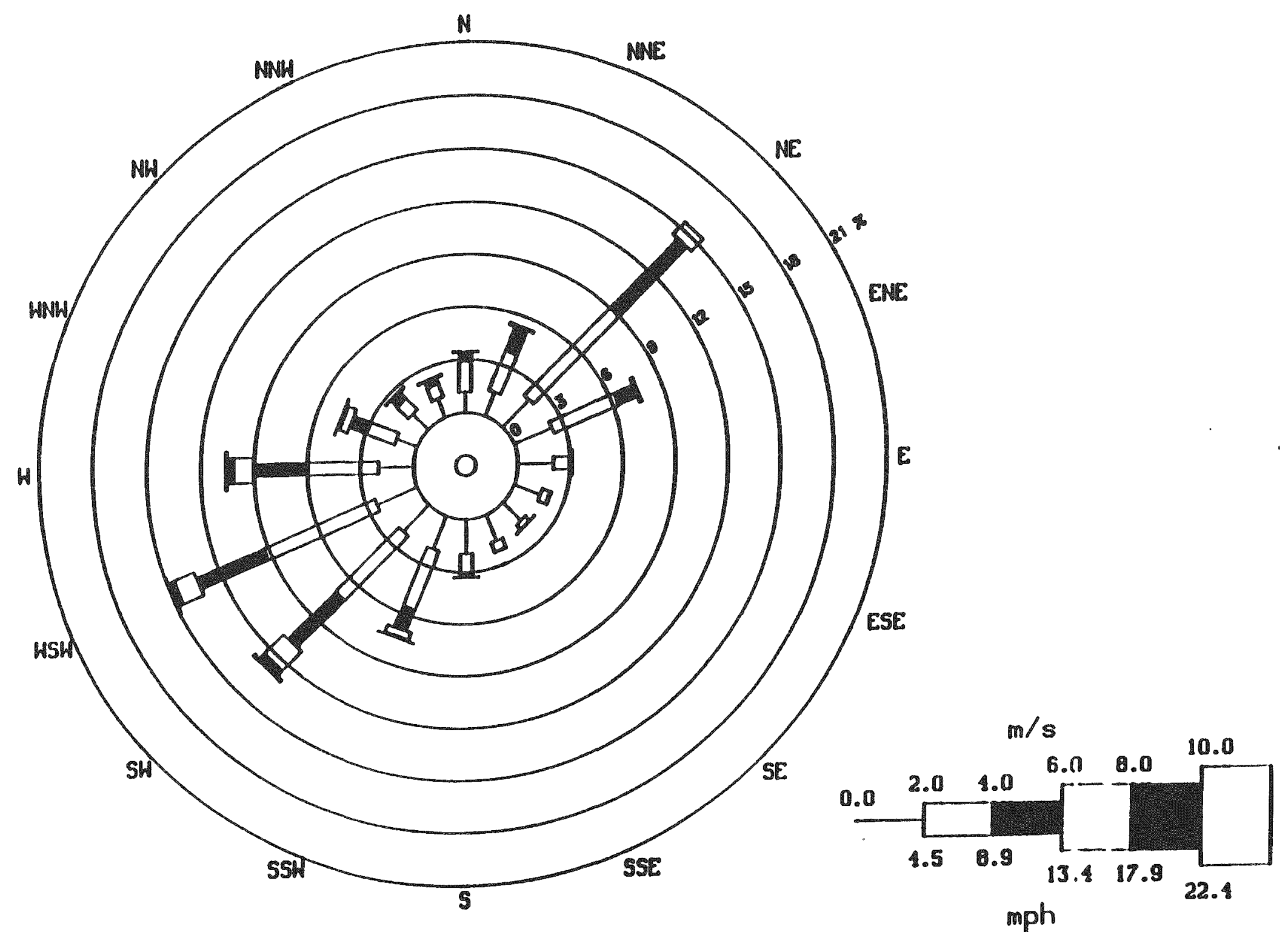

FIGURE B-2. Wind Rose from the East Meteorological Tower at 100 meters at the Y-12 Plant 


\section{APPENDLX C-1}

TYPICAL WASTE ANALYSIS DATA 
LAB RESULTS

LOC: 9201-5N DECOMPOSED CYANIDE

SAMPLE PI:

SAMPLE DATE: $10 / 29 / 1986$

$1187 / 1986$

REQ : $536 \overline{125}$

REQUESTOR: J J RUSSELI

ALI RESULTS IN MG/L UNLESS OTHERWISE NOTED

$\begin{array}{lr}\text { Ag } & 0.43 \\ \text { Al } & 35 \\ \text { As } & <0.005 \\ \text { B } & 4.3 \\ \text { Ba } & 1.6 \\ \text { Be } & <0.03 \\ \text { Ca } & 420 \\ \text { Cd } & <0.30 \\ \text { Co } & 0.19 \\ \text { Cr } & 3.2 \\ \text { Cu } & 0.26\end{array}$
太ICPA

E $\quad 170$

K

7900

Lำ

Mg

Mn

Mo

Ma

Nb

$\mathrm{Ni}$

$$
\begin{array}{r}
0.12 \\
38 \\
12 \\
60.40 \\
11000 \\
2 \quad .0 \\
7.7
\end{array}
$$

$\mathrm{Hg}$

Iotal Residual

PCE

0.003

Se

$<0.001$

Phosphates

90

Cyaride

con chemecal répheridemant 6040

suspended Solids

Dissolved Solids

Density

CI

E

C1 Hydrocarbons

Suliates

Nitrates

1000

IOC FOTH ORGAME CARBON 500

pH

8.0

Alkalinity(as Caco3)

2040

u

1.1900

12

Acidity

$235 \mathrm{U}$

* $*$ RAIIOLOGICAL PARAMEIERS *A (PER ML)

Alpha Activity

Gama Activity

$$
0.008 u C i \text { Beta Activity }
$$

$<\quad 1.0 \mathrm{pCi}$

h*ORGANICSA

Methylene chloride

Methyl chioroform

Irichloroethyelene

Perchloroethylene

Pherols $2.0 \mathrm{pCi}$

$$
\begin{aligned}
& <0.50 \\
& <\quad 0.50 \\
& <\quad 0.50 \\
& <\quad 0.50 \\
& 0.44
\end{aligned}
$$

Notes or Auditional Results

IOTAL RESIDUAL CHLORINE $6.0 \mathrm{MG/L}$ 
LAE RESULIS

LOC: 9201-5N DECOMPOSED CYANIDE SAMPLE PI:

SAMPLE IATE: $10 / 29 / 1986$

DUPLICATE ANALYSIS

O PPH

u 235

1.03 wt $\%$

11/4/1986

REQ : 536126

REQUESTOR: J J RUSSELL 
RADIOACTIUITY CALCULATION

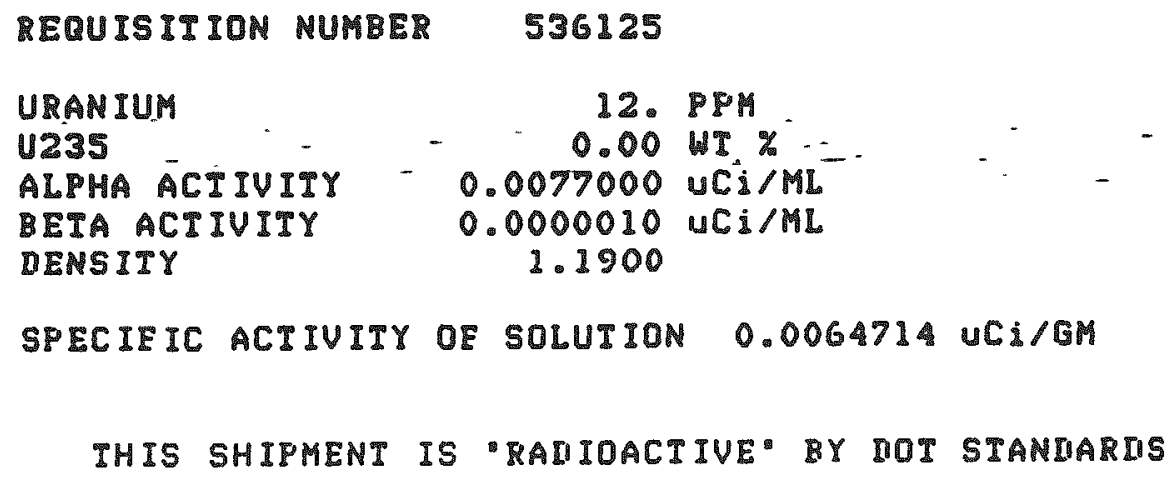


APPENDDX C-2

WASTE IOENTIFICATION FORMS 
"ASTE ITENIDENTITICATION

\section{ste item ID vumber D. Generator s varme iprust}

13. Badge No. it Generators Phone to. 115 . MS

I11. Origun RoomiArea
10. Charge Number/tho

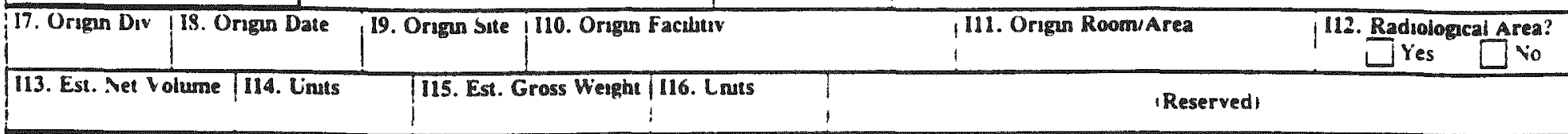

CONTAINER INFORMATION ( 1 of ) II more than one atrach Waste Container List (UCN-2109A)

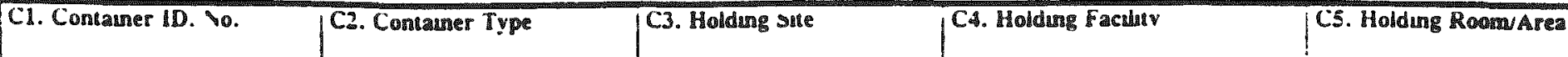

\section{WASTE CATEGORY}

Wi. Process stream ID W2. Process Category

13. Process Actuvay

Wh. Physacal Form

177, Waste Descriptuon
W6. AWA No.

\section{CIEMICAL WASTE}
MI. RCRA?
M2. RCRA Nov STan Date
M3. PCS?
$\square$ Yes
No
M4. PCB Stant Date
$\square$ Yes $\square$ No

\begin{tabular}{|c|c|c|c|c|c|}
\hline \multicolumn{6}{|c|}{ W8. W aste Category (Check all) } \\
\hline & Fes & 50 & & Yes & No \\
\hline Chenncal & 1 & & Brologica! & & \\
\hline Radroacrive & 1 & & Accountable & & \\
\hline Asbestos & 1 & & Carcunogen & & \\
\hline Sanind & 1 & & Compacuble & & \\
\hline Const Debrys & & & Recriable & & \\
\hline Medical & & & Classinted & & \\
\hline
\end{tabular}

\section{and} (Check ONE)

$\square$ Amalysis

Process Knowledge Reference

M7. Desermunatem Document Number(s)

M10. EPA Waste Code Numbers

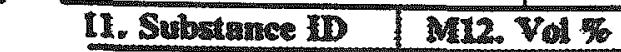 \\ RADIOACTIVE WASTE

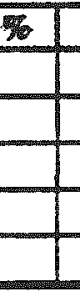

M13. Substance Nane

M5. PCB Conc. (PPM)

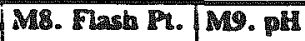

RI. RAD Category (Cbecls ONE)

$\square$ TRU $\square$ High-Level $\square_{\text {Low-Level }} \square_{\text {special }} \square$ VLA

12. RAD Mandinge Iype

R3. UCN 2681 No.

\section{R4. Determunation Metbod}

(Check ONE)

D5. Determinatica Docriment Number(s)

Pracess Knowledge $\square$ Reference R6. Chemeal Form

R7. Isotope

R\&. Est. Qty

R9. Units

77. Isolops

R. Est. Qty

199. Uhists

(Reserved)

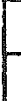

\section{HANDLING INFORMATION}

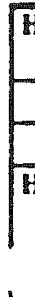

1. Mandhang Instructoons

12. Respurator

$\square$ vione $\square$ Half $\square$ Full

13. Cartindge Type

krep Sine

\begin{tabular}{|c|c|}
\hline & $\begin{array}{l}\text { MA. MP Tas } \\
\text { Color }\end{array}$ \\
\hline & Alpha \\
\hline \multirow{2}{*}{ H3. Cartridge Type } & Beta/Gamma \\
\hline & Veutron \\
\hline
\end{tabular}

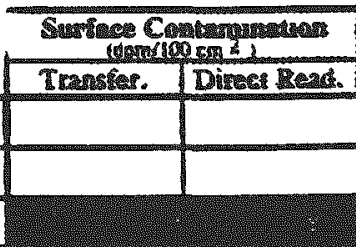

H6. Puckup Focility
R7: Isotope
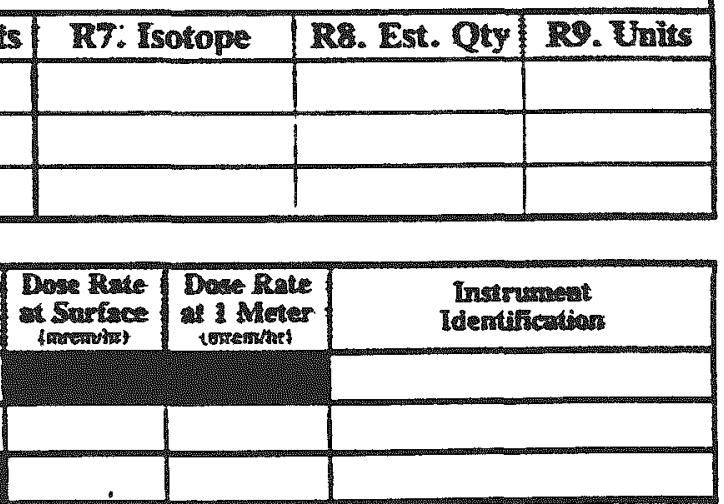

H7. Pickup Area

\section{SIGNATURES and APPROVALS}

\begin{tabular}{|c|c|c|c|c|c|}
\hline \$1. Cienerator & Badge & 1 Date & S2. MP Techuran & 1 Badge & Date \\
\hline 53. Ierfification Ufficer & Badge & $1^{\text {Date }}$ & S4. Denvauve Classufier & Badge & $\begin{array}{l}\text { Date } \\
1\end{array}$ \\
\hline
\end{tabular}


(Continuation Page of

\begin{tabular}{|c|c|c|}
\hline \begin{tabular}{c|c} 
Sequence \\
Vumber
\end{tabular} & Referenced from & WTD (UCN-2109)* \\
\cline { 2 - 3 } & II. Waste Item ID Number & C1. Contanner ID. No. \\
\hline
\end{tabular}

\section{- ALL WASTE ITEM/CONTAINERS ON THIS FORM HAVE THE SAME CHARACTERISTICS AS ITEM/CONTAINER NUMBER I}

\begin{tabular}{|c|c|c|c|c|c|c|c|c|}
\hline \multirow{4}{*}{$\begin{array}{l}\text { Sequ : } \\
\text { Numbe: }\end{array}$} & \multicolumn{2}{|c|}{ II. Waste Item ID Number } & Cl. Contaner ID. No. & \multicolumn{2}{|c|}{ 18. Orgne Date } & \multicolumn{2}{|c|}{ 12. RCRA 90-day Stan Date } & \multirow{3}{*}{$\frac{\text { M14. PCB Start Date }}{\text { Instrumest }}$} \\
\hline & \multirow[t]{2}{*}{ 113. Est. Net Volume } & \multirow[t]{2}{*}{ 114. Uants } & \multirow{2}{*}{$\begin{array}{l}\text { H4. HP Tag } \\
\text { Color }\end{array}$} & \multicolumn{2}{|c|}{ Surface Cortangurans } & \multirow{2}{*}{$\begin{array}{c}\text { Dose Rase } \\
\text { Sartace } \\
\text { (motemisis) }\end{array}$} & \multirow{2}{*}{ 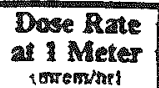 } & \\
\hline & & & & Transter. & Direci Stead. & & & \\
\hline & I15. Est. Gross Weight & 116. Lines & Alpha & & & & & \\
\hline \multirow{2}{*}{\multicolumn{3}{|c|}{ Commenrs }} & Beca/Gamma & & & & & \\
\hline & & & Neurzon & & & & & \\
\hline
\end{tabular}

\begin{tabular}{|c|c|c|c|c|c|c|c|c|}
\hline \multirow{4}{*}{$\begin{array}{l}\text { Sequence } \\
\text { Number }\end{array}$} & \multicolumn{2}{|c|}{ 11. Waste Itera ID Number } & C1. Contaner ID. No. & \multicolumn{2}{|c|}{ 18. Origun Date } & \multicolumn{2}{|c|}{ 12. RCRA 90-day Siar Date } & \multirow{3}{*}{ 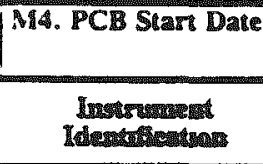 } \\
\hline & \multirow[t]{2}{*}{ 113. Est. Net Volurae } & \multirow[t]{2}{*}{ 114. Unus } & \multirow{2}{*}{$\begin{array}{l}\text { 14. MIP Tag } \\
\text { Color }\end{array}$} & \multicolumn{2}{|c|}{ 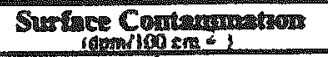 } & \multirow{2}{*}{$\begin{array}{l}\text { Dose Rate } \\
\text { Surface } \\
\text { Stmennet? }\end{array}$} & \multirow{2}{*}{ 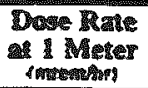 } & \\
\hline & & & & Transter. & Dinest Read. & & & \\
\hline & 115. Est. Gross Werght & 116. Unus & Alpha & & & & & \\
\hline \multirow[t]{2}{*}{ Comanerats } & & & Beta/Gamma & & & & & \\
\hline & & & Neurron & & & & & \\
\hline
\end{tabular}

\begin{tabular}{|c|c|c|c|c|c|c|c|c|}
\hline \multirow{4}{*}{$\begin{array}{l}\text { Sequemee } \\
\text { Numaber }\end{array}$} & 1. Waste Item 10 Namber & Cl. & C1. Contanat ID. No. & \multicolumn{2}{|c|}{ 18. Origan Date } & \multicolumn{2}{|c|}{ M2. RCRA 90-day Start Dat } & \multirow{3}{*}{$\frac{\text { M4. PCB Start Date }}{\text { : }}$} \\
\hline & \multirow[t]{2}{*}{ 13. Est. Net Volume } & \multirow[t]{2}{*}{ 114. Urahs } & \multirow{2}{*}{$\begin{array}{l}\text { MA. HP Tag } \\
\text { Color }\end{array}$} & \multicolumn{2}{|c|}{ 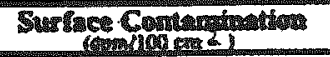 } & \multirow{2}{*}{ 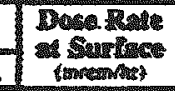 } & \multirow{2}{*}{ 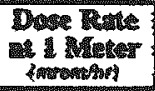 } & \\
\hline & & & & Transfer. & Direa Read. & & & \\
\hline & 15. Est. Gross Weaght & 116. Units & Alpha & & & & & \\
\hline \multirow[t]{2}{*}{ Cormments } & & & Beta/Gamma & & & & & \\
\hline & & & Neutron & & & & & \\
\hline
\end{tabular}

\begin{tabular}{|c|c|c|c|c|c|c|c|c|}
\hline \multirow{4}{*}{$\begin{array}{l}\text { Sequance } \\
\text { Neronber }\end{array}$} & 11. Waste Item ID Nuraber & CI. & Cl. Contaner ID. No. & \multicolumn{2}{|c|}{ 18. Origio Date } & \multicolumn{2}{|c|}{ M2. RCRA 90-day Stant Date } & \multirow{3}{*}{ 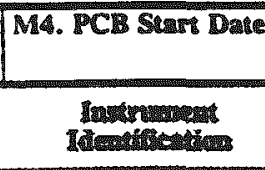 } \\
\hline & \multirow[t]{2}{*}{ 113. Est. Net Volune } & \multirow[t]{2}{*}{ 114. Unaits } & \multirow{2}{*}{$\begin{array}{l}\text { MU. IL Tas } \\
\text { Coler }\end{array}$} & Starlese & 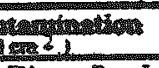 & \multirow{2}{*}{ 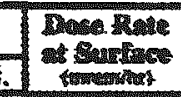 } & \multirow{2}{*}{ 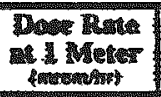 } & \\
\hline & & & & Trunster: & Dires head. & & & \\
\hline & 115. Est. Gross Weight & 116. Unus & Alpha & & & & & \\
\hline \multicolumn{3}{|l|}{ Comaneats } & Beta/Gamm & & & & & \\
\hline & & & Neutron & & & & & \\
\hline
\end{tabular}

\begin{tabular}{|c|c|c|c|c|c|c|c|c|}
\hline \multirow{4}{*}{$\begin{array}{l}\text { Sequence } \\
\text { Number }\end{array}$} & \multicolumn{2}{|c|}{ I1. Vaste ltern ID Nuraber } & C1. Contaner 10. No. & \multicolumn{2}{|c|}{ 18. Orngax Date } & \multicolumn{2}{|c|}{ 12. RCRA 90-day Stan Date } & \multirow{3}{*}{ 14. PCB Start Dar } \\
\hline & \multirow[t]{2}{*}{ 113. E5t. Net Volume } & \multirow[t]{2}{*}{ 114. Units } & \multirow{2}{*}{$\begin{array}{l}\text { M4. MP TE } \\
\text { Color }\end{array}$} & \multicolumn{2}{|c|}{ 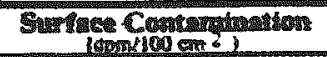 } & \multirow{2}{*}{ 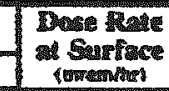 } & \multirow{2}{*}{ 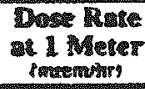 } & \\
\hline & & & & Tremser & Direch Read & & & \\
\hline & 115. Est. Gross Wenght & 116. Unats & Alpha & & & & & \\
\hline \multirow[t]{2}{*}{ Cormments } & & & Bera/Gamma & & & & & \\
\hline & & & Neutron & & & & & \\
\hline
\end{tabular}

SIGNATURES and APPROVALS

\begin{tabular}{|l|l|l|}
\hline S1. Generator & Badge & Date \\
\hline S3. Veríication Oficer & Badge & Date \\
\hline
\end{tabular}

\begin{tabular}{|l|l|l|}
\hline S2. HP Techncian & Badge & Date \\
\hline S4. Derivanve Classifier & Badge & Date \\
\hline
\end{tabular}




\section{WASTE MANACEMEN SECTION}

DOT Rad $>=2000$

$$
\frac{\square \text { Yes } \square \text { No }}{\text { and Class/Dnision }}
$$

\begin{tabular}{|c|c|c|}
\hline Regured Labeis/Markags/Tass Correct & Do \\
\hline Yes $\square$ No & \\
\hline
\end{tabular}

9 Moatu/ Year FCP Dase

\section{DOT Shppuss Name}

Sample Reg̨uest Nurgaber

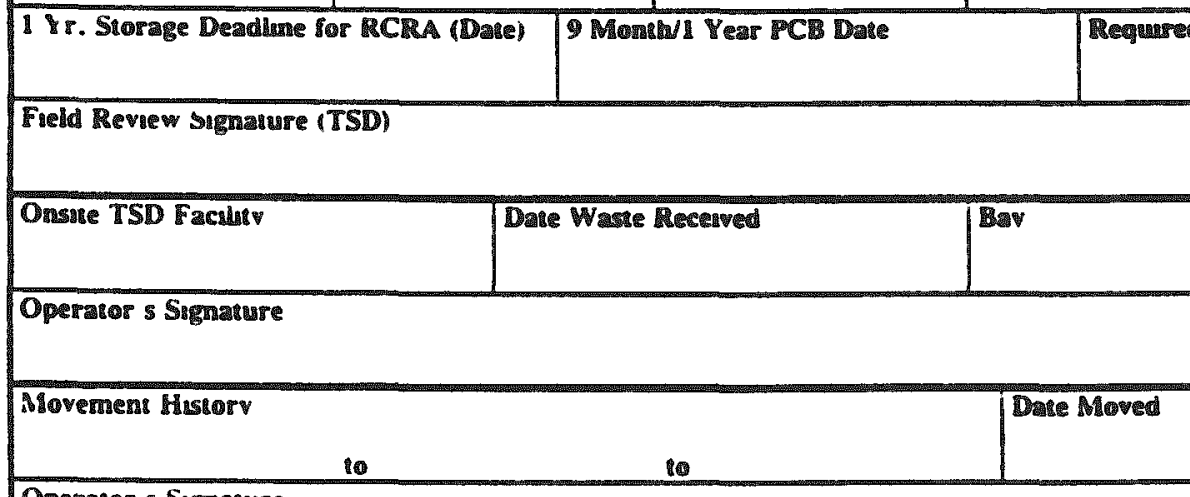

Operator s Sigmature

10

10

:

\section{Disposal Mielhod/Code}

Drsposal Pachlaty/Company

Madme Numbers

Date Sampled

Samplans Code Nurreber

Waste Manfiest Number

CD Recenp Date

Shappung Coordinater S Signature

Badge Number

Date

Dusposal Instructions 


\section{ENERGY SYSTEMS WASTE DISPOSAL REQLEST}

\section{CNi-2109 Pronile Sheer}

\section{WASTE MTEM IDETTICATTO:}

14 aste isem 10 : Vumber. The unoue $1 D$ numeer or trie waste item

$\therefore$ Ginerator s ivame. The name of the inuw suas responsibue for ine generation of the waste

13 Badge tyo The bauge number or the waste generator.

is lenerator s Phone No Phone number unere tne waste generator can de reacned

is biall siov

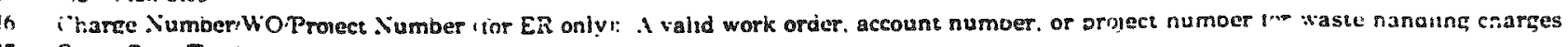

1- Origin Div The division code or the originaning division

18 Origin Date The date that the waste was generated

(4) Origin bite The site (plant) where the waste was generated

110 Origin Facilur The tacuisy (buidingl where une waste was ge. ased

i1! Origin Room Area The room or area where the waste was g: sted

112 Radiological Area. The generation area is a radiological area ives of no

113. Est. Niet Volume. The estumated net volume of the waste material

114 Unus volume unus

IIS Est Gross Weight: The estumated gross weight of the waste matertal

116 L aus: Weight unus

\section{CONTANER INPORMATION}

C1. Cuntaner ID No. The unque ID number or the stuopmgistorage conmane for this waste tem

C2 Conauner Type: The rype code for the shipping'storage contaner

C3 Holding Site: The site iptant where the waste was heid durtng accumuiation

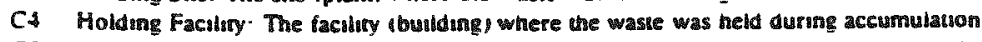

C5. Hold ing Room Area: The poom number of area udenurier where une waste was held durng accumulation

\section{WASTE CATEGORY}

W Process stream 10. The 10 number of the process stream which generateu the waste

W2. Process Culegory: The category of the process whicn generated this waste

W3. Process Actury- The descrouve mame ot the gentranon process

W4. Physacal form: The physical form of the waste maternal

WS Materal Tvpe: The sub-category of the physacal form of the mase materat

W6. A W.A Vumber: Asbertos Wort Authormation Number

W 7 Waste Descrotion. Further specufication of the waste. including descripuve intomatuon

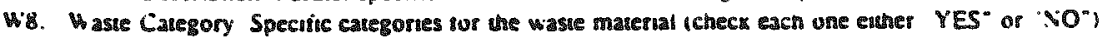

\section{CHEMECAL WASTE}

M1. RCRA (Y/N)?: The waste conams RCRA reguiated matersal

M2. RCRA 90-Day Sun Date: The date RCRA waste was placed in a 90-day storage areal

M3. PCB IYNN)?: The wasse conkun PCD regutated matergal

M4. PCB Stagt Date: The dast PCB waste matersal was removed from service

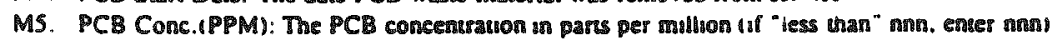

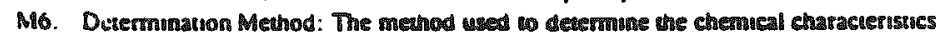

17 Ditemunation Document Number(s): Document numbers ghat substantuate the detemunanon of he chanacterisucs

ifs Flash Prom. The flash point of the asse materal tolegress C)

190 Pit The reianve actidiy of the waste materul (phi)

410 EPA Waste Code Numbers: The EPA aste code numbers derenmuned from ane waste characterisucs

MII Substance ID The ID number of a chernical consumen of the wasse terther ats CAS number or MSDS record number

112. Vol : The percent oy volume for the cherncal subsance

M13. Substance Name: The common mane of the chemucal substance

\section{RADIOACTITE WASTE}

R1. Rat Category. The radioacure waste category code chect one

R2. Rad Handing Type: The gadioachve waste nanding code

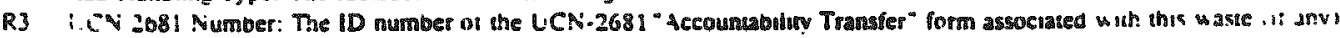

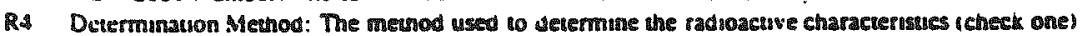

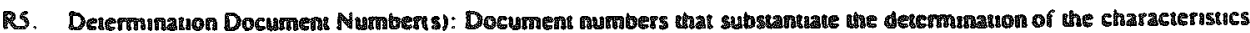

R6 Chernical Fom. The chernical form of the waste matersal

Ry Isotoos 10 The 10 number of a parucutar palioachye tsotope contand in this waste stem

$\therefore 8$ F.s. Ouanuty The esumated ouantuty of this usotope

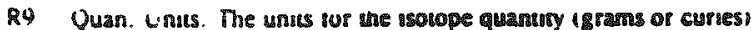

\section{HANDLERG INFORALTION}

HI thanding Instructons: Generai hand ims instructuons for the waste

H2 Rssirator Respurator gequirements to handung this waste

H3. Currrige Type. Resprrator cartrdge type to be used uf appucabie

H4 HP Survey Dara (compleled by Heatht Ptysues lectmesan)

HP Taz Color The color code of the survev ug (G.Y.R.B)

Surtace Contammanon: The transterrable and Direct Reading couns rates $(d p \mathrm{~m} / 100 \mathrm{~cm} 2)$

Dose Rate at Surtace: The tose rate measured at the suriace imremhr)

Dose Rate at 1 Meter: The dose rate measured as I meter (mremshr)

Instrumen ID. The heath physucs insumen ID number I M" number Example: M123456

H5 Pickup Site: The sute iplant) where the waste is to be picked up

H6 Pickup Faciuty. The tacility (buiding) where the waste is to be packed up

117 Pickup Room/Area: The room number or area identafter where che waste is to be picked up

\section{SIGNATRES AND APPROVALS}

S1 Generator. The signature ot the waste generator. certufving that the unformaton on the form ts complete and accurate

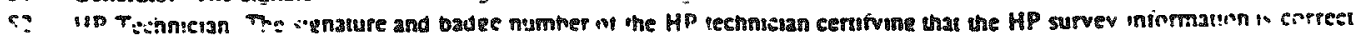

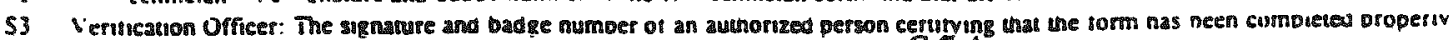

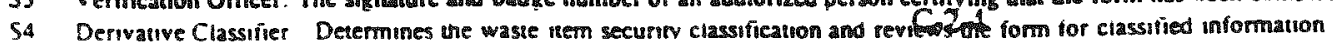


Waste Stream ID

Date Request Initiated

Pick-Up Facility ID

Contact Name

Material Form (Circle one) SOLID GAS

Waste Stream Description
WTP Request No.

Date Request Rec.

Generator Division/Plant Phone No. Badge No. SLUDGE LIQUID AEROSOL OIL

Contaminants (Circle one) ASBESTOS/BERYLLIUM/CARCINOGEN/MERCURY/PCB/OTHER Radioactive [] Yes [] No If Yes, [] Depleted [] Enriched

RCRA [] Yes [DNo (If Yes List Codes)

Respirator Required [] Yes [] No If Yes. [] Mask [] Cartridge

H.P. Tag Color Total No. of Containers

Charge No.

\section{FIELD REVIEW}

Environmental TC

Date of Field Review

Hazards

Badge No.

Date Assigned

Request rejected [] Yes [] No

Hazard Class

If Yes. Reason and Date

DOT Name

\section{SAMPLING HISTORY}

WTP PSM \#

LIMS No.

LIMS NO.

LIMS No.

Code No.

Code No.

Code No.

Code No.

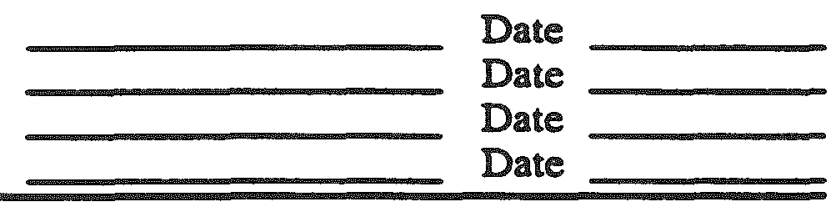

\section{MOVEMENT HISTORY}

WTP Movement No.

Delivery Site

Transporter's Signature

Transporter's Signature

Environmental TC Signoff

Delivery Date

Badge No.

Badge No.

Location

Movement No.

Delivery Site

Transporter's Signature

Transporter's Signature

Environmental TC Signoff
Delivery Date

Badge No.

Badge No.

Location

\section{DISPOSAL INFORMATION}

WTP Movement No.

Disposal Facility

Facility Operator (Signature and Badge No.

Driver's Signature

Driver's Signature

Tank No.

Date

Badge No.

Date

Badge No.

Date 


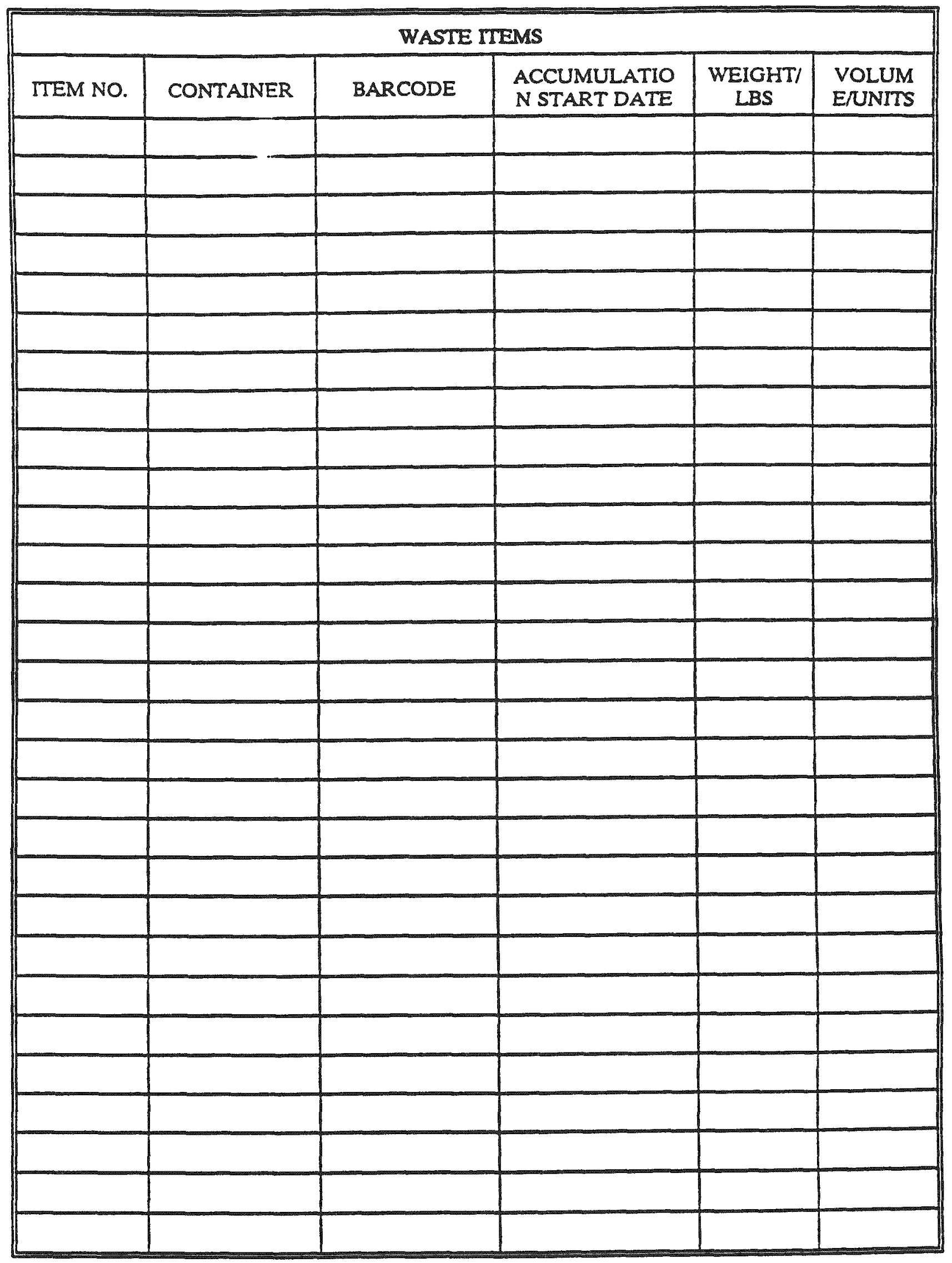




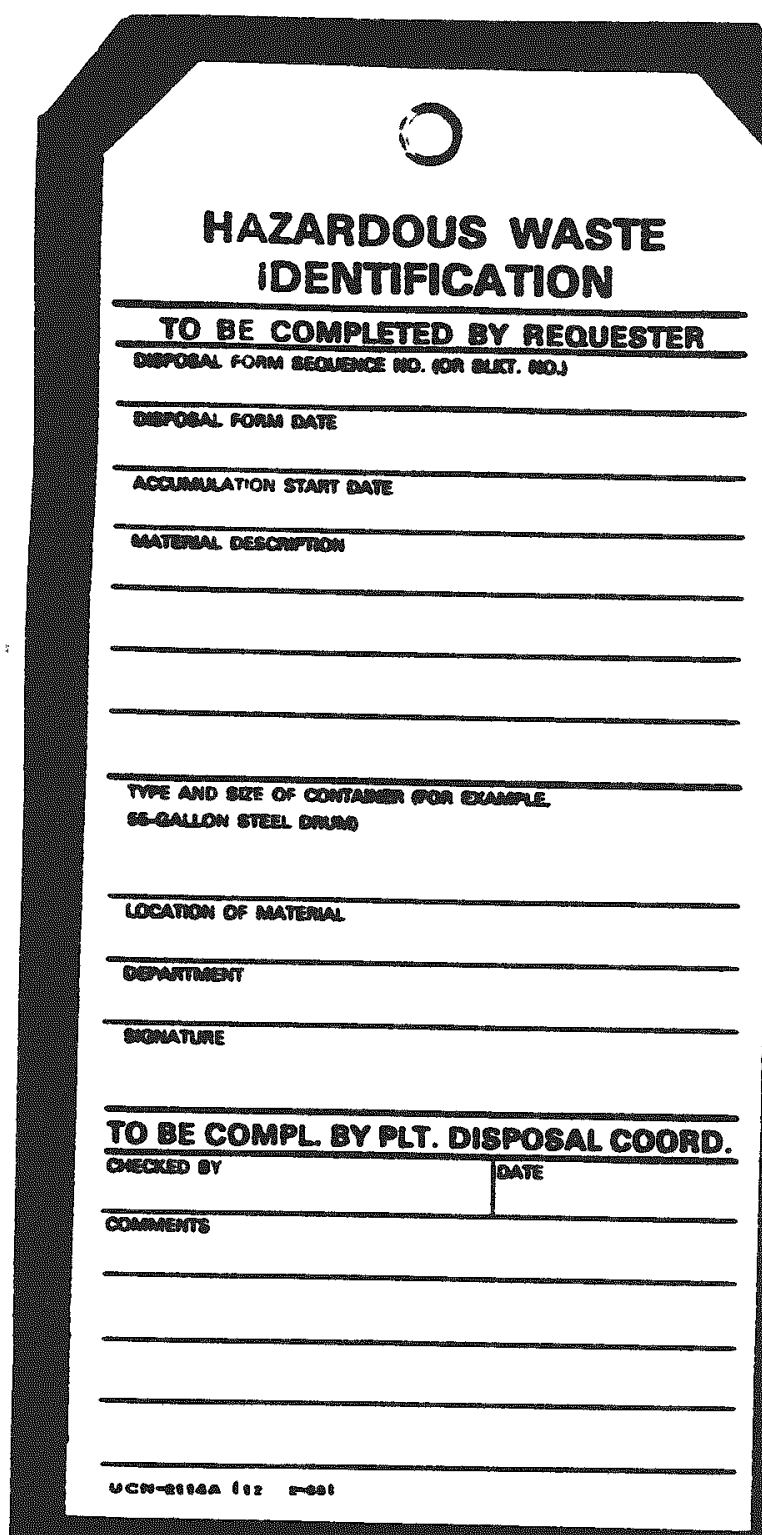

\section{0 \\ WASTE IDENTIFICATION}

TO BE COMPLETED BY REQUESTER

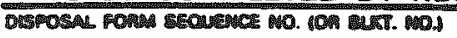

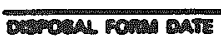

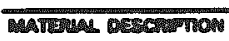

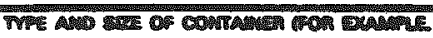

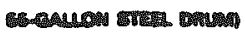

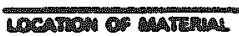

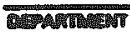

aresere

TO RE COMPL. BY PLT. DISPOSAL COOAD. cutcrer Dare 


\section{SAMPLE REQUISITION REQUEST}

REQUEST OR CONTACT

REQUESTOR'S I.D. NO. REQUESTOR'S PHONE NO.

MATERIAL DESCRIPTION

PICK-UP BUILDING PICK-UP DOCK

CONTAINER TYPE NO. OF CONTAINERS

SAMPLE REQUISITION NO. (LIMS)

SAMPLE CODE(S) SAMPLE DATE QC SAMPLE CODE RESPIRATOR REQUIREMENTS

DATE RESULTS REQUIRED BY SAMPLING PLAN 


\section{APPENDIX C-3 \\ EXAMPLES OF POTENTIALLY INCOMPATIBLE WASTE}

Many hazardous wastes, when mixed with other waste or materials at a hazardous waste facility, can produce effects which are harmful to human health and the environment, such as (1) heat or pressure, (2) fire or explosion. (3) violent reaction, (4) toxic dusts, mists, fumes. or gases. or (5) flammable furnes or gases.

Below are examples of potentially incompatible wastes, waste components, and materials, along with the harmful consequences which result from mixing materials in one group with materials in another group. The list is intended as a guide to operators of storage facilities and to indicate the need for special precautions when handling and storing potentially incompatible waste materials. This list is not intended to be exhaustive.

In the list below, the mixing of a Group A material with a Group B material my have the potential consequences as noted.

Group 1-A

Acetylene sludge

Alkaline caustic liquids

Alkaline cleaner

Alkaline corrosive liquids

Alkaline corrosive battery fluid

Caustic wastewater

Lime sludge and other corrosive alkalines

Lime wastewater

Lime and water

Spent caustic
Group 1-B

Acid sludge

Acid and water

Battery acid

Chemical cleaners

Electrolyte, acid

Etching acid liquid or solvent

Pickling liquor and other corrosive acids

Spent acid

Spent mixed acid

Spent sulfuric acid

Potential consequences: Heat generation; violent reaction. 


\section{APPENDIX C-3 (Continued) EXAMPLES OF POTENTIALLY INCOMPATIBLE WASTE}

Group 2-A

Aluminum

Beryllium

Calcium

Lithium

Magnesium

Potassium

Sodium

Zinc powder

Other reactive metals and metal hydrides

Potential consequences: Fire, explosion, or heat generation; generation of flammable or toxic gases.

Group 3-A

Alcohols

Water
Group 2-B

Groups 1-A or 1-B waste
Group 3-B

Concentrated waste

Groups 1-A or 1-B

Calcium

Lithium

Metal hydrides

Potassium

$\mathrm{SO}_{2} \mathrm{Cl}_{2}, \mathrm{SOCl}_{2}, \mathrm{PCl}_{3} \mathrm{SiCl}_{3}$

Other water-reactive waste

Potential consequences: Fire, explosion, or heat generation; generation of flammable or toxic gases. 
APPENDIX C-3 (Continued)

EXAMPLES OF POTENTIALLY INCOMPATIBLE WASTE

Group 4-A

Alcohols

Aldehydes

Halogenated hydrocarbons

Nitrated hydrocarbons

Unsaturated hydrocarbons

Other reactive organic compounds and solvents
Group 4-B

Concentrated waste

Groups 1-A or 1-B

Group 2-A wastes

Potential consequences: Fire, explosion, or violent reaction.

Group 5-A

Spent cyanide and sulfide solutions
Group 5-B

Group 1-B wastes

Potential consequences: Generation of toxic hydrogen cyanide or hydrogen sulfide gas.

Group 6-A

Chlorates

Chlorine

Chlorites

Chromic acid

Hypochlorides

Nitrates

Nitric acid, fuming

Perchlorates

Permanganates

Peroxides

Other strong oxidizers
Group 6-B

Acetic acid and other organic acids Concentrated mineral acids

Group 2-A wastes

Group 4-A wastes

Other flammable and combustible wastes

Potential consequences: Fire, explosion or violent reaction. 


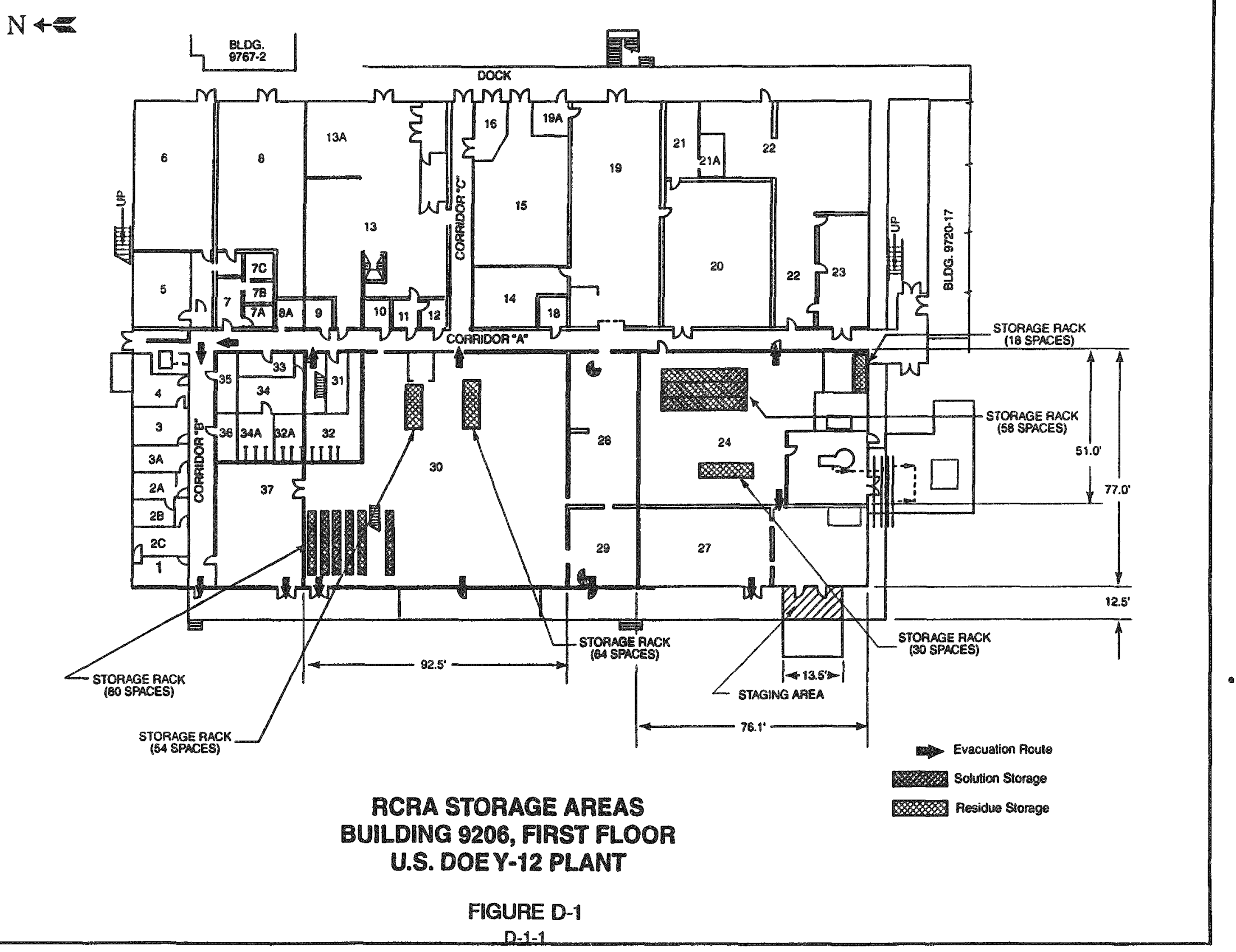




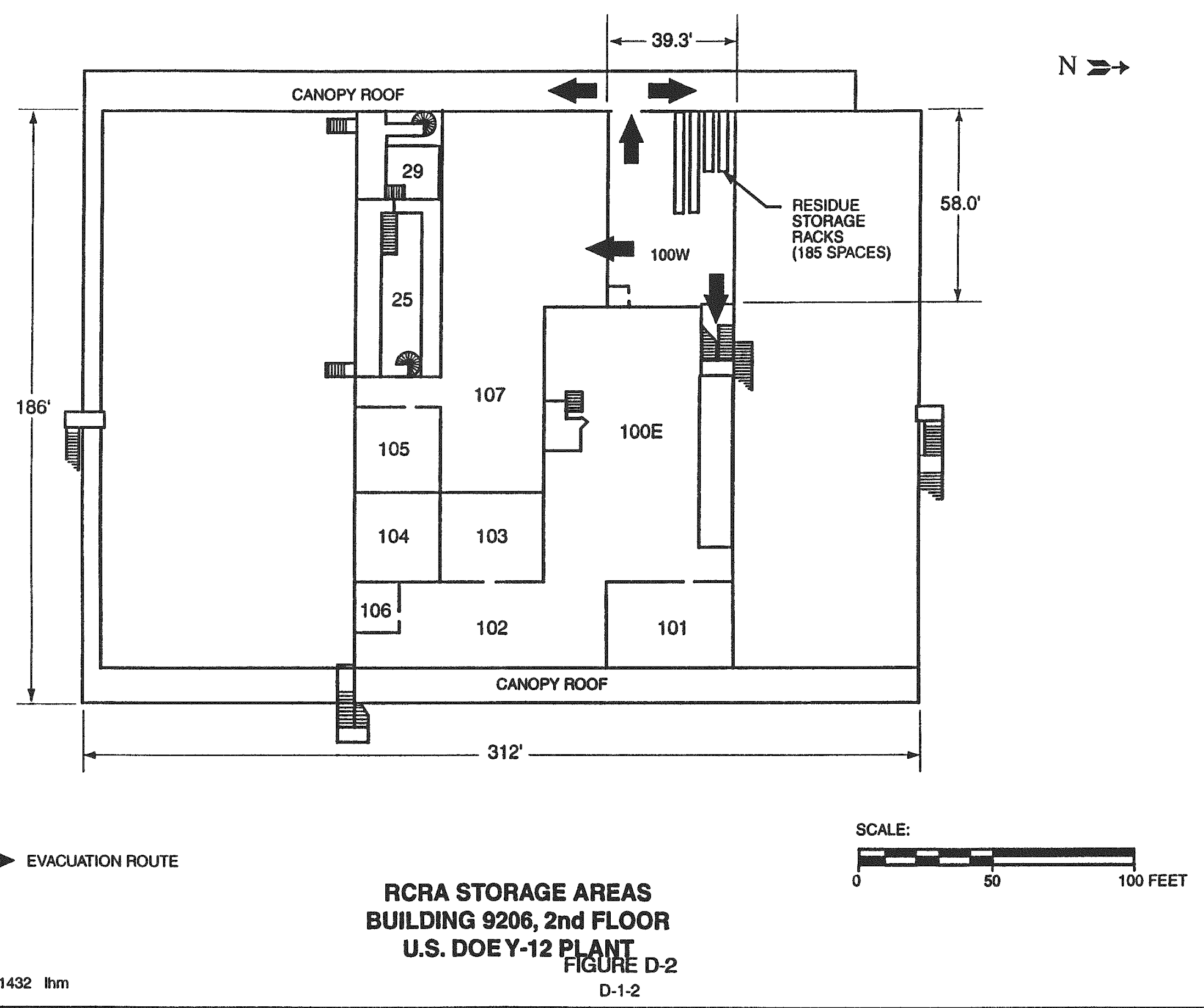




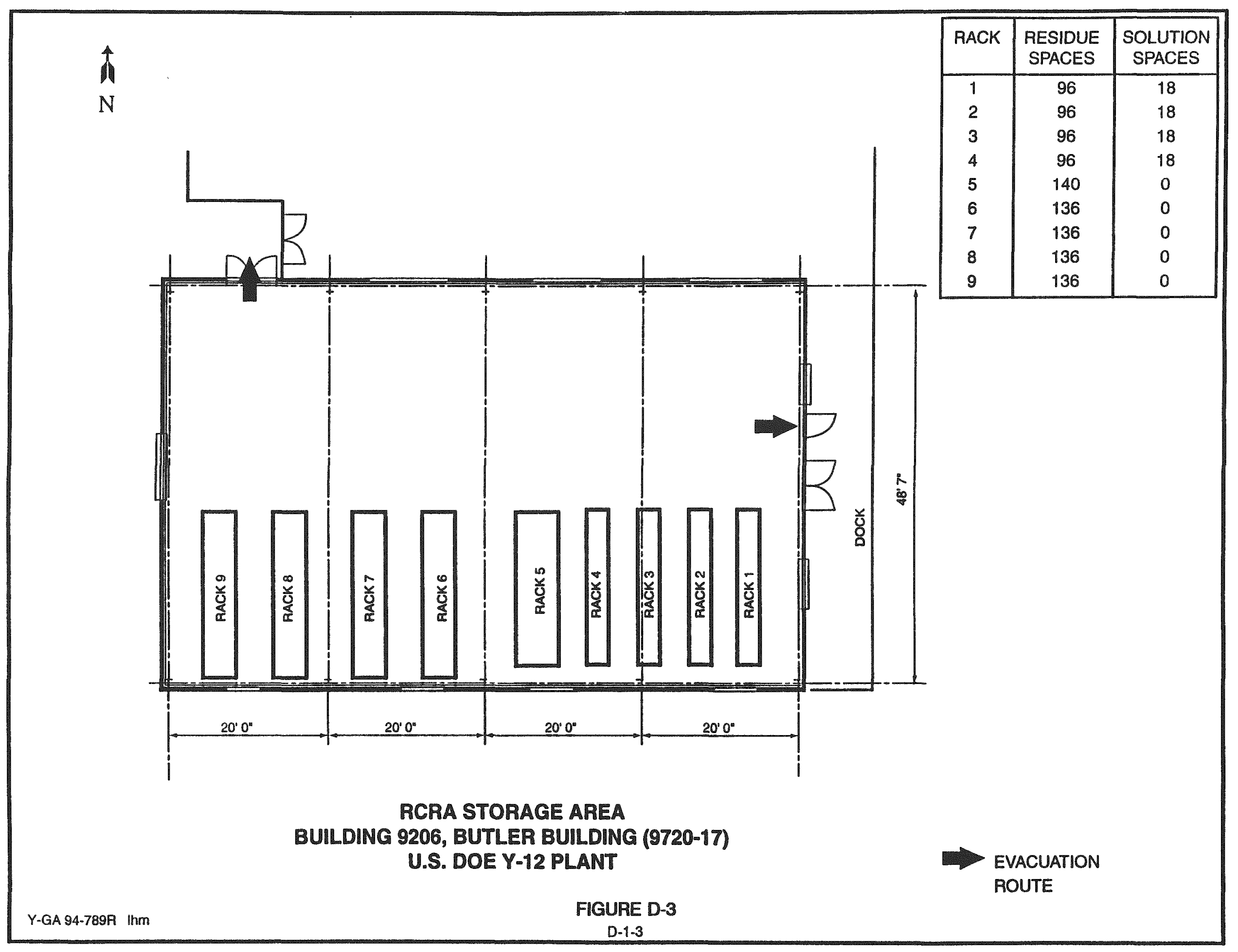




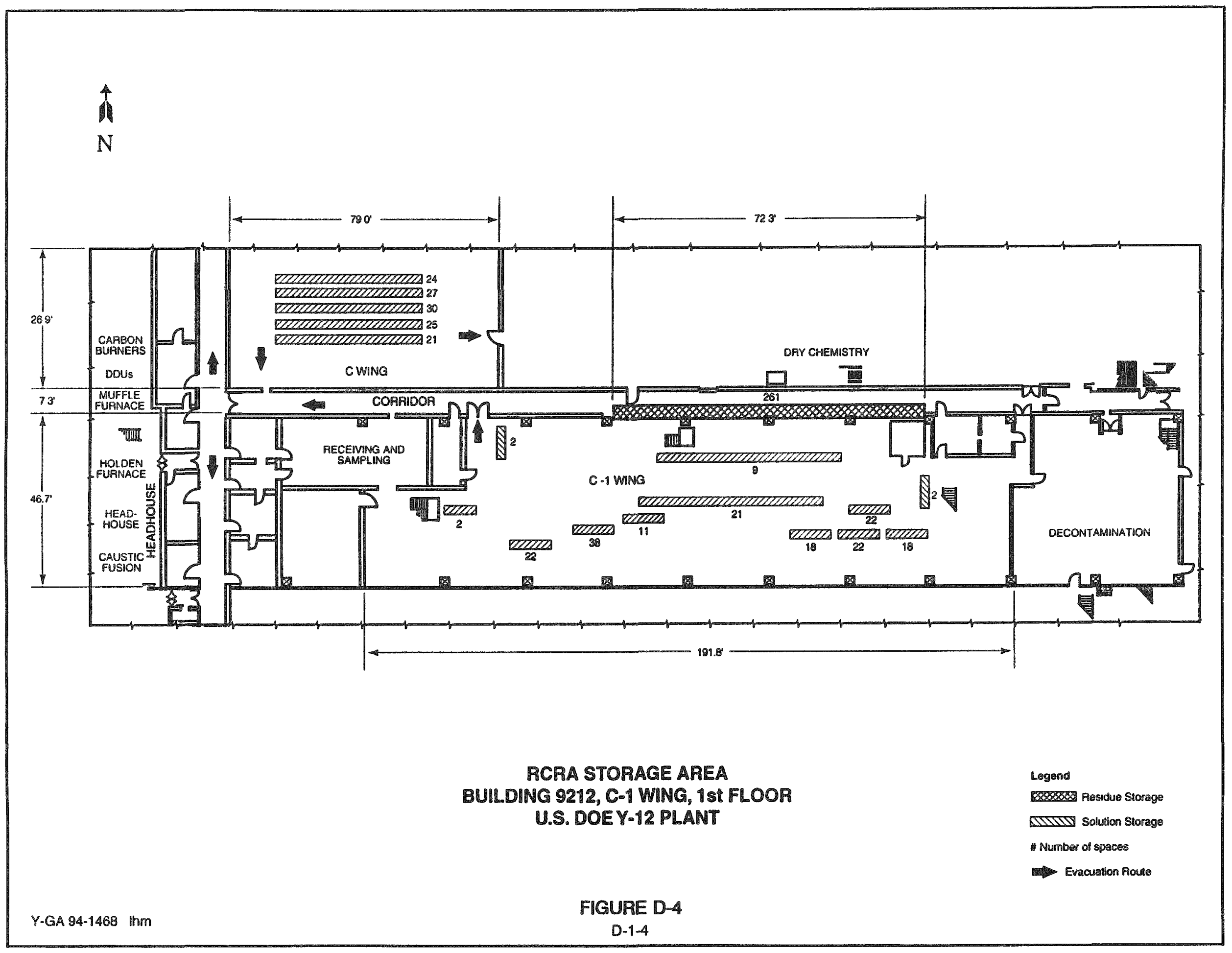




\section{† \\ $\mathrm{N}$}

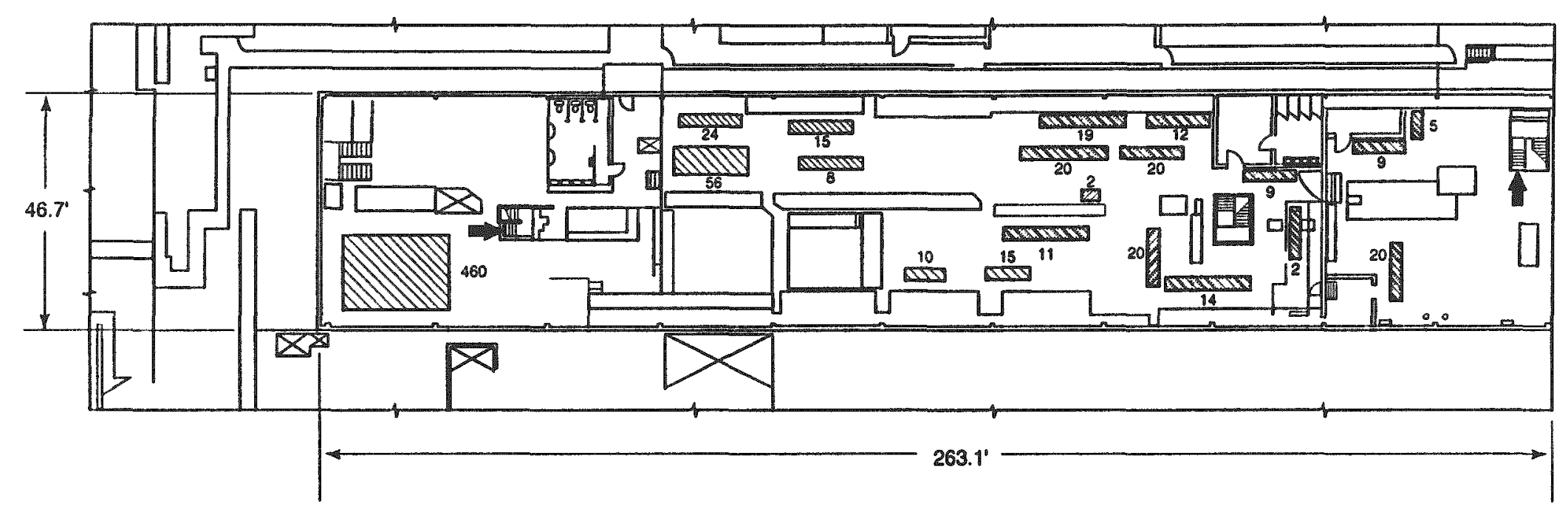

RCRA STORAGE AREAS BUILDING 9212, C-1 WING MEZZANINE U. S. DOE Y-12 PLANT
Legend

$1500 \mathrm{~T}$ Residue
Slorage Packs * No. of spaces Solution Storage Racks - Evacuation Routo 


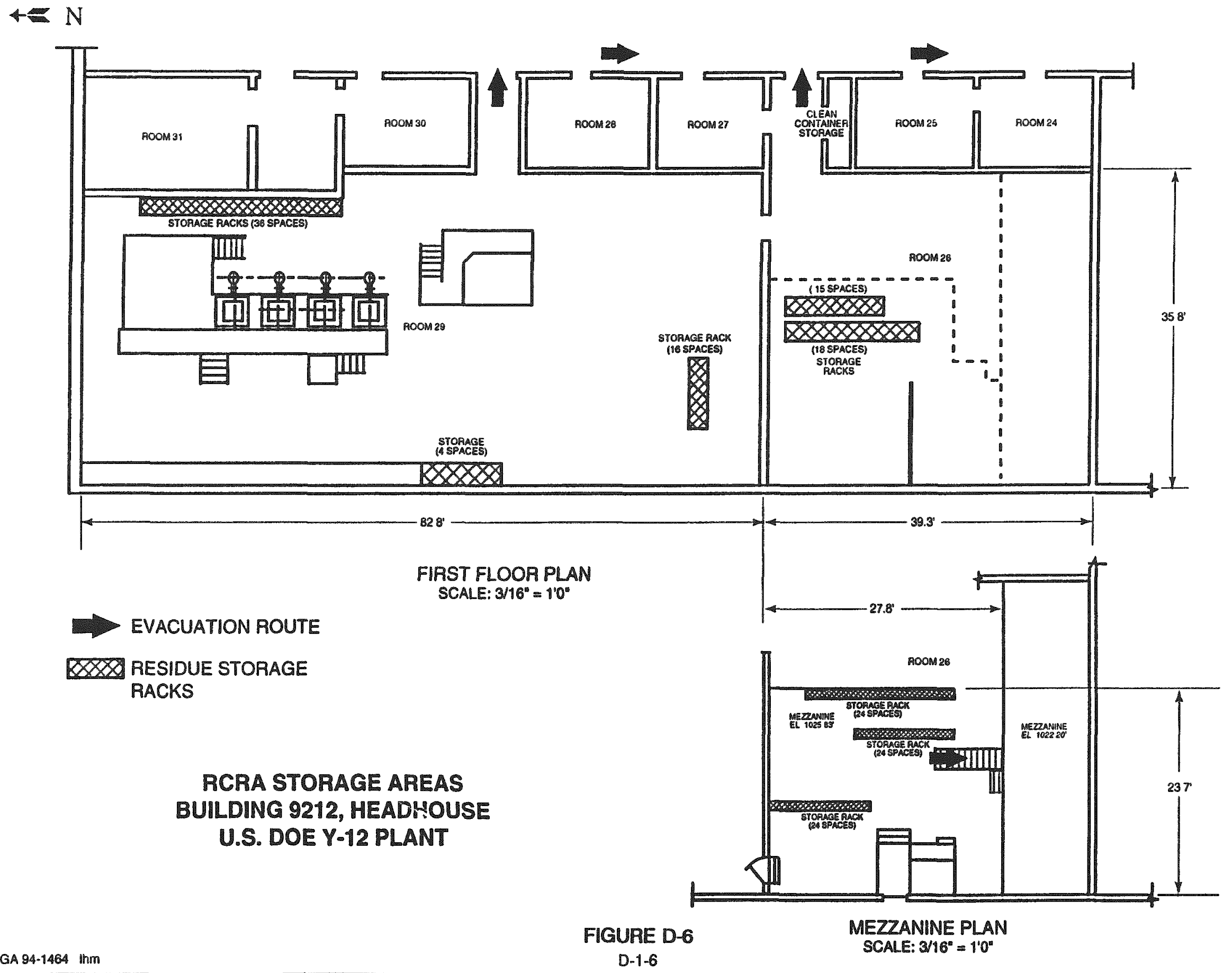


$4=N$

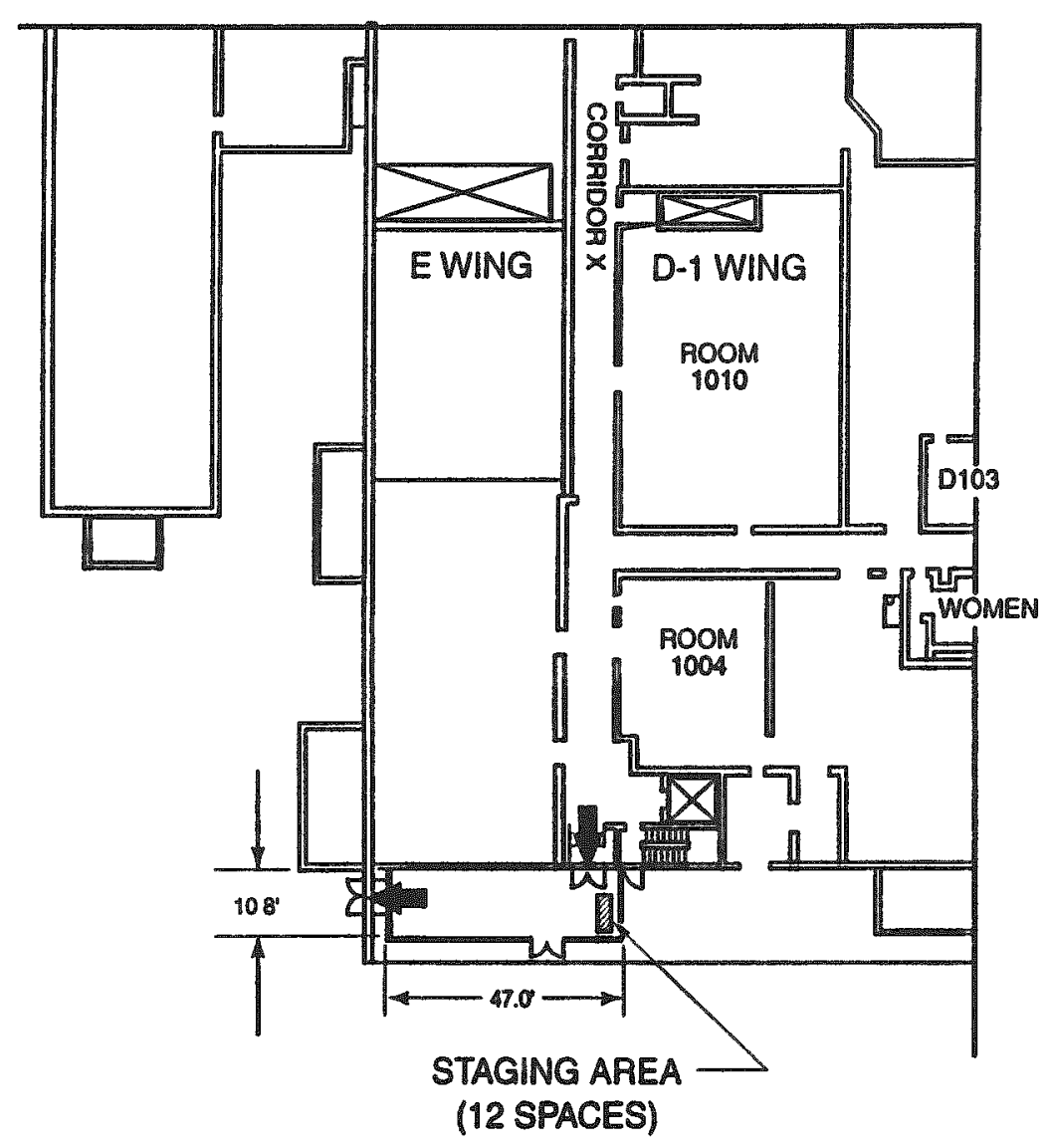

RCRA STORAGE AREA

BUILDING 9212

\section{U.S. DOE Y-12 PLANT}

FIGURE D-7

$D-1-7$ 


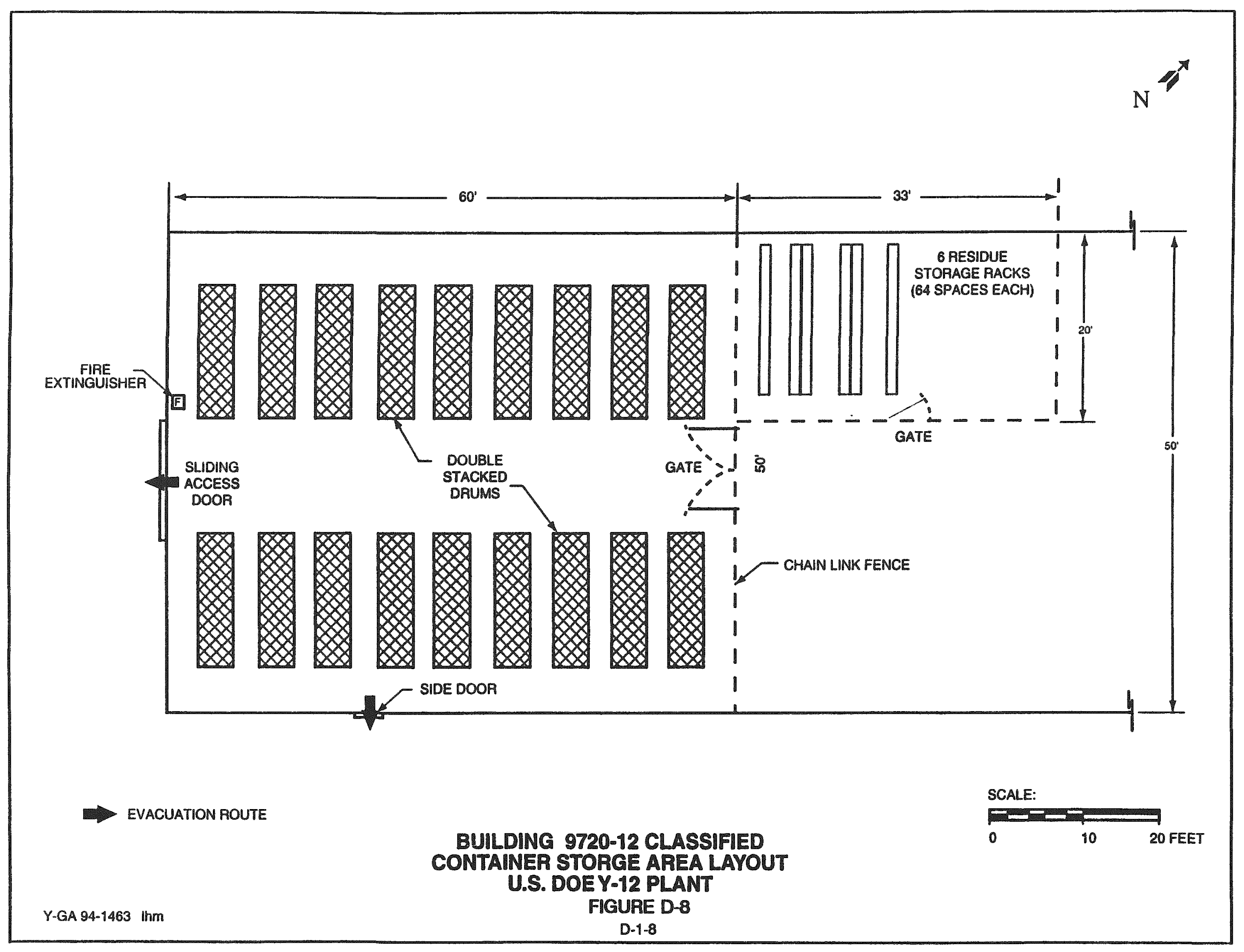




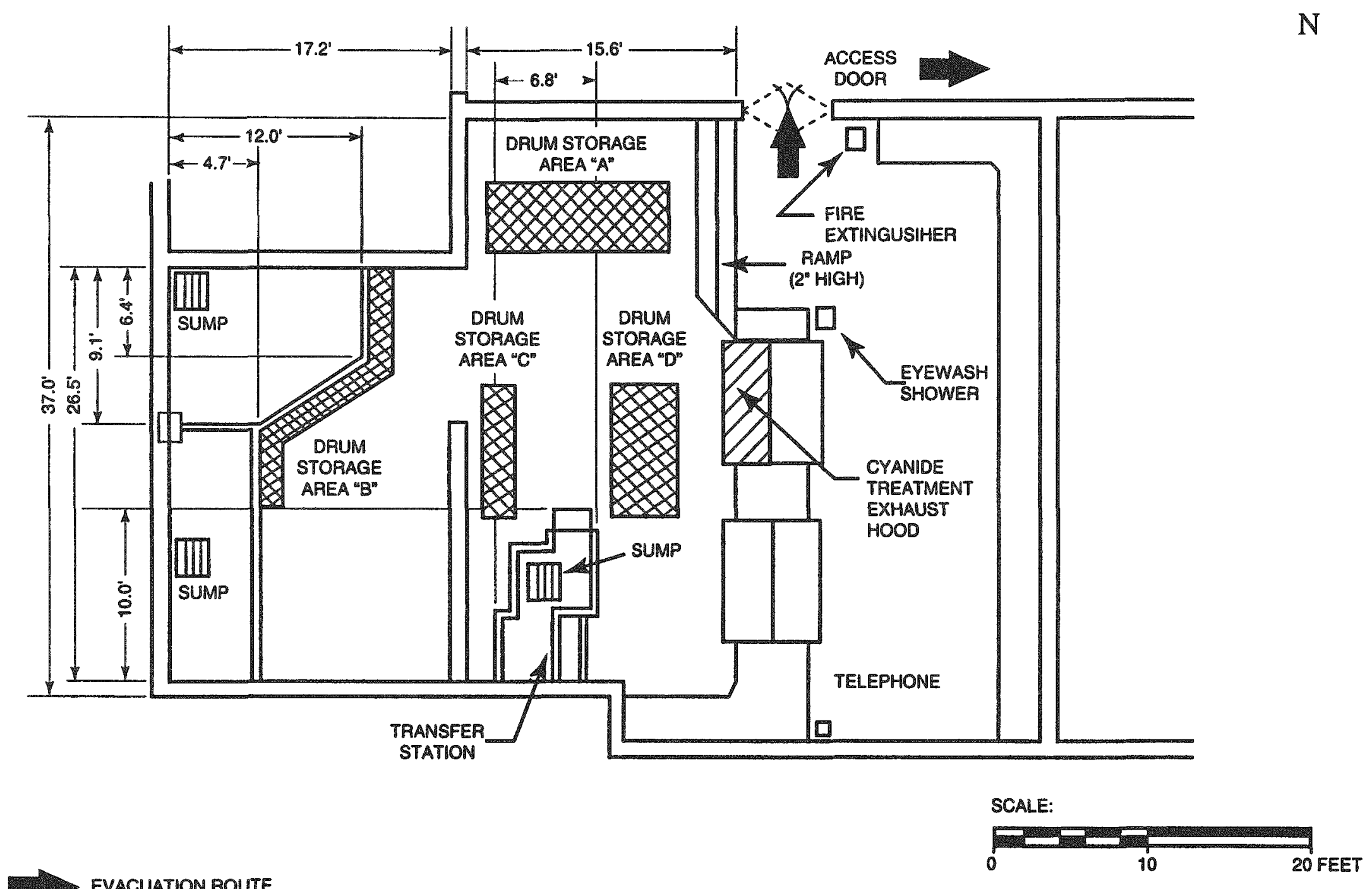

\section{CYANIDE TREATMENT UNIT BUILDING 9201-5N, BASEMENT U.S. DOE Y-12 PLANT}


TABLE F-1. GENERAL INSPECTION SCHEDULE

Specific Item

Fire alarm system

Telephone system

Public address (PA) system

Two-way radios

Mops, sponges

Breathing Equipment:

disposable respirators, cartridges

Protective Clothing: Tyvex suits, gloves, and booties

Fire extinguishers

Eyewash

Face shields and extra protective eye glasses Emergency shower
Types of Problems

Power failure

Power failure, cut lines

Power failure, speakers

Transmitter or receiver, batteries

Out of stock

Out of stock, exhausted

canisters, leaks, tears, rips

Out of stock, holes, rips, tears

Missing, recharge needed, wrong type

Water pressure, leaking, and drainage

Broken, dirty equipment, out of stock

Water pressure, leaking, drainage
Frequency of Inspection

Annually

As used

Daily

As used

Weekly

As used

Weekly

Weekly

Weekly

As used

Monthly 
TABLE F-2. CONTAINER STORAGE AREA INSPECTION SCHEDULE

Specific Item

Container placement

Sealing of containers

Labeling of containers

Container structural integrity

Building integrity

Floors or bases

Danger signs

Loading and unloading areas
Types of Problems

Aisle space

Open lids

Improper identification, date missing

Corrosion, leakage, structural defects

Damage, sagging, leaking

Cracks, deterioration, spalling in concrete, wet spots

Damaged, missing, or illegible signs

Spills and leaks
Frequency of Inspection

Weekly

Weekly

Weekly

Weekly

Weekly

Weekly

Weekly

As used 


\section{TABLE F-3. DAILY INSPECTION LOG SHEET FOR PRODUCTION ASSOCIATED UNITS}

Unit inspected (circle one):

Inspector's Signature:
9206

$$
9212
$$

$9720-12$

Cyanide Treatment Unit

Date:

Time:

\begin{tabular}{|c|c|c|c|}
\hline General Inspection Items & Types of Problems & $\begin{array}{c}V=\text { Acceptable } \\
X=\text { Unacceptable } \\
\text { NA }=\text { Not Applicable }\end{array}$ & $\begin{array}{c}\text { Observations, } \\
\text { Date and Nature of Repairs, Remedial } \\
\text { Action }\end{array}$ \\
\hline Telephone system (as used) & Power failure, cut lines & & \\
\hline Public address (PA) system & Power failure, speakers & & \\
\hline Two-way radios (as used) & Transmitter or receiver, batteries & & \\
\hline $\begin{array}{l}\text { Breathing equipment: disposable respirators, } \\
\text { cartridges }\end{array}$ & $\begin{array}{l}\text { Out of stock, exhausted canisters, } \\
\text { leaks, tears, rips }\end{array}$ & & \\
\hline Face shields, and extra protective eye glasses & $\begin{array}{l}\text { Broken, dirty equipment, out of } \\
\text { stock }\end{array}$ & & \\
\hline Container Inspection Items & Types of Problems & $\begin{array}{c}\sqrt{ }=\text { Acceptable } \\
\mathrm{X}=\text { Unacceptable } \\
\mathbb{N A}=\text { Not Applicable }\end{array}$ & $\begin{array}{l}\text { Observations, } \\
\text { Date and Nature of Repairs, Remedial } \\
\text { Action }\end{array}$ \\
\hline Loading and unloading areas (as used) & Spills and leaks & & \\
\hline \multicolumn{4}{|l|}{ Additional Comments: } \\
\hline
\end{tabular}




\section{TABLE F-4. WEEKLY INSPECTION LOG SHEET FOR PRODUCTION ASSOCIATED UNITS}

Unit inspected (circle one): Inspector's Signature:
9206

9212
$9720-12$

Cyanide Treatment Unit

\begin{tabular}{|c|c|c|c|}
\hline General Inspection Items & Types of Problems & $\begin{array}{c}v=\text { Acceptable } \\
X=\text { Unacceptable } \\
\text { NA }=\text { Not Applicable }\end{array}$ & $\begin{array}{c}\text { Observations, Date and Nature of Repairs, } \\
\text { Remedial Action }\end{array}$ \\
\hline Fire alarm system (annually) & Power failure & & \\
\hline Mops, sponges & Out of stock & & \\
\hline Protective clothing: suits, gloves, booties & Out of stock, inoperative, holes, rips, tears & & \\
\hline Fire extinguishers & Missing, recharge needed, wrong type & & \\
\hline Eyewash & Water pressure, leaking, drainage & & \\
\hline Emergency shower (monthly) & Water pressure, leaking, drainage & & \\
\hline Container Inspection Items & Types of Problems & $\begin{array}{c}\sqrt{ }=\text { Acceptable } \\
X=\text { Unacceptable } \\
\text { NA }=\text { Not Applicable }\end{array}$ & $\begin{array}{l}\text { Observations, Date and Nature of Repairs, } \\
\text { Remedial Action }\end{array}$ \\
\hline Container placement and stacking & Aisle space, height of stacks & & \\
\hline Sealing of containers & Open containers & & \\
\hline Labeling of containers & $\begin{array}{l}\text { Improper identification, storage or } \\
\text { accumulation start date missing }\end{array}$ & & \\
\hline Container integrity & Corrosion, leakage, structural defects & & \\
\hline Building integrity & Building is damaged, sagging, or leaking & & \\
\hline Floors or bases & $\begin{array}{l}\text { Cracks, deterioration, spalling in concrete, } \\
\text { wet spots }\end{array}$ & & \\
\hline Danger signs & $\begin{array}{l}\text { Damaged or missing, illegible signs (one } \\
\text { needed on each approach) }\end{array}$ & & \\
\hline
\end{tabular}




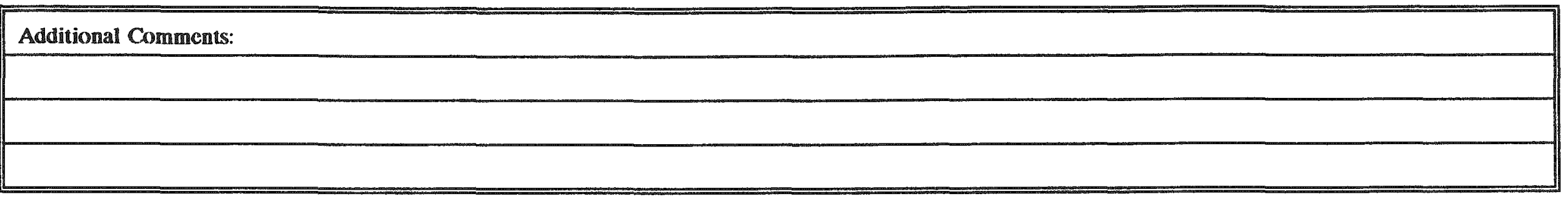

F-2-3 


\section{APPENDIX H-1}

\section{FACILITY SUPERVISOR JOB DESCRIPTION \\ (For Environmental Activities Only)}

\section{Position Title: Facility Supervisor (Team Leader for Cyanide Treatment Unit)}

Basic Function of Position: Provide technical support for waste management operations.

Major Environmental Duties and Responsibilities:

- Supervises technicians and operators in all aspects of operation of the facility, including loading, unloading, sampling, storage, inspections, maintenance, and emergency response.

- Inspects RCRA waste treatment and storage tank areas, tanks, dikes, transfer areas, piping, pumps, valves, and waste handling equipment.

- Inspects emergency response equipment including fire extinguishers, communications and alarm facilities, and spill cleanup equipment.

- Initiates appropriate remedial actions for spills, leaks, or defective equipment and ensures timely completion of remedial actions.

- Responsible for the recording of all inspections, remedial actions and their completion and maintains a file of all inspections, logs, and records.

- Works with technicians to identify, sample, and pack drums.

- Schedules all facility maintenance and oversees maintenance activities to ensure that proper procedures and safety precautions are followed, and no spill, fire, other release, or contamination of the facility, personnel, or the environment occurs.

\section{Formal Education Required:}

- High school diploma and 3 years of facility experience.

Specialized Knowledge or Training:

- 24-hour OSHA/SARA Training - one time only

- 8-hour OSHA/SARA Refresher - annual

- RCRA Training - annual

- Criticality Safety - biennial

- Hazard Communication - annual

- Radiation Protection - biennial

- Fire Protection - one time only

- Security Program - annual

- Emergency Preparedness - annual

- Respiratory Training - annual 


\section{APPENDIX H-1 (Continued)}

\section{TECHNICIAN JOB DESCRIPTION}

(For Environmental Activities Only)

\section{Position Title: Technician (Electroplater for Cyanide Treatment Unit)}

Basic Function of Position: Provides routine technically related operational support for waste management operations.

\section{Major Environmental Duties and Responsibilities:}

- Inspects the containers and containment system for leaks or deterioration caused by corrosion or other factors, and material handling equipment.

- Inspects emergency response equipment including fire extinguishers, communications and alarm equipment, and spill cleanup equipment.

- Records inspection activity on inspection log and maintains a file of logs and records.

- Notifies Facility Supervisor of observed problems at the facility, emergency situations, and the need for contingency and/or remedial action.

- Verifies waste stream identification and documentation.

- Takes sample of waste streams from containers as required for analysis.

- Assures proper handling and storage of wastes, including separation of incompatible wastes, prevention of their contact or mixing, and separate storage of ignitables and reactives.

- Assures proper documentation of waste stream identification and storage location, inventory, inflow and outflow.

- Assists in immediate response to spills and notifies the PSS office and Staff Engineer.

Formal Education Required:

- Bachelors degree in engineering and/or equivalent education and/or experience.

Specialized Knowledge or Training:

- 24-hour OSHA/SARA Training - one time only

- 8-hour OSHA/SARA Refresher - annual

- RCRA Training - annual

- Criticality Safety - biennial

- Hazard Communication - annual

- Radiation Protection - biennial

- Fire Protection - one time only

- Security Program - annual

- Emergency Preparedness - annual

- Respiratory Training - annual 
APPENDIX H-1 (Continued)

\section{HOURLY WORKER JOB DESCRIPTION \\ (For Environmental Activities Only)}

Position Title: Hourly Worker, Waste Management Organization

Basic Function of Position: Under direct supervision, performs daily operational activities at waste management facilities including the transferring of wastes and handling of waste containers.

Major Environmental Duties and Responsibilities:

- Assists with operations involving hazardous waste treatment and storage.

- Moves full and empty containers as required.

- Assists in emergency spill response and cleanup and fire control, and takes other emergency action in accordance with established procedures.

- Performs duties under the direction of the technician present.

Formal Education Required:

- No minimum requirements.

Specialized Knowledge or Training:

- Requires completion of waste management training program. Additionally, requires individuals to be designated respirator wearers.

- 24-hour OSHA/SARA Training - one time only

- 8-hour OSHA/SARA Refresher - annual

- RCRA Training - annual

- Criticality Safety - biennial

- Hazard Communication - annual

- Radiation Protection - biennial

- Fire Protection - annual

- Security Program - annual

- Emergency Preparedness - annual

- Respiratory Training - annual

- Fork-lift Truck Drivers Training - every 3 years 


\section{APPENDIX H-1 (Continued) \\ CHEMICAL OPERATOR JOB DESCRIPTION \\ (For Environmental Activities Only)}

\section{Position Title: Chemical Operator (Electroplater for Cyanide Treatment Unit)}

Basic Function of Position: Follows established methods and techniques in performing a single or sequence of operations required in various waste treatment processes associated with the chemical and physical change of materials. Adjusts, regulates, controls, and operates a wide variety of standard and specialized waste treatment processes and associated equipment. Uses various measuring and recording equipment and devices. Maintains detail records of process parameters.

Major Environmental Duties and Responsibilities:

- Moves full and empty containers as required.

- Performs duties under the direction of the Facility Supervisor present.

- Must be able to perform basic arithmetic calculations including fractions and decimals.

- Performs single or sequence of operations required to transfer and/or treat various wastes.

- Monitors controls and processes to assure proper operation, transfer, and/or treatment.

- Maintains necessary operating records.

Formal Education Required:

- High School diploma and/or equivalent education and/or experience.

Specialized Knowledge or Training:

- 24-hour OSHA/SARA Training - one time only

- 8-hour OSHA/SARA Refresher - annual

- RCRA Training - annual

- Criticality Safety - biennial

- Hazard Communication - annual

- Radiation Protection - biennial

- Fire Protection - one time only

- Security Program - annual (as needed)

- Emergency Preparedness - annual

- Respiratory Training - annual (as needed) 


\section{APPENDIX H-1 (Continued)}

\section{TRAINING MANAGER JOB DESCRIPTION \\ (For Environmental Activities Only)}

Position Title: Training Manager

Basic Function of Position: Manage the training program of the organization and assure that the required training for compliance with RCRA is implemented, and documented.

Major Environmental Duties and Responsibilities:

- Organized and direct the function of training in a cost-effective manner to assure compliance with the training requirements of RCRA.

- Supervise any of the training positions reporting to the training manager. These positions may include training supervisors, instructional technologists, curriculum developers, training coordinators, training administrators, training instructors, on-the-job trainers, and/or subject matter experts.

- Analyze resource needs and create section training budget based on all requirements including RCRA.

- Develop long-range training plans for qualification of personnel in assigned section.

- Interface with management, DOE, and other agencies to determine training requirements including RCRA.

- Ensure all training meets DOE and Y-12 Plant standards as well as RCRA requirements including assuring that the required annual RCRA training is performed and documented.

- Develop long-range training plans for training staff to assure compliance with RCRA.

- As applicable to RCRA compliance, oversee training contracts to ensure deliverables meet DOE and Y-12 Plant standards of training.

Formal Education Required:

- Bachelors degree with formal training in adult learning, training analysis, design, development, implementation, evaluation, or equivalent work experience in a training function which demonstrates skills and knowledge have been acquired and utilized.

Specialized Knowledge or Training:

- Successful completion of the DOE Basic Instructor course (Train-the-Trainer)

- Successful completion of the Supervisor's On-The-Job Training course.

- 24-hour OSHA/SARA Training - one time only

- Criticality Safety - biennial

- Hazard Communication - annual

- Radiation Protection - biennial

- Fire Protection - annual

- Emergency Preparedness - annual 
APPENDIX H-1 (Continued)

\section{TRAINING ADMINISTRATOR JOB DESCRIPTION \\ (For Environmental Activities Only)}

Position Title: Training Administrator

Basic Function of Position: Provide assigned division with plant oversight technical training support to assure that all training requirements are met based on RCRA.

Major Environmental Duties and Responsibilities:

- Work with other training organizations to ensure that training programs meet DOE and Y-12 Plant standards as well as comply with the RCRA training requirements. Provide written approval of acceptable programs.

- Work with other training organizations to develop long-range training plans for qualification of personnel in assigned section including annual RCRA training for the appropriate personnel.

- Interface with management, DOE, and other agencies to determine training requirements including RCRA.

- Work with other training organizations to develop long-range training plans for training staff.

- Develop training standards which will enhance the quality of training at $\mathrm{Y}-12$ including performing periodic audits to assure compliance.

- Complete any other assignments assigned by their training manager in order to assure compliance with RCRA.

Formal Education Required:

- Bachelors degree with formal training in training analysis, design, development, implementation, evaluation, or equivalent work experience in a training function which demonstrates these skills and knowledge have been acquired and utilized effectively.

- In lieu of a BS/BA degree, three years of progressively expanding responsibilities in training related work.

Specialized Knowledge or Training:

- Successful completion of the DOE Basic Instructor course (Train-the-Trainer).

- Successful completion of Radiation Protection Instructor's course.

- 24-hour OSHA/SARA Training - one time only

- 8-hour OSHA/SARA Refresher - annual

- RCRA Training - annual

- Criticality Safety - biennial

- Hazard Communication - annual

- Radiation Protection - biennial

- Fire Protection - annual

- Security Program - annual

- Emergency Preparedness - annual 
APPENDIX H-1 (Continued)

\section{TRAINING COORDINATOR JOB DESCRIPTION \\ (For Environmental Activities Only)}

\section{Position Title: Training Coordinator}

Basic Function of Position: Develop, facilitate, and implement training activities for the personnel in assigned section of the specific division

Major Environmental Duties and Responsibilities:

- In areas of subject matter experience, specifically RCRA, develop training courses using the Instructional System Development design.

- Using developed RCRA course material, instruct personnel in job required curriculum at least annually.

- Evaluate students for successful completion of RCRA training.

- In areas of subject matter experience, specifically RCRA, assist other instructors as required by the training manager in the development and delivery of course material.

- Establish and maintain all documentation of appropriate training files.

- Complete any other assignments assigned by their training manager.

Formal Education Required:

- High school diploma or equivalent.

Specialized Knowledge or Training:

- Trained in hazardous waste management procedures and regulations.

- Successful completion of the DOE Basic Instructor course (Train-the-Trainer).

- Successful completion of Radiation Protection Instructor's course.

- Criticality Safety - biennial

- RCRA Training - annual

- Hazard Communication - annual

- Radiation Protection - biennial

- Urinalysis - one time only

- Fire Protection - annual

- Security Program - annual

- Emergency Preparedness - annual

- Respiratory Training - annual 


\section{APPENDIX H-2 (Continued)}

\section{ON-THE-JOB TRAINER JOB DESCRIPTION \\ (For Environmental Activities Only)}

Position Title: On-The-Job Trainer

Basic Function of Position: Assist in the development of on-the-job training (OJT) courses, instruct personnel, evaluate trained personnel, and evaluate training.

Major Environmental Duties and Responsibilities:

- In areas of subject matter experience, specifically RCRA compliance and hazardous waste management, assist in the development of OJT courses.

- Using developed OJT course material, instruct personnel in job required curriculum for RCRA compliance and proper hazardous waste management.

- Evaluate RCRA training to ensure quality of program.

- Complete any other training assignments assigned by training manager.

Formal Education Required:

- High school diploma or equivalent.

Specialized Knowledge or Training:

- Trained in hazardous waste management procedures.

- Successful completion of the Supervisor's On-The-Job Training course.

- 24-hour OSHA/SARA Training - one time only

- 8-hour OSHA/SARA Refresher - annual

- RCRA Training - annual

- Criticality Safety - biennial

- Hazard Communication - annual

- Radiation Protection - biennial

- Fire Protection - annual

- Security Program - annual

- Emergency Preparedness - annual

- Respiratory Training - annual 


\section{DISCLAIMER}

Portions of this document may be illegible in electronic image products. Images are produced from the best available original document. 


A. K. Lee, DOE-OSTI

9731, MS-8175 